NATIONAL LABORATORY

MANAGED BY UT-BATTELLE

FOR THE DEPARTMENT OF ENERGY

\title{
Wireless for Steel Energy Efficiency Final Report
}

\section{June 2013}

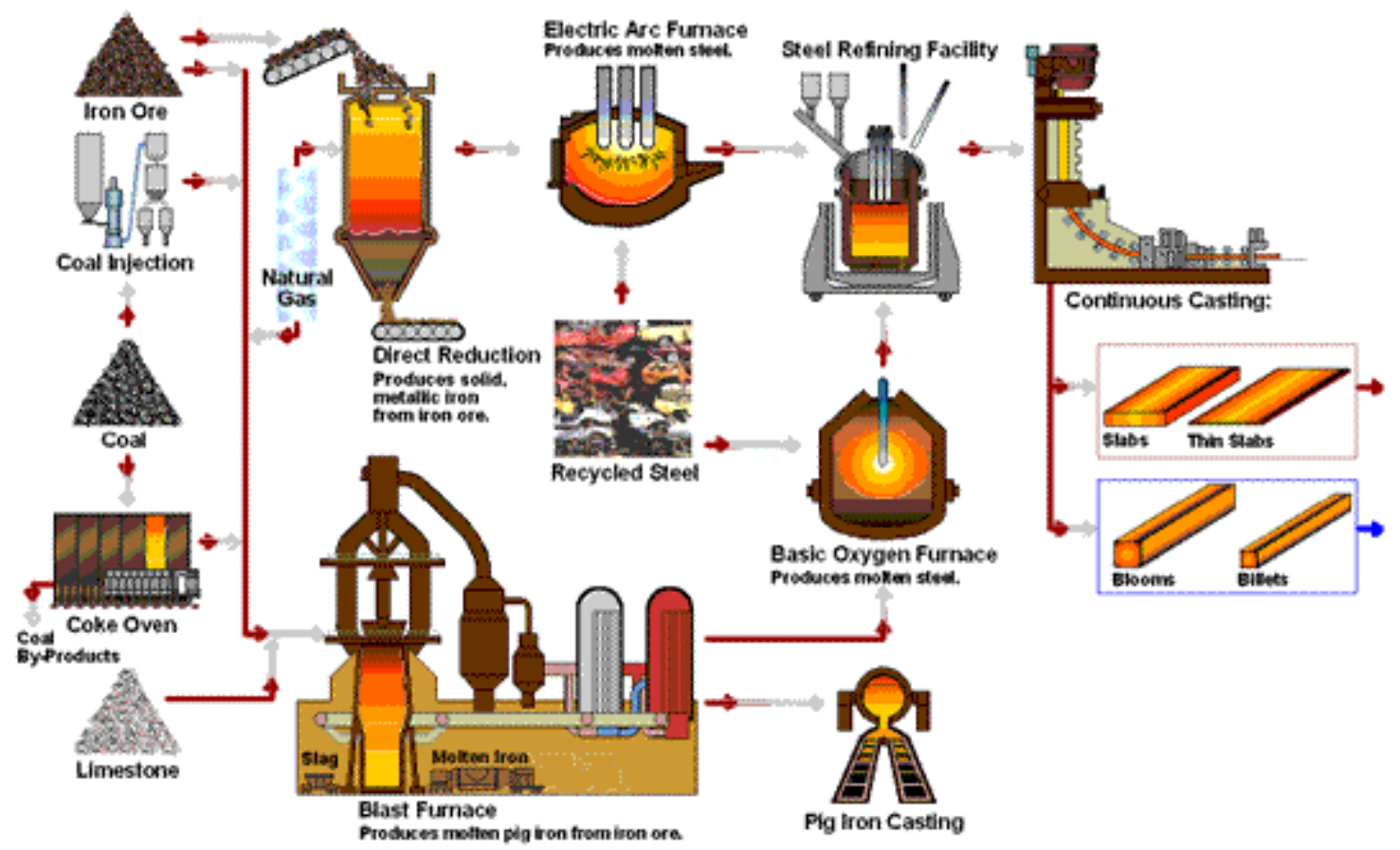

\section{Prepared by}

Glenn O. Allgood, Principal Investigator

Wayne W. Manges, Program Manager

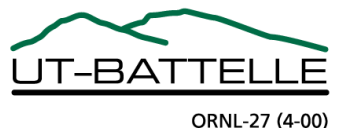


Acknowledgment: This report is based upon work supported by the U.S. Department of Energy under Award No. ED1802000.

Disclaimer: Any findings, opinions, and conclusions or recommendations expressed in this report are those of the author(s) and do not necessarily reflect the views of the Department of Energy.

\section{DOCUMENT AVAILABILITY}

Reports produced after January 1, 1996, are generally available free via the U.S. Department of Energy (DOE) Information Bridge.

Web site http://www.osti.gov/bridge

Reports produced before January 1, 1996, may be purchased by members of the public from the following source.

National Technical Information Service

5285 Port Royal Road

Springfield, VA 22161

Telephone 703-605-6000 (1-800-553-6847)

TDD 703-487-4639

Fax 703-605-6900

E-mail info@ntis.gov

Web site http://www.ntis.gov/support/ordernowabout.htm

Reports are available to DOE employees, DOE contractors, Energy Technology Data Exchange (ETDE) representatives, and International Nuclear Information System (INIS) representatives from the following source.

Office of Scientific and Technical Information

P.O. Box 62

Oak Ridge, TN 37831

Telephone 865-576-8401

Fax 865-576-5728

E-mail reports@osti.gov

Web site http://www.osti.gov/contact.html

This report was prepared as an account of work sponsored by an agency of the United States Government. Neither the United States Government nor any agency thereof, nor any of their employees, makes any warranty, express or implied, or assumes any legal liability or responsibility for the accuracy, completeness, or usefulness of any information, apparatus, product, or process disclosed, or represents that its use would not infringe privately owned rights. Reference herein to any specific commercial product, process, or service by trade name, trademark, manufacturer, or otherwise, does not necessarily constitute or imply its endorsement, recommendation, or favoring by the United States Government or any agency thereof. The views and opinions of authors expressed herein do not necessarily state or reflect those of the United States Government or any agency thereof. 
ORNL/TM-2012/449

Measurement Science \& Systems Engineering Division

\title{
Wireless for Steel Energy Efficiency Final Report
}

DOE Award No. ED1802000

Project Period 10/2009 - 09/2012

\begin{abstract}
Author(s)
Glenn O. Allgood, ORNL Principal Investigator, 865-256-3670, allgoodgo@ornl.gov Wayne W. Manges, ORNL Program Manager, 865-574-8529, mangesww@ornl.gov Joe Lake, ORNL Project Manager, 865-241-1592, lakeje@ornl.gov Mariann Sawyers, ORNL Administrative Lead, 865-576-8379, sawyersmh@ornl.gov Beverly Kay, ORNL Administrative Specialist, 865-574-5206, kayb@ornl.gov Bill Nickerson, Impact Technologies,814-404-7612, gwnickerson@ gmail.com Sam Matson, CMC Steel, 830-305-9925, Sam.Matson@CMC.com Ron Lachman, U.S. Steel, 412-273-4775, RCLachman@USS.com
\end{abstract}

Date Revised and Published: June 2013

Prepared by OAK RIDGE NATIONAL LABORATORY

Oak Ridge, Tennessee 37831-6283

managed by

UT-BATTELLE, LLC

for the

U.S. DEPARTMENT OF ENERGY

under contract DE-AC05-00OR22725 



\section{Contents}

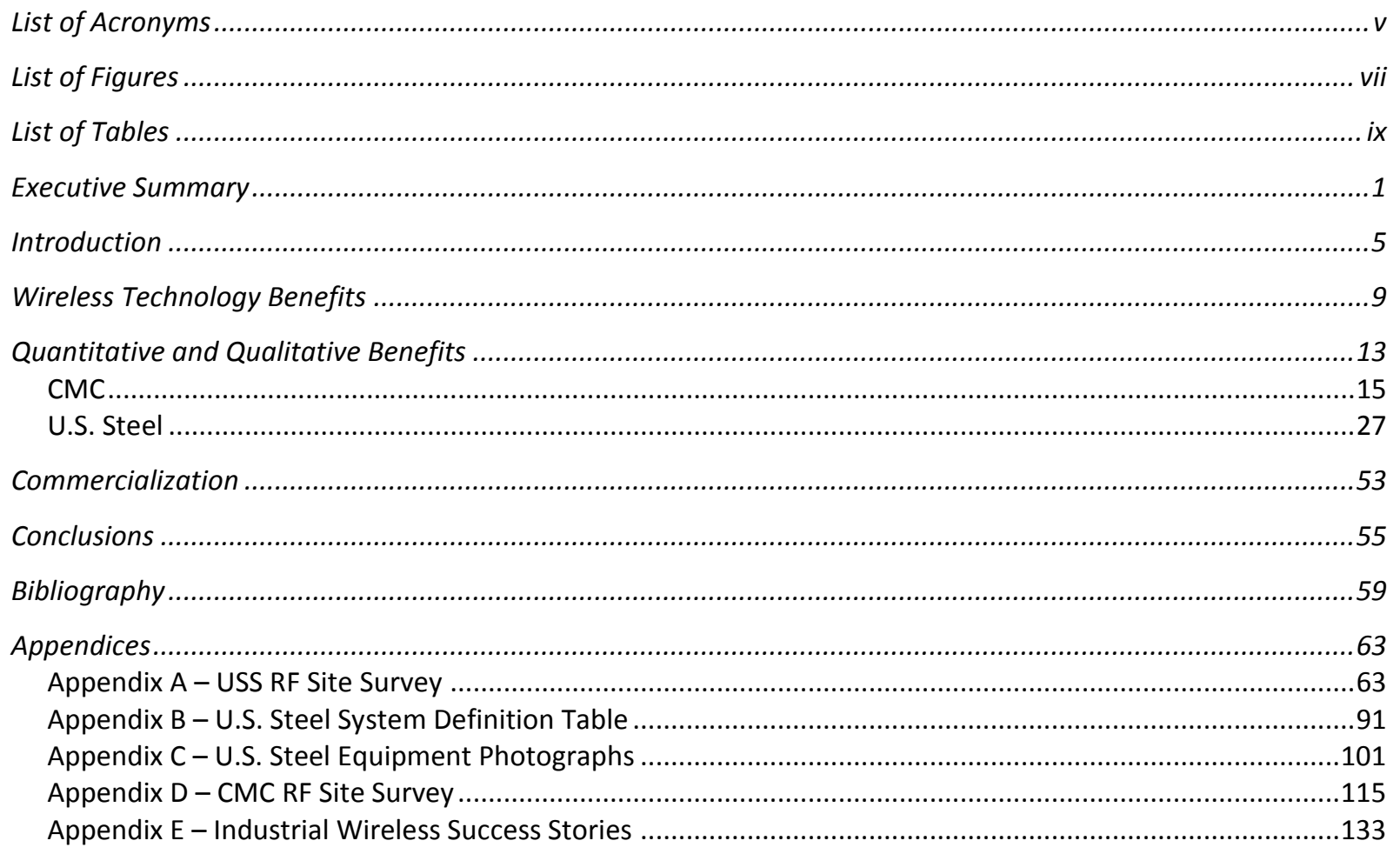




\section{List of Acronyms}

\begin{tabular}{ll} 
AMO & Advanced Manufacturing Office \\
Andrews & Andrews Industrial Controls Inc. \\
BOP & Basic Oxygen Process \\
CMC & Commercial Metals Company \\
COTS & commercial-off-the-shelf \\
DOE & U.S. Department of Energy \\
EAF & electric arc furnace \\
EDA & Enterprise Derivative Analysis \\
E.T. & Edgar Thomson \\
GUI & graphical user interface \\
ISM & Industrial, Scientific, and Medical \\
IT & information technology \\
ITP & Industrial Technologies Program \\
LAN & local area network \\
LMS & ladle metallurgy station \\
LSQ & least square quadratic \\
NAS & National Academy of Sciences \\
ORNL & Oak Ridge National Laboratory \\
OIT & Office of Industrial Technology \\
PLC & programmable logic controller \\
RF & radio frequency \\
ROI & return on investment \\
SCADA & supervisory control and data acquisition \\
SMA & Steel Manufacturers Association \\
SQL & Structured Query Language \\
U.S. Steel & United States Steel \\
VPN & virtual private network \\
WirelessHART & wireless sensor networking technology based on the Highway Addressable Remote \\
& Transducer Protocol \\
\hline
\end{tabular}




\section{List of Figures}

Fig. 1. Steelmaking flow lines showing electric-arc and blast furnace processes. .................................2

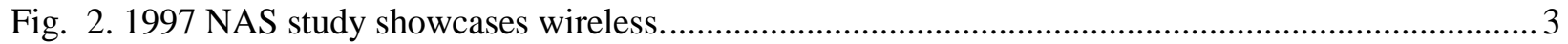

Fig. 3. Due diligence process for wireless sensor network in steel facilities...................................... 6

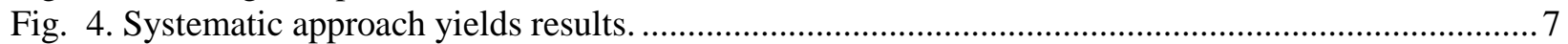

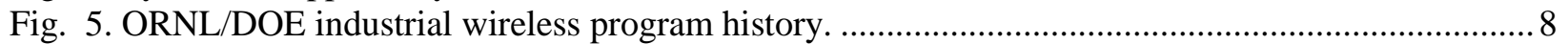

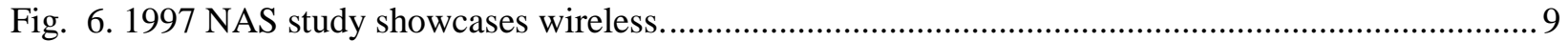

Fig. 7. ORNL/DOE industrial wireless program workshops pulled together key stakeholders. ............... 10

Fig. 8. Industrial wireless technology - from impossible to trivial. ........................................................ 11

Fig. 9. Steelmaking flow lines showing electric-arc and blast furnace processes. .................................. 13

Fig. 10. Topological view of placement of the heat trace sensors representing the bulk of sensors deployed in $\mathrm{CMC}$ wireless energy monitoring system............................................................. 16

Fig. 11. Heat loss trend projections obtained from the CMC wireless energy monitoring system............ 17

Fig. 12. A notional view of the wireless energy monitoring system deployed at CMC Steel South Carolina. The important feature is the isolation through the firewall of the new wireless sensor network and CMC's existing process network.

Fig. 13. System architectural view of the CMC wireless energy monitoring system deployed at CMC Steel South Carolina, showing detailed sensors, gateways, and connectivity.

Fig. 14. Instantaneous energy losses through the EAF off-gas water-cooled ductwork for three back-to-back batches (heats) of steel.

Fig. 15. D1 duct losses are higher in magnitude when more charge carbon is added with the scrap.

Fig. 16. Average electrical energy consumption (KWH per scrap ton) and totalized off-gas energy losses (equivalent KWH per scrap ton) for increasing amounts of charge carbon for the 3 months of operation between March and May 2012 ..............................................2 23

Fig. 17. Aerial view shows the layout of the CMC EAF mill in Cayce, South Carolina..........................25

Fig. 18. Integration strategy for energy efficiency wireless sensor network. ........................................29

Fig. 19. Aerial view of wireless monitoring system installation at E.T. Plant......................................37

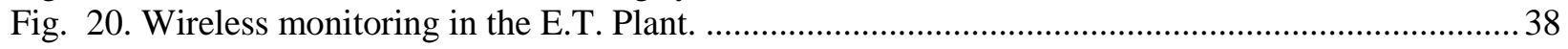

Fig. 21. Architecture overview of wireless monitoring system at E.T. Plant. ....................................... 39

Fig. 22. Installed network architecture and IT integration for wireless monitoring system at E.T. Plant.

Fig. 23. Excerpt of Andrews' drawing of main radio unit showing extent of U.S. Steel personnel installation and configuration responsibility.

Fig. 24. Initial measurements of sensors in Davey 1 preheater in BOP ............................................. 45

Fig. 25. Initial measurements of sensors in Davey 3 preheater in BOP ..............................................46

Fig. 26. Initial measurements of coke oven gas sensors in Boiler \#3 in \#2 Powerhouse........................... 47

Fig. 27. Initial measurements of blast furnace gas sensors in Boiler \#3 in \#2 Powerhouse. ......................48

Fig. 28. Initial measurements of economizer and preheater temperature sensors in Boiler \#3 in \#2 Powerhouse.

Fig. 29. The "canyons of metal" environment typical to steel-making facilities - a wireless challenge. 


\section{List of Tables}

Table 1. Subset of system definition table (Revision 1) from Appendix B of technical specification in solicitation.....

Table 2. Installed sensors as represented in subset of system definition table (from Appendix B of solicitation)

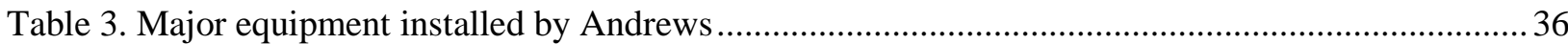

Table 4. Operational ranges of sensors in wireless monitoring system at E.T. Plant .............................. 40

Table 5. System Definition Table (Revision 1) from Appendix B of technical specification in solicitation

Table 6. Photographs of all Equipment Installed by Andrews at E.T. Plant........................................ 101 


\section{Executive Summary}

Oak Ridge National Laboratory (ORNL) has worked for many years with the U.S. Department of Energy's (DOE's) Advanced Manufacturing Office (AMO) and its predecessors, Industrial Technologies Program (ITP) and the Office of Industrial Technology (OIT) to investigate opportunities to realize the potential energy savings identified in the academic studies published over the years. The team from ORNL gratefully acknowledges the support of AMO in the successful completion of this demonstration project.

This initiative was intended to demonstrate the energy savings and operational benefits of new sensor and control deployments enabled by the effective use of wireless sensor networks in a steel manufacturing facility. The implementation in two separate facilities, one integrated mill and one electric arc furnace (EAF)-based mill, offered a unique opportunity for overcoming some well entrenched resistance to wireless. Many facilities, including the two selected, had seen past deployments of wireless technology fail catastrophically in the harsh environments common in these facilities.

A team from ORNL worked with DOE program managers, end users, and end-user representatives to identify specific steelmaking processes that could benefit (energy and emission savings) from the deployment of advanced wireless technologies, the focus being on establishing a 'business and economic advantage.' The process list was then used to identify companies that would be approached to serve as the deployment venue. Once a site was selected, representatives from each site worked with the ORNL Team using a "value-derivative" process to develop a deployment strategy for their particular manufacturing process that would be most amenable to the addition of wireless technology. Finally, the ORNL team and a selected vendor in collaboration with the particular operational site deployed and integrated the appropriate components and subsystems with the greatest opportunity to demonstrate the expected energy savings.

ORNL, working with United States Steel (U.S. Steel) at their Edgar Thomson (E.T.) Works in Pittsburgh, Pennsylvania, and with Commercial Metals Company (CMC) at their Cayce, South Carolina, mill, developed the approach detailed in this report. The team used this approach for the analysis and implementation that resulted in engineered solutions addressing the needs of the user, the harsh environment considerations necessary for successful deployments, and the vendors' considerations around ensured success and control of life-cycle costs. The deployment demonstrated the appropriate system stability, reliability, resiliency, and overall availability necessary for energy efficiency monitoring. The resulting data have been used by the end user to improve controls, processes, and operations. The data retrieved from the monitoring of the integrated wireless sensor network show that the reliability, latency, security, and throughput have met all operational requirements and have exceeded CMC expectations. This will be an encouragement to those committed to more wide-scale deployment of a new generation of wireless sensors for use in harsh industrial environments.

The two sites selected for deployment allowed the demonstration of energy efficiency gains at an "integrated mill" of U.S. Steel and a "mini mill" of CMC. Fig. 1 illustrates the two processes and how they are related. The installations and operation of the wireless sensor networks went smoothly at both sites. The wireless sensor vendors selected (based on a rigorous requirements development and evaluation process) were different for the two sites but both were "industrial-grade" wireless solutions suitable for each of the harsh environments. Both installations proved stable over the year-long burn-in process, and both systems have provided qualified data for the plant operators to use in making decisions regarding operating efficiency gains achievable at their respective site. This is an important attribute for any newly deployed system at either site. Without establishing the pedigree and confidence in the system, a commercial entity will be hesitant to change their business or operational conduct. 
The wireless sensor system installed achieved levels of availability expected for production use, greater than $95 \%$ data availability. The data provided by the system have allowed CMC Steel to consider new options in achieving improved efficiency at their site. The CMC site has taken aggressive action and subsequently realized significant energy savings projected to provide a return on investment (ROI) payback in less than a year. The Enterprise Derivative Analysis (EDA) clearly indicated where the "sweet spots" were and guided the users in their decision to proceed. CMC has agreed that further deployment of wireless technology would be forthcoming with subsequent continued improvements in energy efficiency.

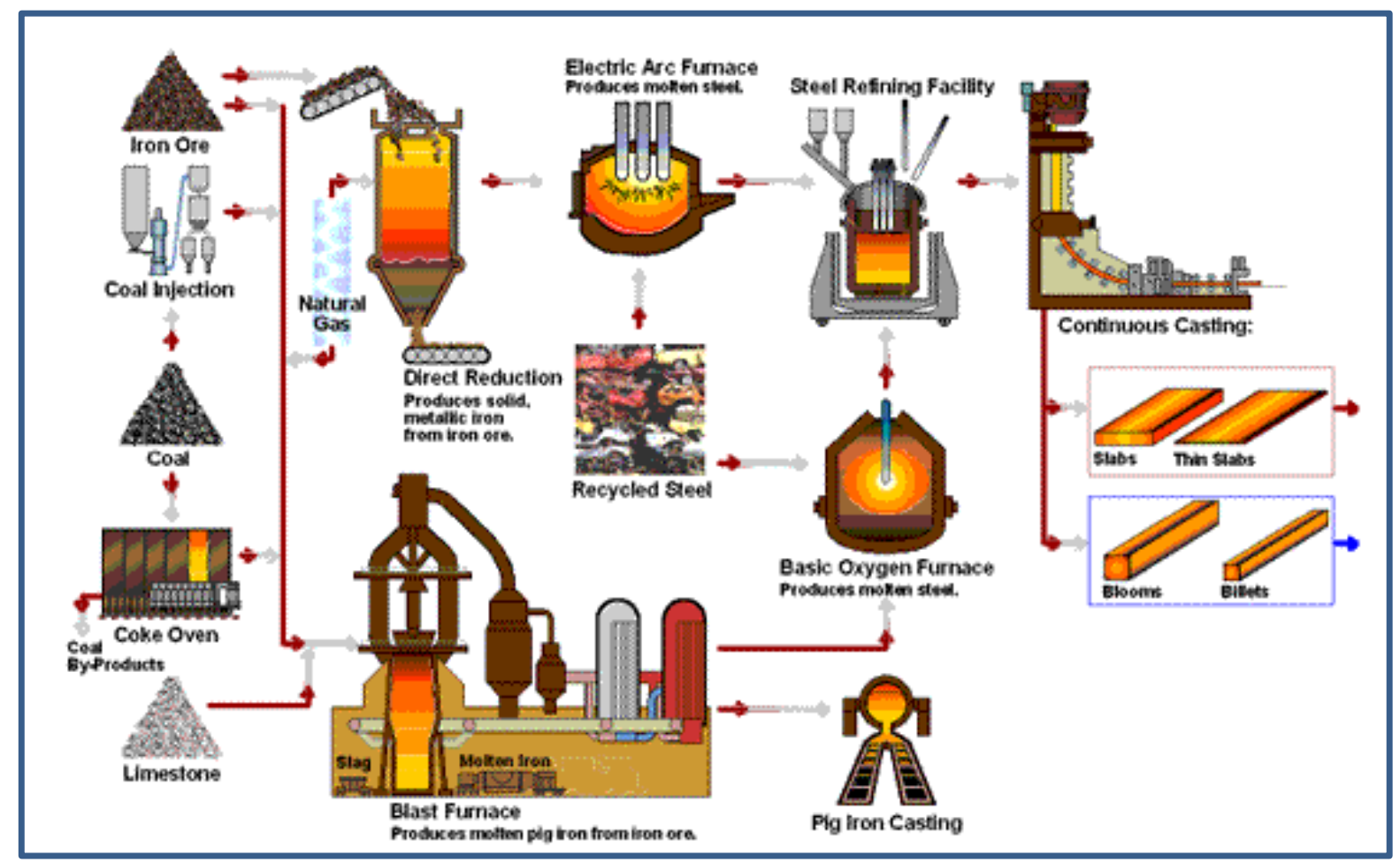

Fig. 1. Steelmaking flow lines showing electric-arc and blast furnace processes.

An important milestone occurred in 1997 when a National Academy of Sciences (NAS) study (Fig. 2) documented that significant amounts of energy could be saved with the deployment of robust, secure wireless sensors for better energy awareness and faster response to upsets. 


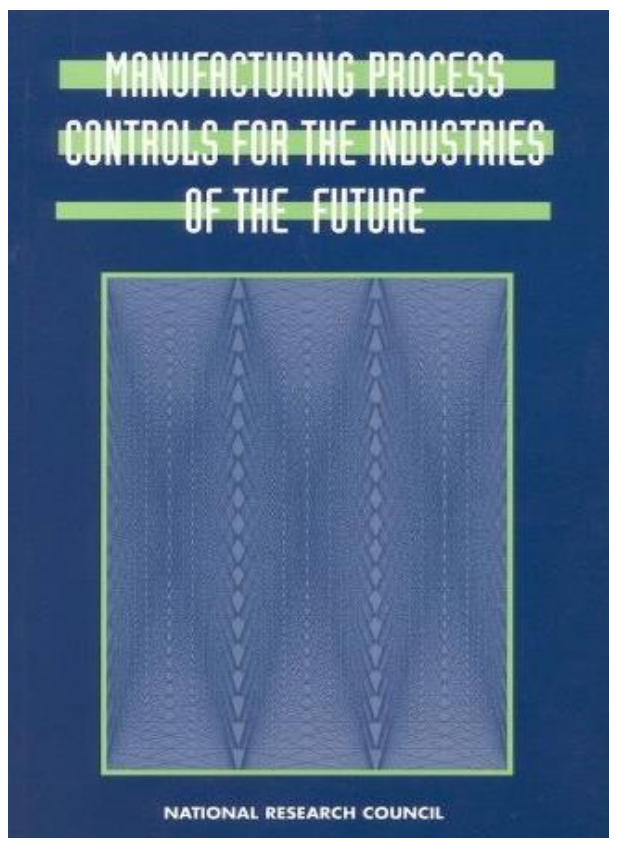

Fig. 2.1997 NAS study showcases wireless.

The deployment for this wireless steel demonstration project was to illustrate that wireless had "come of age" and was "ready for prime time" deployment as a critical enabler for energy efficiency in harsh environments.

The wireless sensor systems installed at both sites achieved levels of availability expected for production use, greater than $95 \%$ data availability. The data provided by the systems have allowed each company to consider new options in achieving improved efficiency at their site. The CMC site has taken aggressive action and has subsequently realized significant energy savings projected to provide a return on investment payback in less than a year. The Enterprise Derivative Analysis (EDA) clearly indicated where the "sweet spots" were and guided the users in their decisions to proceed. Both end users have agreed that further deployments of wireless technology would be forthcoming with subsequent continued improvements in energy efficiency.

The system installed by Andrews Industrial Controls, Inc. (Andrews) at U.S. Steel addressed both high and moderate priority levels. The system provided measurements (e.g. temperature and pressure) in addition to what was requested as well as calculations. The subject matter experts at U.S. Steel are continuing to use the data provided by this energy-monitoring system to adjust process parameters in new ways to improve energy efficiency.

Wunderlich - Malec Systems, Inc. (WM) installed a wireless sensor network at CMC based on the WirelessHART® protocol (international standard IEC 62591). The monitoring system provided displays and historical archives of critical energy use data for analysis by the subject matter experts at CMC. The overall assessment of the deployed CMC wireless energy monitoring system is that it exceeded all operational expectations and through a campaign to improved charge carbon measurement $\mathrm{CMC}$ can improve process efficiency by reducing electrical and charge carbon consumption while reducing steel batch processing times. Electrical energy consumption could be reduced by 5 to $10 \mathrm{KWH}$ per scrap ton ( 6 to $11 \mathrm{KWH}$ per cast ton) and charge carbon consumption by $500 \mathrm{lbs}$. per batch equaling $20 \mathrm{KWH}$ per scrap ton reduction ( $22 \mathrm{KWH}$ per cast ton). With these changes it is estimated that a savings of $\$ 1$ per cast ton (\$750,000 annually) can be realized by CMC Steel South Carolina. 


\section{Introduction}

This project is focused on leveraging government and industry collaborative investments made in steel manufacturing and industrial-capable wireless sensor networks over the last 15 years. In recent years, U.S. Department of Energy (DOE) and ORNL have worked with industrial suppliers on the development and deployment of wireless technology for harsh industrial environments, aimed at reducing the energy intensity of heavy industry through the improved monitoring and control enabled by the new technology. Goals included demonstrating energy savings, emission reduction, and enhanced business effectiveness enabled by advances that are ready to be deployed under this program. The implementation in two separate facilities, one integrated mill and one EAF-based mill, offered a unique opportunity for overcoming some well entrenched resistance to wireless. Many facilities, including the two selected, had seen past deployments of wireless technology fail catastrophically in the harsh environments common in these facilities.

A team from ORNL worked with DOE program managers, end users, and end-user representatives to identify specific steelmaking processes that could benefit (energy and emission savings) from the deployment of advanced wireless technologies, the focus being on establishing a 'business and economic advantage.' The process list was then used to identify companies that would be approached to serve as the deployment venue. Once a site was selected, representatives from each site worked with the ORNL Team using a "value-derivative" process to develop a deployment strategy for their particular manufacturing process that would be most amenable to the addition of wireless technology. Finally, the ORNL team and a selected vendor in collaboration with the particular operational site deployed and integrated the appropriate components and subsystems with the greatest opportunity to demonstrate the expected energy savings.

ORNL, working with U.S. Steel at their E.T. Works in Pittsburgh, Pennsylvania, and with CMC at their Cayce, South Carolina, mill, developed the approach detailed in this report. The team used this approach for the analysis and implementation that resulted in engineered solutions addressing the needs of the user, the harsh environment considerations necessary for successful deployments, and the vendors' considerations around ensured success and control of life-cycle costs. The deployment demonstrated the appropriate system stability, reliability, resiliency, and overall availability necessary for energy efficiency monitoring. The resulting data have been used by the end user to improve controls, processes, and operations. The data retrieved from the monitoring of the integrated wireless sensor network show that the reliability, latency, security, and throughput have met all operational requirements and have exceeded CMC expectations. This will be an encouragement to those committed to more wide-scale deployment of a new generation of wireless sensors for use in harsh industrial environments.

Our team exercised robust processes based on the Operations Research background of our members. The process included a rigorous due diligence approach for site selection, vendor selection, and acceptance testing. Fig. 3 details major steps in this process. A document developed in support of the procurement process of the wireless sensor network is included in the Appendices. 


\section{Due Diligence Process}

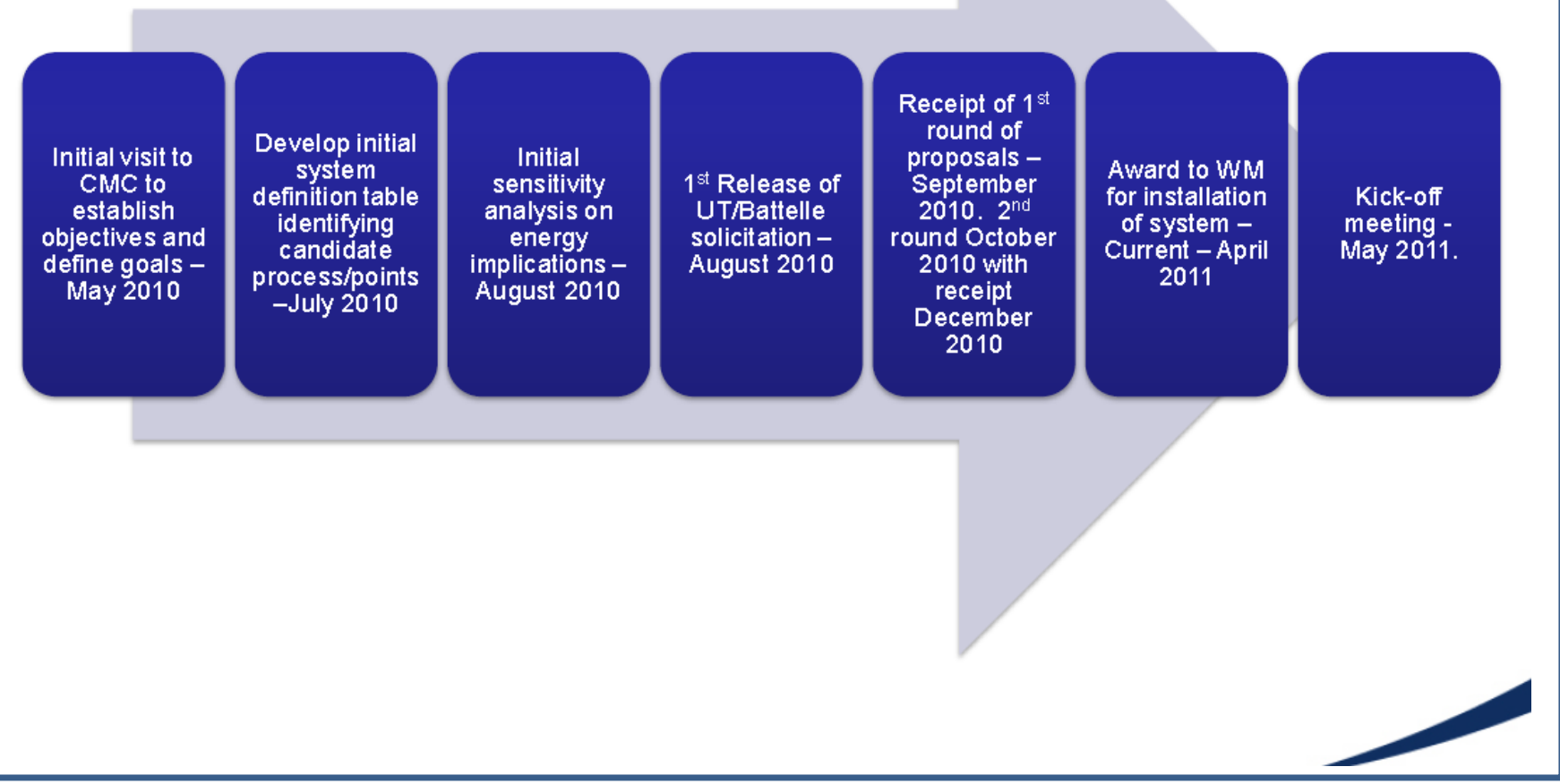

Fig. 3. Due diligence process for wireless sensor network in steel facilities.

The wireless energy monitoring system has provided CMC continuous readings of the energy losses from the EAF steel melting process. The wireless water temperatures have made it possible to calculate the energy transferred from the EAF waste gas to the water-cooling system. The instantaneous energy losses correlate well with the rate of chemical energy addition and the amount of carbon added to the furnace. The energy loss information provided by the wireless energy monitoring system has pointed CMC toward developing a more reliable and precise system for measuring the carbon added to the EAF.

Installing the wireless instrumentation eliminated the costs of (1) conduit and signal wiring to the programmable logic controller (PLC), (2) input/output (I/O) cards in the PLC to accept the new signals, and (3) future instrumentation in the same area of the plant where additional wireless instrumentation can be installed.

ORNL, working with the two steel manufacturers, studied their processes to identify how to most effectively demonstrate that wireless could be used to save energy. The approach would provide credible estimates of expected savings and, once the wireless sensor networks were deployed, demonstrate the viability of the systematic approach undertaken. Note that the systematic approach illustrated in Fig. 4 requires all three activities for demonstrable, repeatable success: 
1) Infrastructure - provides reliable, secure wireless telemetry with embedded intelligence, all suitable for the harsh environments of this industry. This "IT for Manufacturing" approach referenced in Fig. 4 leverages the work done over many years by the information technology (IT) community, providing actionable information for their respective corporate entities;

2) Energy Analytics - provides the intermediate mathematical operations required for the next step. Models are used to validate sensor readings, fuse values from multi-modal sensors, and assess "mission readiness" for the equipment in place; and

3) EDA - provides the differential equations and relevant solutions around operating points to predict achievable optimizations available.

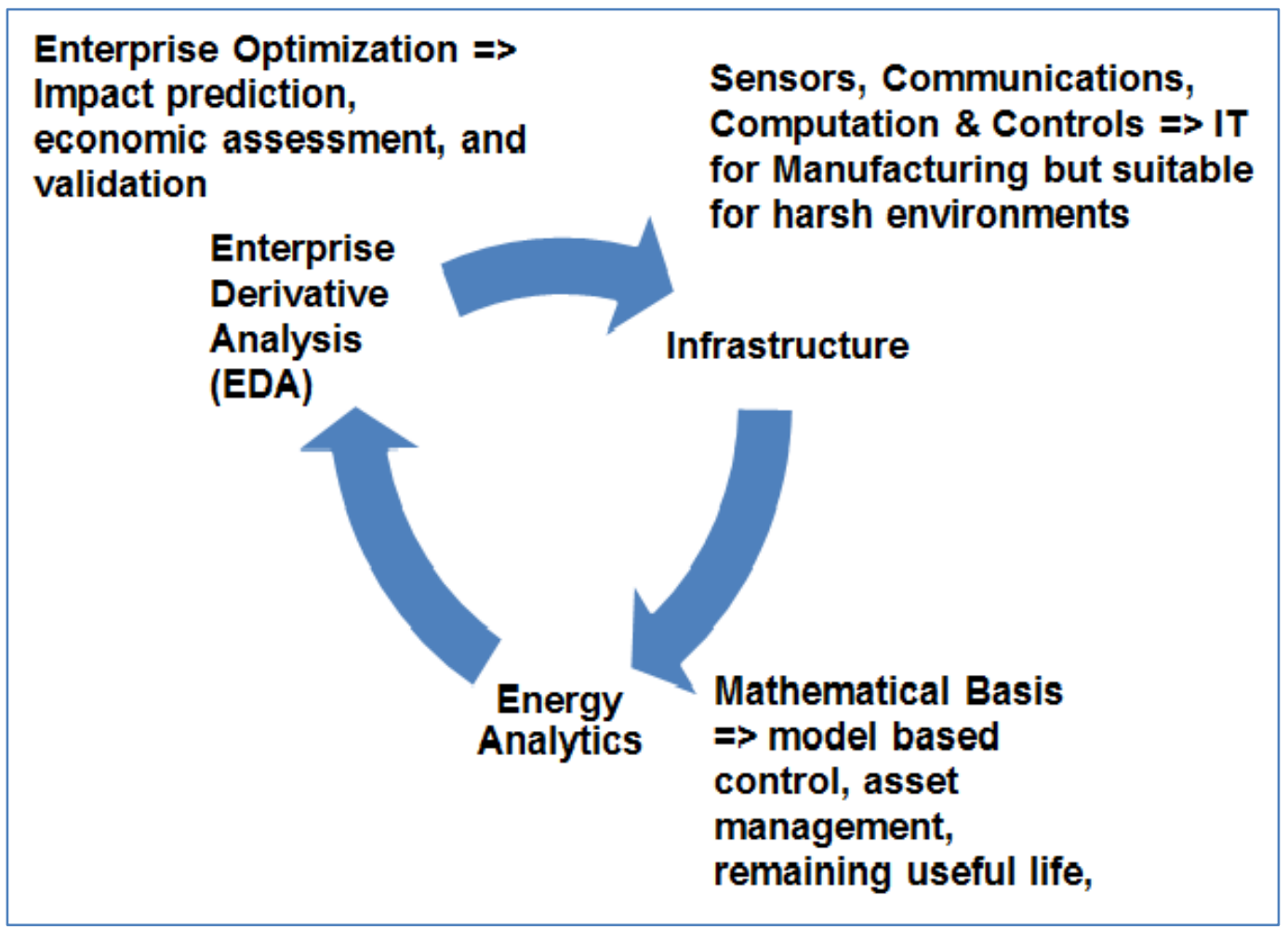

Fig. 4. Systematic approach yields results.

The EDA is based on a calculation of Enterprise Derivative (ED) sensitivity parameters. Process gains (production, efficiency, energy, and quality) are estimated as incremental changes from the operating point. The mathematical formulation for any process gain, $f$,

$$
f(x)=f\left(x_{0}\right)+f^{\prime}\left(x_{0}\right)\left(x-x_{0}\right)+. .+\frac{f^{n}\left(x_{0}\right)\left(x-x_{0}\right)^{n}}{n !}+R n
$$

where $\boldsymbol{X}_{\boldsymbol{o}}$ is the current plant operating point and $\boldsymbol{R} \boldsymbol{n}$ is a remainder and is ignored in this formulation. In this expansion, we are only interested in the first term, $\boldsymbol{f}^{\prime}\left(\boldsymbol{x}_{\boldsymbol{o}}\right)$, which is the generalized differential approximation or ED sensitivity term. The generalized differential approximation (sensitivity) is expanded in general terms as a linear combination of ratios of total differentials of the process changes due to technology innovations, i.e. product, energy, and efficiency. 
The total differential is:

$$
\Delta f_{\text {Tech }}=\frac{\partial E}{\partial \eta} \Delta \eta+\frac{\partial \eta}{\partial C} \Delta C+\frac{\partial C}{\partial \mathrm{P}} \Delta \mathrm{P}+\frac{\partial \mathrm{P}}{\partial E} \Delta E+\varepsilon
$$

Where, $\boldsymbol{E}, \boldsymbol{\eta}, \boldsymbol{C}, \boldsymbol{P}$ are the energy, efficiency, savings, and product, respectively and $\boldsymbol{\varepsilon}$ is the error associated with the approximation and is ignored in the EDA. These sensitivity parameters are based on a total derivative calculation and are approximations to the first partial derivatives of a multiple variable function.

ORNL directed the DOE's industrial wireless program for several years, overseeing the development and deployment of the standards-based technology in harsh environments for the heavy industries identified by the NAS study. Fig. 5 illustrates the history of that effort and its culmination in suitable standards supported by international standards bodies. Over the intervening years, DOE/ORNL has helped facilitate global industrial wireless standards, assisted with numerous demo installations, and documented successes at "permanent" installations. Included in the Appendices are excerpts from success stories gathered in support of this program over its multi-year lifespan.

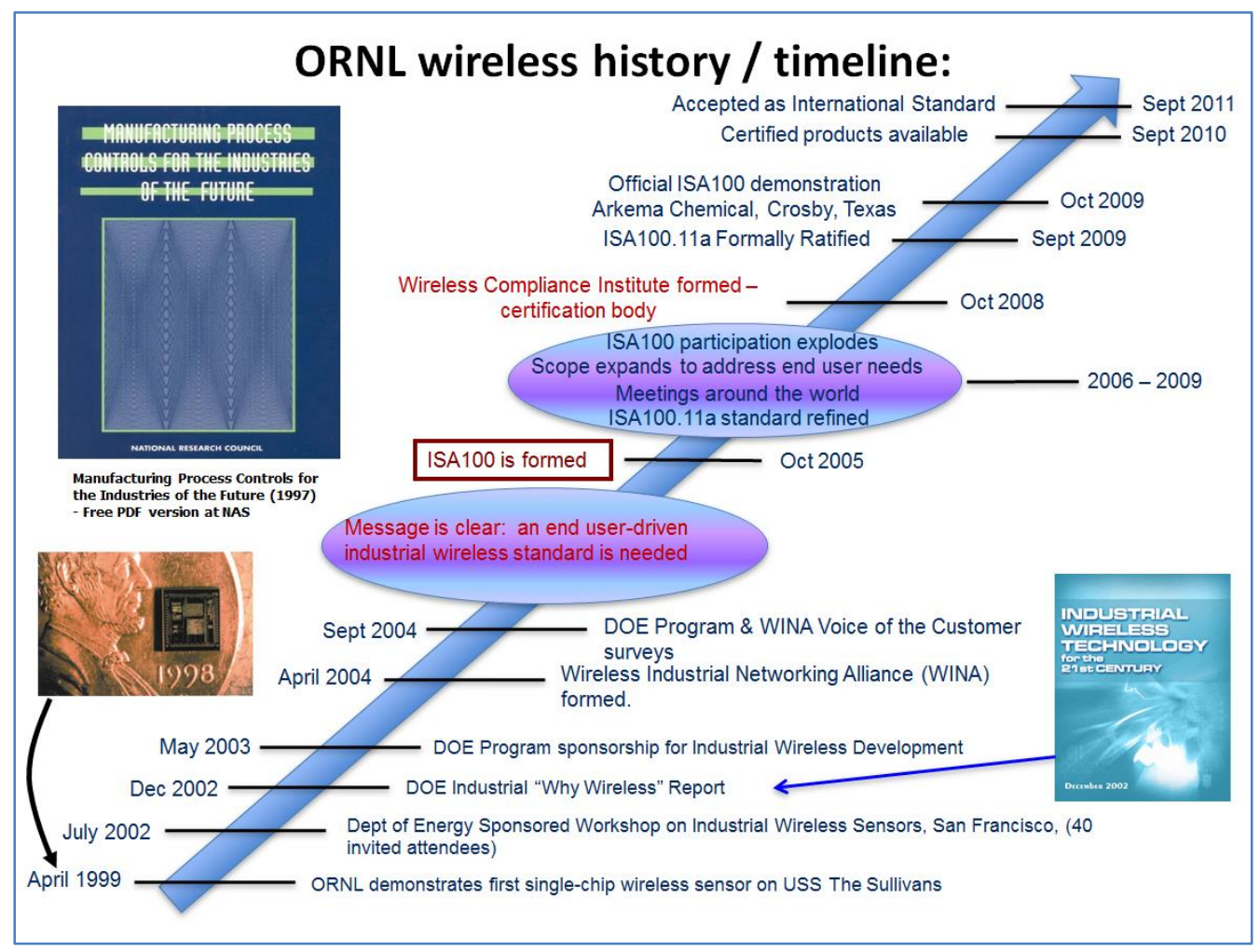

Fig. 5. ORNL/DOE industrial wireless program history.

Tying together the EDA process, a suitable industrial wireless infrastructure, and breakthrough energy analytics, this project showed that the potential anticipated by the NAS study could be realized with commercial off-the-shelf technology in a real-world steel manufacturing facility. Engineering the system from the ground up, based on established engineering practices applied to new emerging technologies, proved successful beyond the expectations of the end users and the vendors. 


\section{Wireless Technology Benefits}

DOE studies consistently show that opportunities exist to improve energy efficiency in steel manufacturing. Steel mills continue to be major energy consumers with ample opportunities for bringing to bear new energy efficiency technologies. This project has shown that with the improved charge carbon measurement resulting from the wireless monitoring system, process efficiency can be improved through the reduction of electrical and charge carbon consumption and reduced steel batch processing times since less electrical energy is required. It is estimated that the electrical energy consumption could be reduced by 5 to $10 \mathrm{KWH}$ per scrap ton ( 6 to $11 \mathrm{KWH}$ per cast ton) and the charge carbon consumption by as much as $500 \mathrm{lbs}$. per batch equaling a reduction in chemical energy by $20 \mathrm{KWH}$ per scrap ton $(22 \mathrm{KWH}$ per cast ton). Cost savings are projected to be in the $\$ 1$ per cast ton range $(\$ 750,000$ annually).

Historically, ORNL has worked for many years with DOE's Advanced Manufacturing Office (AMO) and its predecessors, Industrial Technologies Program (ITP) and the Office of Industrial Technology (OIT) to investigate opportunities to realize the potential energy savings identified in the academic studies published over the years. U.S. Steel had been a partner in the development of methodology known as "Enterprise Derivative Analysis" that was used on this project to target those steps in the steel manufacturing process where the greatest benefit could be gained with the least investment. This approach is published and available in the literature and on the DOE web site.

Another breakthrough occurred in 1997 when an NAS study (Fig. 6) showed that significant amounts of energy could be saved with the deployment of robust, secure wireless sensors for better energy awareness and faster response to upsets.

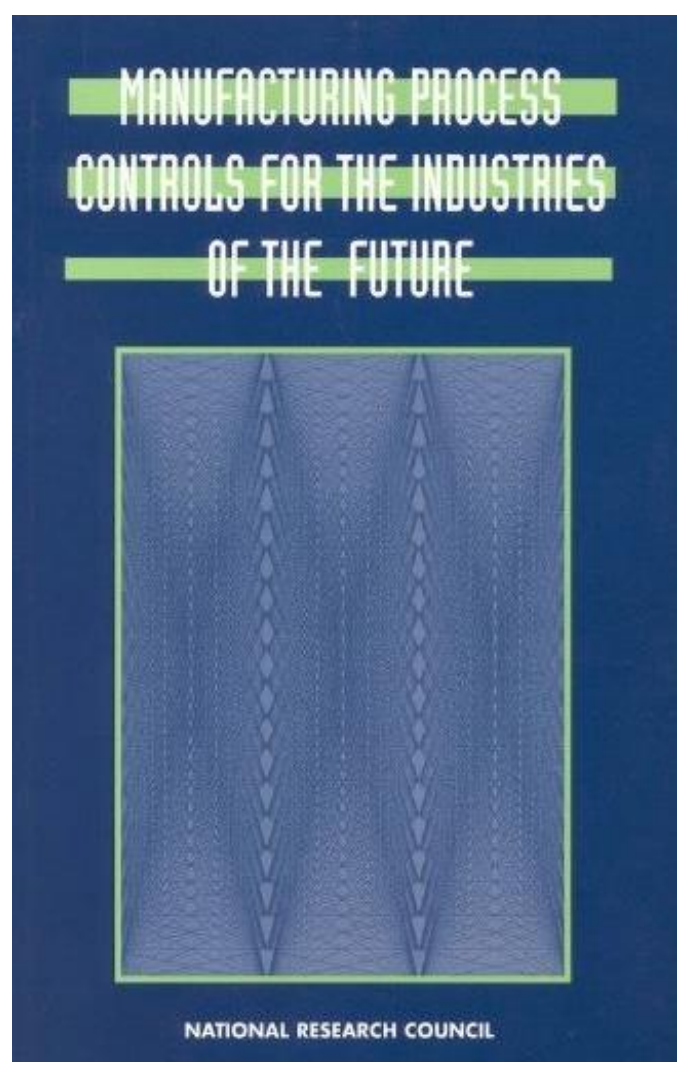

Fig. 6.1997 NAS study showcases wireless. 
The ORNL/DOE program included numerous workshops, showcasing success stories, implementation strategies and approaches being used around the industrial marketplace. Fig. 7 came from one of those workshops held at ORNL in 2007.

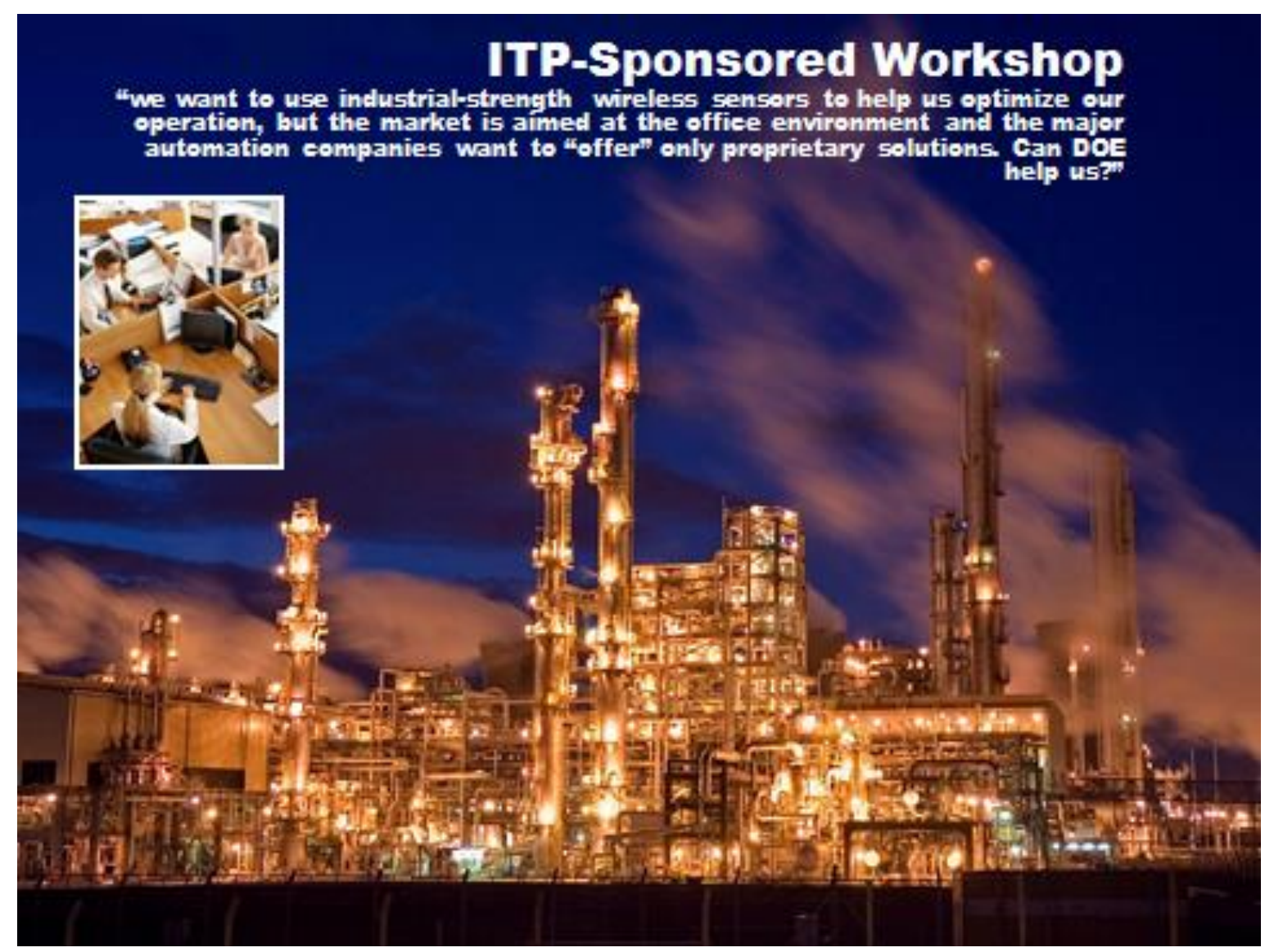

Fig. 7. ORNL/DOE industrial wireless program workshops pulled together key stakeholders.

The ORNL/DOE program quantified the requirements and performance characteristics necessary for successful deployment in harsh industrial environments. Fig. 5 and Fig. 8 show different views of the timeline for the activities culminating in the availability of globally accepted standards for industrial wireless technology. The Bibliography includes numerous articles written as part of the program to facilitate the acceptance of wireless technology under this program. The success stories showcased in the Appendices are part of this evolution. 


\section{The history of bus evolution}

- The Standard for Industrial

Wireless (ISA100) was developed by ISA to address all aspects of wireless technologies in a plant.

Industrial Wireles is the next major technology trangition in plaht gutomation.

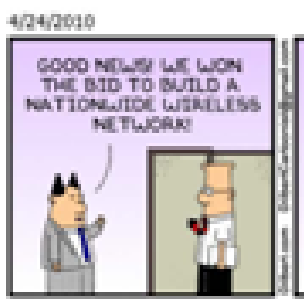

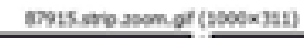

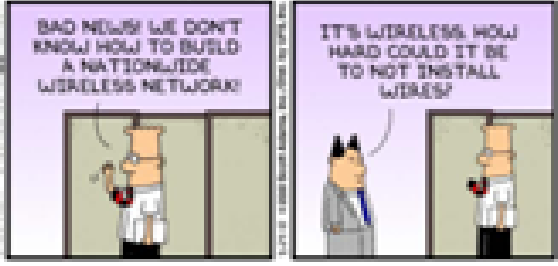

Dominant Measurement and Control Technology

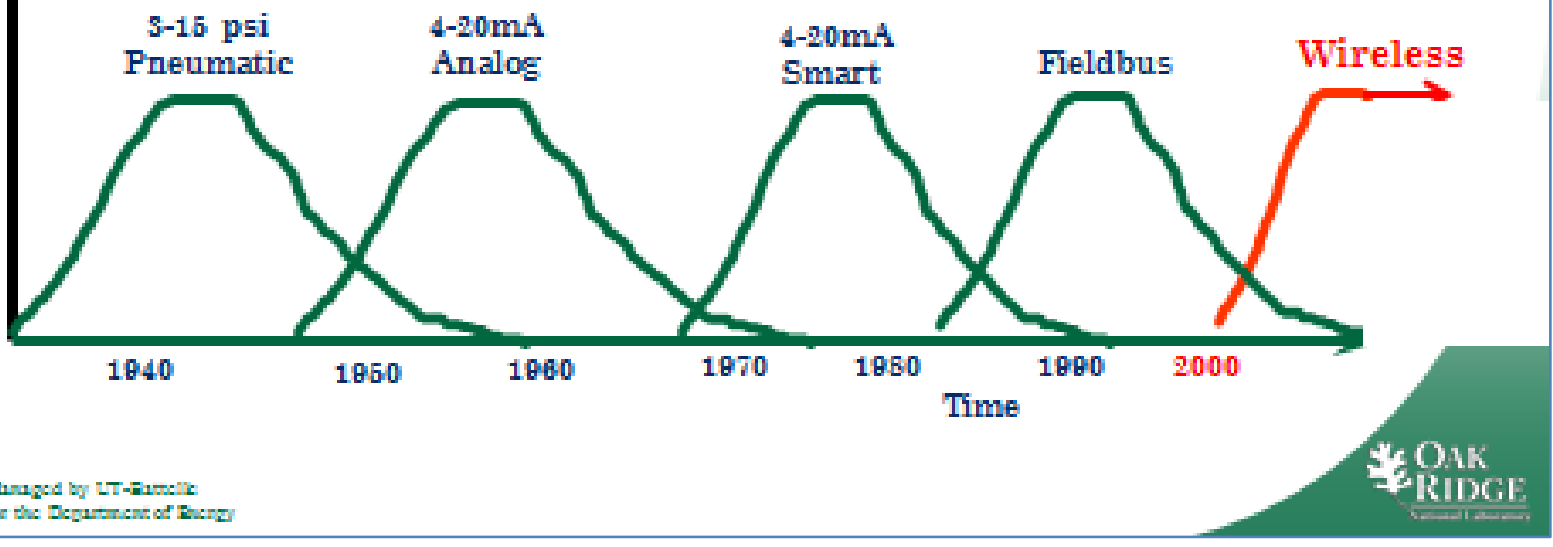

Fig. 8. Industrial wireless technology - from impossible to trivial. 


\section{Quantitative and Qualitative Benefits}

The goal for the deployment of wireless technology for this demonstration project was to illustrate that wireless had "come of age" and was "ready for prime time" deployment as a critical enabler for energy efficiency in harsh environments. The two sites selected for deployment allowed the demonstration of energy efficiency gains at an "integrated mill" at U.S. Steel and a "mini mill" at CMC. Fig. 9 illustrates the two processes and how they are related. The installations and operation of the wireless sensor networks went smoothly at both sites. The wireless sensor vendors selected (based on a rigorous requirements development and evaluation process) were different for the two sites but both were "industrial-grade" wireless solutions suitable for each of the harsh environments. Both installations (EAF and reheat furnace at CMC and BOP preheaters at USS) proved stable over the year-long burn-in process, and both systems have provided qualified data for the plant operators to use in making decisions regarding operating efficiency gains achievable at their respective site. This is an important attribute for any newly deployed system at either site. Without establishing the pedigree and confidence in the system, a commercial entity will be hesitant to change their business or operational conduct.

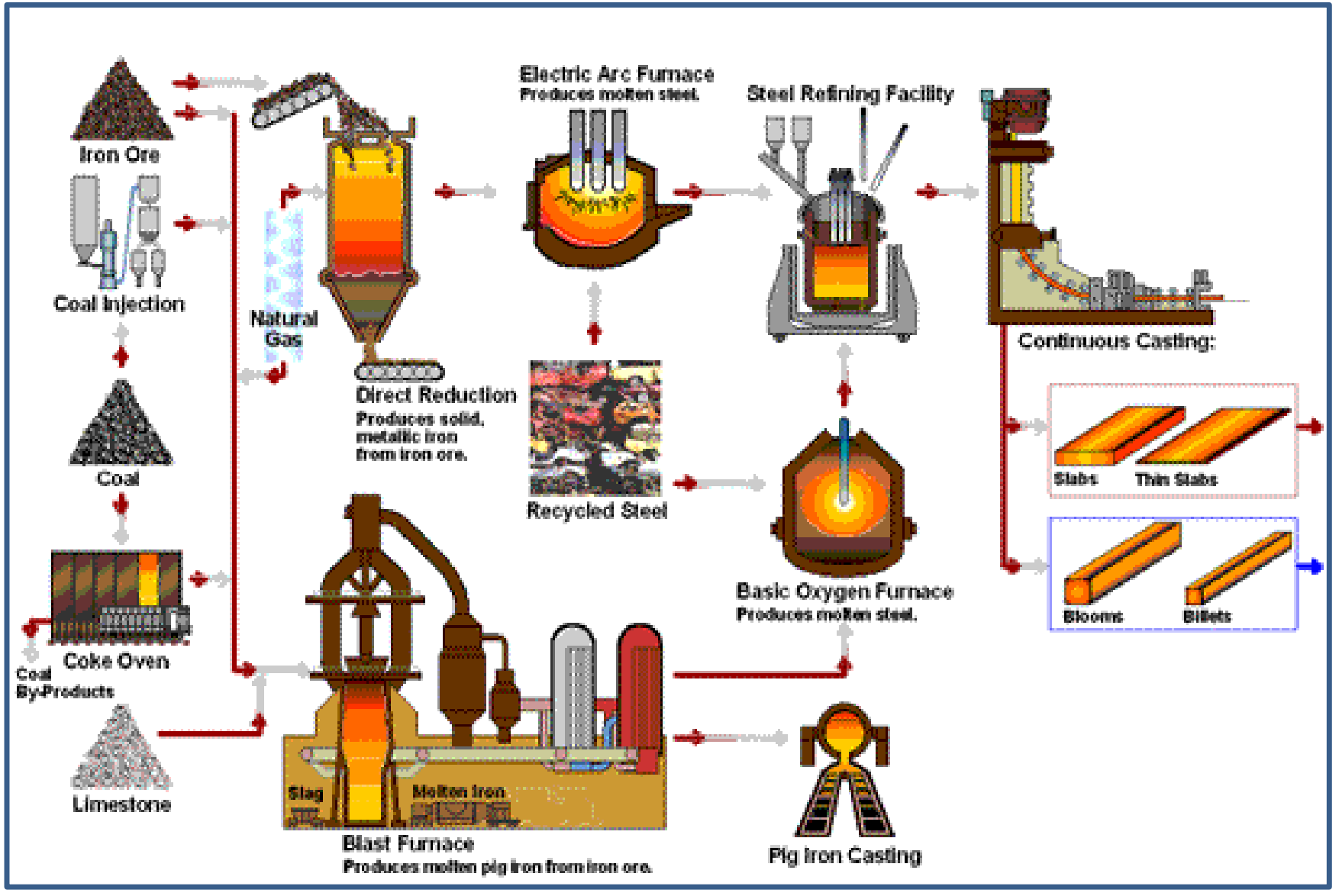

Fig. 9. Steelmaking flow lines showing electric-arc and blast furnace processes.

The steel making process offers a uniquely hostile environment for instrumentation, in general, and for wireless, in particular. 


\section{CMC Savings}

The CMC steelmaking process is energy intensive, both in the meltshop and the rolling mill. In the meltshop, the largest energy consumer is the EAF where scrap steel is melted and typically heated to $3,000^{\circ} \mathrm{F}$. Typical EAFs use $400 \mathrm{KWH}$ of electricity per ton of steel produced. Chemical energy is also added to the EAF in the form of natural gas, carbon, and oxygen. The total energy input to an EAF is typically $800 \mathrm{KWH}$ per ton of steel after converting the chemical energy to equivalent $\mathrm{KWH}$. Using a material and energy balance, the liquid steel from the EAF contains 40 to $45 \%$ of the total energy input. The other 55 to $60 \%$ of the energy is lost to slag, waste gases, and cooling water. These energy losses represent a tremendous opportunity for improvement if these losses can be measured, correlated to specific process conditions, and reduced through changes in equipment and operating practices. What the team set out to accomplish at CMC through the deployment of a wireless energy monitoring system included:

1. Establishing a methodology and approach to

a. Optimize ROI (initial expenses + re-occurring costs) based on total enterprise gains (\$+ energy)

b. Provide post-deployment measures of effectiveness (MOEs) and measures of performance (MOPs) that are measureable and quantifiable;

2. Employing wireless sensors in the operational environment without impacting or disturbing the process to prove these systems are industry ready;

3. Establishing confidence in the network

a. Demonstrated system reliability and availability

b. Resiliency of the system to be persistent; and

4. Developing and employing a new EAF control law.

The meltshop also has three natural gas-fired preheaters that are used to keep the ladles that hold the liquid steel hot prior to filling them with steel. In the rolling mill the largest energy consumer is the reheat furnace where billets (long rectangular-shaped bars) are heated from ambient temperature to $2,200^{\circ} \mathrm{F}$. Typical reheat furnaces are fired with natural gas and typically use $1.1 \mathrm{MMBtu}$ per ton of steel product, which is an equivalent of $322 \mathrm{KWH}$ per ton. Forty to $55 \%$ of this energy is transferred to the billet while the other 55 to $60 \%$ of the energy is lost to the waste gases, heating up the refractory, and cooling water. Like the EAF, these energy losses represent a significant opportunity for efficiency improvement once they are measured and understood in more detail. The site subsystem selection process to determine where the wireless monitoring system would be deployed was based on using the EDA strategy detailed above, resulting in three important operational parameters that would influence the selection. The analysis identified the following:

- The EAF has the highest average electrical energy content per unit product (KWH/Cast Ton). Compared to the ladle metallurgy station (LMS), the EAF offers the greatest opportunity for energy reduction/unit efficiency gain $(\mathrm{EAF}=393.95$ vs. $\mathrm{LMS}=11.94)$.

- EAF represents the best ROI from a consumable cost perspective given it has the highest average cost per unit product (\$/Cast Ton) equal to 38 times the consumable cost for the LMS.

- Additionally, a comparison of the ratio of consumable cost per KWH of electrical energy usage between the EAF \& LMS, the EAF is $24 \%$ higher), gives the advantage to the EAF.

From the analysis it was determined that the best opportunity for energy and operational cost recovery is at the EAF. 


\section{Meltshop Instrumentation}

Based on the initial EDA analysis (Section Enterprise Derivative Analysis Selection Process), the new wireless temperature sensors were positioned on several of the water-cooling circuits on and around the EAF. These measurements on the trace water circuits would be used to quantify the temperature rise in the cooling water as it is circulated around the process. The specific water temperatures were measured in the following cooling water circuits:

- EAF Roof

- EAF Sidewalls

- EAF Roof Elbow (where the waste gases exit the furnace)

- D1, D2, D3, D4, D5, D6, D7, D7-D8, and D9-D10 duct (9 total)

- Dropout box and old dropout box

- Ladle furnace roof

The water temperature measurements are then used to calculate the energy transferred to the water using the heat capacity of water, flow rate of water, and the supply (inlet) temperature of the water. Once the energy transfer rate is known, the rates can be tracked over time and totaled. Fig. 10 shows the general placements for the cooling water circuits. Fig. 11 shows the derived heat loss rates from a single EAF heat cycle calculated using the signals from the wireless energy monitoring system.

\section{Measure and Quantify benefits to CMC - EAF and Ductwork Cooling}

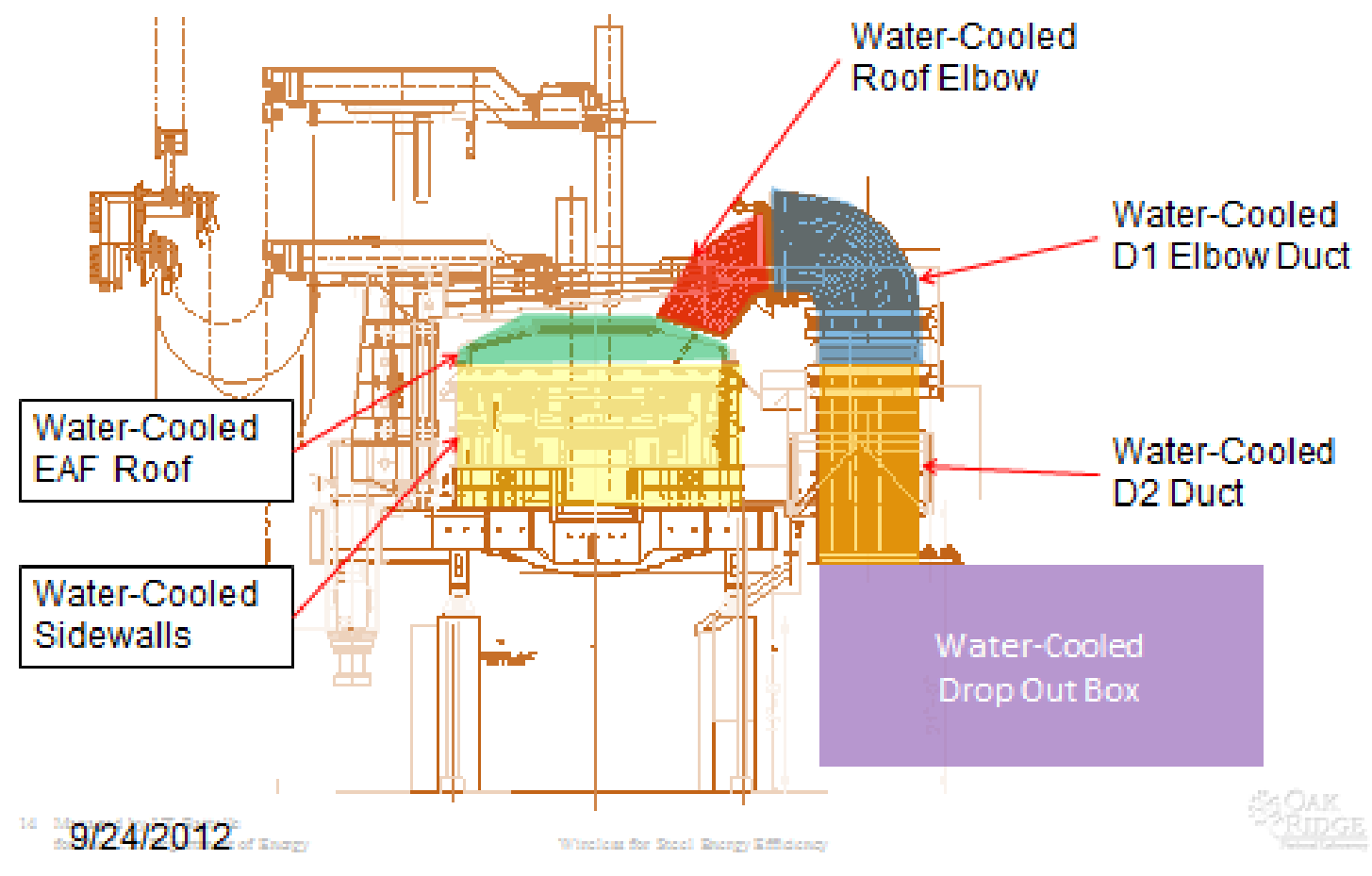

Fig. 10. Topological view of placement of the heat trace sensors representing the bulk of sensors deployed in CMC wireless energy monitoring system. 


\section{South Carolina Wireless Instruments Energy Loss Rate to Duct Cooling Water}

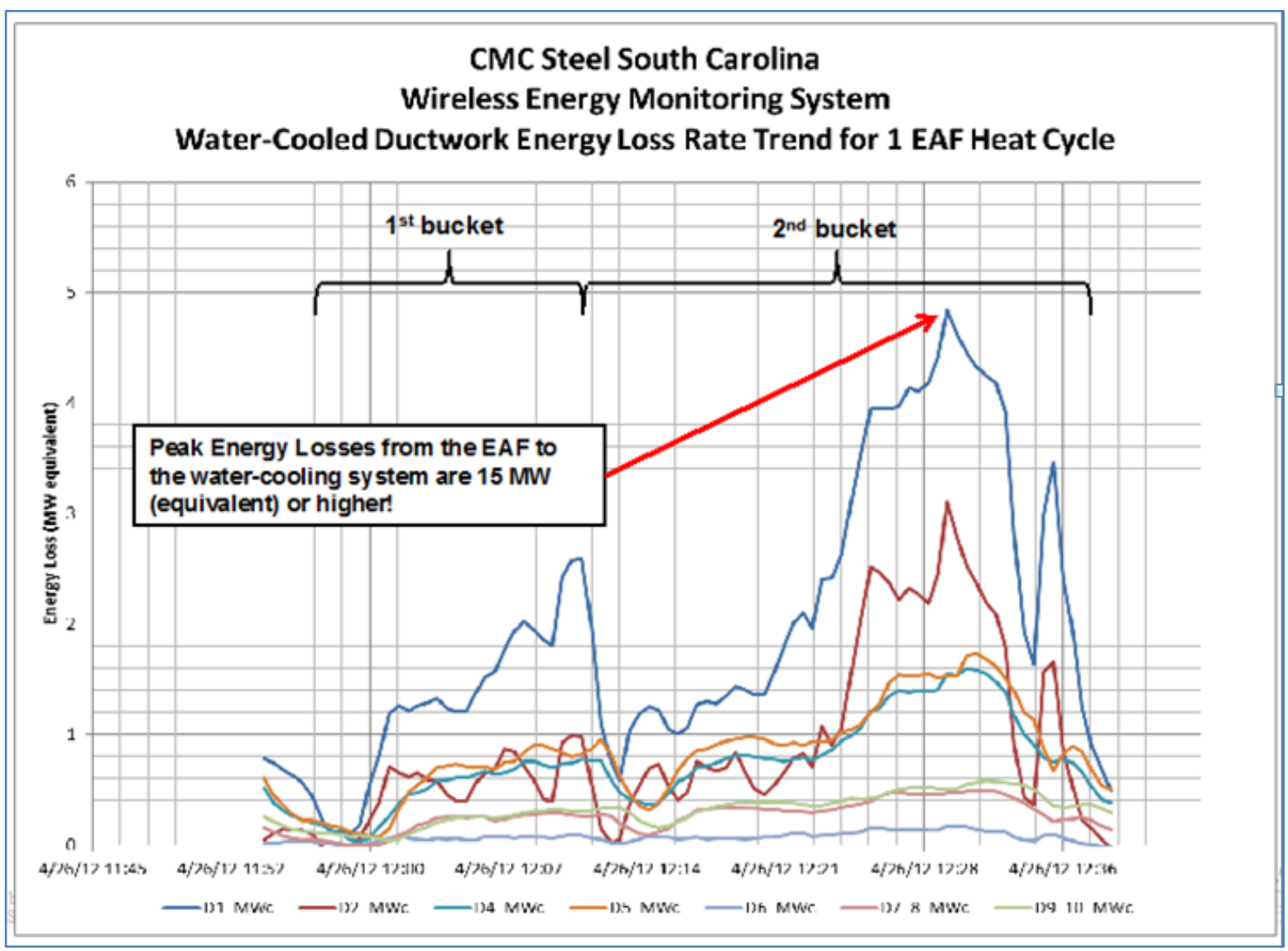

Fig. 11. Heat loss trend projections obtained from the CMC wireless energy monitoring system.

Since the energy contained by the waste gas from the EAF is significant, additional wireless instruments were installed on the canopy hood located over the top of the EAF and also in the direct evacuation duct. These measurements can be used to determine the mass flow rate of the waste gases through each duct. The instrument installed in the EAF duct failed due to high temperatures, but enough information was obtained to make a reasonable approximation for the flow rate through this duct.

Wireless temperature monitors were also installed in two of the ladle preheaters in order to begin monitoring their operation. Altogether, 18 wireless instruments were installed in the meltshop.

\section{$\underline{\text { Rolling Mill Instrumentation }}$}

A wireless flow and temperature sensor was installed in the exhaust stack of the reheat furnace in order to begin quantifying the energy losses and totalizing the energy losses for each day. This was the only instrumentation installed in the rolling mill. 


\section{Wireless Energy Monitoring System Hardware and Performance}

The wireless energy monitoring system went "live" in September 2011 and has been operating reliably since that time. Fig. 12 provides a notional architectural overview of the system while Fig. 13 provides a more detailed description of sensors, gateways, and connectivity.

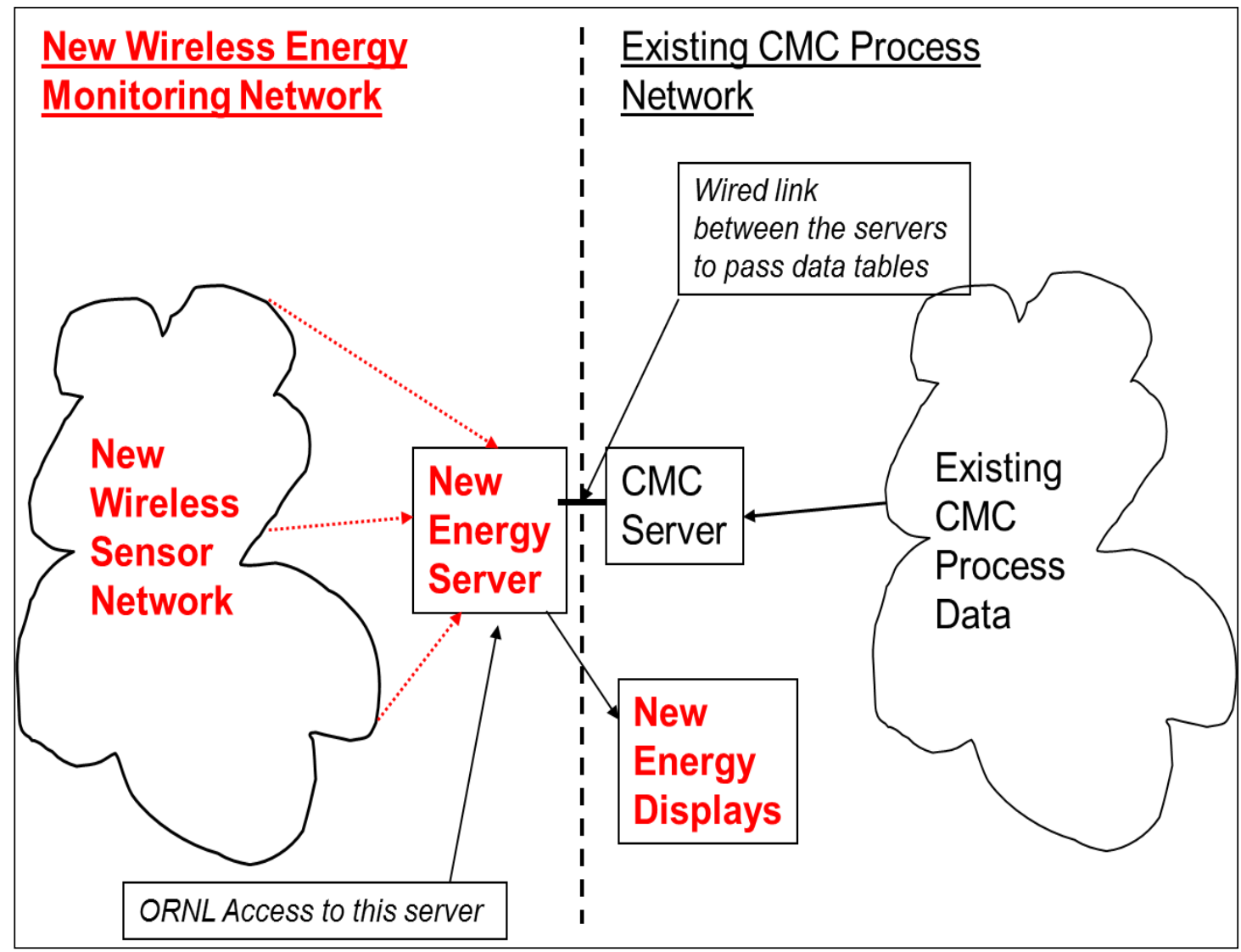

Fig. 12. A notional view of the wireless energy monitoring system deployed at CMC Steel South Carolina. The important feature is the isolation through the firewall of the new wireless sensor network and CMC's existing process network. 


\section{Energy Monitoring System Infrastructure}

CMC Steel Site IT Building Structure

\section{Melt Shop - Northside}

Emerson 848T \& 648

(5) temperature signals
Wonderware InTouch 10.1

- (10) Terminal Services

-SQL Data Access

Dell Poweredge server

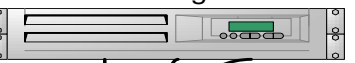

(3) NICs - Monitoring OPC I/d TSE Clients, Server Data Accest

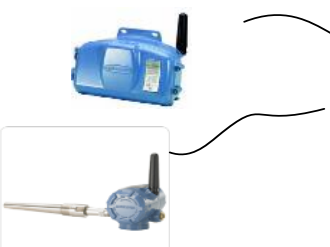

Wireless

Transmitter

Devices

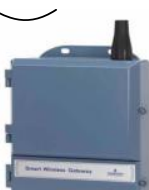

Emerson

Smart

Wireless

Gateway
Power \& fiber optic from
$2^{\text {nd }}$ floor control room area
Transceiver

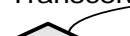

floor control room Connectors
Conner Optic

L1/L2 Bridge for monitoring network

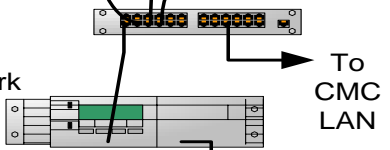

Hub w fiber optic \&

RJ45 connections

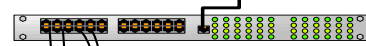

elt Shop - Southside

(3) Emerson 848T \& (3) THUM units

(14) signals total
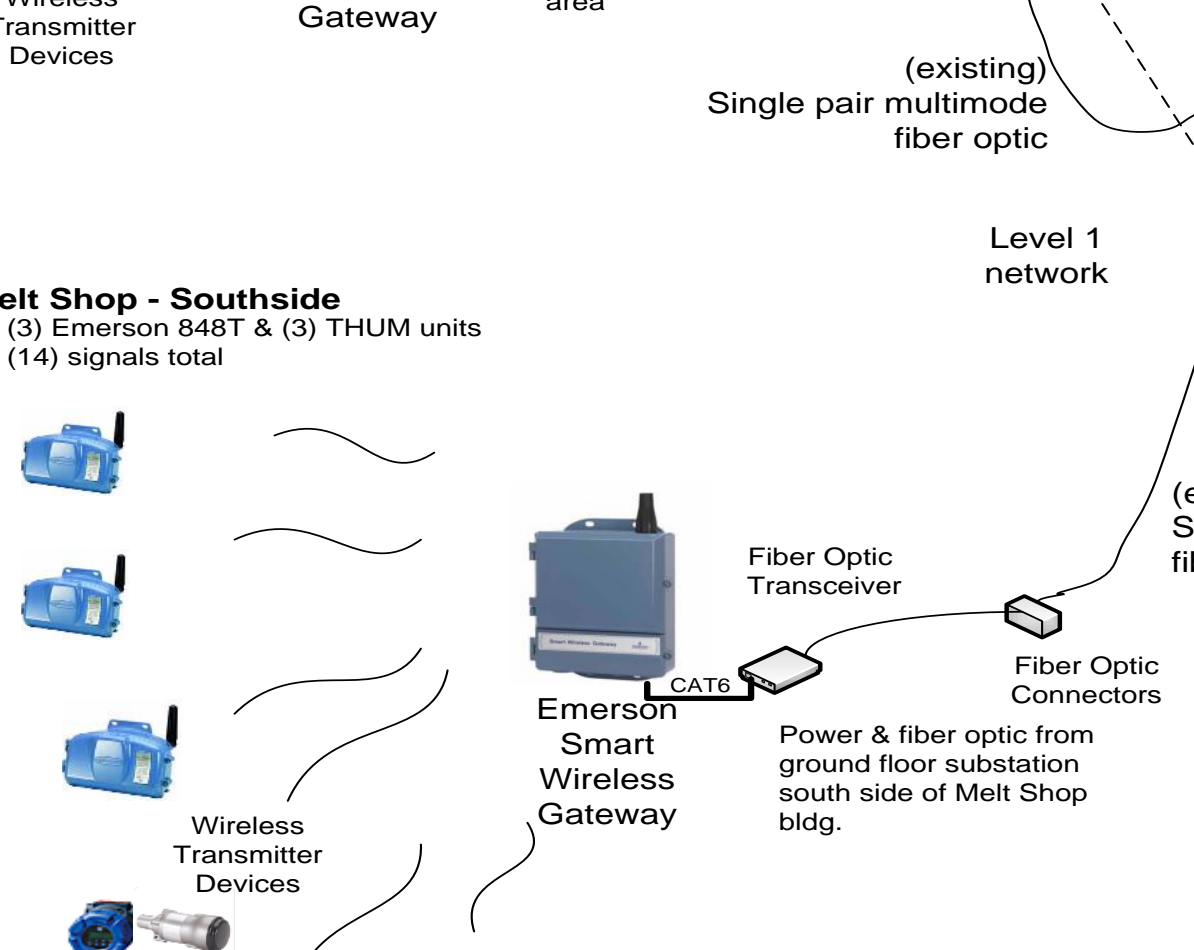

Level 1 network

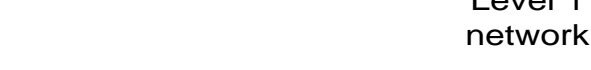


The instrumentation and energy monitoring system provides the following positive operational aspects:

- It is simple to maintain and add additional wireless devices

- Battery life is nearly 3 years with the update rate of 16 seconds

- Wireless coverage of the rolling mill and meltshop is excellent, using only 2 gateways to collect data from all sensors

- The system is self-organizing so even if a device cannot communicate with a gateway it will communicate with neighbors to send the data back to the gateway

- All of the data are stored in a Structured Query Language (SQL) database that can be queried using Excel

- The data are available "real-time" through our plant control system WonderWare ${ }^{\circledR}$

- New sensors can be added without process disruptions or excessive operational costs

From the operations of the wireless sensor network, CMC has drawn the following conclusion: significant process improvement and reduction in electrical and chemical energy can be gained by coupling the wireless sensor system measurements with a proposed (new) charge carbon weighing system. The following is the reasoning that supports this assertion.

The EAF operation in South Carolina is capable of adding carbon to each batch of steel in two ways: with the scrap charge and injected through the burner injectors in the walls of the furnace. The carbon added with the scrap charge has a reputation throughout the steel industry as having poor recovery, but quantifying the impact has not been very well documented. Fig. 14 provides an operational view of the instantaneous energy losses through the EAF off-gas water-cooled ductwork for three back-to-back batches (heats) of steel. The key operating parameters for the first two batches are nearly identical except for the amount of carbon added with the scrap charge. The first heat (Heat \#2020265) uses 1,400 lbs. of charge carbon while the second heat (Heat \#2020266) uses only $300 \mathrm{lb}$. The third heat (Heat \#2020266) uses 1,300 lbs. of charge carbon but also added about 5\% extra scrap. As seen, the D1 duct losses are higher in magnitude when more charge carbon is added with the scrap. In both the first and last batches, the D1 energy loss rate peaks at approximately 4.5 MW-equivalent. The second batch, which used only $300 \mathrm{lbs}$. of charge carbon shows D1 energy loss rate peaking at 3.8 MW-equivalent. In a similar fashion, lower energy loss rates are experienced in the other water-cooled ducts (D2 through D10).

The energy losses through the water-cooled duct are due to higher temperatures in the off-gas and also heat generated during the combustion of carbon monoxide $(\mathrm{CO})$ in red and hydrogen $\left(\mathrm{H}_{2}\right)$ in orange contained in the off-gas. Fig. 15 shows a trend of the composition of the off-gas exiting the EAF roof elbow. The figure shows that the higher losses to the water-cooled ductwork are consistent with the higher levels of $\mathrm{CO}$ and $\mathrm{H}_{2}$ in the off-gas. 


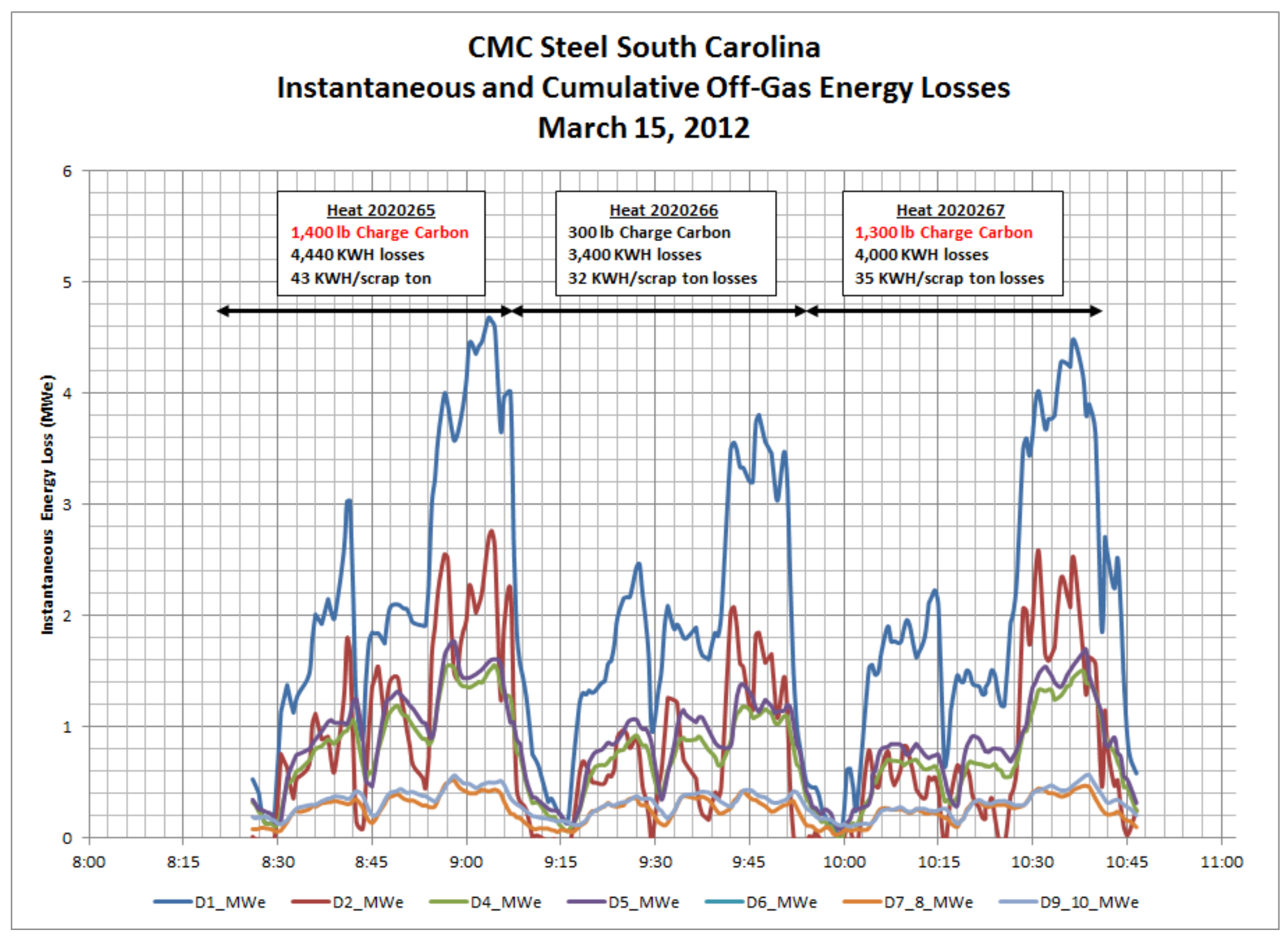

Fig. 14. Instantaneous energy losses through the EAF off-gas water-cooled ductwork for three back-to-back batches (heats) of steel. 


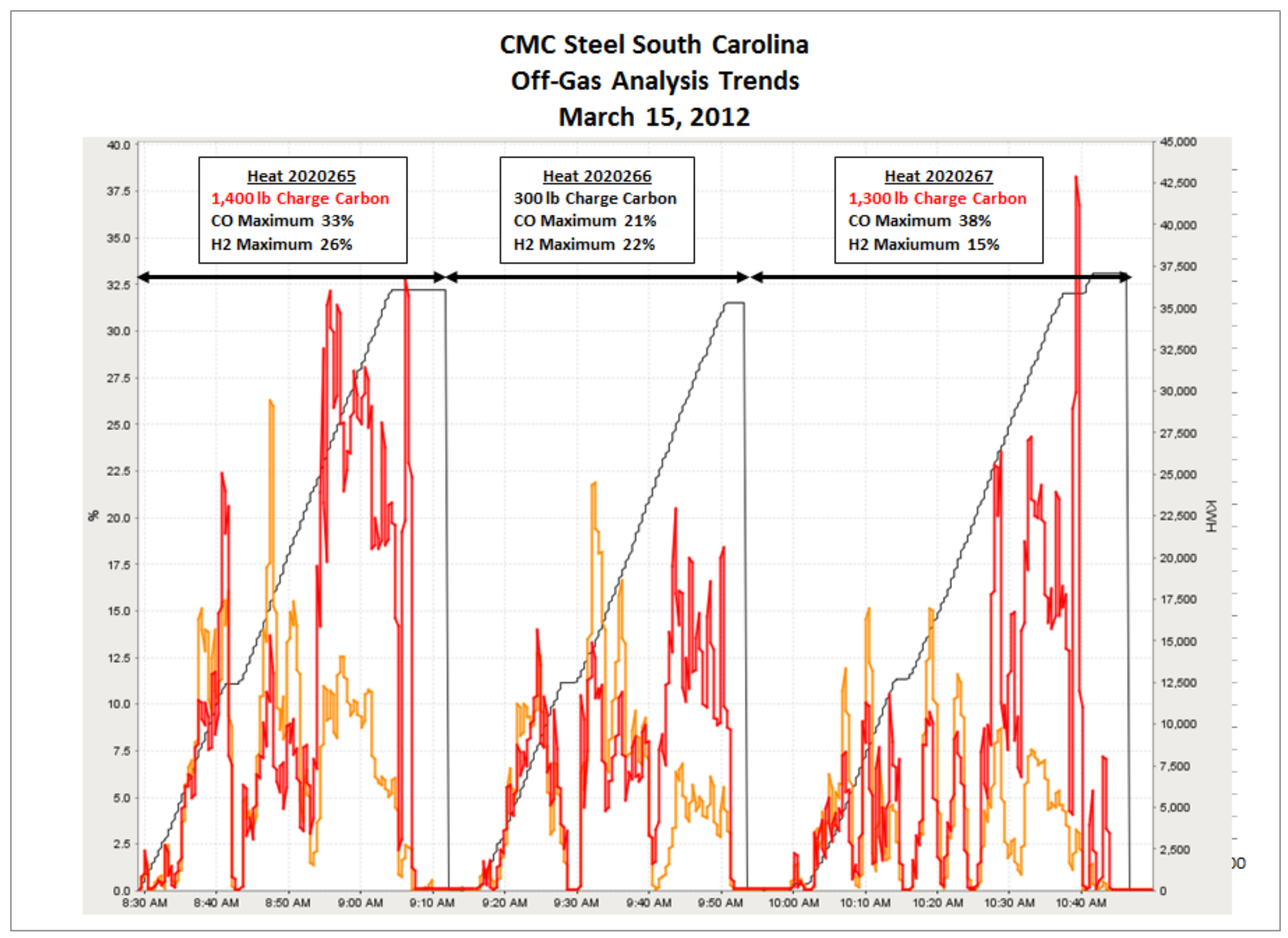

Fig. 15. D1 duct losses are higher in magnitude when more charge carbon is added with the scrap. 
Despite charge carbon's poor reputation, many EAF operators apply the philosophy of "more is better" to carbon and other chemical energy sources. As a result, their thinking is something like "if $500 \mathrm{lbs}$. of charge carbon is good, then 1,500 lbs. must be better." A convoluting factor in South Carolina is that the weighing system for charge carbon is imprecise. The charge carbon weight is determined by difference using the scrap charge scales, which are measuring weights from 0 to 80 tons of scrap, scrap bucket, and carbon. Measuring a differential of 500 to $1,000 \mathrm{lbs}$. using a scale that is already loaded with 75 tons provides less than acceptable precision.

CMC has used the wireless energy monitoring system to quantify the impact of the amount of charge carbon on the EAF electrical energy consumption and energy losses to the waste gases. Fig. 16 shows the average electrical energy consumption (KWH per scrap ton) and totalized off-gas energy losses (equivalent KWH per scrap ton) for increasing amounts of charge carbon for the 3 months of operation between March and May 2012. The graph shows that as the amount of charge carbon increases, the amount of energy lost to the off-gas also increases. If charge carbon was absorbed into the steelmaking process efficiently, the energy losses to the off-gas would stay the same, instead the energy losses increase.

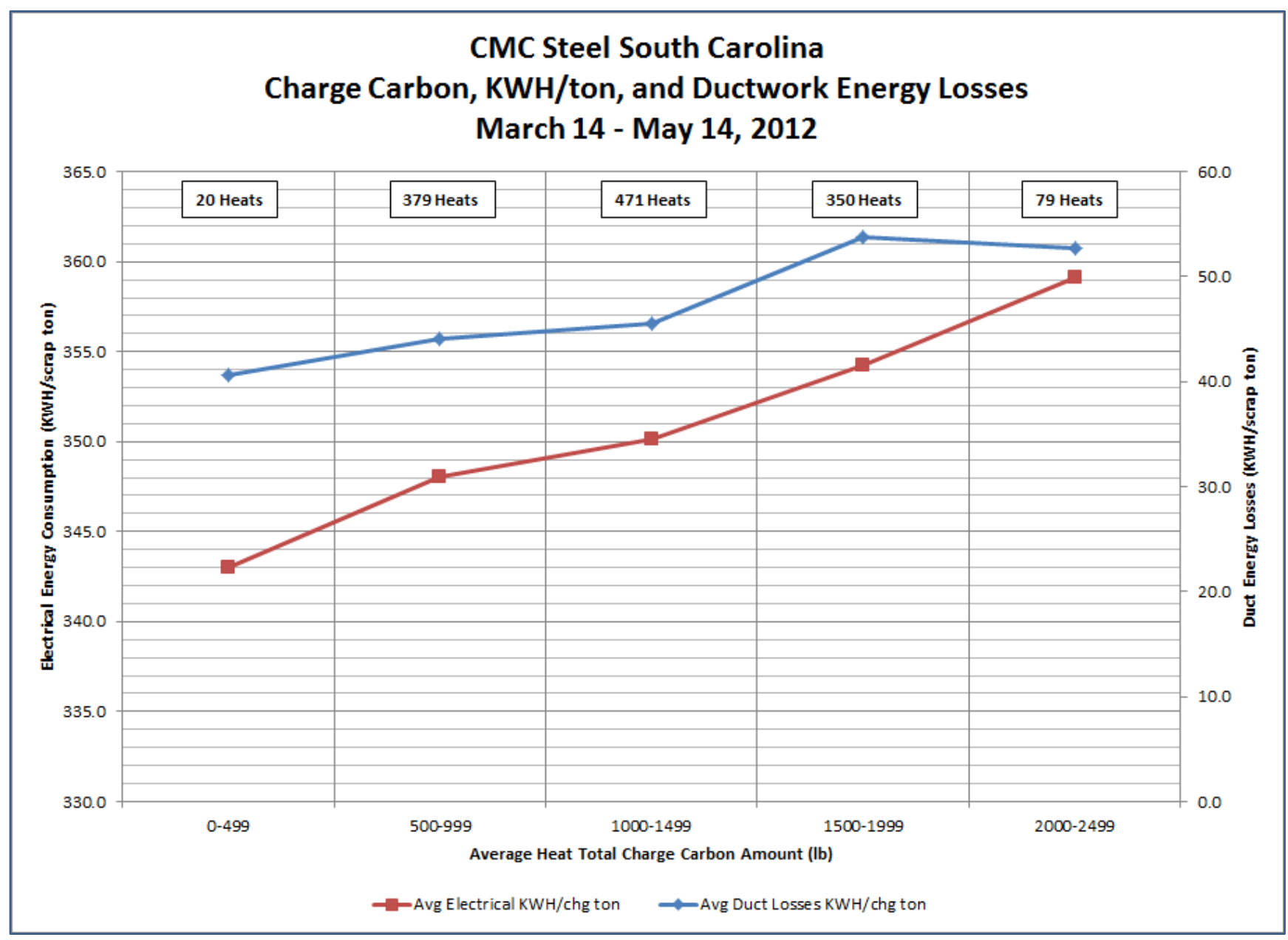

Fig. 16. Average electrical energy consumption (KWH per scrap ton) and totalized off-gas energy losses (equivalent KWH per scrap ton) for increasing amounts of charge carbon for the 3 months of operation between March and May 2012. 
The analysis of the EAF operating data and the supporting data from the wireless energy monitoring system has lead CMC to recognize that using larger amounts of charge carbon leads to higher electrical energy consumption and higher energy losses to the off-gas system. The imprecision in the measurement of charge carbon weight leads to inconsistent charge carbon additions and therefore inconsistent EAF

electrical consumption. As a result, $\mathrm{CMC}$ is preparing a design, budget, and capital request for a new system for weighing the charge carbon.

The improved charge carbon measurement will improve process efficiency by reducing electrical and charge carbon consumption and reducing steel batch processing time (since less electrical energy is required). Electrical energy consumption could be reduced by 5 to $10 \mathrm{KWH}$ per scrap ton (6 to $11 \mathrm{KWH}$ per cast ton). If charge carbon consumption can be reduced by $500 \mathrm{lb}$ per batch, then this equates to a reduction in chemical energy by $20 \mathrm{KWH}$ per scrap ton ( $22 \mathrm{KWH}$ per cast ton). The cost savings associated with these changes is expected to be in the $\$ 1$ per cast ton range and CMC Steel South Carolina typically produces 750,000 tons per year.

Other wireless system figures of merits include

- System availability $\left(\mathrm{A}_{\mathrm{o}}\right)$ is $>98 \%$ based on anecdotal reports from plant and field personnel. The life-cycle costs of the system are within acceptability, given that the only outages were attributed to operational issues and not the system.

- EDA provided a well-defined methodology and approach to selecting points of entry for energy and cost recovery in the plant.

- The wireless monitoring system was simple to maintain.

- New sensors can be added without process disruptions or excessive operational costs.

- Battery life was not an issue.

- Wireless coverage of the melt shop is excellent.

- The data were available "real-time" through CMC's plant control system.

\section{Benefits Assessment}

ORNL participated in a detailed analysis in order to provide more rigorous decision-making information. The analysis provided CMC with the information and the wireless sensor network verified the efficiency gains predicted, closing the loop on the entire process.

The wireless energy monitoring system has provided significant benefits to $\mathrm{CMC}$ in both the operations and maintenance departments. These benefits include

- Verifying that the plant equipment in the EAF and reheat furnace (plant layout shown in Fig. 17) is performing as expected.

○ Cooling water is maintaining acceptable temperatures to prevent equipment failure

$\circ \quad$ Ladle preheaters are maintaining their set point temperatures

- The EAF and EAF canopy hoods are being evacuated at acceptable levels

- New process information.

$\circ$ CMC has never had real-time instantaneous or totalized energy loss information available

- Instantaneous and totalized energy losses to the cooling water and evacuation system are higher when more carbon is added to the EAF

- Totalized energy losses are larger when the process cycle time increases

- Just as there is variation from batch to batch in energy consumption, there is also variation in energy losses from batch to batch 


\section{CMC Steel South Carolina Plant Overview Looking to South}

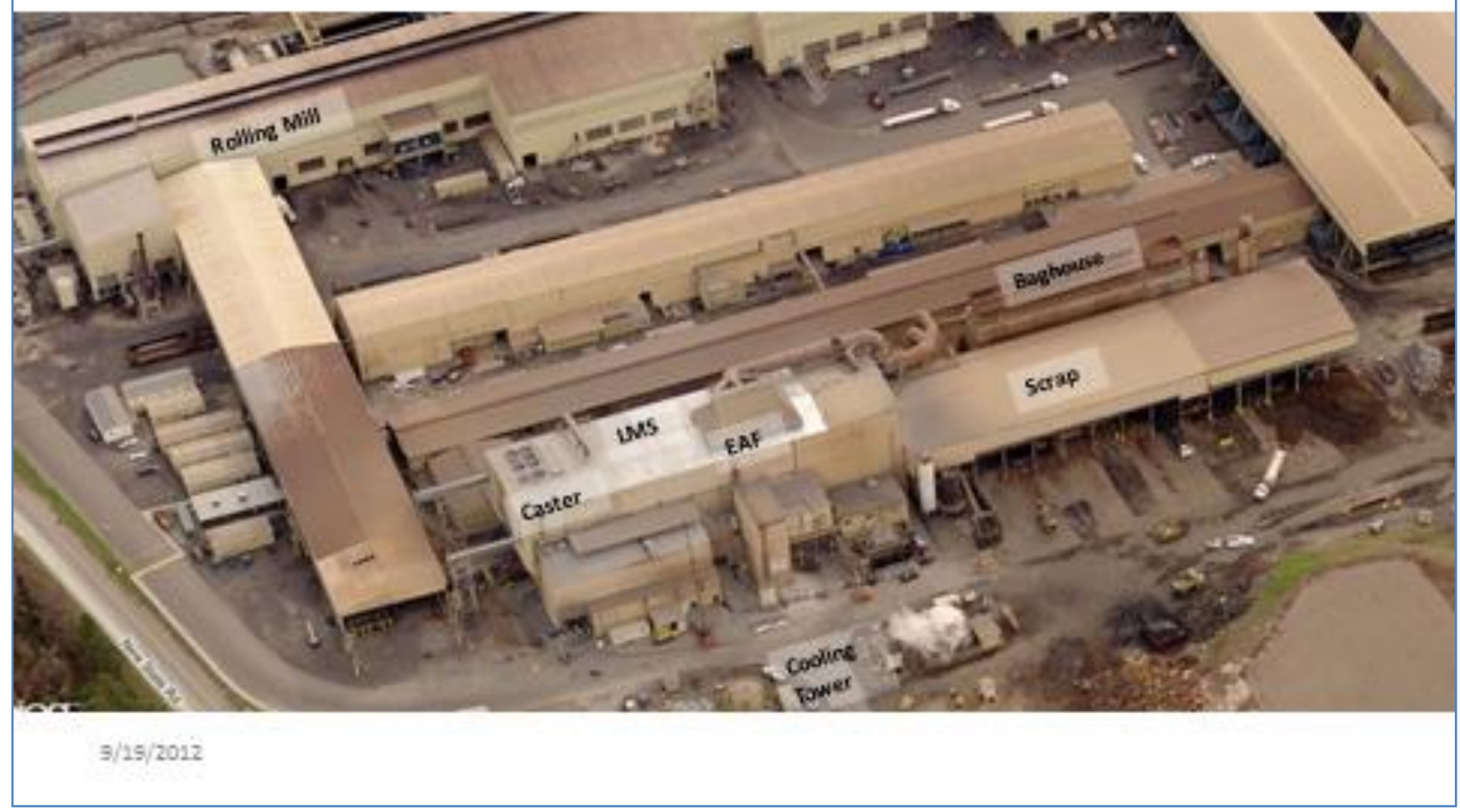

Fig. 17. Aerial view shows the layout of the CMC EAF mill in Cayce, South Carolina.

To verify that the deployed wireless energy system (1) is an accurate representation of the system's dynamical state, (2) is a direct measure of the system's response to control inputs, and (3) is correlated to changes in energy usage [product per unit quantity per unit energy use], parameters must be derived that act as indicators of system performance. These derived parameters must verify

1. The data pedigree.

○ Data are stationary (not time varying) across all environments and operational regimes

- Data are strongly correlated with system's operations

- Secondary effects on data from the environment are taken into account

2. Energy Savings (Energy Audit Indices).

- Energy seasonal (cyclic) impacts must be considered and included in energy calculations

- Direct energy savings can be correlated with any control response (either direct or indirect - closed loop or open loop)

- Any affects from current energy savings campaigns must be understood and taken into account when final energy calculations are done

$\circ$ Direct measures of energy savings are measurable and quantifiable 


\section{U.S. Steel}

Specifically, the U.S. Steel project provided [new] wireless sensors and actuators that were chosen and strategically located (distributed) based on their value proposition and projected energy savings to U.S. Steel. The specific category and type of sensors and actuators were selected based on conducting an EDA that derived overall impact and value to the 'energy savings' hypothesis. From this, an appropriate system definition and design were developed leading to theoretically optimal placement of all devices within the plant and the genesis of communication networks for providing process information for appropriate actions to be taken. This protocol and analytic approach provided the basis and venue for adopting new operational strategies to validate the efficacy of the wireless sensor system. The system used commercial-off-the-shelf equipment that had benefitted from the previous DOE wireless research and development investments. Deployment emphasized standards and protocols and effective measures of system reliability, availability, security, and quality of service indicators such as throughput and latency. The wireless sensor system and network facilitated man-in-the-loop control for air, steam, electrical, and other energy intensive systems in multiple sites at the E.T. Plant.

The E.T. Plant is known as the plant that "made Pittsburgh the steel city." At the time of its construction, it was hailed as the "most perfect establishment of its kind in the world" according to an article in the Pittsburgh Daily Gazette on September 6, 1875. Today two blast furnaces remain on the site (Furnaces 1 and 3). They feed molten iron to the Basic Oxygen Process (BOP) based furnaces, which supply molten steel to the continuous caster. The caster converts molten steel directly to slabs. In 2005, the mill produced 2.8 million tons of steel, equal to $28 \%$ of U.S. Steel's domestic production. In April 1995, the mill was designated a historic landmark by ASM International, a society that honors works of structural engineering.

The E.T. Plant is a part of U.S. Steel's Mon Valley Works, comprising four sites near Pittsburgh, Pennsylvania. The Clairton Plant--where coal is converted to coke--is the first step in the process that feeds the integrated mill at the E.T. Plant. At the E.T. Plant, iron ore is converted to steel and cast into slabs. These steel slabs are finished into hot-rolled, cold-rolled and coated sheet as well as other products at the Irvin Plant. For customers in certain industries, the Fairless Plant finishes cold-rolled products into galvanized sheet. An integrated steel plant or mill is one where 'input' to the plant is all raw materials, consumables and supplies, and the 'output' is finished steel products, such as hot rolled sheets, plates, cold rolled steels, galvanized steels, coated steels, bars, rounds, structural sections, rails etc. At one point, many of the Mon Valley Works steel plants were 'integrated' - meaning they processed raw materials into steel products. The Clairton Plant is and always has been a Coke Oven plant, manufacturing coke and many other coke oven by-products. The Clarion Plant has customers outside of the U'S steel organization, supplying coke to non-US Steel entities. Technically, therefore, none of the plants currently comprising the Mon Valley Works qualifies as an "integrated mill" since the processes are scattered geographically between Pittsburgh and Philadelphia. The E. T. Works, however, is as close to an integrated mill as was available for the project testing. The U. S. Steel Plant, Gary Steel Works in Gary, IN is an example of an "integrated mill" that still exists. The E. T. Plant today is known as a "primary iron and steel processing plant that makes semi-finished steel products (steel slabs) from raw materials.

In addition to its historic significance and the scale of the process, the E.T. Plant was chosen for its opportunity to test the wireless technology and prove its value. The management and staff at E.T. were supportive of the project and greatly facilitated the success. They embraced the new technology and made great strides to integrate the data streams into day-to-day operations, including allowing the added system to use existing IT infrastructure and placement of the system server directly into the main computer room of the plant. 
An additional benefit of the wireless sensor system is its support of U.S. Steel's emphasis on 'Safe Steel' by providing additional situational awareness that can be used to positively affect plant safety. The project's mandate to "do no harm" must be honored, but the possibility of safety enhancements resulting from the additional sensing capability was considered as well.

It was critical to the success of the project that the wireless energy monitoring system deployed in the E.T. Plant did not interfere with U.S. Steel's mission of making "Safe Steel." Therefore, a substantial effort was put into defining a sensor suite that did not currently exist/function at the E.T. Plant and would provide the most information to influence operational decisions to affect energy savings.

E.T. Plant personnel provided a comprehensive and prioritized list that was included in the solicitation. In addition to priority, they provided an indication of whether installation would require local or plantwide shut down. This constraint greatly influenced which sensors would be installed.

The E.T. Plant IT infrastructure is defined by two levels. One is considered to exist at the equipment direct control and monitoring network while the other is considered the "business network."

\section{Level 1 - Equipment Direct Control \& Monitoring}

Level 1 consists of primarily programmable logic controllers (PLCs) and supervisory control and data acquisition (SCADA) equipment and is largely isolated inside each unique E.T. operating process, where each is responsible for selection and management of the appropriate system for its operational needs. Most of the Level 1 system does not interface to the Level 2 system with a few firewalled exceptions. Level 1 systems are supported by an equipment vendor, and no plant or corporate restrictions are enforced on the operating system or hardware selection. The most integrated Level 1 system is a virtual local area network (VLAN) on the U.S. Steel network. A unique location in the plant where Level 1 and Level 2 systems mix is at the pulpits for the continuous caster operation.

\section{Level 2 - Business Network}

Level 2 consists of the backbone LAN infrastructure and spans the entire plant facility and is integral with the corporate network. Level 2 falls fully under the policy control of the IT department and has strict anti-virus and security requirements that must be met.

\section{Integration Plan to Bridge between Level 1 and 2}

The most effective energy management use of the wireless sensor data requires that it be available to the business decision makers who use only the Level 2 network. The long-term goal is to make real-time data available to the decision maker so that optimum use of all plant assets can be made within the constraints of order flow and overall business state. The ORNL project team and E.T. Plant personnel developed a vision of how the system could be implemented to partially realize that goal. The approach taken was to designate the wireless system as L1W for Level 1 - Wireless and host a server for the wireless data on the Level 2 network. A decision was made in the early stages that it would be most efficient to house the server in an IT main computer room and acquire user licenses for the data acquisition and display software to maximize exposure to the real-time data. Fig. 18 shows how that architecture was envisioned and was included in the solicitation. 


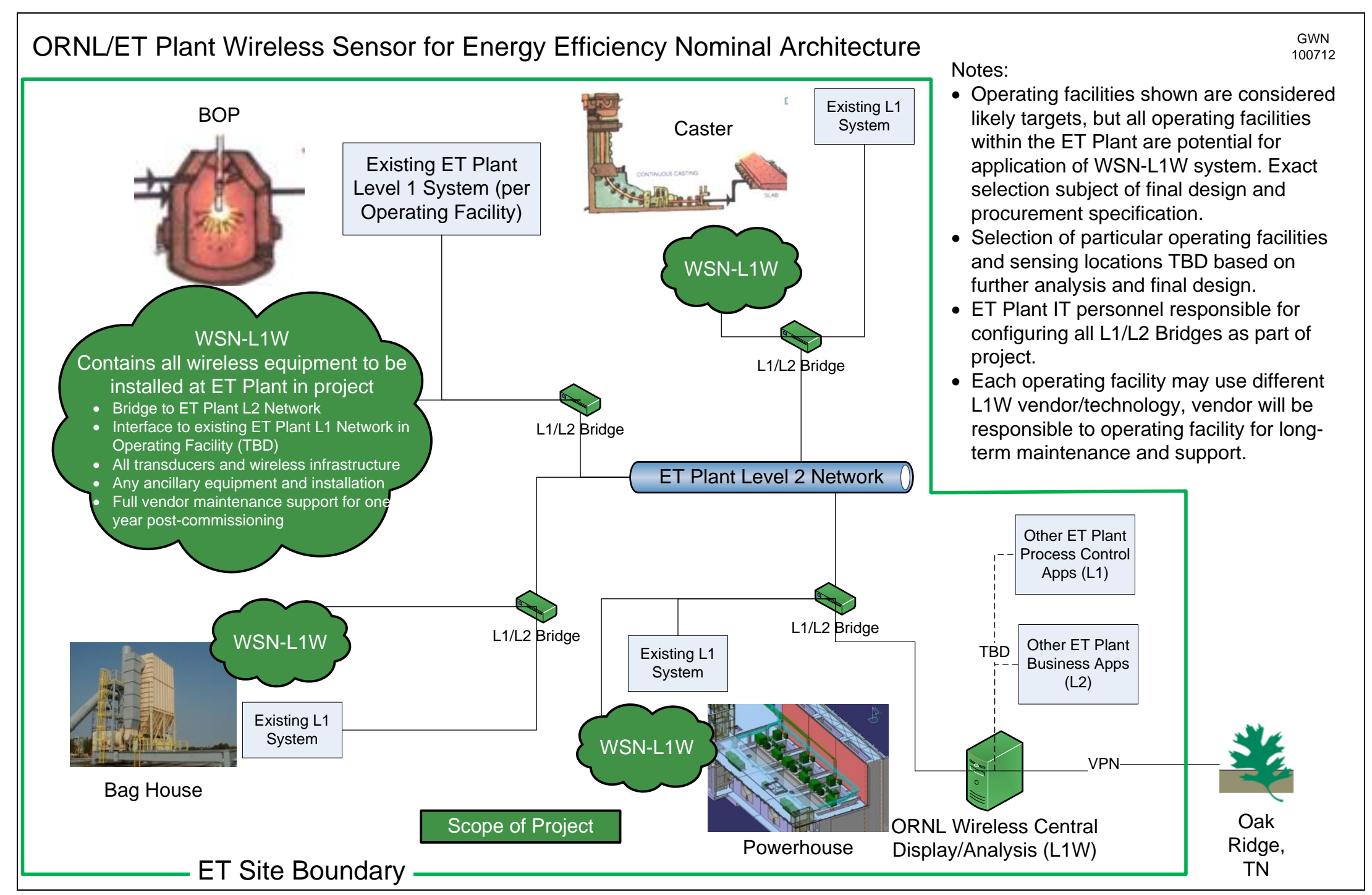

Fig. 18. Integration strategy for energy efficiency wireless sensor network. 
An important item to note on this design is that each operating facility included a bridge between the L1 network (both the newly installed wireless "WSN-L1W" and at least part of the existing L1 network). A prerequisite of the E.T. Plant IT group was that the server and firewall that interface directly to their system comply with their specifications and they are responsible for configuration of those devices. The server and firewall hardware and software specifications for the E.T. Plant were included as Appendix E in the ORNL technical solicitation.

\section{Radio Frequency (RF) Site Survey}

The ORNL project team conducted an RF Site Survey (see Appendices) at the E.T. Plant to better understand the operating environment and to provide technical data to vendors responding to the ORNL solicitation. It should be noted that prior to the ORNL project, an RF survey was conducted by Data Ltd, Inc. - Technical Services and was commissioned by U.S. Steel in preparation for installation of a WiFi-based inventory tracking system in the slab run-out area. The survey was in the $2.4 \mathrm{GHz}$ operating range while the project was concerned with $900 \mathrm{MHz}$ so its technical data weren't used in the project.

The ORNL RF survey covered the entire plant area and all three unlicensed Industrial, Scientific, and Medical (ISM) frequency bands commonly used in current wireless networking technologies. The ISM bands of interest are $902-928 \mathrm{MHz}, 2.4-2.4835 \mathrm{GHz}$ and $5.725-5.875 \mathrm{GHz}$.

The findings of the survey were promising for the project. There did not appear to be any RF interferences that would preclude communications in any of the measured ISM frequency bands. The conclusions of that study included

- The $2.4 \mathrm{GHz}$ band has an average noise floor of $-70 \mathrm{dBm}$.

- Limited areas have $2.4 \mathrm{GHz} 802.11 \mathrm{x}$ networks (see plots for more details).

- The $5.8 \mathrm{GHz}$ band is relatively clean with average noise floor of $-75 \mathrm{dBm}$.

- The $915 \mathrm{MHz}$ band showed no potential interferer and sufficient range.

The ORNL project team worked with E.T. Plant personnel to determine what would advance the steelmaking processes most while still increasing energy efficiency. The results of that collaboration are shown in Table 1. It is a subset of the System Definition table that was included in the solicitation. The most important columns in Table 1 are Criticality (rated priority order for potential impact on energy savings) and Operational Restrictions. 
Table 1. Subset of system definition table (Revision 1) from Appendix B of technical specification in solicitation

\begin{tabular}{|c|c|c|c|c|c|}
\hline Criticality & Process & Process Entity & Measurement Observation & Environmental Stressors & Operational Restrictions \\
\hline \multirow{18}{*}{1} & \multirow{18}{*}{$\begin{array}{c}\# 2 \\
\text { Powerhouse, } \\
\# 1 \text {, \#2 and \#3 } \\
\text { Boiler } \\
\text { Efficiency } \\
\text { Monitoring } \\
\text { and } \\
\text { Improvemen } \\
\text { t }\end{array}$} & \multirow{15}{*}{$\begin{array}{l}\text { Boilers in \#2 } \\
\text { Powerhouse }\end{array}$} & Coke Oven Gas Flow & Heat $\sim 130$ F, Dirt. & $\begin{array}{l}\text { May be able tap off current probe, if not boiler must be } \\
\text { down. }\end{array}$ \\
\hline & & & Coke Oven Gas BTU & Heat $130 \mathrm{~F}$, Dirt. & Boiler will need to be down. \\
\hline & & & Blast Furnace Gas Flow to boiler & Heat $\sim 130$ F, Dirt. & $\begin{array}{l}\text { May be able tap off current probe, if not boiler must be } \\
\text { down. }\end{array}$ \\
\hline & & & Blast Furnace Gas BTU & Heat $130 \mathrm{~F}$, Dirt. & Boiler will need to be down. \\
\hline & & & Center Pilot Gas Flow & Heat $\sim 130$ F, Dirt. & $\begin{array}{l}\text { May be able tap off current probe, if not boiler must be } \\
\text { down. }\end{array}$ \\
\hline & & & Feed Water Temperature & Heat $130 \mathrm{~F}$, Dirt, Water & $\begin{array}{l}\text { May be able tap off current probe, if not boiler may need } \\
\text { to be down. }\end{array}$ \\
\hline & & & Feedwater Flow & Heat $\sim 130 \mathrm{~F}$, Dirt, Water. & $\begin{array}{l}\text { May be able tap off current probe, if not boiler must be } \\
\text { down. }\end{array}$ \\
\hline & & & Economizer Inlet Temperature & Heat $130 \mathrm{~F}$, Dirt. & Most likely can be installed during normal operation. \\
\hline & & & Economizer Outlet Temperature & Heat $\sim 130 \mathrm{~F}$, Dirt. & Most likely can be installed during normal operation. \\
\hline & & & Preheater Inlet Temperature & Heat $\sim 130 \mathrm{~F}$, Dirt. & Most likely can be installed during normal operation. \\
\hline & & & Preheater Outlet Temperature & Heat $\sim 130$ F, Dirt. & Most likely can be installed during normal operation. \\
\hline & & & Combustion Air Inlet Flow & Heat 130 F, Dirt. & $\begin{array}{l}\text { May be able tap off current probe, if not boiler must be } \\
\text { down. }\end{array}$ \\
\hline & & & Steam Flow & Heat $\sim 130$ F, Dirt, Steam. & $\begin{array}{l}\text { May be able tap off current probe, if not boiler must be } \\
\text { down. }\end{array}$ \\
\hline & & & Steam Temperature & Heat $\sim 130$ F, Dirt, Steam. & $\begin{array}{l}\text { May be able tap off current probe, if not boiler must be } \\
\text { down. }\end{array}$ \\
\hline & & & Steam Pressure Meter & Heat $\sim 130$ F, Dirt, Steam. & Boiler will need to be down. \\
\hline & & \multirow{3}{*}{ Exhaust Stack } & Stack Temperature & Heat, Dirt. & Most likely can be installed during normal operation. \\
\hline & & & Stack Oxygen Probe & Heat, Dirt. & Most likely can be installed during normal operation. \\
\hline & & & Stack Flow & Heat, Dirt. & Most likely can be installed during normal operation. \\
\hline 2 & $\begin{array}{l}\text { BOP Shop Air } \\
\text { Quality }\end{array}$ & $\begin{array}{l}\text { Top of BOP } \\
\text { Shop }\end{array}$ & Opacity meter in BOP Shop & Heat 130 F, Dirt. & Can be installed during normal operations. \\
\hline \multirow{2}{*}{3} & \multirow{2}{*}{$\begin{array}{c}\text { BOP Gas } \\
\text { Cleaning A \& } \\
\text { B Stack }\end{array}$} & \multirow{2}{*}{$\begin{array}{l}\text { BOP ID Fan } \\
\text { Stacks }\end{array}$} & Opacity Meter & Heat $\sim 130$ F, Dirt, weather. & $\begin{array}{l}\text { AC power available. Fan can be shut down one at a time to } \\
\text { install equipment. }\end{array}$ \\
\hline & & & Flow Meter & Heat $\sim 130$ F, Dirt, weather. & $\begin{array}{l}\text { AC power available. Fan can be shut down one at a time to } \\
\text { install equipment. }\end{array}$ \\
\hline \multirow{2}{*}{4} & \multirow{2}{*}{$\begin{array}{l}\text { \#2 Power } \\
\text { House } \\
\text { Blower } \\
\text { Efficiency }\end{array}$} & \multirow{2}{*}{$\begin{array}{l}\text { Blowers in \#2 } \\
\text { Powerhouse }\end{array}$} & Steam Mass Flow, Actual Flow & Heat $\sim 130$ F, Dirt, Steam. & $\begin{array}{l}\text { Must work with \#2 Powerhouse personnel to schedule } \\
\text { installation. }\end{array}$ \\
\hline & & & Steam Temperatures & Heat $\sim 130$ F, Dirt, Steam. & $\begin{array}{l}\text { Must work with \#2 Powerhouse personnel to schedule } \\
\text { installation. }\end{array}$ \\
\hline
\end{tabular}




\begin{tabular}{|c|c|c|c|c|c|}
\hline Criticality & Process & Process Entity & Measurement Observation & Environmental Stressors & Operational Restrictions \\
\hline & & & Steam Pressure & Heat $\sim 130$ F, Dirt, Steam. & $\begin{array}{l}\text { Must work with \#2 Powerhouse personnel to schedule } \\
\text { installation. }\end{array}$ \\
\hline & & & Inlet Air Flow D/P & Heat 130 F, Dirt. & $\begin{array}{l}\text { Must work with \#2 Powerhouse personnel to schedule } \\
\text { installation. }\end{array}$ \\
\hline & & & Inlet Air Pressure & Heat $\sim 130 \mathrm{~F}$, Dirt. & $\begin{array}{l}\text { Must work with \#2 Powerhouse personnel to schedule } \\
\text { installation. }\end{array}$ \\
\hline & & & Inlet Air Temperature & Heat $130 \mathrm{~F}$, Dirt. & $\begin{array}{l}\text { Must work with \#2 Powerhouse personnel to schedule } \\
\text { installation. }\end{array}$ \\
\hline & & & Local Outlet Air Flow D/P & Heat $130 \mathrm{~F}$, Dirt. & $\begin{array}{l}\text { Must work with \#2 Powerhouse personnel to schedule } \\
\text { installation. }\end{array}$ \\
\hline & & & Local Outlet Air Pressure & Heat 130 F, Dirt. & $\begin{array}{l}\text { Must work with \#2 Powerhouse personnel to schedule } \\
\text { installation. }\end{array}$ \\
\hline & & & Local Outlet Air Temperature & Heat $\sim 130 \mathrm{~F}$, Dirt. & $\begin{array}{l}\text { Must work with \#2 Powerhouse personnel to schedule } \\
\text { installation. }\end{array}$ \\
\hline & & & Outlet Air Flow at Blast Furnace & Heat 130 F, Dirt. & $\begin{array}{l}\text { Must work with \#2 Powerhouse personnel to schedule } \\
\text { installation. }\end{array}$ \\
\hline \multirow[b]{2}{*}{5} & \multirow{2}{*}{$\begin{array}{c}\text { Caster Torch } \\
\text { Nozzle } \\
\text { Efficiency } \\
\end{array}$} & \multirow[b]{2}{*}{ Caster Torch } & Oxygen Flow & Heat $\sim 130 \mathrm{~F}$, Dirt. & AC Power available. Must be installed on downturn. \\
\hline & & & Gas Flow & Heat 130 F, Dirt. & AC Power available. Must be installed on downturn. \\
\hline \multirow[b]{2}{*}{6} & \multirow{2}{*}{$\begin{array}{l}\text { Individual } \\
\text { Metering for } \\
\text { the Seven } \\
\text { BOP } \\
\text { Preheaters }\end{array}$} & \multirow[b]{2}{*}{ At Preheater } & Natural Gas Flow & Heat $130 \mathrm{~F}$, Dirt. & $\begin{array}{l}\text { AC Power Available. Preheater can be shut down during } \\
\text { normal operation to install equipment. }\end{array}$ \\
\hline & & & Coke Gas Flow & Heat $130 \mathrm{~F}$, Dirt. & $\begin{array}{l}\text { AC Power Available. Preheaters can be shut down one at a } \\
\text { time during normal operation to install equipment. }\end{array}$ \\
\hline \multirow{4}{*}{7} & \multirow{4}{*}{$\begin{array}{l}\text { Compressor } \\
\text { Loading } \\
\text { Distribution } \\
\text { Efficiency } \\
\text { focusing on } \\
\text { Caster Air } \\
\text { Mist and } \\
\text { Instrument } \\
\text { Air } \\
\text { Compressors }\end{array}$} & \multirow{2}{*}{ All Compressors } & Air Flow from each compressor & Heat $130 \mathrm{~F}$, Dirt. & $\begin{array}{l}\text { AC Power available. Compressors can be shut down one at } \\
\text { a time during normal operations to install equipment. }\end{array}$ \\
\hline & & & Pressure from each compressor & Heat $130 \mathrm{~F}$, Dirt. & $\begin{array}{l}\text { AC Power available. Compressors can be shut down one at } \\
\text { a time during normal operations to install equipment. }\end{array}$ \\
\hline & & \multirow[b]{2}{*}{$\begin{array}{l}\text { various } \\
\text { locations }\end{array}$} & $\begin{array}{l}\text { Pressure from various points in } \\
\text { the plant }\end{array}$ & Heat $130 \mathrm{~F}$, Dirt, weather. & Some locations lack plug in power. \\
\hline & & & $\begin{array}{l}\text { Flow from various points in the } \\
\text { plant }\end{array}$ & Heat 130 F, Dirt, weather. & Some locations lack plug in power. \\
\hline 8 & $\begin{array}{l}\text { Nitrogen } \\
\text { Main Gas } \\
\text { Line }\end{array}$ & $\begin{array}{l}\text { Main Nitrogen } \\
\text { Lines }\end{array}$ & High Pressure Flow Meters & Heat $130 \mathrm{~F}$, Dirt, weather. & AC power not available. Must be done during downturn. \\
\hline 9 & $\begin{array}{l}\text { Natural Gas } \\
\text { Usage }\end{array}$ & $\begin{array}{l}\text { Main Natural } \\
\text { Gas Line }\end{array}$ & Main Line Flow & Heat $130 \mathrm{~F}$, Dirt, weather. & Must be done during outage. \\
\hline
\end{tabular}




\begin{tabular}{|c|c|c|c|c|c|}
\hline Criticality & Process & Process Entity & Measurement Observation & Environmental Stressors & Operational Restrictions \\
\hline & & $\begin{array}{l}\text { Various } \\
\text { locations }\end{array}$ & Individual Consumer Flows & Heat $\sim 130$ F, Dirt, weather. & Some locations lack plug in power. \\
\hline \multirow{4}{*}{10} & \multirow{4}{*}{$\begin{array}{c}\text { BOP Gas } \\
\text { Cleaning A\&B } \\
\text { ID Fan } \\
\text { Motors and } \\
\text { Fan } \\
\text { Efficiency }\end{array}$} & \multirow{3}{*}{$\begin{array}{l}\text { BOP ID Fan } \\
\text { Motor }\end{array}$} & Motor Current & Heat $\sim 130$ F, Dirt, weather. & $\begin{array}{l}\text { AC power available. Fans can be shut down one at a time } \\
\text { during normal operation to install equipment. }\end{array}$ \\
\hline & & & Motor RPM & Heat 130 F, Dirt, weather. & $\begin{array}{l}\text { AC power available. Fans can be shut down one at a time } \\
\text { during normal operation to install equipment. }\end{array}$ \\
\hline & & & Stator Temperature & Heat $\sim 130$ F, Dirt, weather. & $\begin{array}{l}\text { AC power available. Fans can be shut down one at a time } \\
\text { during normal operation to install equipment. }\end{array}$ \\
\hline & & BOP ID Fan & Fan RPM & Heat $\sim 130$ F, Dirt, weather. & $\begin{array}{l}\text { AC power available. Fans can be shut down one at a time } \\
\text { during normal operation to install equipment. }\end{array}$ \\
\hline \multirow{3}{*}{11} & \multirow{3}{*}{$\begin{array}{l}\text { BOP "F" and } \\
\text { "R" Duct } \\
\text { Flow }\end{array}$} & \multirow{3}{*}{$\begin{array}{l}\text { Duct work for } \\
\text { "R" and "F" } \\
\text { Furnace. }\end{array}$} & Air Flow & & $\begin{array}{l}\text { Ac power available. Depending on how long it takes to } \\
\text { install equipment, it may be possible to arrange production } \\
\text { schedule to install equipment. }\end{array}$ \\
\hline & & & Air Pressure & & $\begin{array}{l}\text { Ac power available. Depending on how long it takes to } \\
\text { install equipment, it may be possible to arrange production } \\
\text { schedule to install equipment. }\end{array}$ \\
\hline & & & Air Temperature & & $\begin{array}{l}\text { Ac power available. Depending on how long it takes to } \\
\text { install equipment, it may be possible to arrange production } \\
\text { schedule to install equipment. }\end{array}$ \\
\hline 12 & $\begin{array}{l}\text { BOP Gas } \\
\text { Clearing } \\
\text { Open Loop } \\
\text { Make Up } \\
\text { Water } \\
\text { Tracking } \\
\end{array}$ & $\begin{array}{l}\text { Various Make } \\
\text { up water flow } \\
\text { meters. }\end{array}$ & $\begin{array}{l}\text { Flow meters for makeup water } \\
\qquad \text { lines }\end{array}$ & & $\begin{array}{l}\text { Depending on installation time, probe could be installed at } \\
\text { any time. }\end{array}$ \\
\hline \multirow{3}{*}{13} & \multirow{3}{*}{$\begin{array}{l}\text { Degasser } \\
\text { Steam Flow }\end{array}$} & \multirow{3}{*}{ Degasser } & Steam Flow & Heat $\sim 130$ F, Dirt, Steam. & $\begin{array}{l}\text { AC power available. Must be installed when Degasser is not } \\
\text { in operation. }\end{array}$ \\
\hline & & & Steam Temperature & Heat $\sim 130$ F, Dirt, Steam. & $\begin{array}{l}\text { AC power available. Must be installed when Degasser is not } \\
\text { in operation. }\end{array}$ \\
\hline & & & Steam Pressure & Heat $\sim 130$ F, Dirt, Steam. & $\begin{array}{l}\text { AC power available. Must be installed when Degasser is not } \\
\text { in operation. }\end{array}$ \\
\hline 14 & $\begin{array}{l}\text { Mixer Bag } \\
\text { House } \\
\text { Efficiency }\end{array}$ & $\begin{array}{l}\text { Mixer Baghouse } \\
\text { Compartments }\end{array}$ & Air Flows & Heat 130 F, Dirt, weather. & $\begin{array}{l}\text { AC power available. Vendor to determine if the meters can } \\
\text { be installed while the baghouse is operating. If not } \\
\text { downturn required. }\end{array}$ \\
\hline 15 & $\begin{array}{l}\text { Fugitive Bag } \\
\text { House } \\
\text { Efficiency }\end{array}$ & $\begin{array}{c}\text { Fugitive } \\
\text { Baghouse } \\
\text { Compartments } \\
\end{array}$ & Air Flows & Heat $\sim 130$ F, Dirt, weather. & $\begin{array}{l}\text { AC power available. Vendor to determine if the meters can } \\
\text { be installed while the baghouse is operating. If not } \\
\text { downturn required. }\end{array}$ \\
\hline 16 & $\begin{array}{l}\text { Blast Furnace } \\
\text { Bag House } \\
\text { Efficiency }\end{array}$ & $\begin{array}{l}\text { Blast Furnace } \\
\text { Baghouse } \\
\text { Compartments }\end{array}$ & Air Flows & Heat 130 F, Dirt, weather. & $\begin{array}{l}\text { AC power available. Vendor to determine if the meters can } \\
\text { be installed while the baghouse is operating. If not } \\
\text { downturn required. }\end{array}$ \\
\hline
\end{tabular}




\begin{tabular}{|c|c|c|c|c|c|}
\hline Criticality & Process & Process Entity & Measurement Observation & Environmental Stressors & Operational Restrictions \\
\hline 17 & $\begin{array}{c}\text { Chem Treat } \\
\text { Water } \\
\text { Systems }\end{array}$ & $\begin{array}{l}\text { Various Water } \\
\text { systems }\end{array}$ & ORP Probes & Heat $~ 130 ~ F$, Dirt, weather. & \\
\hline 18 & $\begin{array}{l}\text { Cooling } \\
\text { Tower fan } \\
\text { Vibration }\end{array}$ & Cooling Towers & Vibration Probes & Heat 130 F, Dirt, weather. & AC power available. Downturn required. \\
\hline \multirow{4}{*}{19} & \multirow{4}{*}{$\begin{array}{c}\text { \#2 } \\
\text { Powerhouse } \\
\text { Main } \\
\text { Generator } \\
\text { Efficiency }\end{array}$} & \multirow{4}{*}{$\begin{array}{c}\text { Main } \\
\text { Generators }\end{array}$} & Steam Mass Flow, Actual Flow & Heat $\sim 130$ F, Dirt, Steam. & $\begin{array}{l}\text { Must work with \#2 Powerhouse personnel to schedule } \\
\text { installation. }\end{array}$ \\
\hline & & & Steam Temperatures & Heat $\sim 130$ F, Dirt, Steam. & $\begin{array}{l}\text { Must work with \#2 Powerhouse personnel to schedule } \\
\text { installation. }\end{array}$ \\
\hline & & & Steam Pressure & Heat $\sim 130$ F, Dirt, Steam. & $\begin{array}{l}\text { Must work with \#2 Powerhouse personnel to schedule } \\
\text { installation. }\end{array}$ \\
\hline & & & Power Output & Heat $130 \mathrm{~F}$, Dirt. & $\begin{array}{l}\text { Must work with \#2 Powerhouse personnel to schedule } \\
\text { installation. }\end{array}$ \\
\hline \multirow{6}{*}{20} & \multirow{6}{*}{$\begin{array}{l}\text { "NEW" Blue } \\
\text { River Pump } \\
\text { House Motor } \\
\text { and Pump } \\
\text { Efficiency }\end{array}$} & \multirow{3}{*}{$\begin{array}{l}\text { River Pump } \\
\text { House Motor }\end{array}$} & Motor RPM & Heat $130 \mathrm{~F}$, Dirt. & $\begin{array}{l}\text { AC power available. Pumps can be shut down one at a time } \\
\text { during normal operation to install equipment. }\end{array}$ \\
\hline & & & Motor Stator Temperature & Heat $\sim 130 \mathrm{~F}$, Dirt. & $\begin{array}{l}\text { AC power available. Pumps can be shut down one at a time } \\
\text { during normal operation to install equipment. }\end{array}$ \\
\hline & & & Motor Vibration & Heat $130 \mathrm{~F}$, Dirt. & $\begin{array}{l}\text { AC power available. Pumps can be shut down one at a time } \\
\text { during normal operation to install equipment. }\end{array}$ \\
\hline & & $\begin{array}{l}\text { River Pump } \\
\text { House Pump }\end{array}$ & Pump Vibration & Heat $130 \mathrm{~F}$, Dirt. & $\begin{array}{l}\text { AC power available. Pumps can be shut down one at a time } \\
\text { during normal operation to install equipment. }\end{array}$ \\
\hline & & \multirow{2}{*}{$\begin{array}{l}\text { River Pump } \\
\text { House Water } \\
\text { Pipes }\end{array}$} & Water Flow & Heat $~ 130 ~ F$, Dirt, Water & AC power available. Downturn required. \\
\hline & & & Water Pressure & Heat $130 \mathrm{~F}$, Dirt, Water & AC power available. Downturn required. \\
\hline
\end{tabular}


The system installed by Andrews had both high and moderate priority level assignments. The system provided measurements (e.g. temperature and pressure) in addition to what was requested as well as calculations. Table 2 represents the installation by Andrews and is an excerpt of Table 1, which is based on the system definition table provided in the solicitation.

Table 2. Installed sensors as represented in subset of system definition table (from Appendix B of solicitation)

\begin{tabular}{|c|c|c|c|c|c|}
\hline Criticality & Process & Process Entity & Measurement Observation & $\begin{array}{c}\text { Environmental } \\
\text { Stressors } \\
\end{array}$ & $\begin{array}{l}\text { Operational } \\
\text { Restrictions }\end{array}$ \\
\hline \multirow{8}{*}{1} & \multirow{8}{*}{$\begin{array}{c}\# 2 \text { Powerhouse, } \\
\# 1, \# 2 \text { and \#3 } \\
\text { Boiler Efficiency } \\
\text { Monitoring and } \\
\text { Improvement } \\
\text { (instrumented } \\
\text { Boiler \#3 only) }\end{array}$} & \multirow{8}{*}{$\begin{array}{l}\text { Boilers in \#2 } \\
\text { Powerhouse } \\
\text { (instrumented } \\
\text { Boiler \#3 only) }\end{array}$} & $\begin{array}{l}\text { Coke Oven Gas Flow (also } \\
\text { measured pressure and } \\
\text { temperature) }\end{array}$ & $\begin{array}{l}\text { Heat } \sim 130 \mathrm{~F}, \\
\text { Dirt. }\end{array}$ & $\begin{array}{l}\text { May be able tap off } \\
\text { current probe, if not } \\
\text { boiler must be down. }\end{array}$ \\
\hline & & & $\begin{array}{l}\text { Coke Oven Gas BTU } \\
\text { (calculated SCFM and } \\
\text { BTU/min) }\end{array}$ & $\begin{array}{c}\text { Heat } \sim 130 \mathrm{~F}, \\
\text { Dirt. }\end{array}$ & $\begin{array}{l}\text { Boiler will need to be } \\
\text { down. }\end{array}$ \\
\hline & & & $\begin{array}{l}\text { Blast Furnace Gas Flow to } \\
\text { boiler (also measured } \\
\text { pressure and temperature) }\end{array}$ & $\begin{array}{l}\text { Heat } \sim 130 \mathrm{~F}, \\
\text { Dirt. }\end{array}$ & $\begin{array}{l}\text { May be able tap off } \\
\text { current probe, if not } \\
\text { boiler must be down. }\end{array}$ \\
\hline & & & $\begin{array}{l}\text { Blast Furnace Gas BTU } \\
\text { (calculated SCFM and } \\
\text { BTU/min) }\end{array}$ & $\begin{array}{c}\text { Heat } \sim 130 \mathrm{~F}, \\
\text { Dirt. }\end{array}$ & $\begin{array}{l}\text { Boiler will need to be } \\
\text { down. }\end{array}$ \\
\hline & & & $\begin{array}{l}\text { Economizer Inlet } \\
\text { Temperature }\end{array}$ & $\begin{array}{l}\text { Heat } \sim 130 \mathrm{~F}, \\
\text { Dirt. }\end{array}$ & $\begin{array}{l}\text { Most likely can be } \\
\text { installed during normal } \\
\text { operation. }\end{array}$ \\
\hline & & & $\begin{array}{l}\text { Economizer Outlet } \\
\text { Temperature }\end{array}$ & $\begin{array}{l}\text { Heat } \sim 130 \mathrm{~F}, \\
\text { Dirt. }\end{array}$ & $\begin{array}{l}\text { Most likely can be } \\
\text { installed during normal } \\
\text { operation. }\end{array}$ \\
\hline & & & $\begin{array}{l}\text { Preheater Inlet } \\
\text { Temperature }\end{array}$ & $\begin{array}{c}\text { Heat } \sim 130 \mathrm{~F}, \\
\text { Dirt. }\end{array}$ & $\begin{array}{l}\text { Most likely can be } \\
\text { installed during normal } \\
\text { operation. }\end{array}$ \\
\hline & & & $\begin{array}{l}\text { Preheater Outlet } \\
\text { Temperature }\end{array}$ & $\begin{array}{c}\text { Heat } \sim 130 \mathrm{~F}, \\
\text { Dirt. }\end{array}$ & $\begin{array}{l}\text { Most likely can be } \\
\text { installed during normal } \\
\text { operation. }\end{array}$ \\
\hline 6 & $\begin{array}{c}\text { Individual } \\
\text { Metering for the } \\
\text { Seven BOP } \\
\text { Preheaters } \\
\text { (instrumented } \\
\text { two [2] } \\
\text { Preheaters: } \\
\text { Davey } 1 \text { and } \\
\text { Davey 3) }\end{array}$ & At preheater & $\begin{array}{l}\text { Coke Gas Flow (also } \\
\text { measured pressure and } \\
\text { temperature) (calculated } \\
\text { SCFM and BTU/min) }\end{array}$ & $\begin{array}{l}\text { Heat } \sim 130 \mathrm{~F}, \\
\text { Dirt. }\end{array}$ & $\begin{array}{l}\text { AC Power Available. } \\
\text { Preheaters can be shut } \\
\text { down one at a time } \\
\text { during normal } \\
\text { operation to install } \\
\text { equipment. }\end{array}$ \\
\hline
\end{tabular}


All equipment was installed by early November 2010. Table 3 represents all major equipment (computers, sensors and radios) installed by Andrews.

Table 3. Major equipment installed by Andrews

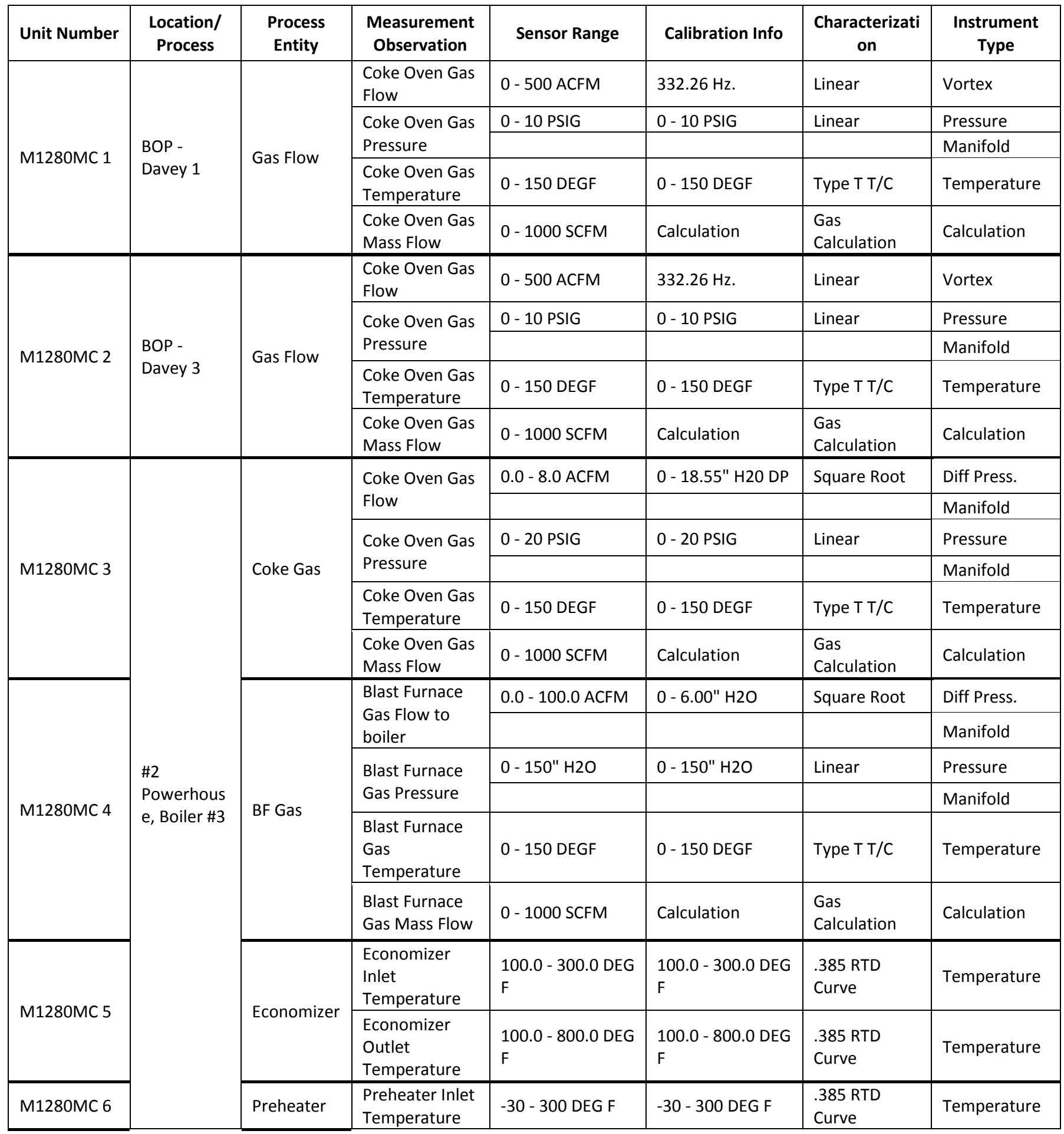




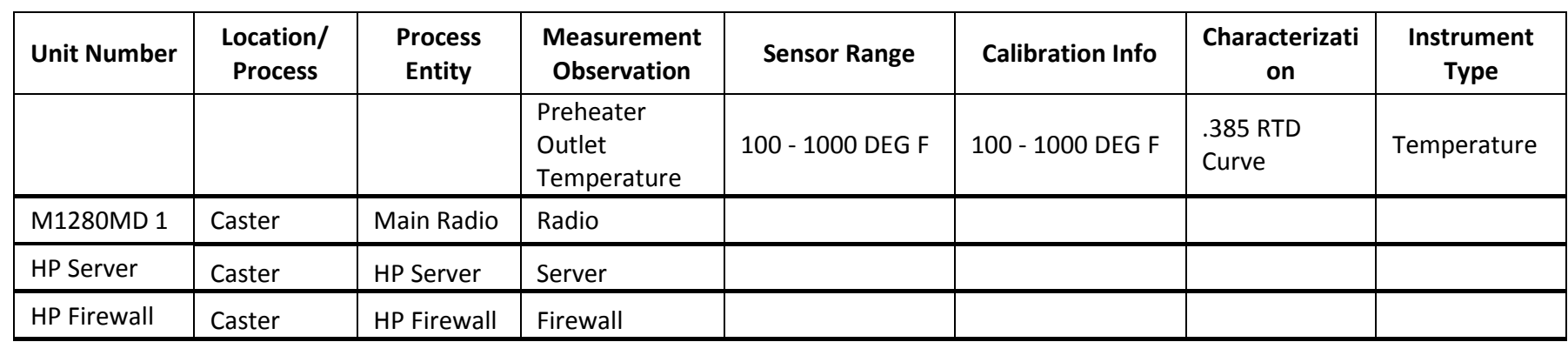

The E.T. Plant is comprised of multiple facilities in a large space. An aerial view of the E.T. Plant is provided in Fig. 19 to show the size of the mill and the specific locations of the installed equipment. This view offers a relationship between the monitored processes to the main radio unit and the wireless system to the rest of the mill.

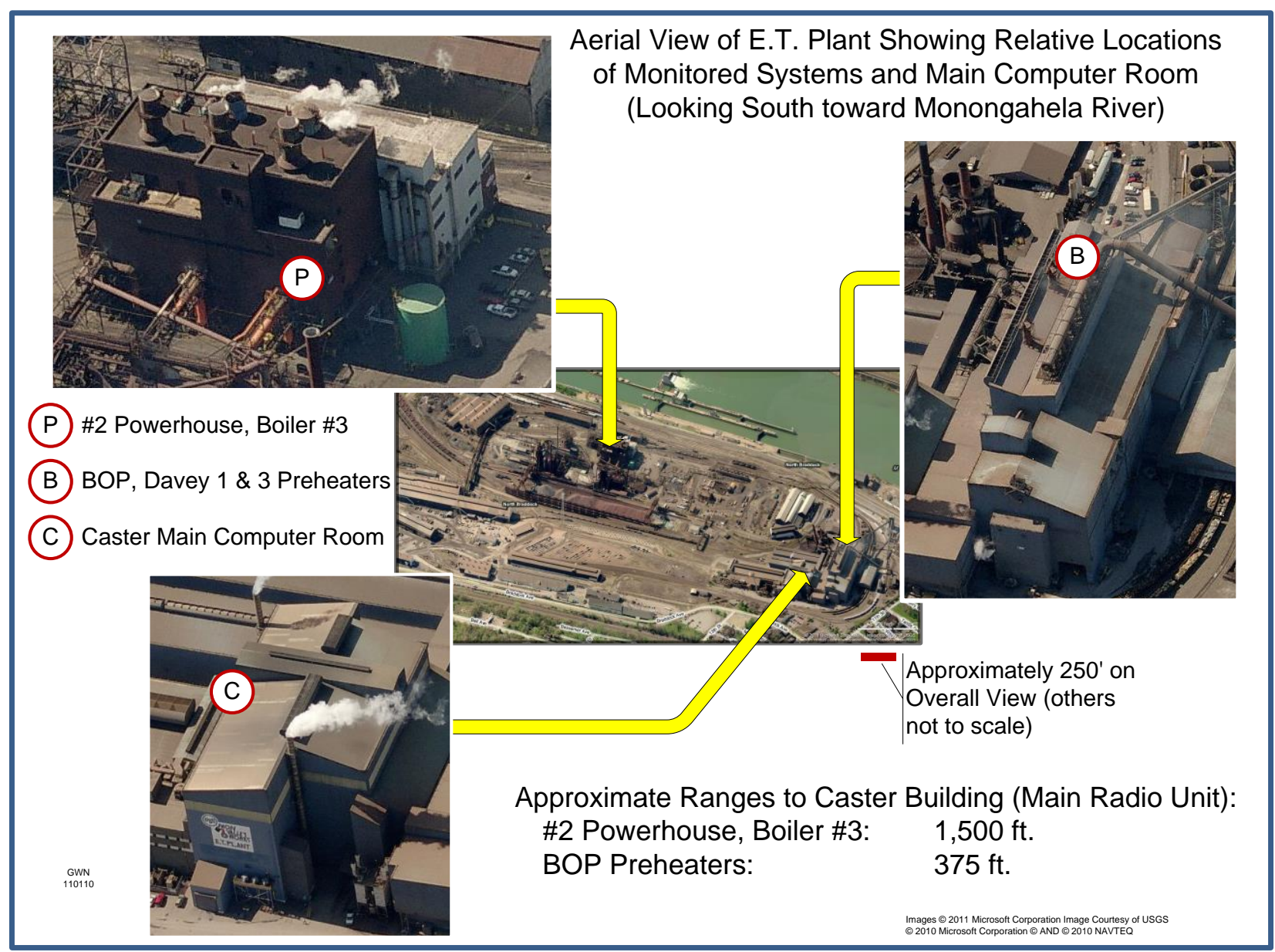

Fig. 19. Aerial view of wireless monitoring system installation at E.T. Plant.

Four of the six installations by Andrews measure temperature, flow and pressure. Fig. 20 shows representative sensors in the Plant. Photos of individual sensors placed by Andrews at the E.T. Plant can be found in the Appendices. 


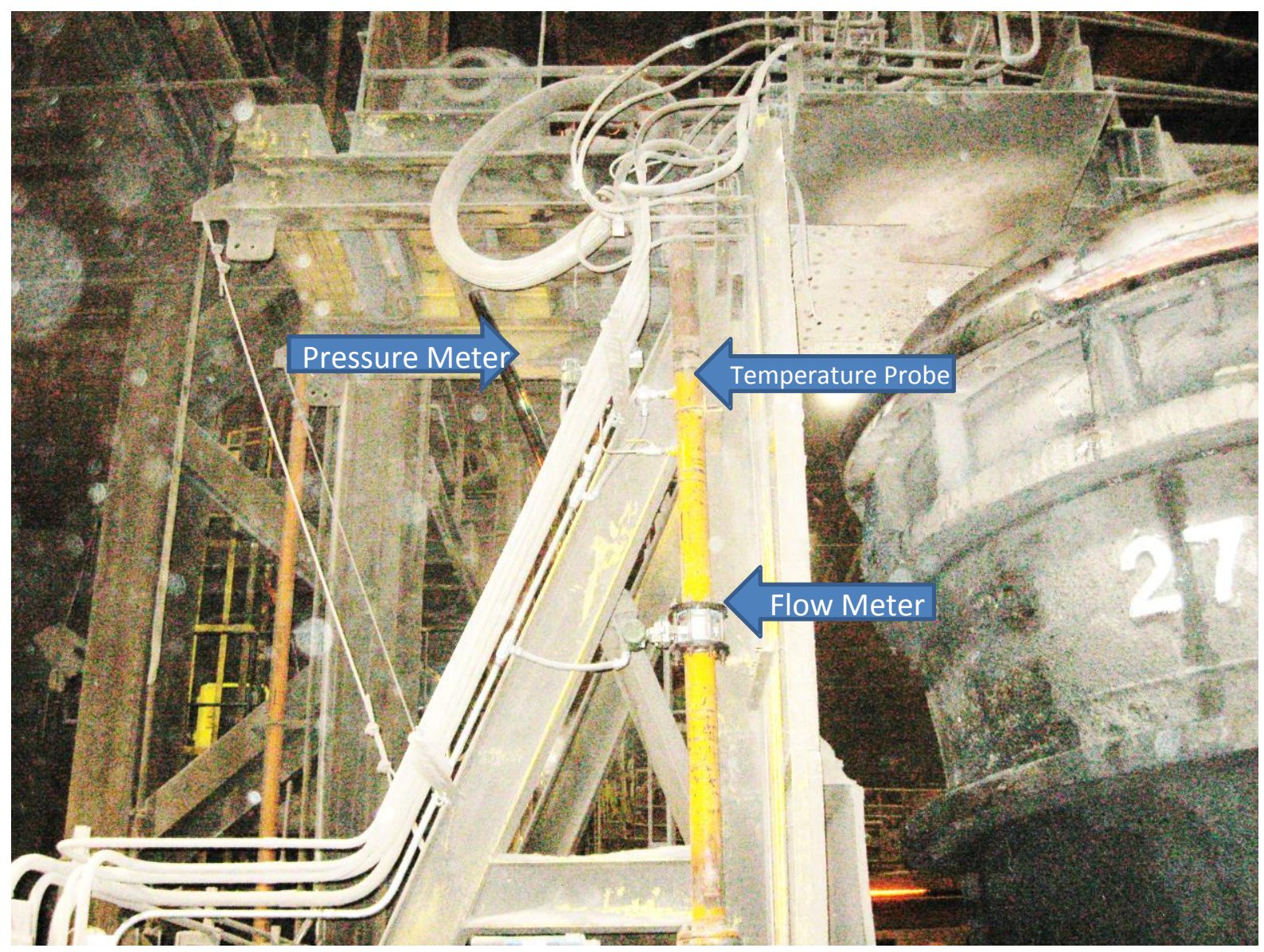

Fig. 20. Wireless monitoring in the E.T. Plant.

On November 4, 2010, Andrews configured all of the radio units, antennas and sensors; ensured all sensors were monitoring and producing data; checked that fault detection safeguards were in place and working; installed the server with security and data collection software; and established a graphical user interface (GUI) for easy monitoring by U.S. Steel, ORNL, and Andrews. Andrews completed the installation ahead of schedule. All work complied with U.S. Steel and E.T. Plant standards and was well coordinated with plant personnel. No issues were reported by either party during installation.

\section{Monitored Processes}

The wireless system installed by Andrews captures data for measurements in the BOB Preheaters and the Powerhouse boilers, two major steps that support the steelmaking process: the Basic Oxygen Processing (BOP) and the Blast Furnace. Within the BOP, two of the preheaters (referred to as Davey 1 and Davey 3) have new wireless sensors installed to measure flow, pressure, and temperature of Coke Oven Gas. Based on these measurements, Coke Oven Gas Mass Flow is calculated. 
U.S. Steel listed installations on boilers in the \#2 Powerhouse as a number one priority. So the same types of sensors used in the BOP are installed and same calculation is made for Coke Oven Gas Flow and Blast Furnace Gas flow to the \#3 Boiler in the \#2 Powerhouse. For the same boiler, inlet and outlet temperatures for the preheater and economizer are also monitored.

The entire system consists of six remote field radio I/O units (two in the BOP and four in the \#2 Powerhouse) that measure various process parameters and transmit the measured data wirelessly to a main receiving radio unit. The main radio unit is equipped with a data acquisitioning device (MW100) that stores the data into the appropriate storage registers. These data are then sent to a designated server located in the Caster for long-term storage and dissemination to various required users (U.S. Steel, ORNL, and Andrews). Data can be accessed via a virtual private network (VPN) for remote monitoring and system diagnostics using DAQWORX software.

The sensors selected for the wireless energy monitoring system represented a good demonstration opportunity that could yield measurable results within the constraints of time, money, and technology. Fig. 21 and Table 4 represent the installed system at the E.T. Plant. Fig. 21 is a diagram summarizing the system architecture by indicating sensor type, sensor to radio connectivity, radio to network connectivity, etc.

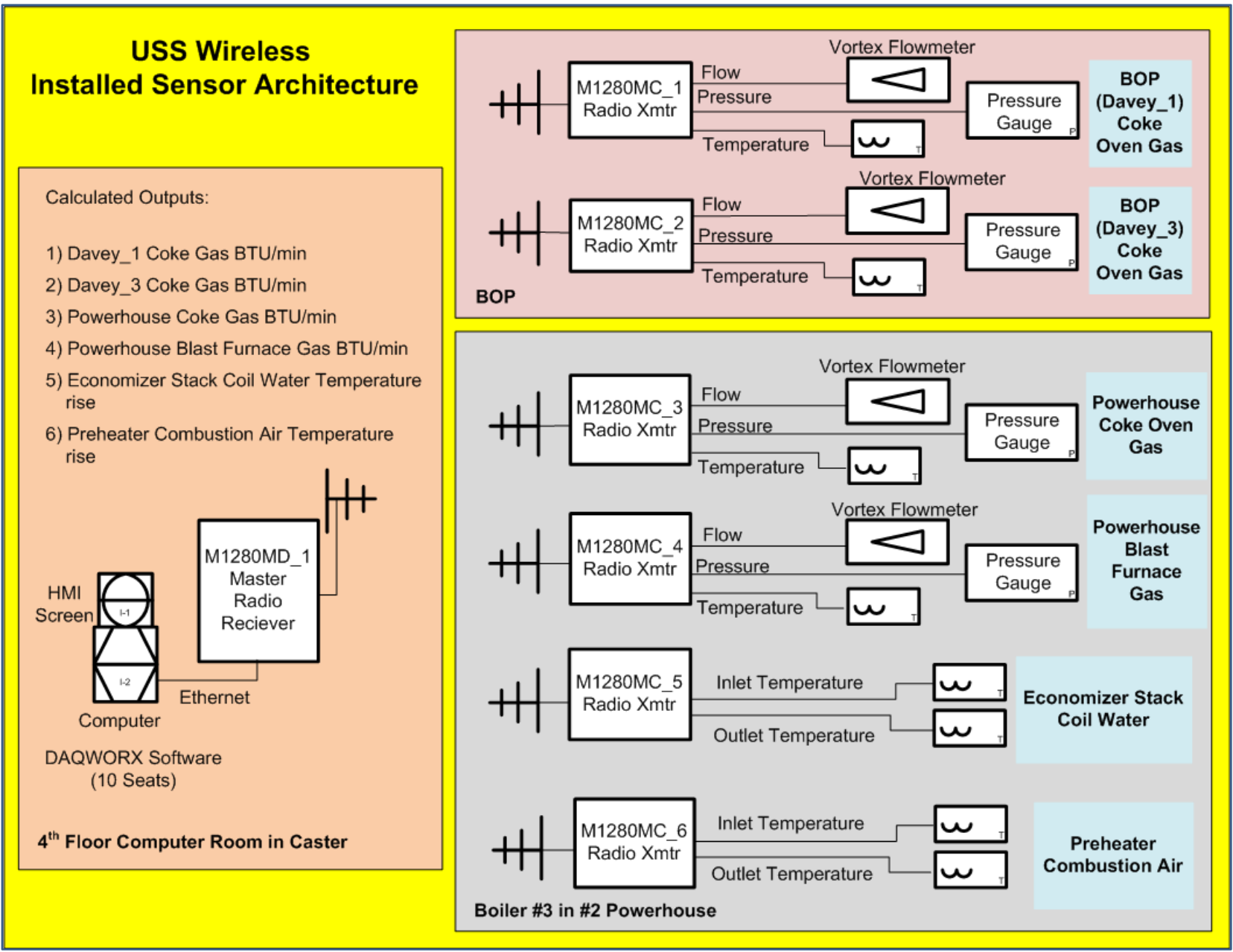

Fig. 21. Architecture overview of wireless monitoring system at E.T. Plant. 
Table 4 augments the diagram by adding the operational range of each installed sensor in the system. This information is critical for monitoring data collected by the system. When reviewing the data, each sensor and radio unit is associated with a channel, which is listed in Table 4. Observers of the data are alerted to any readings above/below the operational range. When such an observation is made, an explanation is sought to ensure the sensors and radios are working properly and are not at fault in any way.

Table 4. Operational ranges of sensors in wireless monitoring system at E.T. Plant

\begin{tabular}{|c|c|c|c|c|}
\hline Location/Process & Process Entity & Measurement Observation & Operational Range & Channel \\
\hline Caster & Main Radio Unit & Radio & on/off & \\
\hline Caster & HP Server & Server & on/off & $n / a$ \\
\hline Caster & HP Firewall & Firewall & on/off & $n / a$ \\
\hline \multirow{6}{*}{ BOP - Davey 1} & \multirow{6}{*}{ Gas Flow } & Coke Oven Gas Flow & $0-250$ ACFM & 101 \\
\hline & & Coke Oven Gas Pressure & 0 - 5 PSIG & 102 \\
\hline & & Coke Oven Gas Temperature & 30-80 DEGF & 103 \\
\hline & & Coke Oven Gas Mass Flow & $0-300$ SCFM & 104 \\
\hline & & Radio & on/off & 121 \\
\hline & & Antenna & $\mathrm{n} / \mathrm{a}$ & $\mathrm{n} / \mathrm{a}$ \\
\hline \multirow{6}{*}{ BOP - Davey 3} & \multirow{6}{*}{ Gas Flow } & Coke Oven Gas Flow & $0-250$ ACFM & 105 \\
\hline & & Coke Oven Gas Pressure & 0 - 5 PSIG & 106 \\
\hline & & Coke Oven Gas Temperature & 30-80 DEGF & 107 \\
\hline & & Coke Oven Gas Mass Flow & $0-300$ SCFM & 108 \\
\hline & & Radio & on/off & 122 \\
\hline & & Antenna & $\mathrm{n} / \mathrm{a}$ & $\mathrm{n} / \mathrm{a}$ \\
\hline \multirow{20}{*}{$\begin{array}{c}\text { \#2 Powerhouse, } \\
\text { Boiler \#3 }\end{array}$} & \multirow{6}{*}{ Coke Gas } & Coke Oven Gas Flow & $0-10$ MMCFD & 109 \\
\hline & & Coke Oven Gas Pressure & 0 - 15 PSIG & 110 \\
\hline & & Coke Oven Gas Temperature & 30 - 90 DEGF & 111 \\
\hline & & Coke Oven Gas Mass Flow & $0-20$ SCFM & 112 \\
\hline & & Radio & on/off & 123 \\
\hline & & Antenna & $\mathrm{n} / \mathrm{a}$ & $\mathrm{n} / \mathrm{a}$ \\
\hline & \multirow{6}{*}{ BF Gas } & Blast Furnace Gas Flow to boiler & $0-80$ MCFM & 113 \\
\hline & & Blast Furnace Gas Pressure & $0-50 " \mathrm{H} 2 \mathrm{O}$ & 114 \\
\hline & & Blast Furnace Gas Temperature & $30-150$ DEGF & 115 \\
\hline & & Blast Furnace Gas Mass Flow & $0-400$ SCFM & 116 \\
\hline & & Radio & on/off & 124 \\
\hline & & Antenna & $\mathrm{n} / \mathrm{a}$ & $\mathrm{n} / \mathrm{a}$ \\
\hline & \multirow{4}{*}{ Economizer } & Economizer Inlet Temperature & $200-300$ DEG F & 117 \\
\hline & & Economizer Outlet Temperature & $500-700$ DEG F & 118 \\
\hline & & Radio & on/off & 125 \\
\hline & & Antenna & $\mathrm{n} / \mathrm{a}$ & $\mathrm{n} / \mathrm{a}$ \\
\hline & \multirow{4}{*}{ Preheater } & Preheater Inlet Temperature & $30-200$ DEG F & 119 \\
\hline & & Preheater Outlet Temperature & $400-600$ DEG F & 120 \\
\hline & & Radio & on/off & 126 \\
\hline & & Antenna & $\mathrm{n} / \mathrm{a}$ & $\mathrm{n} / \mathrm{a}$ \\
\hline
\end{tabular}




\section{Installed Wireless Network}

As discussed in a previous section, the integration of the new wireless system with the existing E.T. Plant IT infrastructure is critical to project success. In the solicitation, it was expected that the installed system would make use of the existing Level 2 network for backhaul to the computer room in the Caster building. The architecture was approved by E.T. Plant IT prior to release of the solicitation.

The architecture proposed and awarded to Andrews did not use Level 2 for backhaul, instead relying on

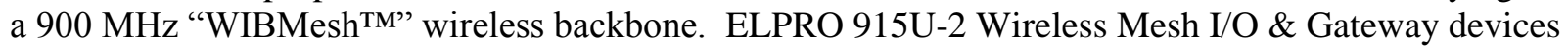
located at each operating facility provide the necessary communications bandwidth. These devices provide a low-impact, reliable backhaul infrastructure that was implemented successfully at the E.T. Plant (Fig. 22).

In the original architecture a firewall in the L1/L2 Bridge at each operating facility where a sensor network was installed and connected to the E.T. Plant, LAN would be required. In the as-built architecture, only one firewall is required, located in the Main Computer Room between the Data Acquisition Unit and the Server provided by the project. The firewall provided by Andrews is approved by the E.T. Plant IT group. The remaining condition of approval for installation by the IT group was that the IT group is responsible for installation and configuration of the actual connection to the U.S. Steel network. An excerpt from the drawing showing where the interconnection occurs and indicating U.S. Steel's Level 2 responsibility is shown in Fig. 23. 


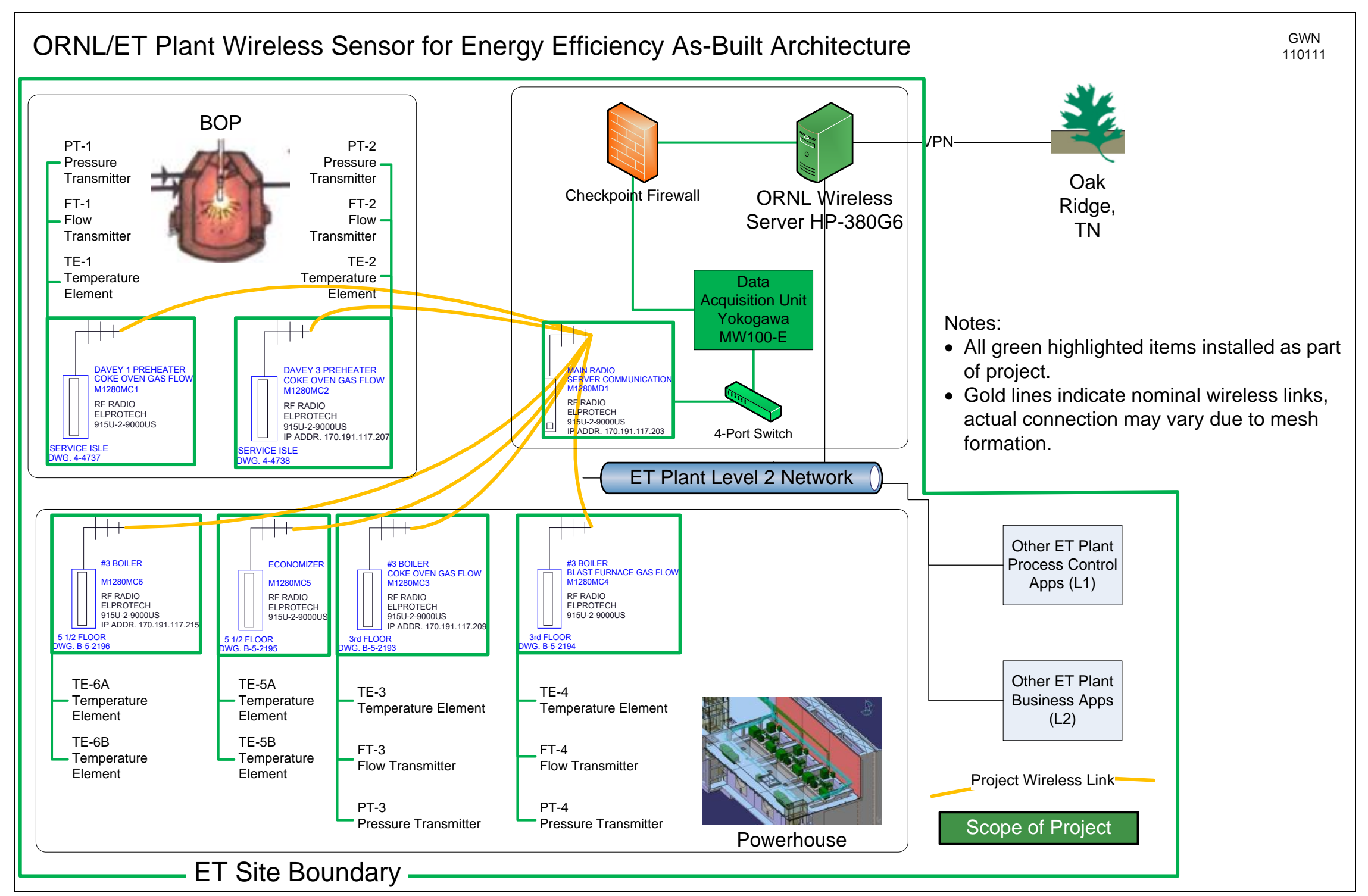

Fig. 22. Installed network architecture and IT integration for wireless monitoring system at E.T. Plant. 


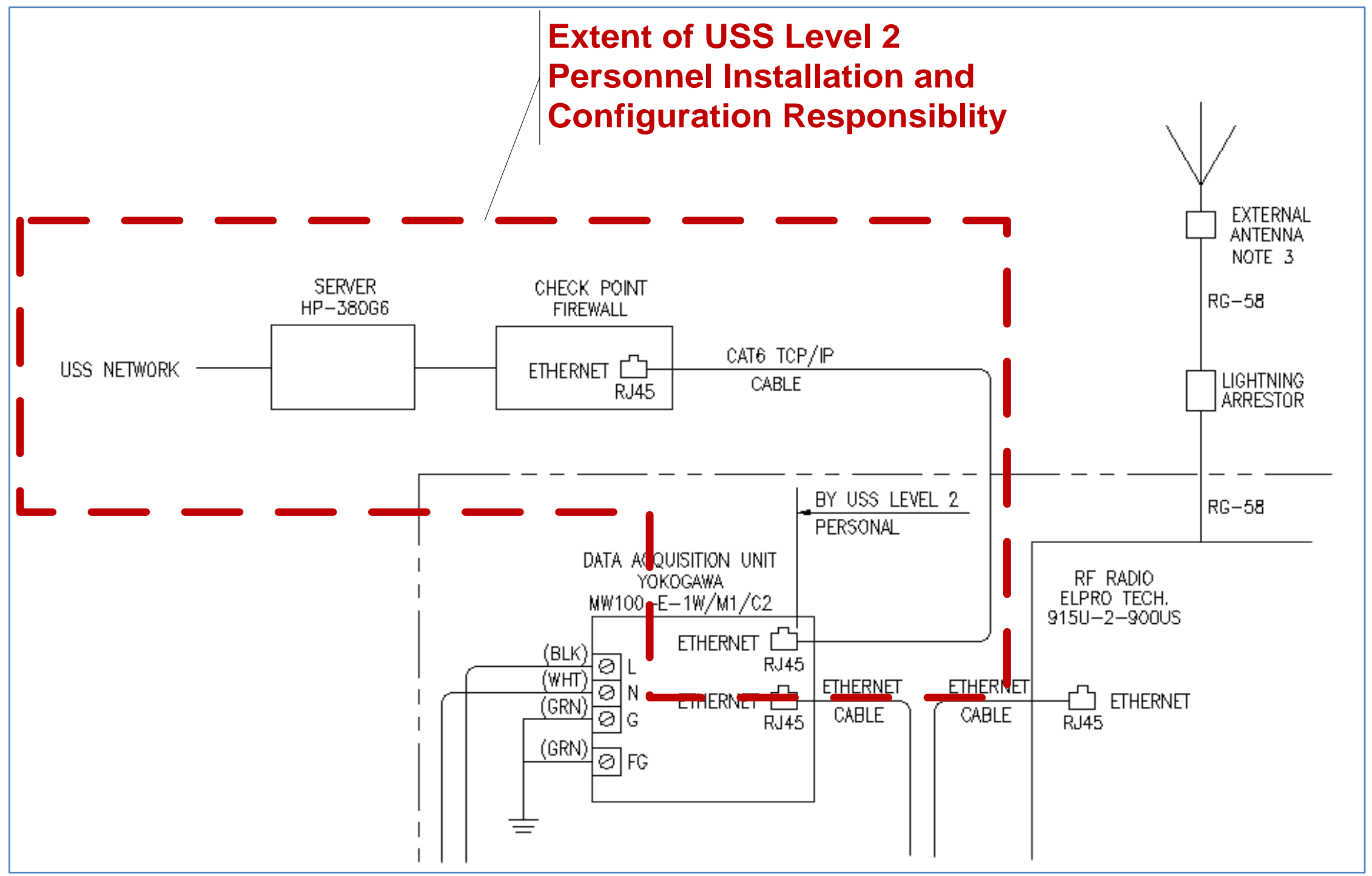

Fig. 23. Excerpt of Andrews' drawing of main radio unit showing extent of U.S. Steel personnel installation and configuration responsibility. 
Per the solicitation, the installed system would be considered successfully commissioned only after operating for eight continuous hours at full capability, with all displays operational and at design data transfer rates with no faults. Beginning the evening of November 8, 2010, radios and sensors installed by Andrews ran continuously without interruption for eight hours. Representatives from ORNL were on-site on November 9, 2010, and observed the real-time data collected by the sensors via the GUI software provided by Andrews. Representatives from Andrews demonstrated the variety of displays, reports, and data fields available to end-users. The ORNL team received some initial training on the data acquisition software used by Andrews but confirmed the expectation that more involved training would be necessary at a later date.

With all installed systems and equipment working properly, ORNL representatives accepted responsibility for the commissioned system ahead of schedule. This event initiated the operations test, which was ongoing for the duration of the project.

Following the acceptance test, ORNL staff evaluated data collected over an 18-hour period. For each subsystem, the process measurements and calculation were plotted in a graph. The graphs, coupled with excerpts from Fig. 21 and Table 4 applicable to a process, provide the components necessary to develop an understanding of the focus of the project.

Fig. 24 and Fig. 25 show initial measurements in two of the preheaters in the BOP. Fig. 26 and Fig. 27 show similar measurements taken in the Boilers at the Powerhouse, and Fig. 28 shows the measurements from the economizer and preheater in the Powerhouse. These initial measurements form the basis of the benchmarking done to quantify improvements enabled by the wireless sensor network. 


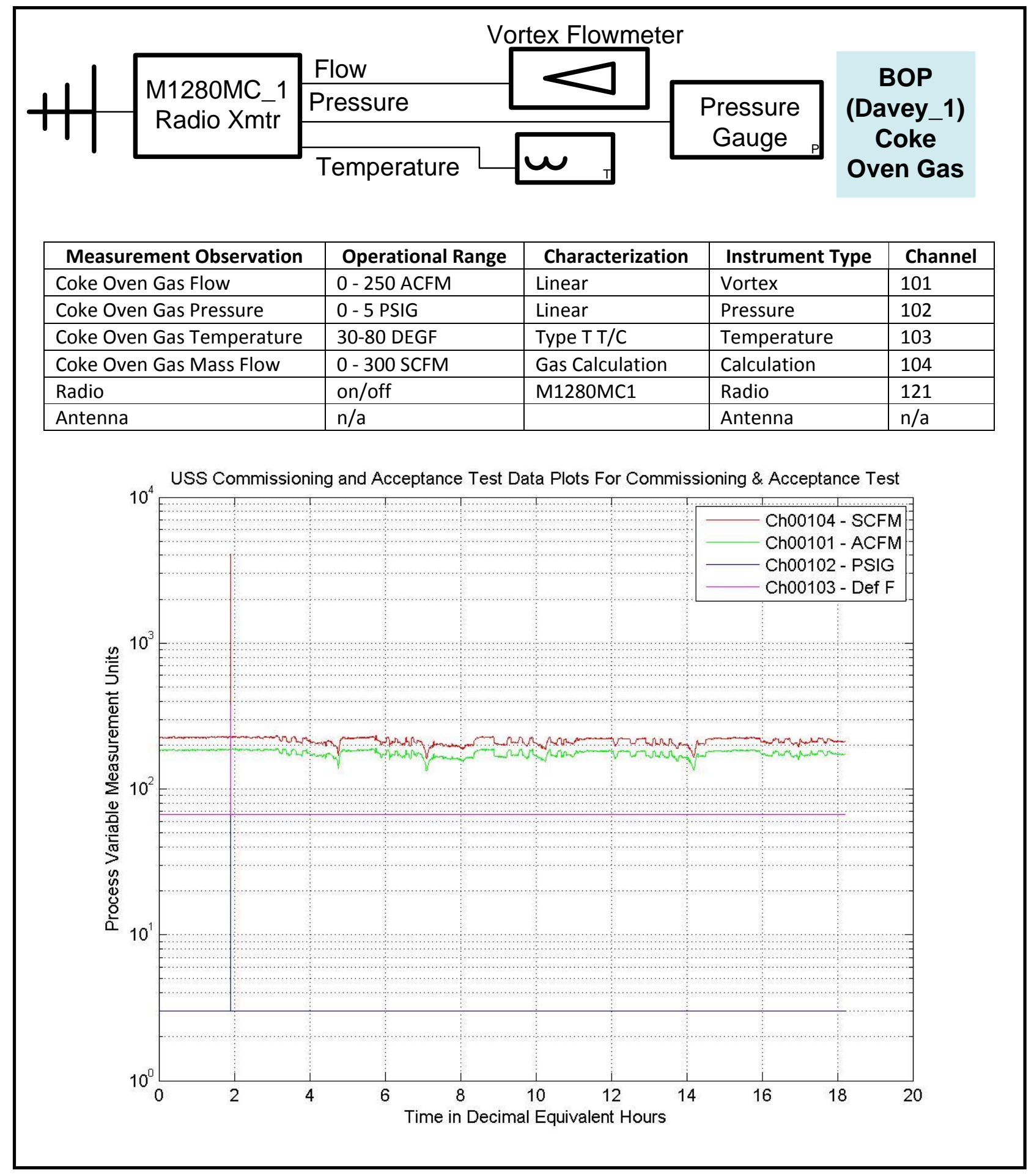

Fig. 24. Initial measurements of sensors in Davey 1 preheater in BOP. 


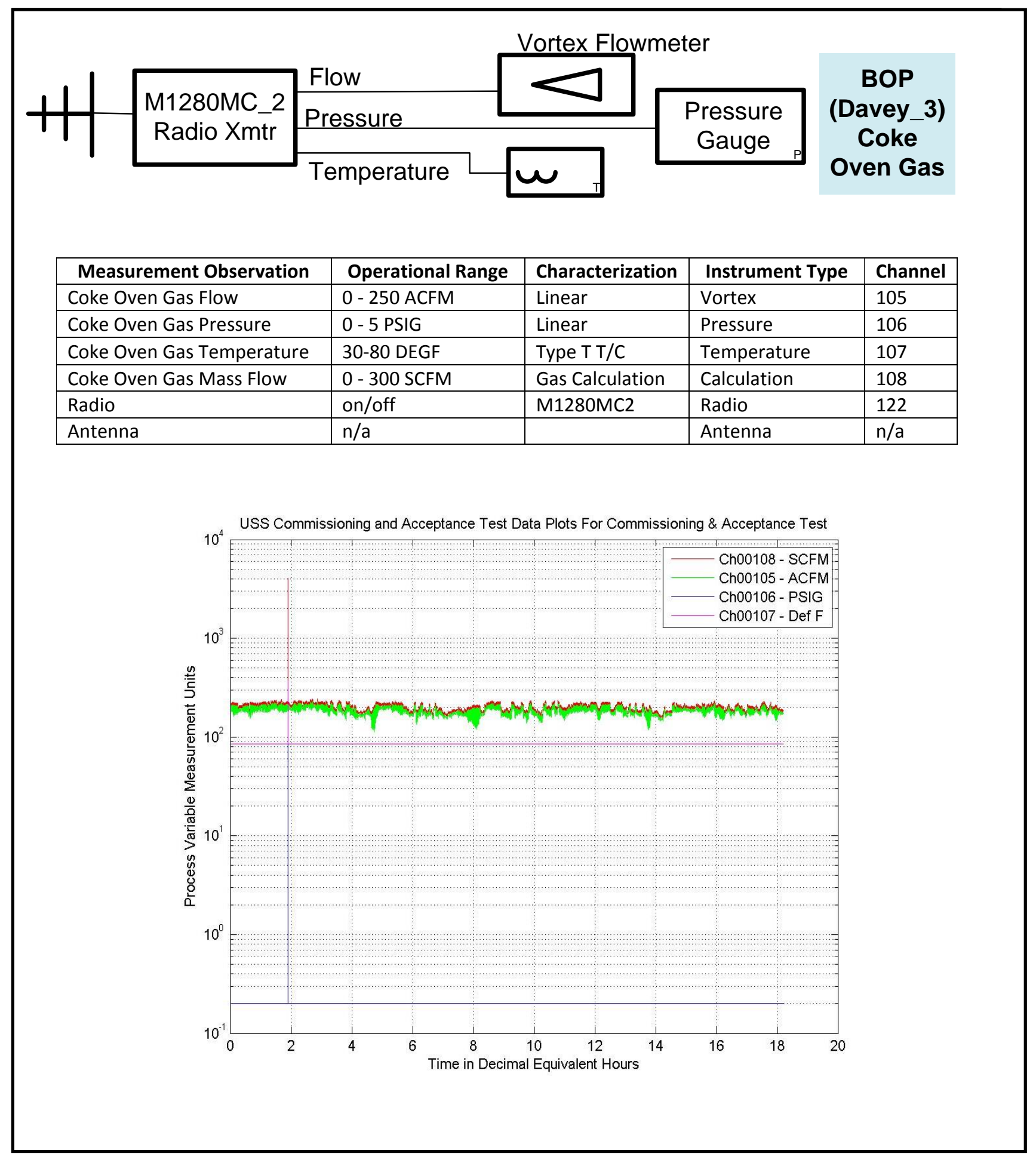

Fig. 25. Initial measurements of sensors in Davey 3 preheater in BOP. 


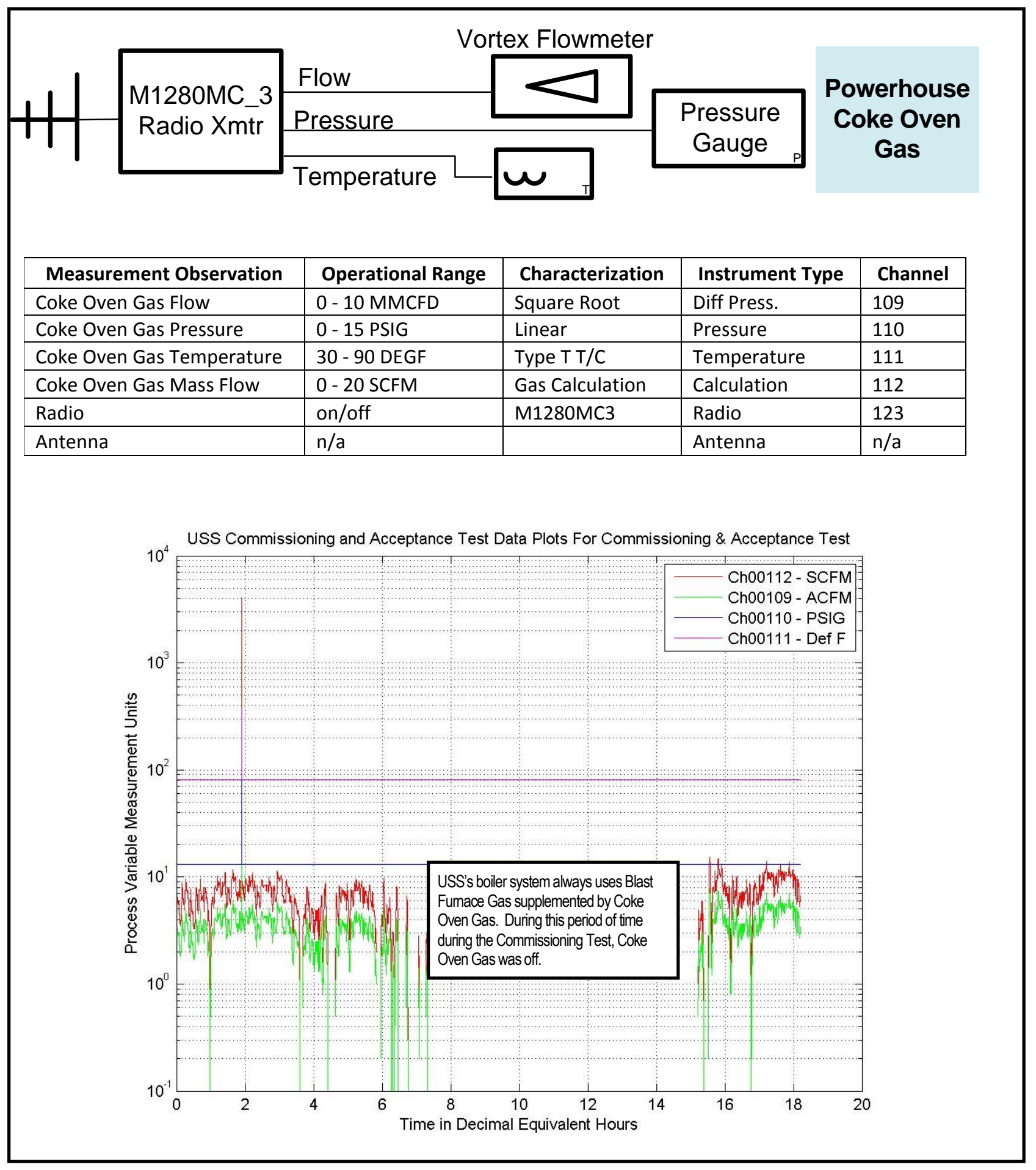

Fig. 26. Initial measurements of coke oven gas sensors in Boiler \#3 in \#2 Powerhouse. 


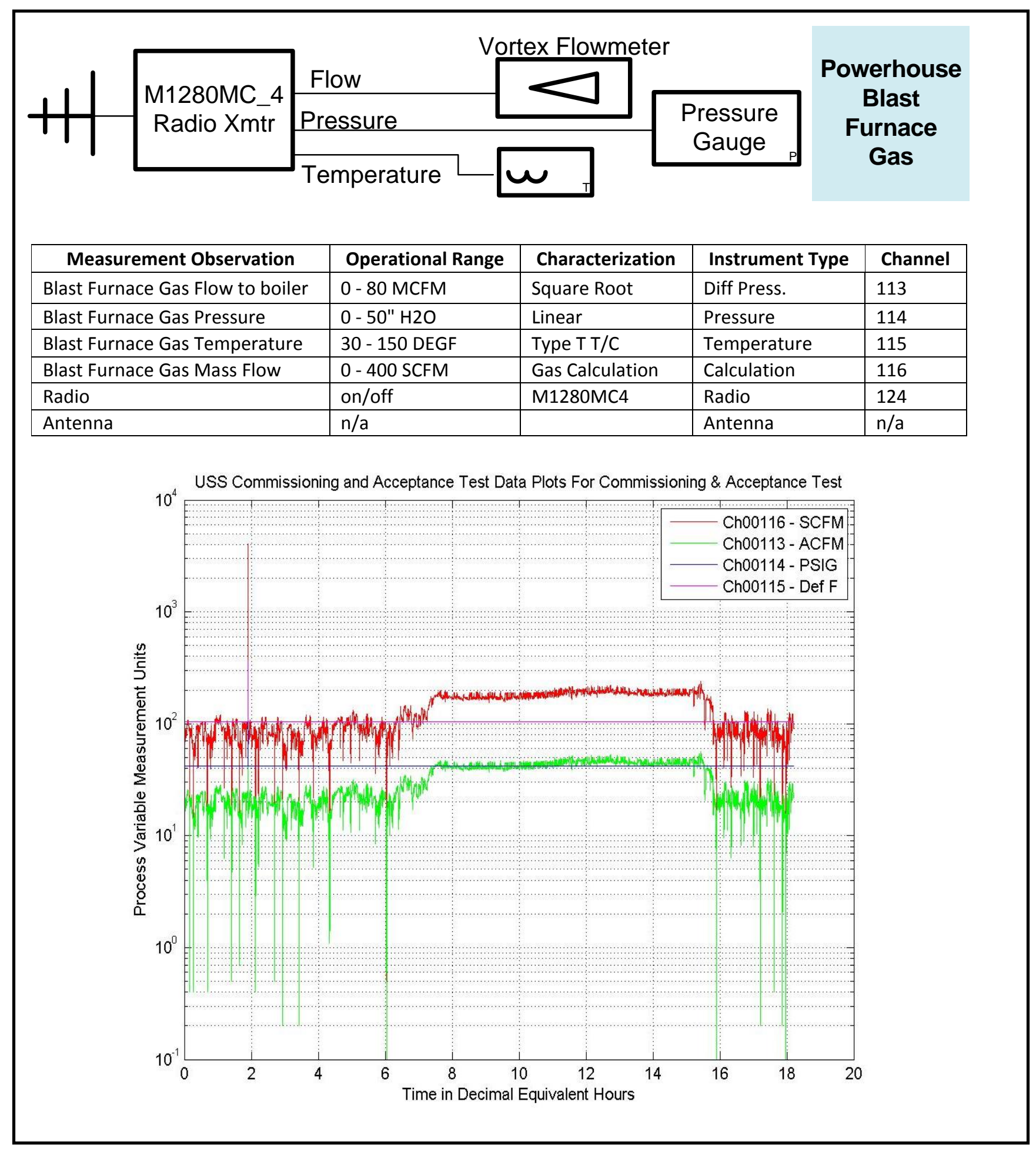

Fig. 27. Initial measurements of blast furnace gas sensors in Boiler \#3 in \#2 Powerhouse. 


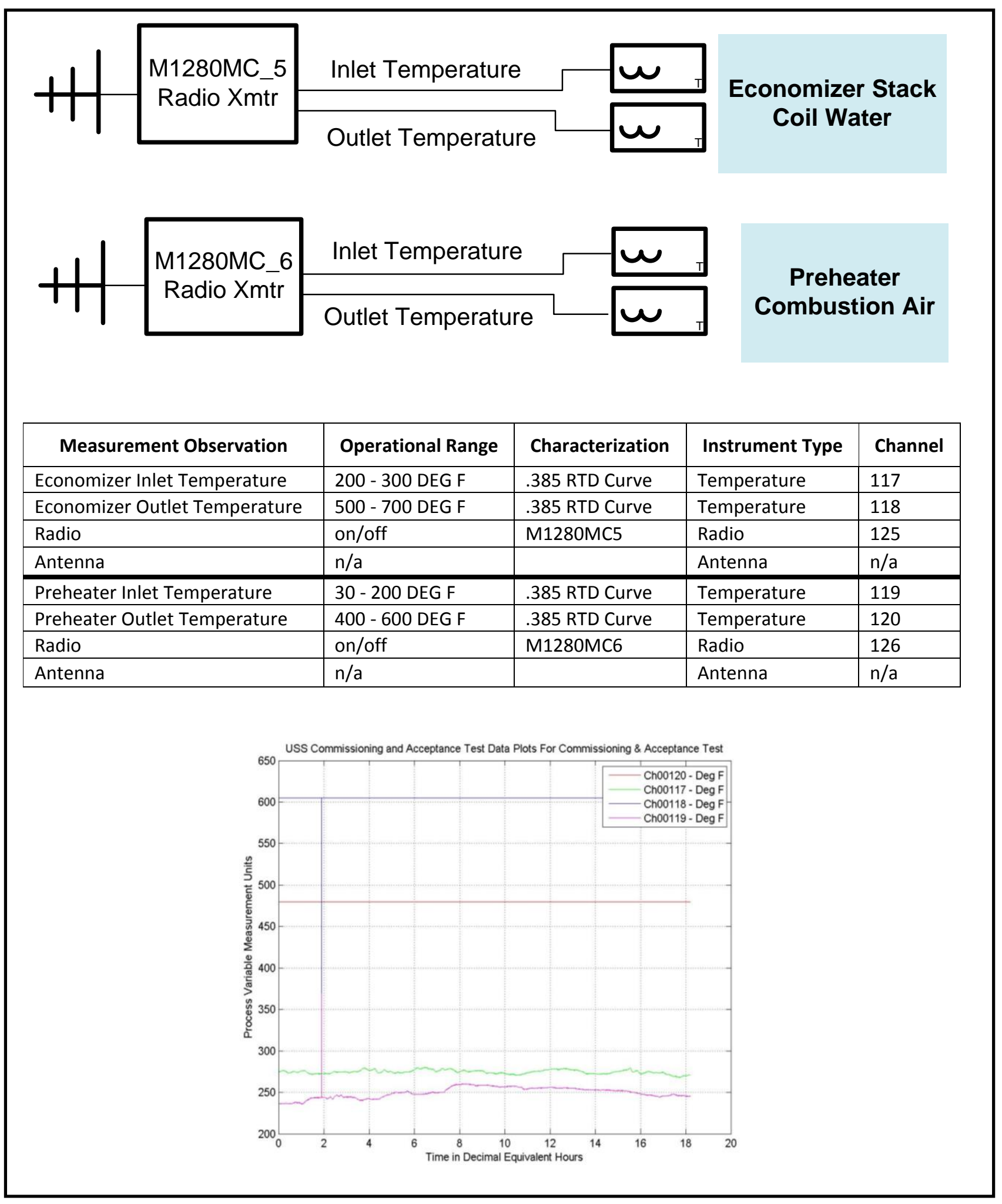

Fig. 28. Initial measurements of economizer and preheater temperature sensors in Boiler \#3 in \#2 Powerhouse. 


\section{Benefits Assessment}

Based on the multitude of monitoring opportunities prioritized by U.S. Steel and the funding provided by DOE, the wireless system implemented by Andrews at the E.T. Plant provides a solid combination of priorities, processes, and entities as well as a foundation on which to expand the wireless network of sensors.

Over the year and nine month span of the operational testing phase of the project, the data collected by the system provided valuable information. Operators who manage energy use at the E.T. Plant on a daily basis analyzed the data in order to change processes, maintain or change equipment, or take other actions. Based on the benefits realized from the observation of the installed wireless sensors, U.S. Steel representatives may consider increasing the number of measurements and grow the system.

Working with historical information provided by U.S. Steel for energy usage, product yields, operating parameters, inventory and more, ORNL compared data with the same characteristics over several months. This report showcases differences between baseline system operations and the system inclusive of the wireless monitoring system to DOE and other interested parties. As a result of this analysis, ORNL met the ultimate goal of this project, which was to realize energy savings as a result of the installation of a wireless sensor network at the E.T. Plant.

Project successes:

- Deployment of the U.S. Steel wireless energy monitoring system.

- Completion of the U.S. Steel Commissioning and Acceptance Test at the E.T. Plant on November 9, 2010. The test was conducted over an 8-hour period with all (16 sensors) reporting.

- Operation of the U.S. Steel wireless energy monitoring system since November 2010 without any [unexpected] system down times. This equated to an availability of greater than $98 \%(95 \%$ reliability). All down times were documented and identified as expected predictive maintenance routines and known operational shut downs. This was a major achievement since technology adopters risk not only loss of monetary investments but also operational and business losses resulting from adopting systems and changing business profiles only to find out that the system is failing at a rate that threatens economic viability.

- 'NO' security breaches or mismanagement of information. This was supported by audits conducted by U.S. Steel's operational personnel responsible for IT concerns.

The success of the project can be attributed to the following activities:

- The use of the Enterprise Derivative model to quantify value proposition of proposed wireless sensors and actuators in terms of the 'energy savings' [hypothesis] inheritance at the E.T. Plant

- Leveraging technology innovations that came out of the DOE/ORNL wireless technologies in harsh environments Program

- Establishing system figures of merit that included reliability, availability, quality of service as part of the project descriptors and analysis to enhance overall system acceptance (reduce threats)

- Leveraging ORNL's extensive wireless experience and analytic capabilities extending from their work in harsh environments

- Extensive use of standards and protocols

- Leveraging the military and private industry experience of ORNL project team members

- Application of analysis procedures and protocols for conducting system design and operational figures of merit 
The experience gained in this project identified areas and protocols where wireless technology can improve operational efficiency and reduce energy usage in steelmaking. These findings, in turn, can be extended to other energy intensive industries. 


\section{Commercialization}

Both Andrews in the integrated mill market and Wunderlich-Malec in the EAF market have agreed that this project will inspire further deployments of their wireless offerings among their customers. ORNL's work with these vendors provided them with the guidance and technical underpinnings that they needed to confidently deploy their systems.

This demonstration of the first commercial installation of wireless in harsh environments has shown the viability of the technology and the documented significant energy savings. Both U.S. Steel and CMC intend to expand their installations and harness even more of the energy savings available. The supplying vendors now have demonstrated their abilities and are showcasing their new success at technical venues around the world. 


\section{Conclusions}

The deployment for this wireless steel demonstration project was to illustrate that wireless had "come of age" and was "ready for prime time" deployment as a critical enabler for energy efficiency in harsh environments. All stakeholders are convinced that this goal was exceeded and will represent the first steps toward wide-scale deployment in this market.

The wireless networks in both installations showed extended, documented availability figures suitable for use in production environments (greater than 95\%). The data provided by the system have allowed CMC to consider new options in achieving increased efficiency at their site through improved charge carbon measurements. These process improvements will be through reduced electrical and charge carbon consumption. As a result of the new wireless process data, CMC is preparing a design, budget, and capital request for a new system for weighing charge carbon.

The wireless sensor systems installed at both the U.S. Steel and CMC sites achieved levels of availability expected for production use, greater than $95 \%$ data availability. The data provided by the systems have allowed each company to consider new options in achieving improved efficiency at their site. The CMC site has taken aggressive action and has subsequently realized significant energy savings greater than 50\% in one subsystem, projected to provide an ROI payback in less than a year. The EDA clearly indicated where the "sweet spots" were and guided the users in their decisions to proceed. Both end users have agreed that further deployments of wireless technology would be forthcoming with subsequent continued improvements in energy efficiency.

Both sites had previously experienced unsuccessful deployments of wireless technology in their facilities but were cooperative to support a new strategy. The deployment for this wireless steel demonstration project illustrated that wireless had "come of age" and was "ready for prime time" deployment as a critical enabler for energy efficiency in harsh environments. U.S. Steel saw the availability figures as suitable for their future plans to improve energy efficiency at their site while CMC chose to make their first adjustments during the team's test period and their results showed over 50\% reduction in natural gas consumption. Both companies expect to continue to make adjustments over the next year to improve their energy efficiency and to deploy additional wireless sensors to look for new opportunities that can be enabled through the wireless sensor network.

There were no major issues with the installation of the wireless energy monitoring systems. The contractors performed the installation during normal maintenance days in the meltshop. The integration of the energy monitoring server into the network was straight forward in both installations. The data received from the wireless instruments are now available through the control Ethernet to other control and monitoring systems for maintenance and engineering purposes.

The only experienced and/or anticipated maintenance issue (other than some that were self-induced) is the eventual replacement of the batteries in the transmitters. At the present 16 -second update rate, the batteries are expected to last approximately 3 years. All of the wireless transmitters have had no problems. The configuration and setup of the wireless devices is relatively simple, and once the devices are added to the wireless network, any additional configuration can be done through a web-based interface remotely. From CMC's standpoint, the wireless network is surprisingly robust and the physical coverage of the operations is impressive. The self-organizing behavior of the network allows the system to cover a big footprint and still provides sufficient connectivity for many devices. CMC has already added several instruments to the network since the cost barrier is relatively low for adding more wireless devices and the procedure is simple. 
Important lessons learned (or at least relearned) from these installations include the following:

1) Diversity is needed in these harsh environments to achieve the levels of reliability and resiliency required;

2) Retries can be fatal. A plan is needed to get the data through the first time;

3) Industrial processes are inherently deterministic. Leveraging that determinism can help improve the wireless system performance.

The team's radio frequency (RF) site survey at the $\mathrm{CMC}$ site (see Appendix) revealed that a critical interferer rose from below the noise level to greater than $-20 \mathrm{~dB}$, periodically. Any attempt at trying to send our wireless signal through this interferer would be fruitless. Clearly our team needed to use temporal diversity along with the spatial (mesh) diversity and the frequency (channel-hopping) diversity approaches inherent in the protocol. By timing the transmissions to occur during the intermittent quiet times, our team could ensure that information arrived at its destination reliably and without the waterfall of retries that might occur if and when transmissions were simply sent at random intervals. By taking advantage of the process determinism, our team was able to achieve the $98 \%$ availability required by the user. The WirelessHART® protocol was easily adapted to respond to this surprising anomaly. Another protocol, based in the ANSI-standard ISA100.11a, may have been able to respond automatically under these conditions and find a timing solution without manual intervention.

The CMC site had previously experienced unsuccessful deployments of wireless technology in their facilities, largely due to the "canyons of metal" illustrated in Fig. 29, but was cooperative to support a new strategy. The deployment for this wireless steel demonstration project illustrated that wireless had "come of age" and was "ready for prime time" deployment as a critical enabler for energy efficiency in harsh environments. CMC Steel expects to continue to make adjustments over the next year to improve their energy efficiency and to deploy additional wireless sensors to look for new opportunities that can be enabled through the wireless sensor network.

The results from this demonstration activity will be publicized through numerous venues in an attempt to reach related industries and inspire them to consider wireless sensor networks for enabling energy efficiency gains at their sites.

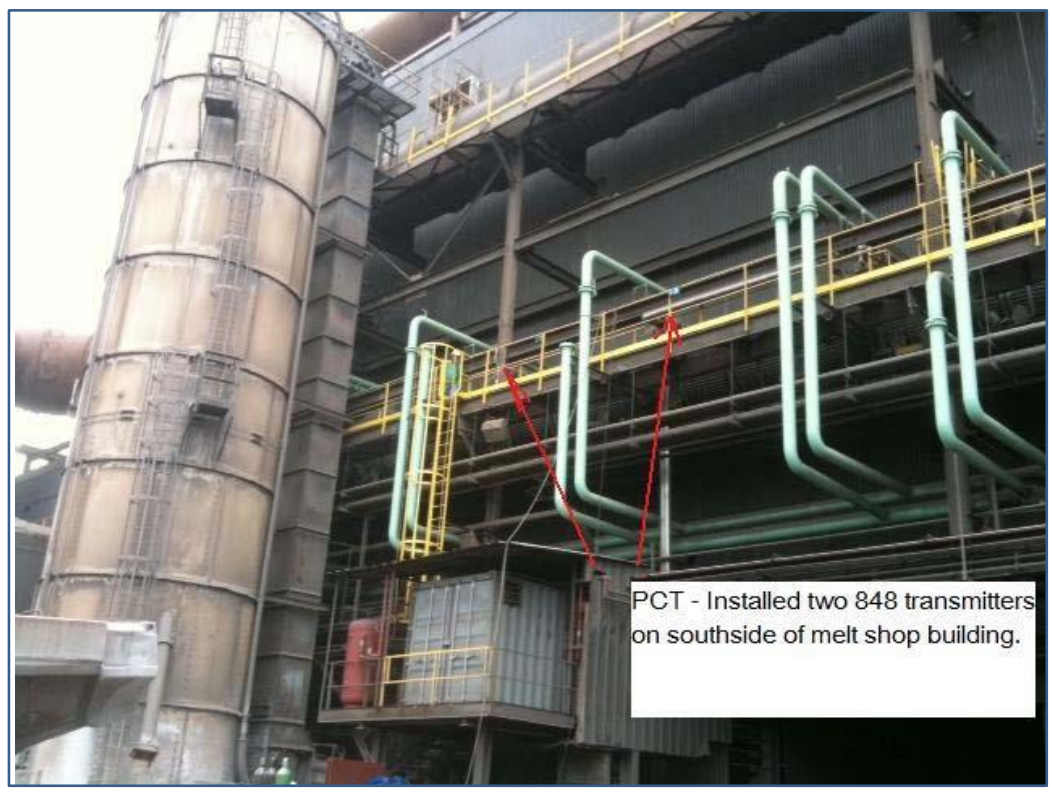


Fig. 29. The "canyons of metal" environment typical to steel-making facilities - a wireless challenge.

Experience in facilities such as these has shown that there are lots of ways to do wireless badly. A successful deployment hinges on combining the expertise of a critical team of players from the end-user, vendor, and an experienced wireless expert. Successfully deploying industrial wireless sensor networks requires a team with members knowledgeable in:

1) Wireless - RF issues, antenna configurations, shielding, electromagnetic interference.

2) Industrial - harsh environment issues associated with temperature, vibration, maintenance, training, operations

3) Sensor - calibration, sampling, analog-to-digital conversion, variability

4) Networks - security, commissioning, addressing, troubleshooting, latency, throughput, reliability

This installation was a major success because of the team effort to identify the problem to be solved (energy efficiency), targeting the solution space (e.g., EAF), developing the acceptance criteria, executing and testing the installation over an extended period of time. End user utilization is the final success criteria. Because of the harsh environment typical in these steel-making facilities, the cost for sensors continues to be relatively high (about $\$ 4-5 \mathrm{~K}$ per sensor). Less restrictive environments, sometimes referred to as Machine-to-machine (M2M) installations, are beginning to see wireless sensor networks with around $\$ 200$ per node as a reasonable deployed cost. In any case, the avoidance of the wiring costs (typically $\$ 200$ per foot in a steel mill) can be avoided so the potential deployment is still economically viable in most industrial facilities. The nuclear power industry has become an "early adopter" for wireless sensor networks since their wiring costs can run as high as $\$ 4,000$ per foot. More information is available from the Electric Power Research Institute (EPRI) where their report on the Comanche Peak Nuclear Power Plant wireless sensor network installation showcases a large-scale demonstration deployment there.

The results from this demonstration activity will be publicized through numerous venues in an attempt to reach related industries and inspire them to consider wireless sensor networks for enabling energy efficiency gains at their sites. 


\section{Bibliography}

\section{Publication List, Brief (more comprehensive list available upon request)}

1. Wayne Manges, John N. Sorge, Cyrus W. Taft, "Industrial Wireless Sensors: A User's Perspective on the Impact of Standards on Wide-Spread Deployment, Proceedings of 55th Annual ISA POWID Symposium, 2012.

2. John N. Sorge, Cyrus W. Taft, and Wayne W. Manges, Proceedings, 2011 Future of Instrumentation International Workshop (FIIW) "Industrial Wireless Sensor Standards; A User Perspective," Oak Ridge, Tennessee, November 2011.

3. Wayne W. Manges, Proceedings, TCIPG Summer School: Cyber Security for Smart Energy Systems, "Wireless Communication Technologies in Electric Energy Systems," St. Charles, Illinois, June 2011.

4. Peter Fuhr, Wi-Fi Sensors; Wayne Manges, Oak Ridge National Labs; Patrick Schweitzer, ExxonMobil Research \& Engineering, "Wireless Technologies-Implications for Power Systems," 53 ${ }^{\text {rd }}$ ISA POWID Symposium 2010, June 9, 2010.

5. Wayne W. Manges, "Wireless Control - Has the Time Finally Arrived," proceedings of the Industrial Wireless \& Ethernet Conference - IDC Technologies, Manchester, United Kingdom, December 2-3, 2009.

6. Wayne W. Manges, "ISA100 - THE Standard for Wireless Systems for Industrial Automation," proceedings of the Industrial Wireless \& Ethernet Conference - IDC Technologies, Manchester, United Kingdom, December 2-3, 2009.

7. Elliott Levine, Peter Fuhr, Teja Kuruganti, Brian Kaldenbach, Wayne Manges, and Andrew Loebl, "U.S. Department of Energy's Wireless Energy Efficiency Initiative," American Council for an Energy-Efficient Economy (ACEEE), July 2009.

8. Peter Fuhr and Wayne Manges, "Wireless and the Smart Grid," ISA InTech, April 2009.

9. Teja Kuruganti, Walter Dykas, Wayne Manges, Tom Flowers, Mark Hadley, Paul Ewing, and Thomas King, "Wireless System Considerations When Implementing NERC Critical Infrastructure Protection Standards," February 25, 2009.

10. Richard C. Ward, Glenn O. Allgood, John R. Knox, "The Enterprise Derivative Application: Flexible Software for Optimizing Manufacturing Processes”, ORNL/TM-2008/107, November 11, 2008.

11. Wayne W. Manges, "Performance Metrics for Wireless Distributed Control Systems and Other News," Sensors: The Journal of Applied Sensing Technology, November 29, 2006.

12. Wayne W. Manges, “An Inadvertent Barrier to Entry?" Sensors: The Journal of Applied Sensing Technology, November 6, 2006.

13. Wayne W. Manges, "SP100's Meeting at ISA Expo, Government Funding, and Barriers to Entry," Sensors: The Journal of Applied Sensing Technology, October 31, 2006.

14. Peter Fuhr, Hesh Kagan, Rob Conant, Jose A. Gutierrez, and Wayne Manges, "Wireless Signal Congestion: Whatever Happened to Peaceful Coexistence?" Sensors: The Journal of Applied Sensing Technology, October 2006, p 18.

15. Wayne W. Manges, “The Fragility Factor?” Sensors: The Journal of Applied Sensing Technology, October 6, 2006.

16. Wayne W. Manges, "SP100's Proposal Conference, Going "Green" with Wireless, and Fragility" Sensors: The Journal of Applied Sensing Technology, October 2, 2006.

17. Phani Teja Kuruganti and Wayne W. Manges, "Wireless standard crucial in a networking world," ISA InTech, October 2006, p 72.

18. Wayne W. Manges, “A Little Help Here!” Sensors: The Journal of Applied Sensing Technology, September 5, 2006. 
19. Wayne W. Manges, "SP100's Proposal Conference, Wireless in Underwater Environments, and Modeling and Simulation" Sensors: The Journal of Applied Sensing Technology, September 1, 2006.

20. Wayne W. Manges, "The Trouble with Creating Standards," Sensors: The Journal of Applied Sensing Technology, August 7, 2006.

21. Wayne W. Manges, "SP100 Proposals and Requirements, and a "WOW" Conference!" Sensors: The Journal of Applied Sensing Technology, September 2, 2006.

22. Ivan Howitt, Wayne W. Manges, Phani Teja Kuruganti, Glenn Allgood, José A. Gutierrez, and James M. Conrad, "Wireless industrial sensor networks: Framework for QoS assessment and QoS management," ISA Transactions ${ }^{\circledR}$, Vol. 45, No. 3, July 2006, pp 347-359.

23. Wayne W. Manges, "Government-Funded R\&D, Sensors Expo, and Wireless Standards" Sensors: The Journal of Applied Sensing Technology, June 27, 2006.

24. Wayne W. Manges, "The Future of Power Harvesting," Sensors: The Journal of Applied Sensing Technology, June 13, 2006.

25. Wayne W. Manges, "SP100's Pace, Perceptions of Wireless, and Power Harvesting" Sensors: The Journal of Applied Sensing Technology, May 24, 2006.

26. Wayne W. Manges, "In Search of Ubiquity," Sensors: The Journal of Applied Sensing Technology, April 26, 2006.

27. Wayne W. Manges, "Wireless Sensing Ubiquity, Government Funding, and SP100 News," Sensors: The Journal of Applied Sensing Technology, April 25, 2006.

28. Wayne W. Manges, "The Integration Imperative for Wireless," Sensors: The Journal of Applied Sensing Technology, April 14, 2006.

29. Wayne W. Manges, "The Integration Imperative," Sensors: The Journal of Applied Sensing Technology, April 5, 2006.

30. Wayne W. Manges, "\$7 Billion, Phases of Visibility, and Other Developments," Sensors: The Journal of Applied Sensing Technology, February 1, 2006.

31. Phani Teja Kuruganti and Wayne W. Manges, "Interoperability among Standards for Industrial Wireless Automation," 2006.

32. James E. Hardy, Wayne W. Manges, Oak Ridge National Laboratory; Jose A. Gutierrez, Eaton Corporation; and Phani Teja V. Kuruganti, University of Tennessee, "Wireless Sensors and Networks for Advanced Energy Management," Proceedings of the ACEEE American Council for an Energy-Efficient Economy Summer Study on Energy Efficiency in Industry, West Point, New York, July 19, 2005.

33. Wayne W. Manges, Phani Teja V. Kuruganti, and Stephen F. Smith, Oak Ridge National Laboratory, "The Extreme Measurement Communications Center: Supporting Wireless Communications for Harsh Environments," Proceedings of the International Workshop on Wireless and Industrial Automation (WIA'05), San Francisco, California, March 7, 2005.

34. Wayne W. Manges, "Inflation is Our Friend," ISA InTech, July 2005, p 92.

35. Peter L. Fuhr and Wayne Manges, "Why Wireless?” Wireless for Industry, Supplement to Sensors Magazine, Summer 2004.

36. Manges, W. W. and G. Allgood, "Intelligent Wireless Technology: Past, Present and Future;" Gate-M Interagency Program Review, NIST, Gathersburg, MD USA, June 25, 2003.

37. Manges, W.W. and G. Allgood, "Intelligent Wireless Technology: Past, Present, and Future Small Lot Intelligent Manufacturing," NIST Small Lot Manufacturing Conference, Gaithersburg, MD USA, NIST, September 2, 2003.

38. W. W. Manges, Michael R. Moore, Stephen F. Smith, Glenn O. Allgood, Michael S. Emery, Roberto Lenarduzzi, Mark A. Buckner, Timothy J. McIntyre, Richard L. Crutcher, and Michael S. Hileman, "OIT Wireless Telemetry for Industrial Applications," ORNL/TM-2002/173, August 19, 2002, available at www.osti.gov/bridge. 
39. W. W. Manges, G. O. Allgood, "Wireless Sensor Network Security," Sensors: The Journal of Applied Sensing Technology, April 2002, Vol. 19 No. 4.

40. Wayne W. Manges and Glenn O. Allgood, "How Secure is Secure?" Sensors: The Journal of Applied Sensing Technology, February 2002, Vol. 19 No. 2, pp 14-23.

41. Glenn O. Allgood and Wayne W. Manges, "A Perspective on Data Analysis," Sensors: The Journal of Applied Sensing Technology, December 2001, Vol. 18 No. 12, pp 18-24.

42. Glenn O. Allgood and Wayne W. Manges, "Sensor Agents - When Engineering Emulates Human Behavior," Sensors: The Journal of Applied Sensing Technology, August 2001, Vol. 18, No. 8, pp 28-39.

43. Wayne W. Manges, Glenn O. Allgood, William B. Dress, Jr., Timothy D. Vane, and James Lee, "Wireless Sensors - Buyer Beware," Sensors: The Journal of Applied Sensing Technology, April 2001, Vol. 18, No. 4.

44. Wayne W. Manges, "What now?" Sensors: The Journal of Applied Sensor Technology, February 2001, Vol. 18, No. 2.

45. Wayne W. Manges, Glenn O. Allgood, William B. Dress, Jr., Timothy D. Vane, and James Lee, "Measuring Inclination for Instrumented Parachute Drops - A WORK IN PROGRESS, Sensors: The Journal of Applied Sensor Technology, Motion Control, September 2000, Vol. 17 No 9. pp 101-105.

46. Wayne W. Manges, "Wireless Sensor Network Topologies," Sensors: The Journal of Applied Sensing Technology, May 2000, Vol. 17, No. 5, pp 72-77.

47. Wayne W. Manges, Glenn O. Allgood, Stephen F. Smith, Timothy J. McIntyre, Michael R. Moore, and Eric Lightner, "Intelligent Wireless Sensors for Industrial Manufacturing," Sensors: The Journal of Applied Sensing Technology, April 2000, Vol. 17, No. 4, pp 44-55

48. Wayne W. Manges, Glenn O. Allgood, and Stephen F. Smith, "It's Time for Sensors to Go Wireless, Part 2: Take a Good Technology and Make It an Economic Success," Sensors: The Journal of Applied Sensing Technology, May 1999, Vol. 16, No. 5, pp 70-80.

49. W. W. Manges, G. O. Allgood, S. F. Smith, "It's Time for Sensors to Go Wireless; Part 1: Technological Underpinnings," Sensors: The Journal of Applied Sensing Technology, April 1999, Vol. 16, No. 4, pp 10-20.

50. Wayne Manges and Glenn Allgood, “An Emerging Technology,” MRO Marketplace, November 1998, pp 7-11, Putnam Publishing Company, Itasca, IL.

51. W. W. Manges, "Wireless is Now! . Why Can't They See It?" Wireless For the Corporate User, June 1997, Wireless Publishing Company, Cedar Knolls, NJ.

52. Ayman A. Shourbaji, Wayne W. Manges, "How the Coming Wireless Revolution Will Impact Manufacturing,” Industrial Automation Show \& Conference, Chicago, March 1996. 


\title{
Appendices
}

Appendix A - USS RF Site Survey

\section{U.S. Steel RF Site Survey (July 2010) USS RF Site Survey Conducted on July 28-29, 2010}

\author{
Teja Kuruganti \\ Kenneth Woodworth
}

\section{PURPOSE/OBJECTIVES}

The purpose of this radio frequency $(R F)$ survey is to empirically analyze the RF environment in the US Steel ET Plant, Braddock, PA. Three different frequency bands are chosen mainly are 902-928MHz, $2.4-2.4835 \mathrm{GHz}$ and $5.725-5.875 \mathrm{GHz}$. These frequency bands correspond to the unlicensed Industrial, Scientific and Medical (ISM) bands, commonly used in current wireless networking technologies. The collected data will help understand the background interference and noise levels before the deployment of the desired wireless network and also help predict signal strength and related propagation issues.

\section{APPROACH}

All of the measurement equipment is characterized extensively for any spurious EM emissions. The measurement equipment that will be used for this test includes:

1. Rhode \& Schwarz FSH3 spectrum analyzer.

2. Electro-Metrics EM-6105 wideband discone antenna.

3. 2.4GHz \& 5.8GHz Transceivers with omni-directional antennae

4. Wide-band discone antenna

5. 2.4GHz wireless transceivers.

6. Laptop computer

The purpose of this test is to scan for frequencies in the environment and related power levels residing in and around the Steel Mill to identify potential interference and noise sources. This survey is performed in accordance with IEEE 473 standard. The complete measurement takes $18 \mathrm{~min}$. including saving of the data per each run. The test will be repeated at multiple locations identified as potential points of interest with respect to processes of interest during this deployment.

\section{TEST SETUP}

The Rhode \& Schwartz FSH3 spectrum analyzer is controlled by a laptop running LabView software. A customized script was used to scan the spectrum in five different bands for a total of $3 \mathrm{~min}$ per band. The bands are $150 \mathrm{KHz}$ to $30 \mathrm{MHz}, 30 \mathrm{MHz}$ to $500 \mathrm{MHz}, 500 \mathrm{MHz}$ to $1 \mathrm{GHz}$, $1 \mathrm{GHz}$ to $2 \mathrm{GHz}$, and $2 \mathrm{GHz}$ to $3 \mathrm{GHz}$. This results in a complete scan from $150 \mathrm{KHz}$ to $3 \mathrm{GHz}$ over a 15-min scan window. The laptop records the frequency and power level at designated increments and records the maximum signal presented during the 3-min scan. 
Simultaneously, 2.4GHz and $5.8 \mathrm{GHz}$ access points are used to scan the respective bands for possible $802.11 x$ sources.

\section{CONCLUSION}

- The 2.4GHz band has an average noise floor of $-70 \mathrm{dBm}$.

- Limited areas have $2.4 \mathrm{GHz} 802.11 x$ networks (see plots for more details)

- The $5.8 \mathrm{GHz}$ band is relatively clean with average noise floor of $-75 \mathrm{dBm}$

- $\quad$ The plots below provide the RF environment in detail

\section{Location 1: $3^{\text {rd }}$ floor of Power House}

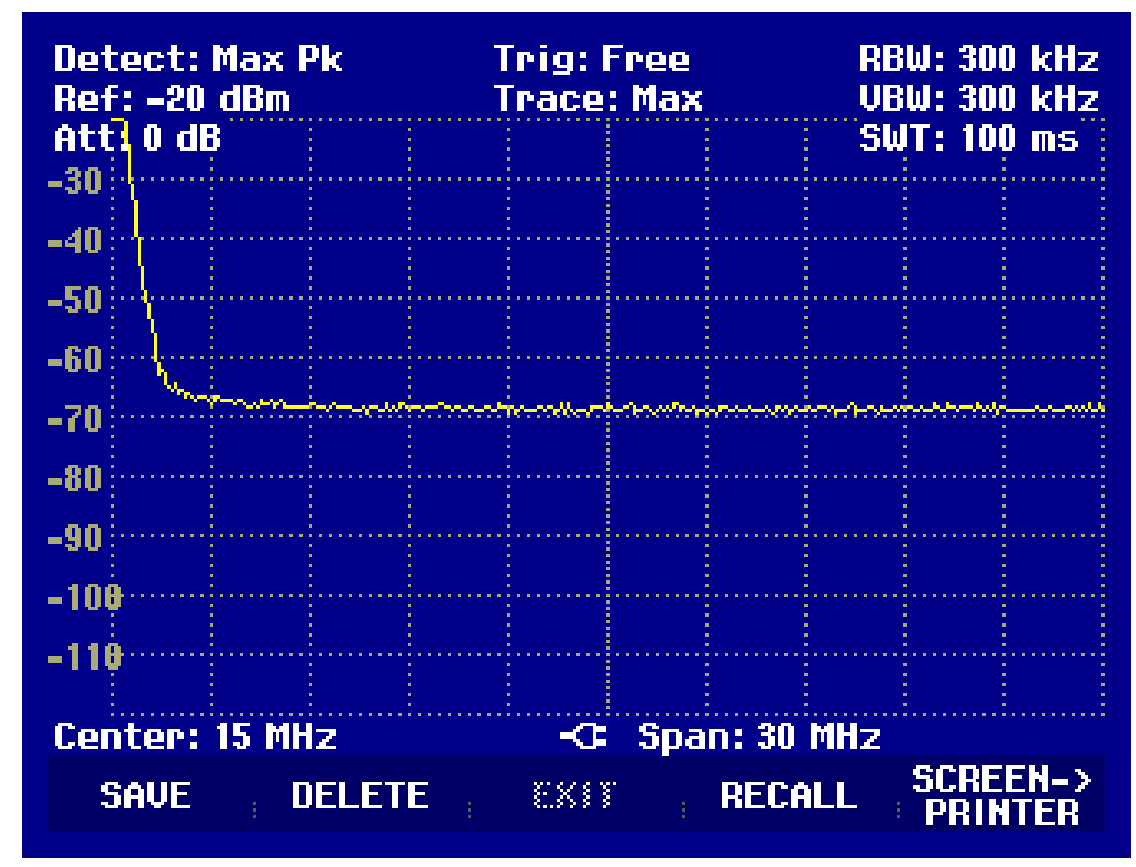

Figure 1: Spectrum centered at $15 \mathrm{MHz}$ and span $30 \mathrm{MHz}$ 


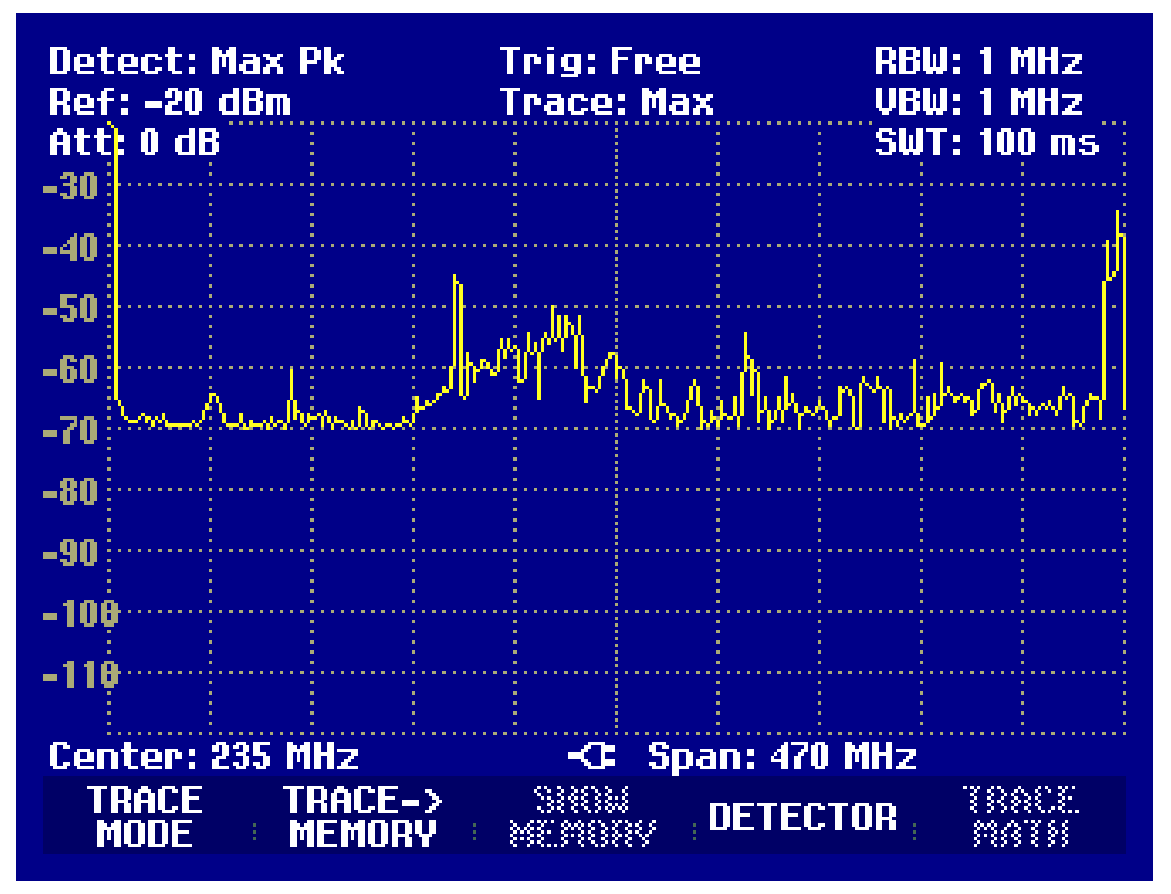

Figure 2: Spectrum centered at $235 \mathrm{MHz}$ and span $470 \mathrm{MHz}$

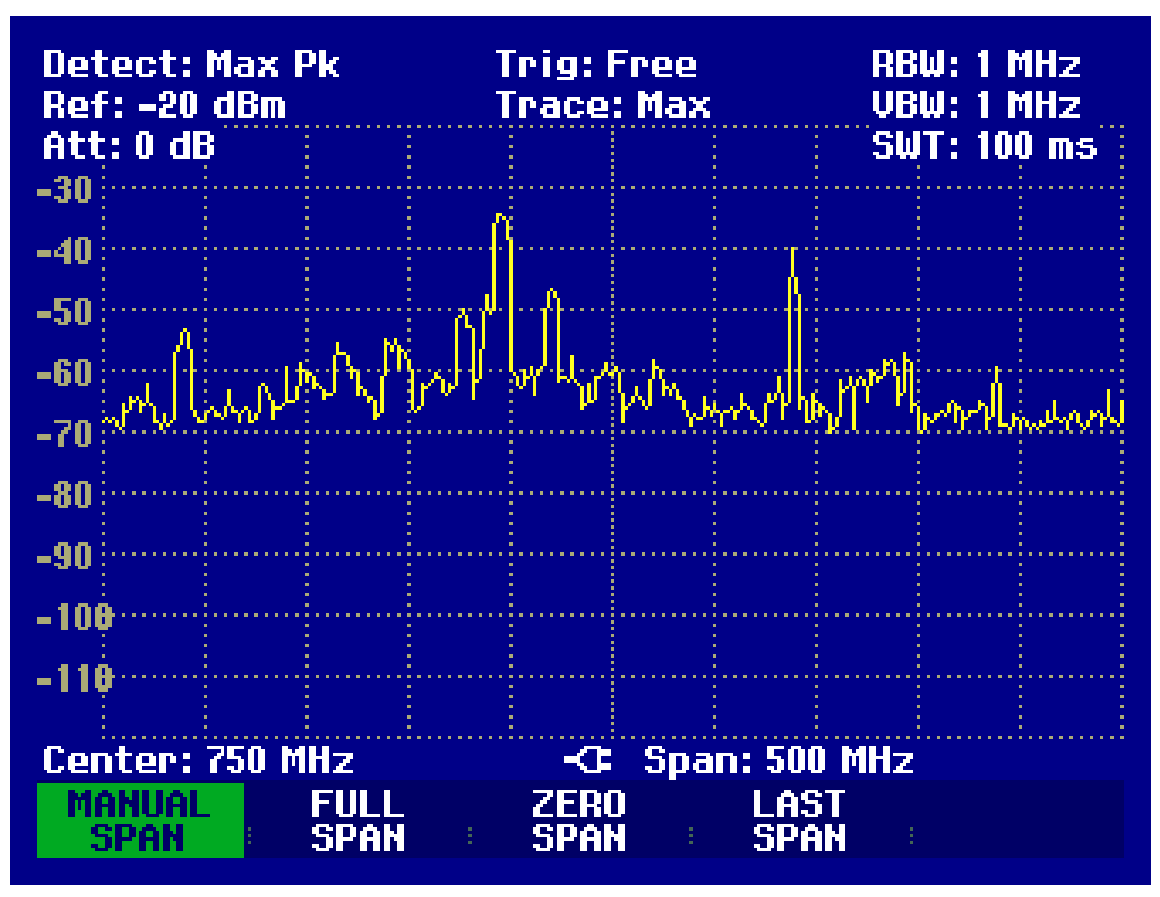

Figure 3: Spectrum centered at $750 \mathrm{MHz}$ and span $500 \mathrm{MHz}$ 


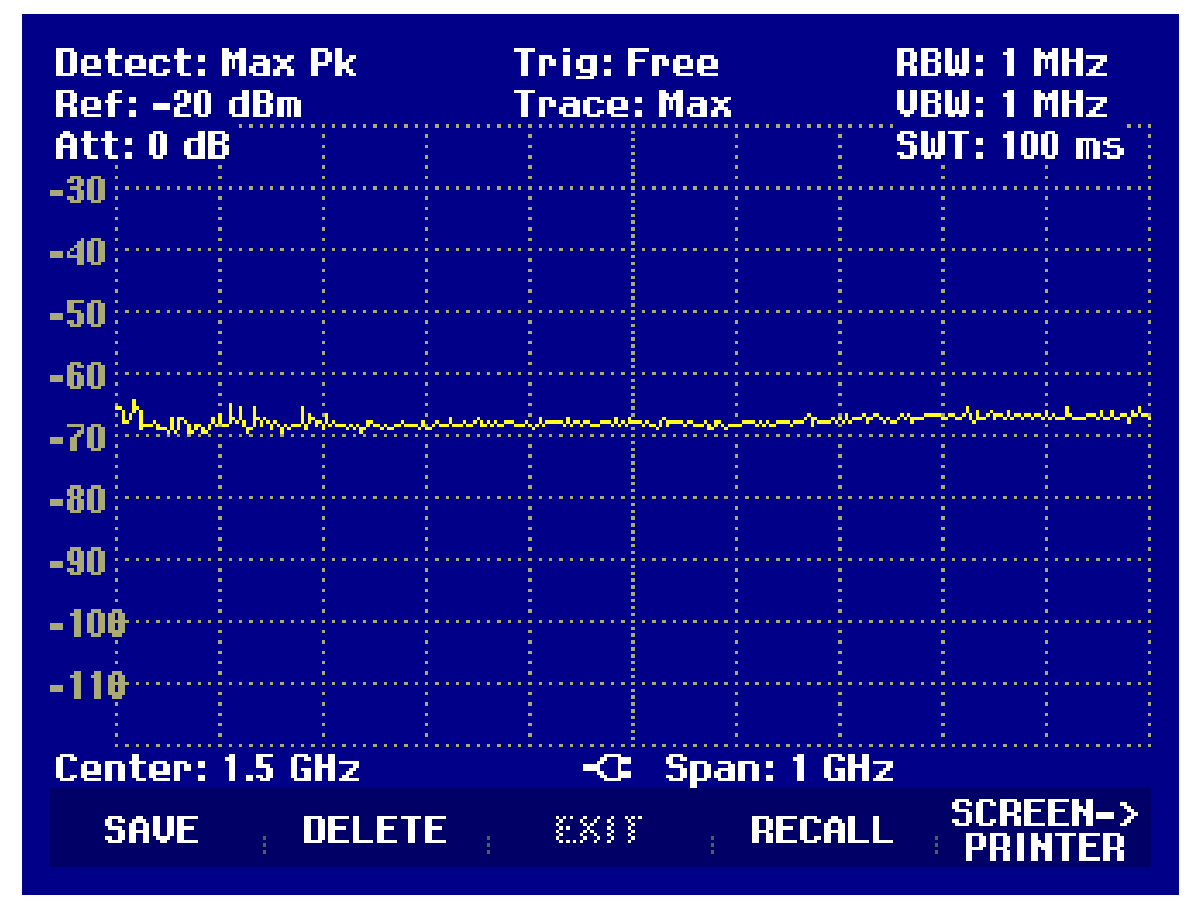

Figure 4: Spectrum centered at $1.5 \mathrm{GHz}$ and span $1 \mathrm{GHz}$

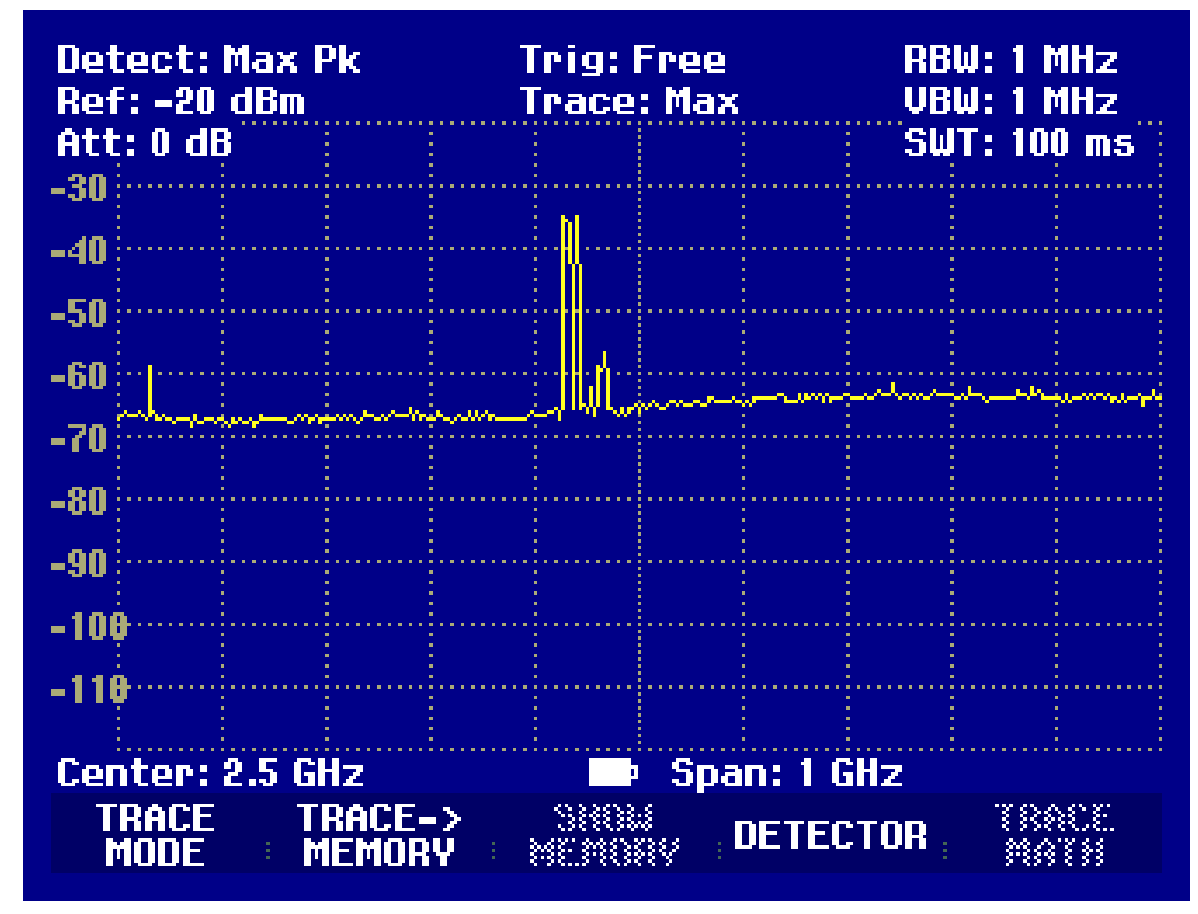

Figure 5: Spectrum centered at $2.5 \mathrm{GHz}$ and span $1 \mathrm{GHz}$ 


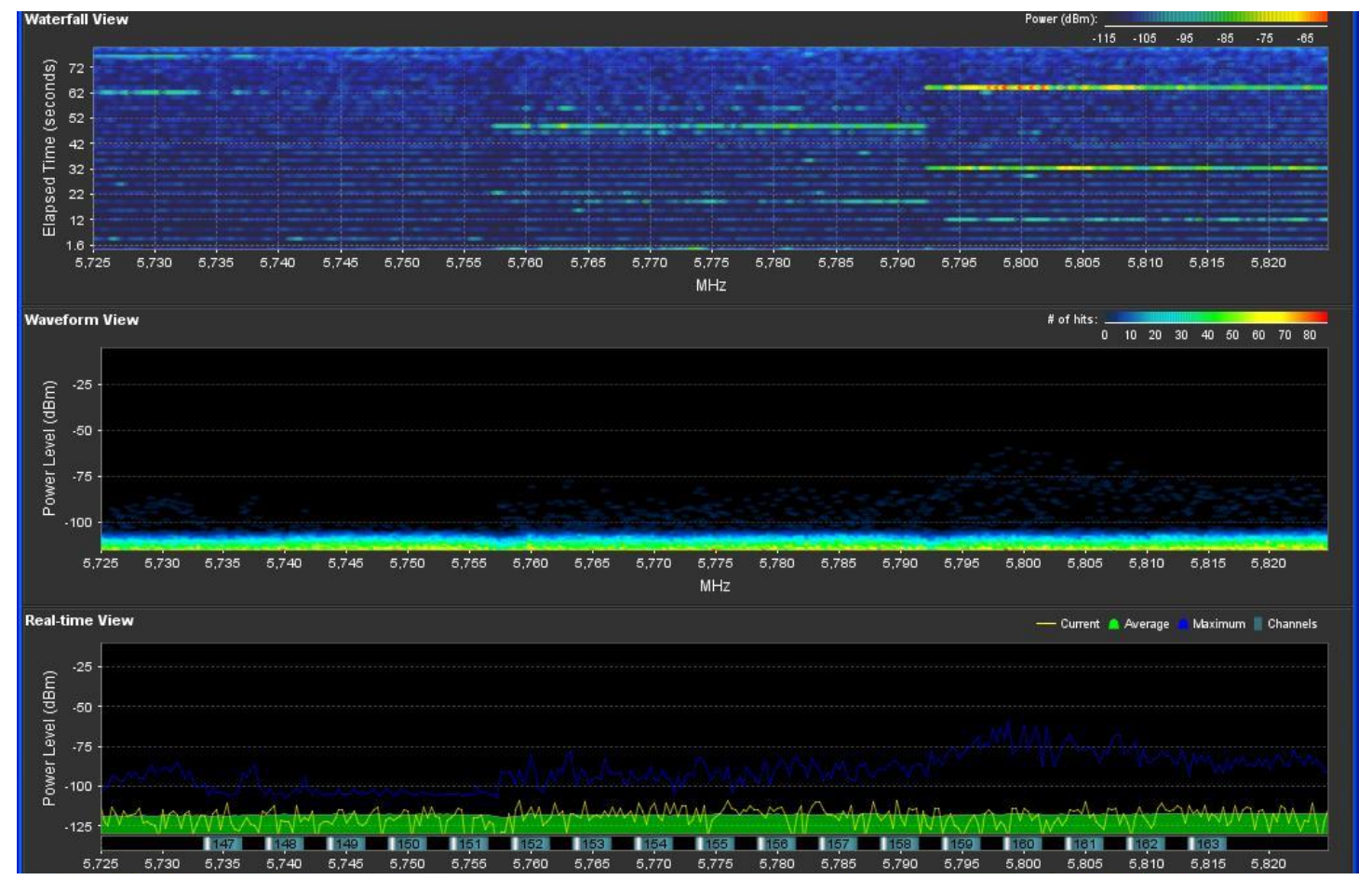

Figure 6: 5.8GHz Spectrum

\section{Location 2: Inside Basic Oxygen Processing Facility}

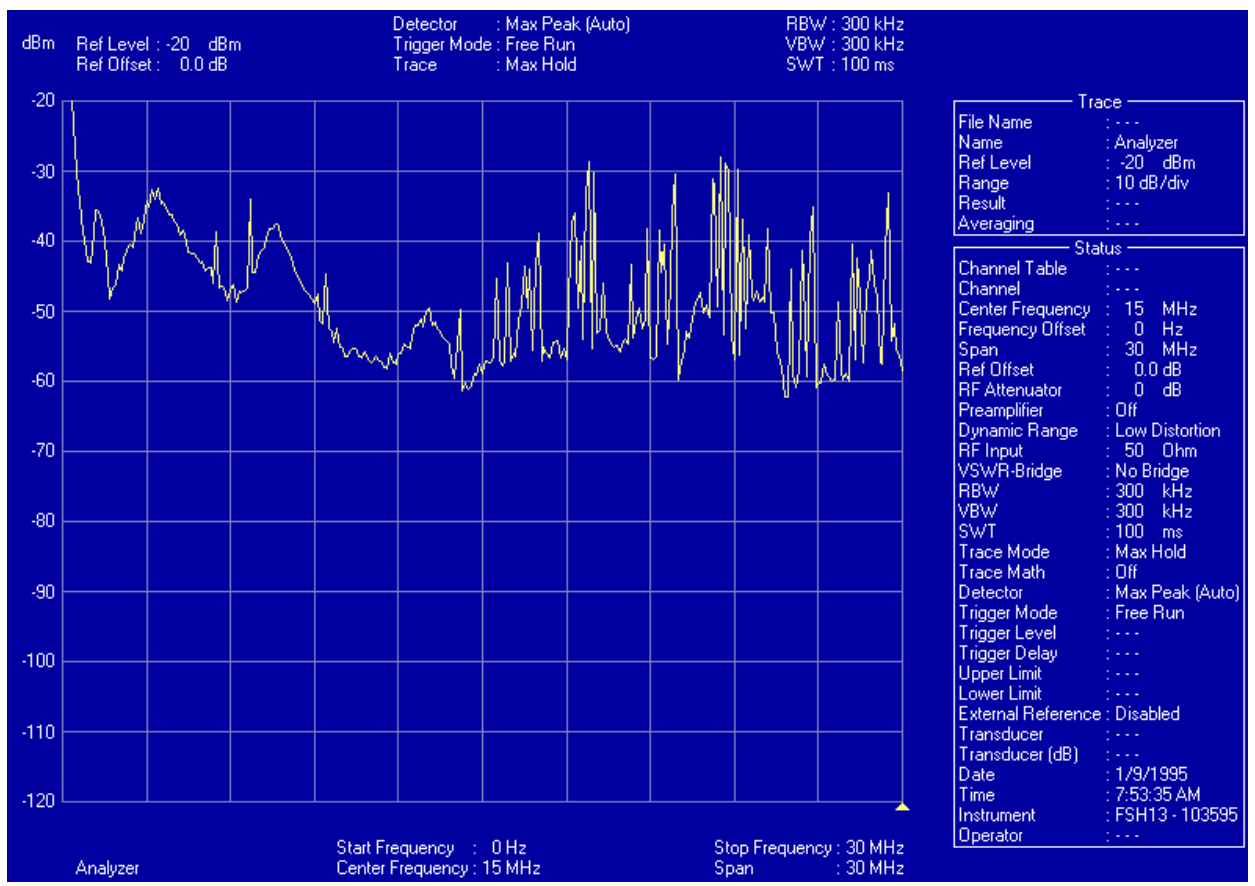

Figure 7: Spectrum centered at $15 \mathrm{MHz}$ and span $30 \mathrm{MHz}$ 


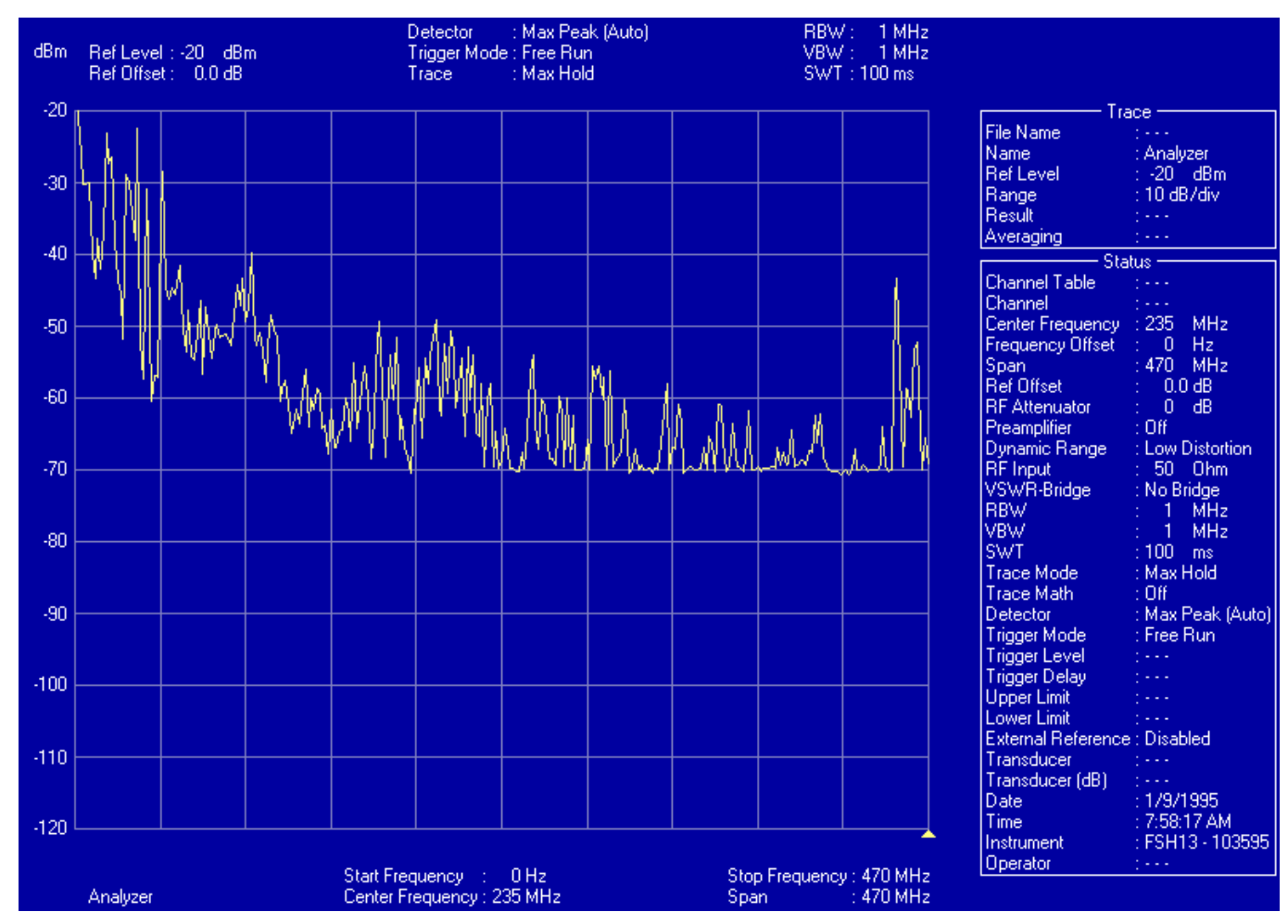

Figure 8: Spectrum centered at $235 \mathrm{MHz}$ and span $470 \mathrm{MHz}$

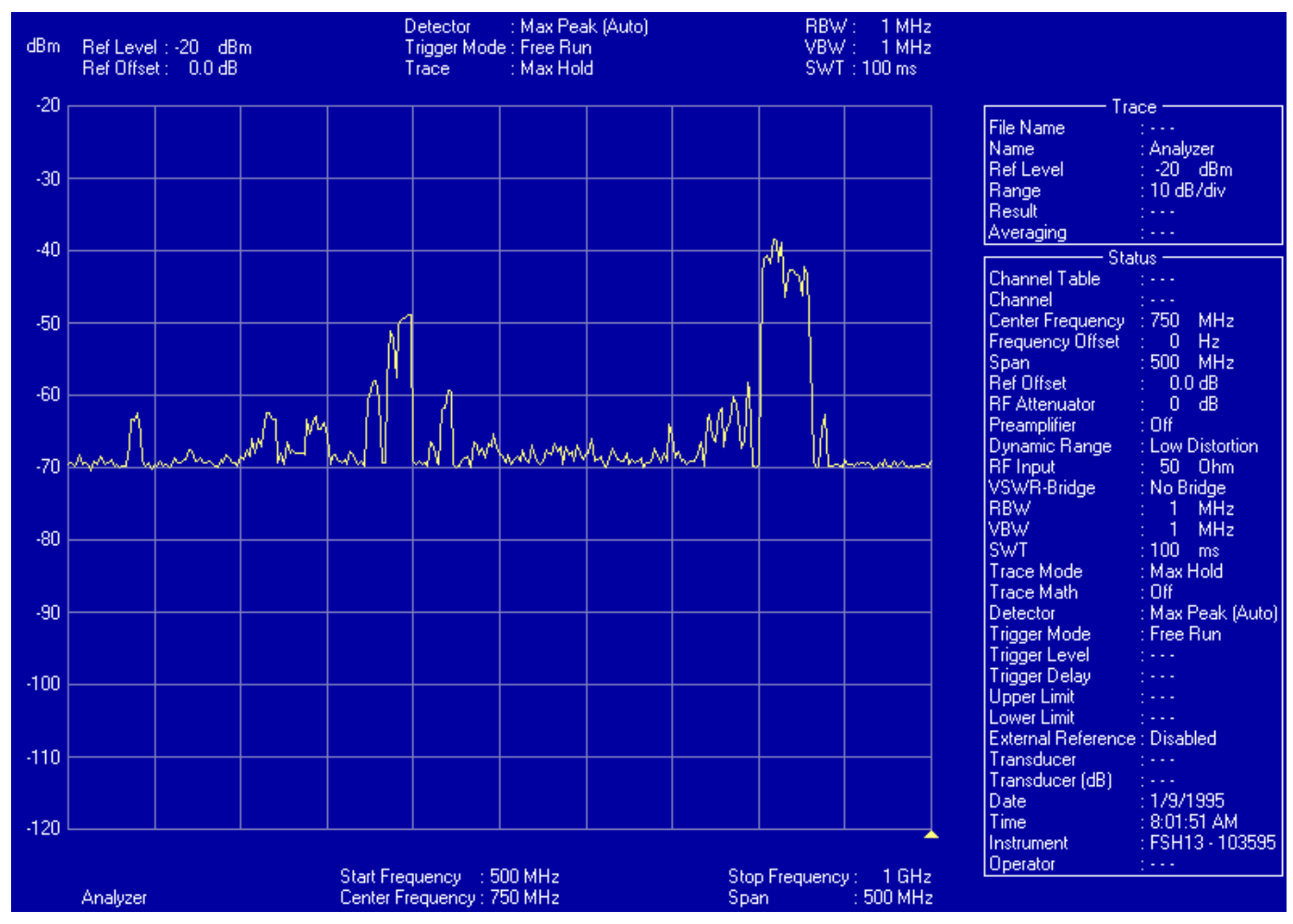

Figure 9: Spectrum centered at $750 \mathrm{MHz}$ and span $500 \mathrm{MHz}$ 


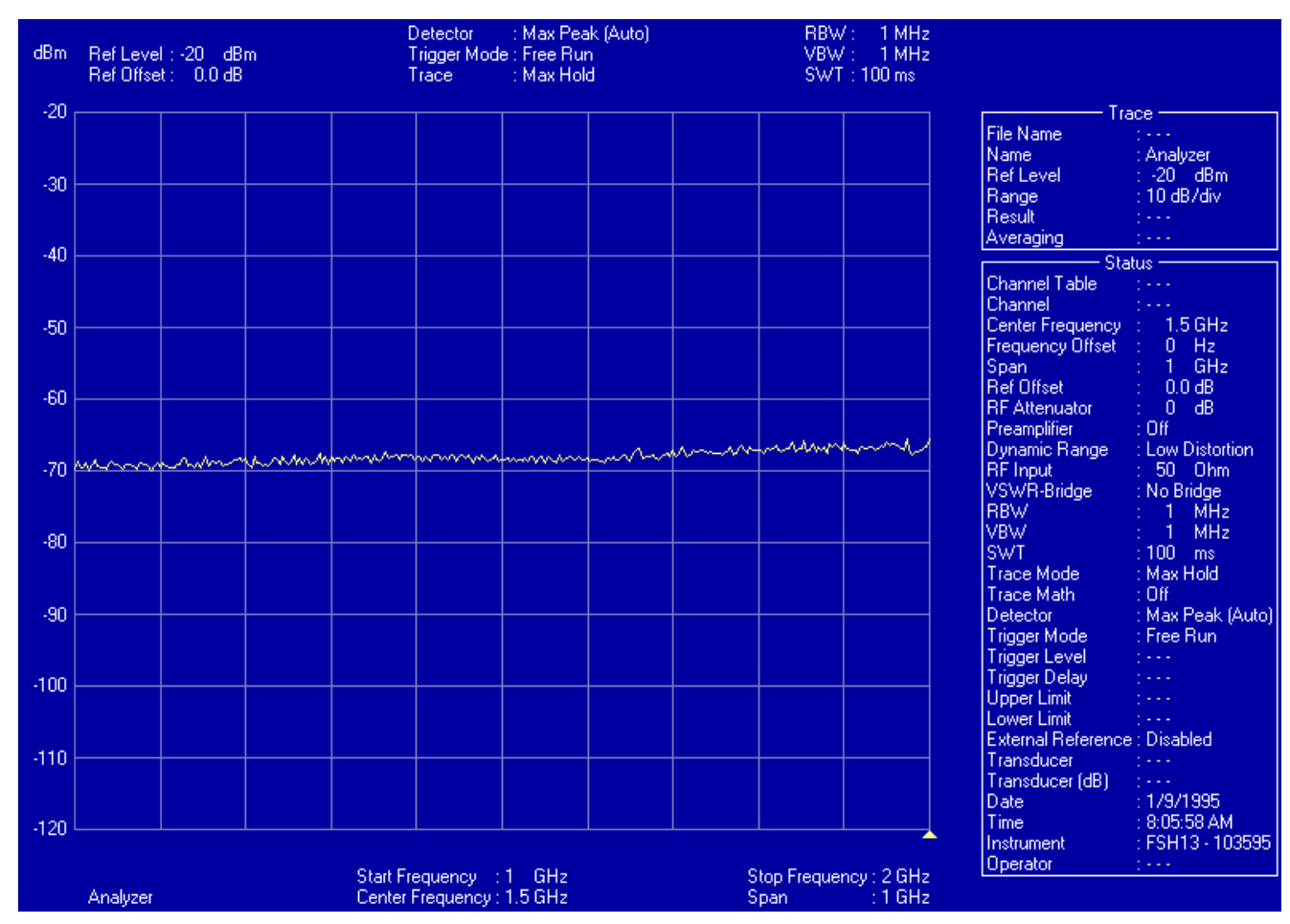

Figure 10: Spectrum centered at $1.5 \mathrm{GHz}$ and span $1 \mathrm{GHz}$

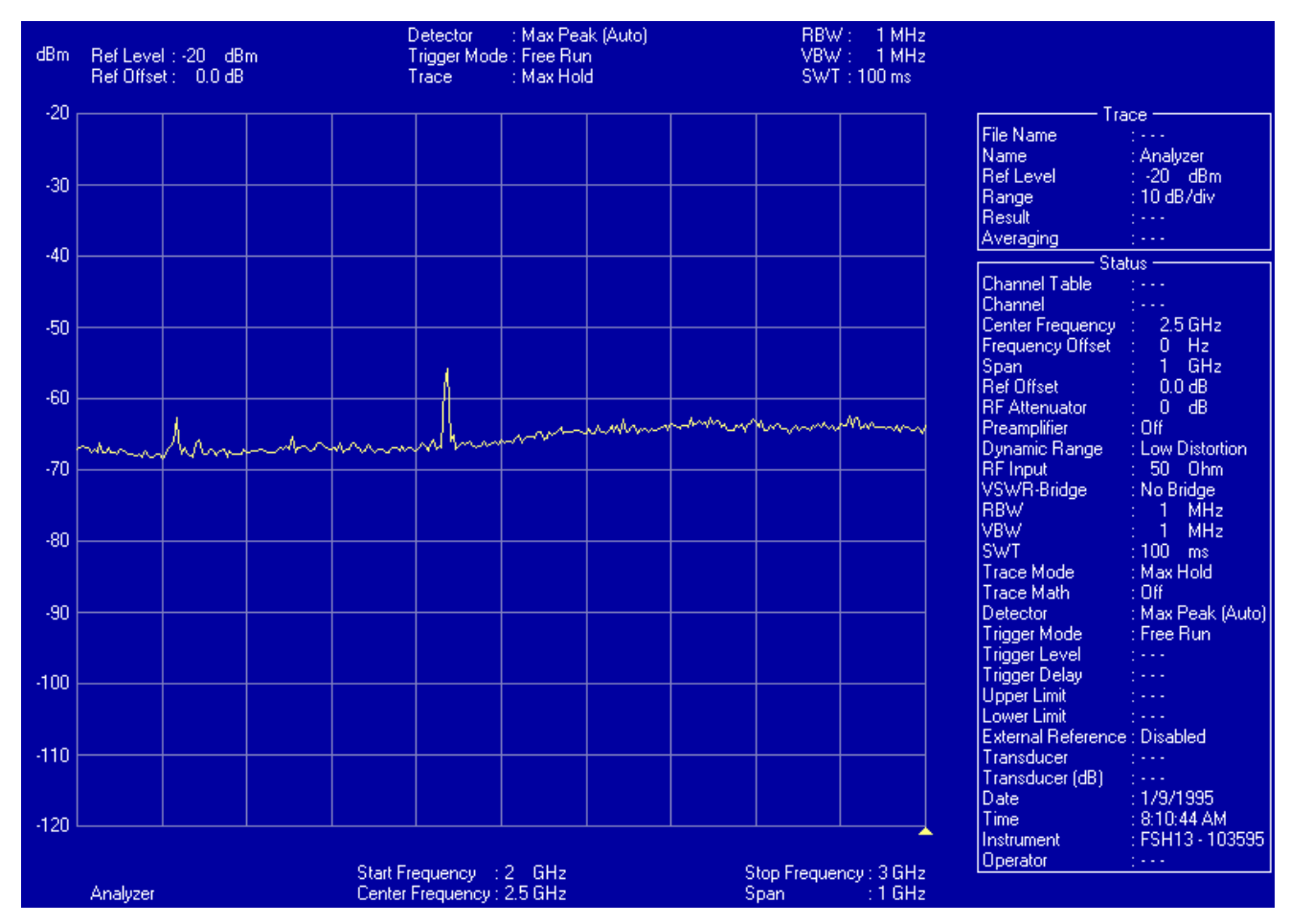

Figure 11: Spectrum centered at $2.5 \mathrm{GHz}$ and span $1 \mathrm{GHz}$ 


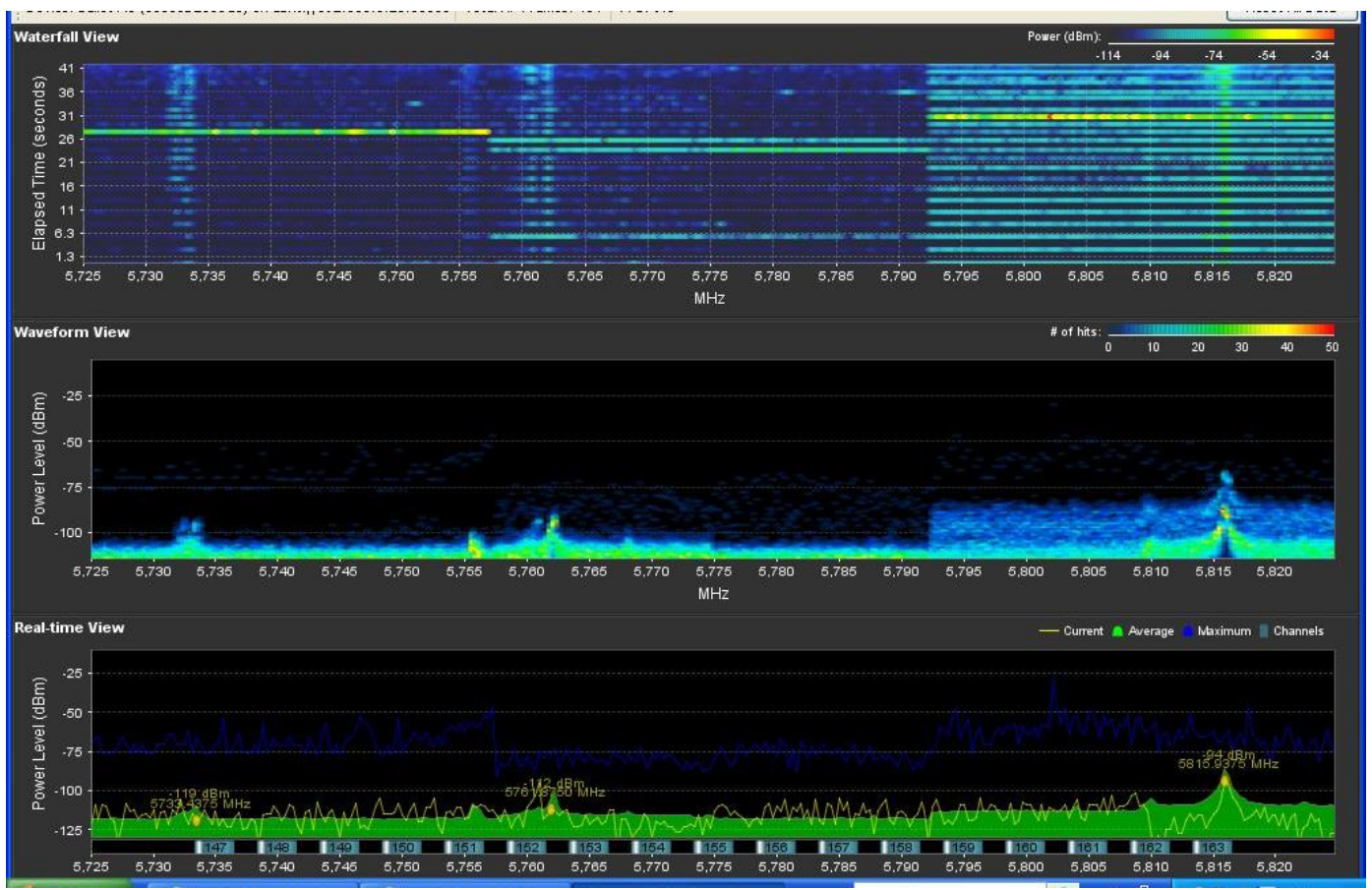

Figure 12: 5.8GHz Spectrum

\section{Location 3: Sixth Floor of Power House}

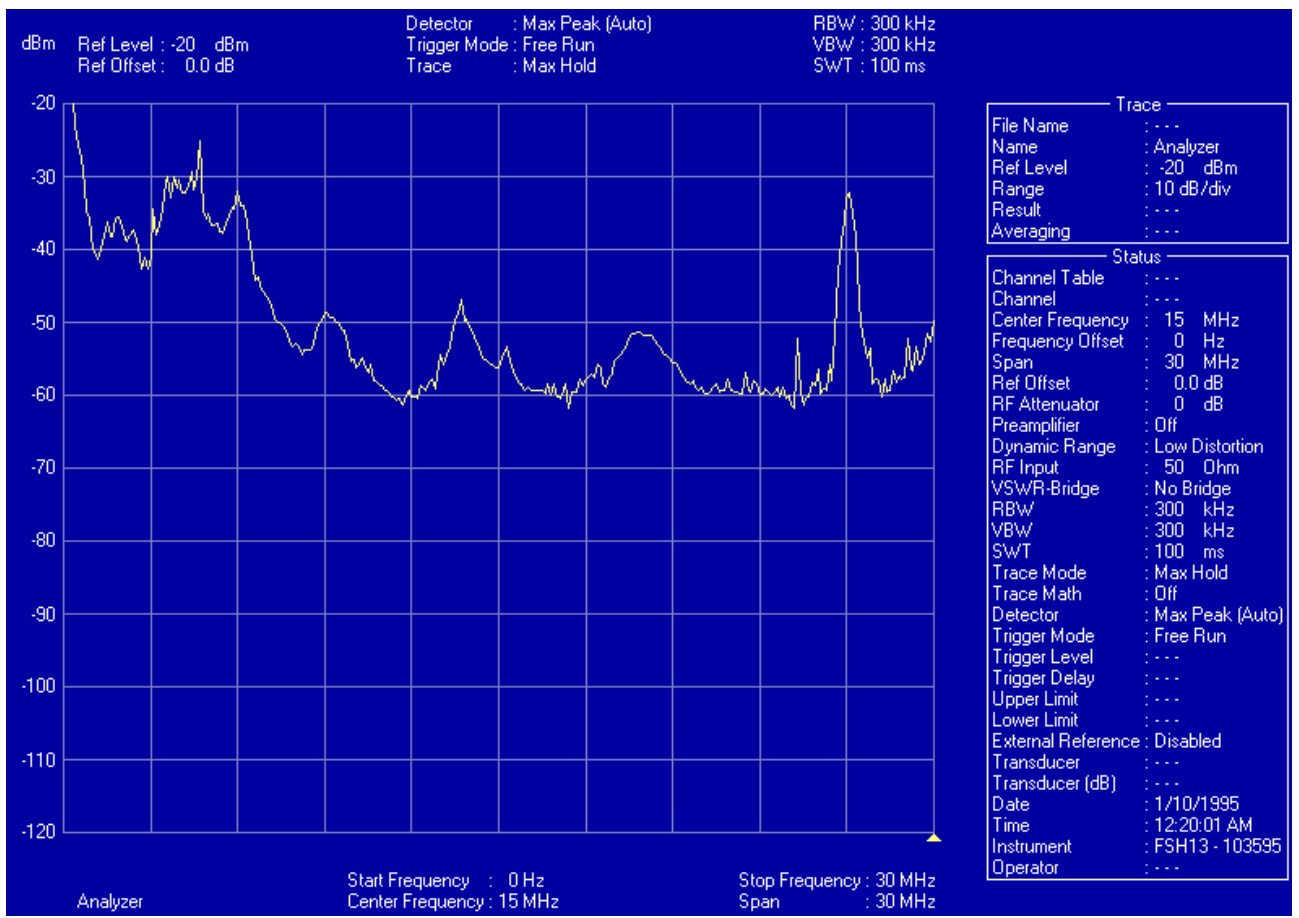

Figure 13: Spectrum centered at $15 \mathrm{MHz}$ and span $30 \mathrm{MHz}$ 


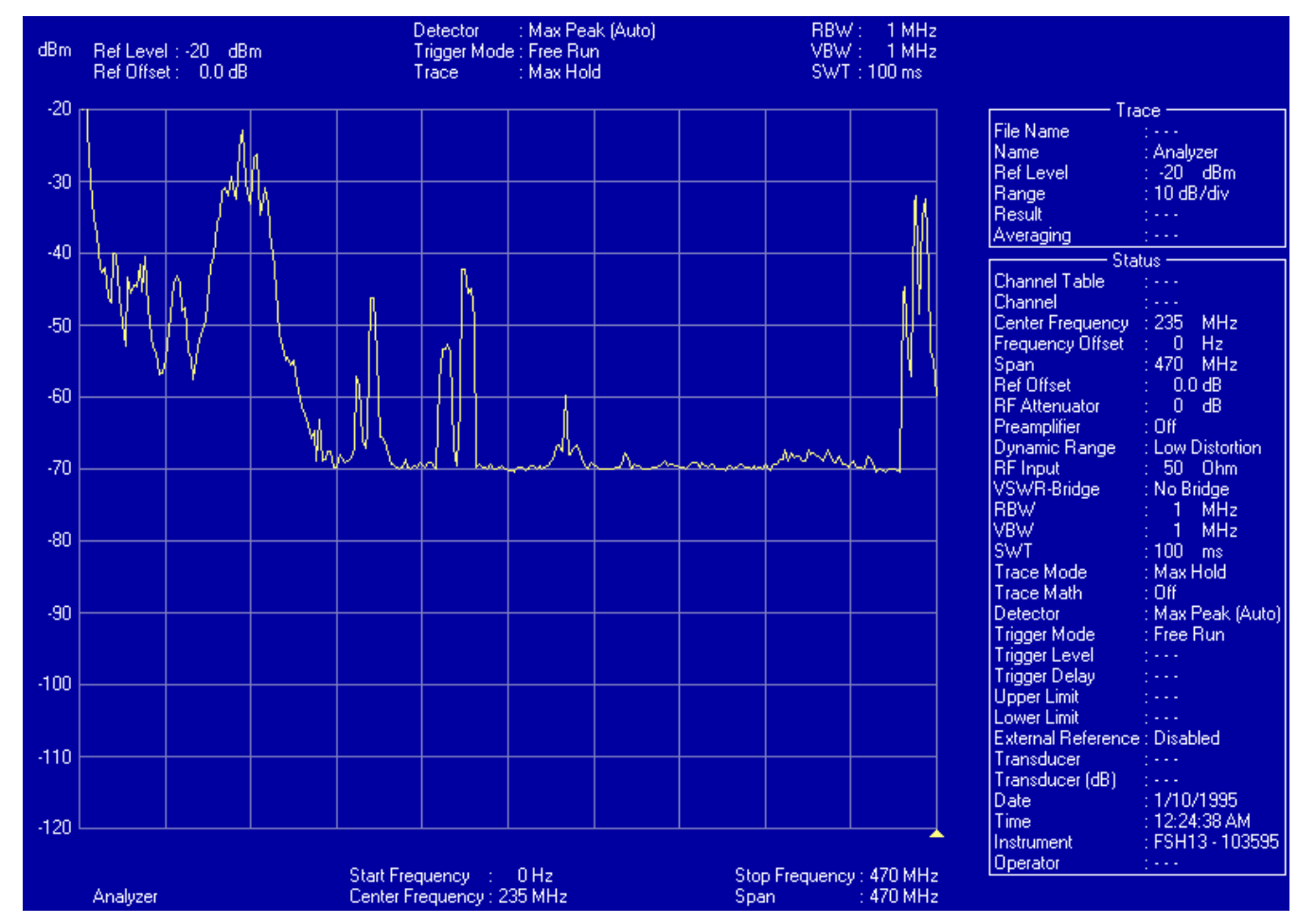

Figure 14: Spectrum centered at $235 \mathrm{MHz}$ and span $470 \mathrm{MHz}$

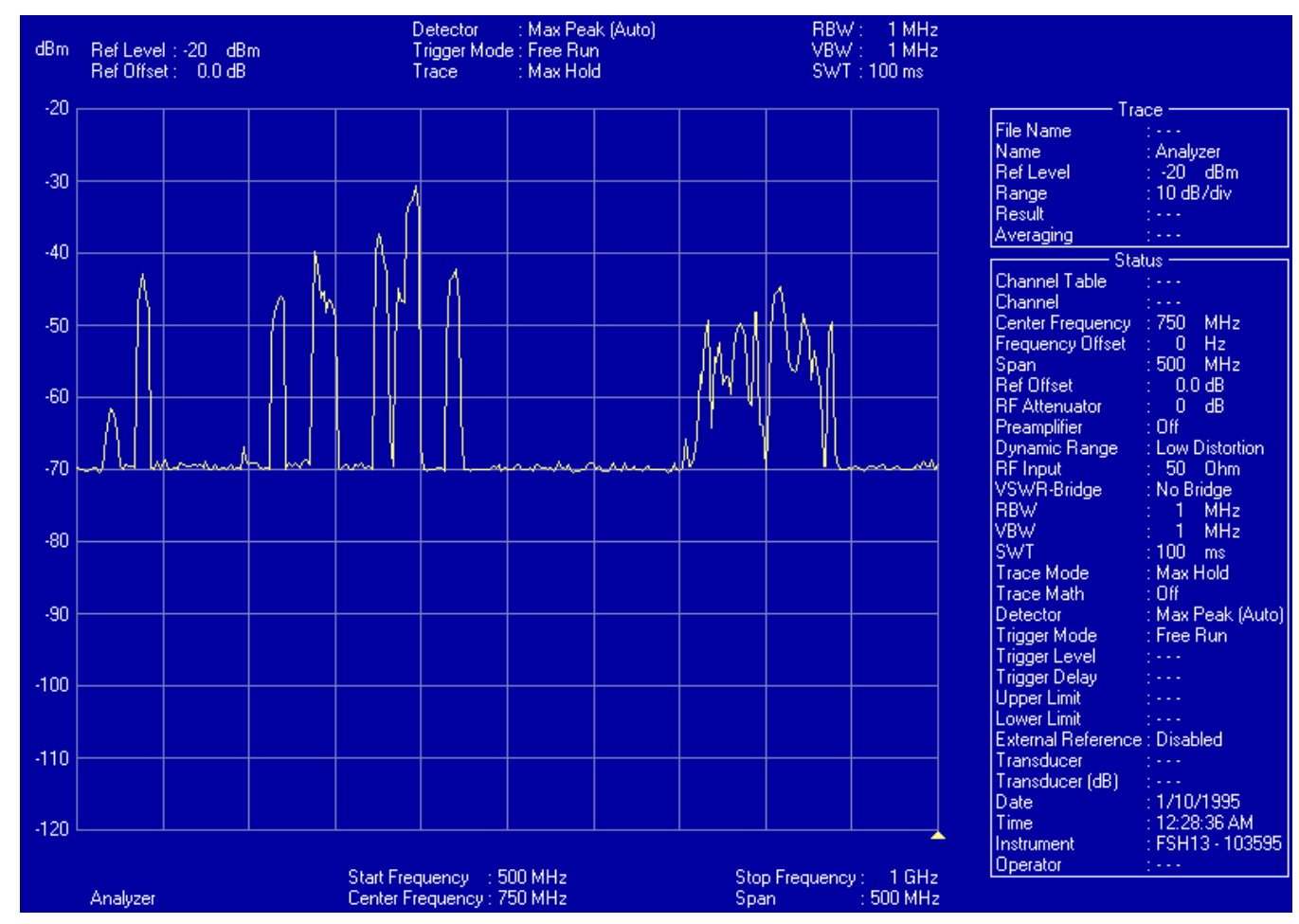

Figure 15: Spectrum centered at $750 \mathrm{MHz}$ and span $500 \mathrm{MHz}$ 


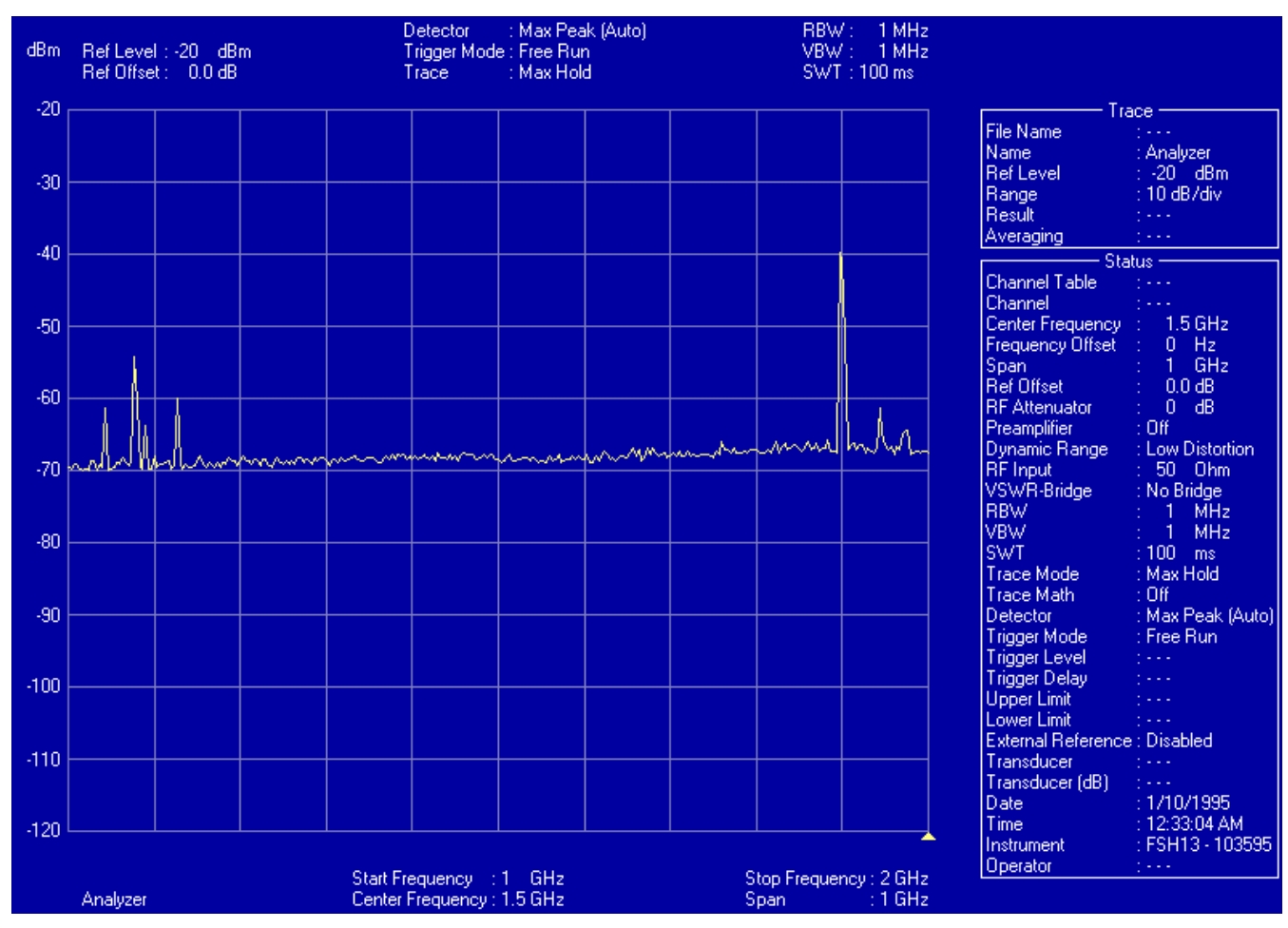

Figure16: Spectrum centered at $1.5 \mathrm{GHz}$ and span $1 \mathrm{GHz}$

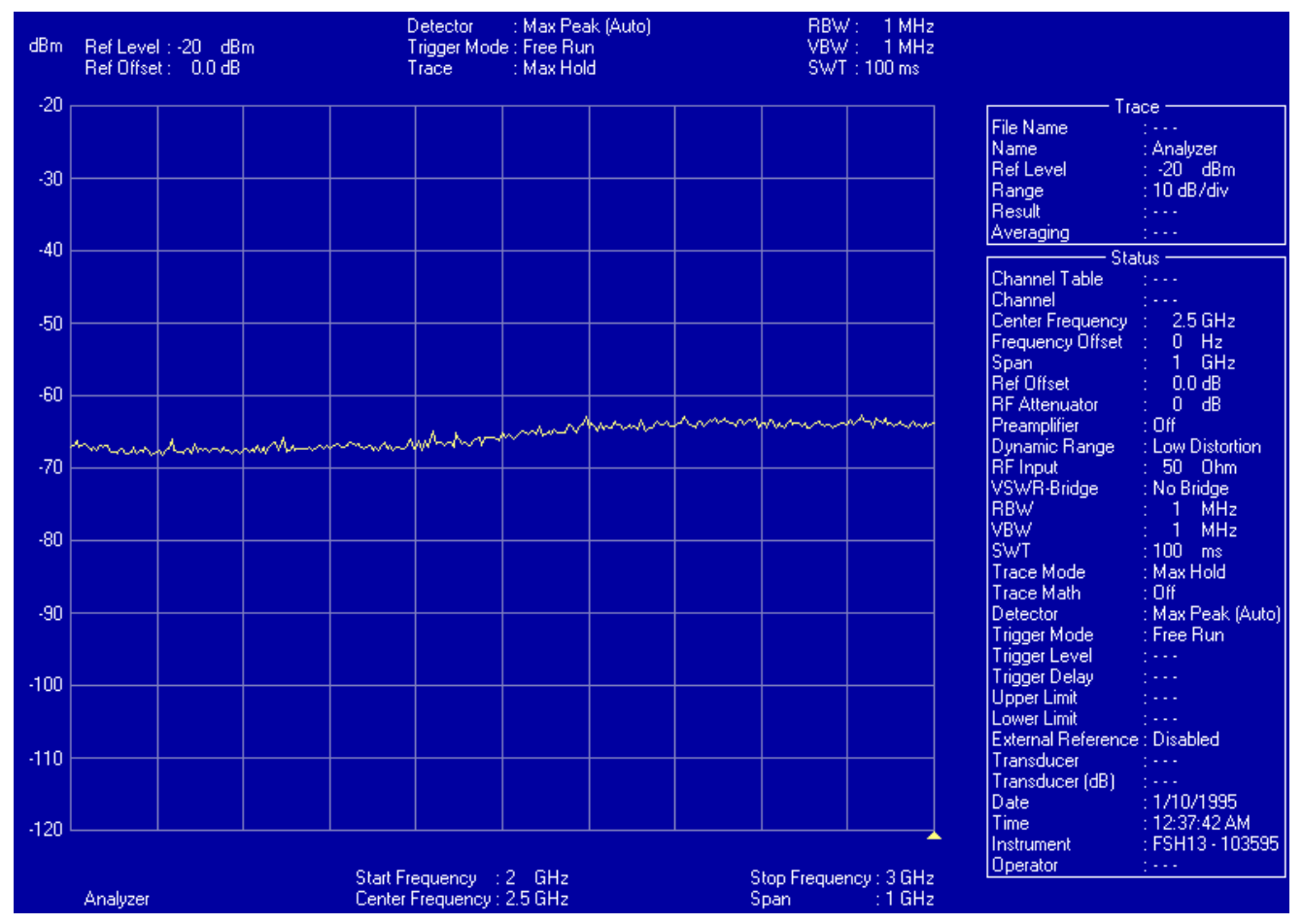

Figure17: Spectrum centered at $2.5 \mathrm{GHz}$ and span $1 \mathrm{GHz}$ 


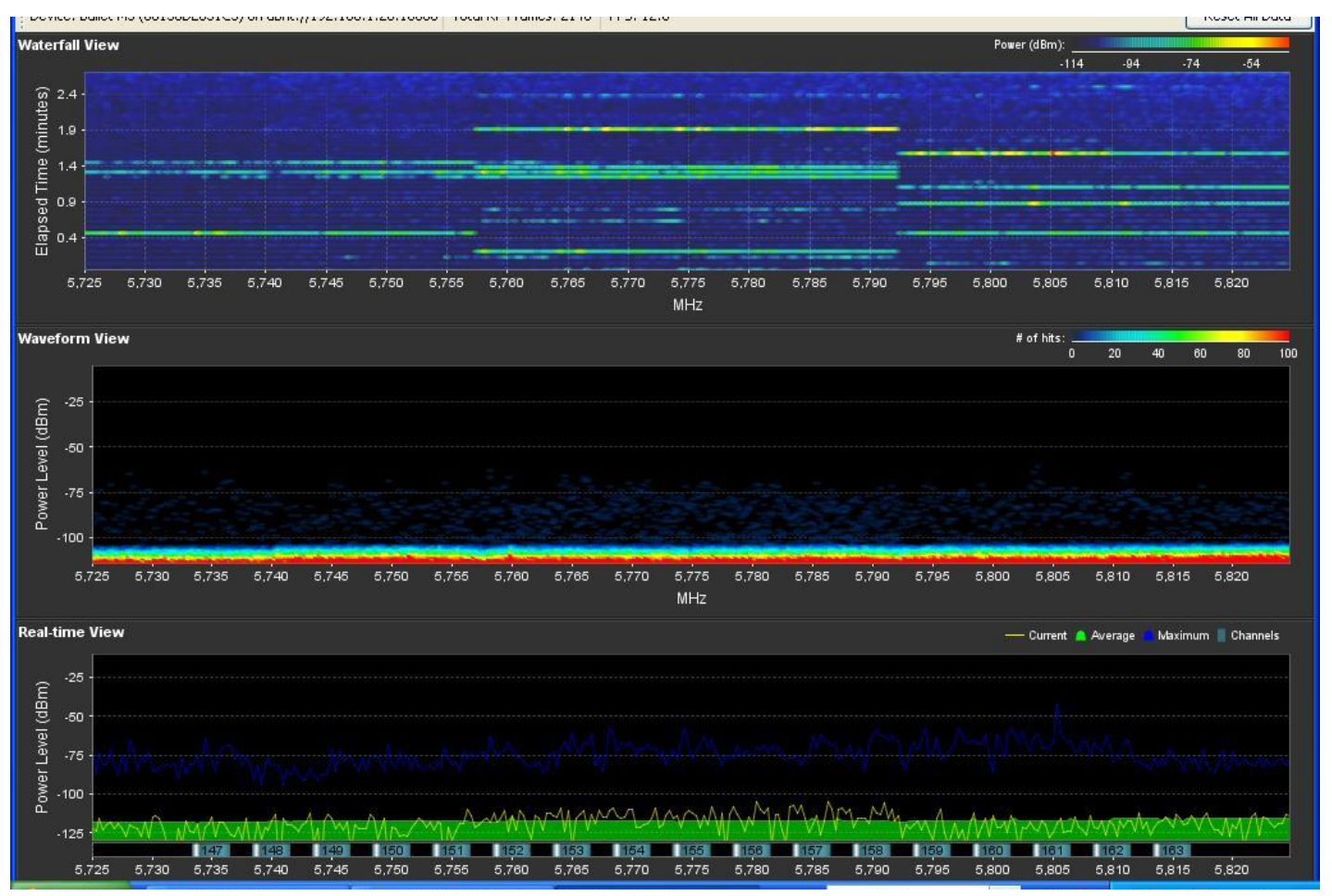

Figure18: 5.8GHz Spectrum

\section{Location 4: Caster Slab Nozzle}

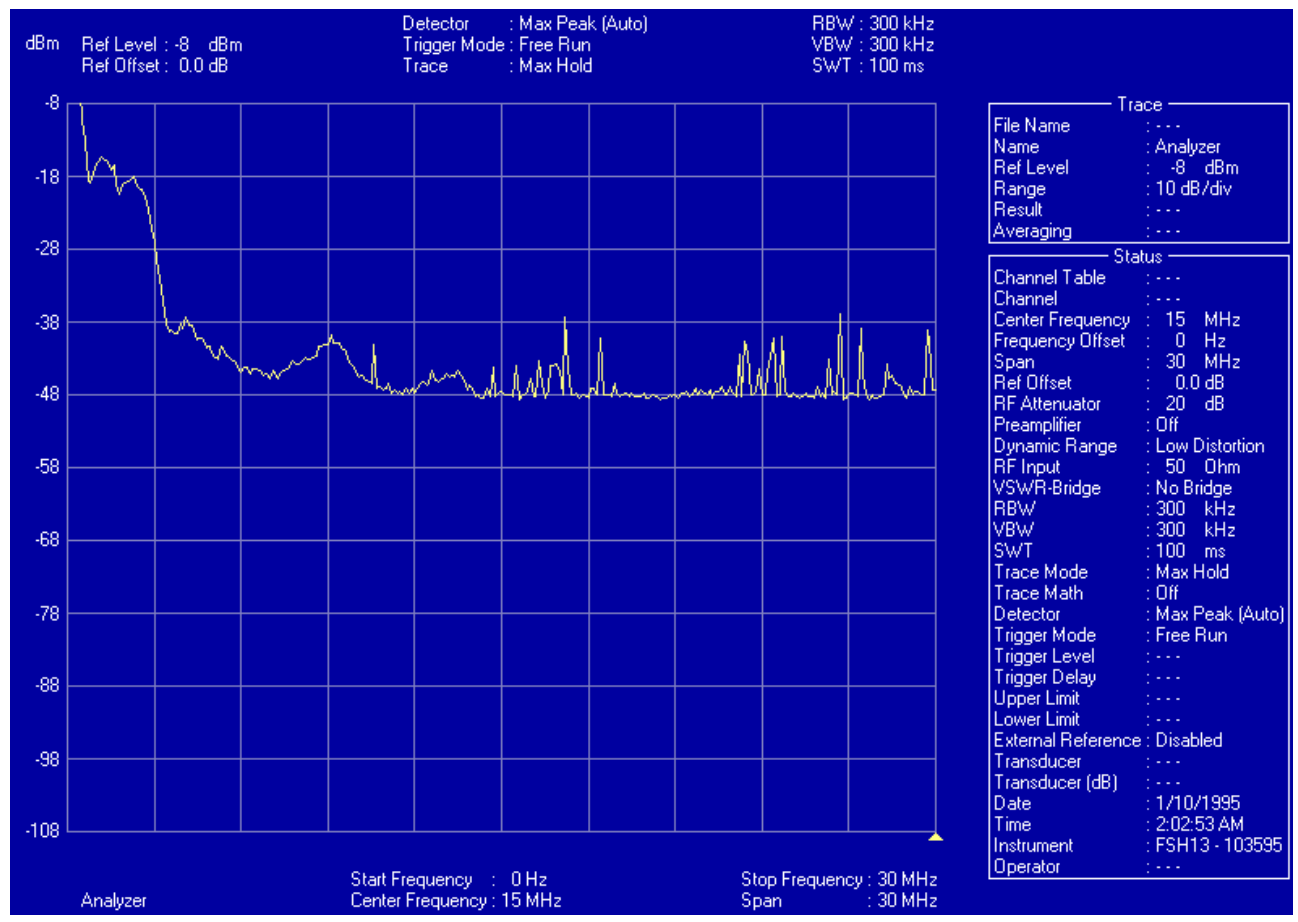

Figure 19: Spectrum centered at $15 \mathrm{MHz}$ and span $30 \mathrm{MHz}$ 


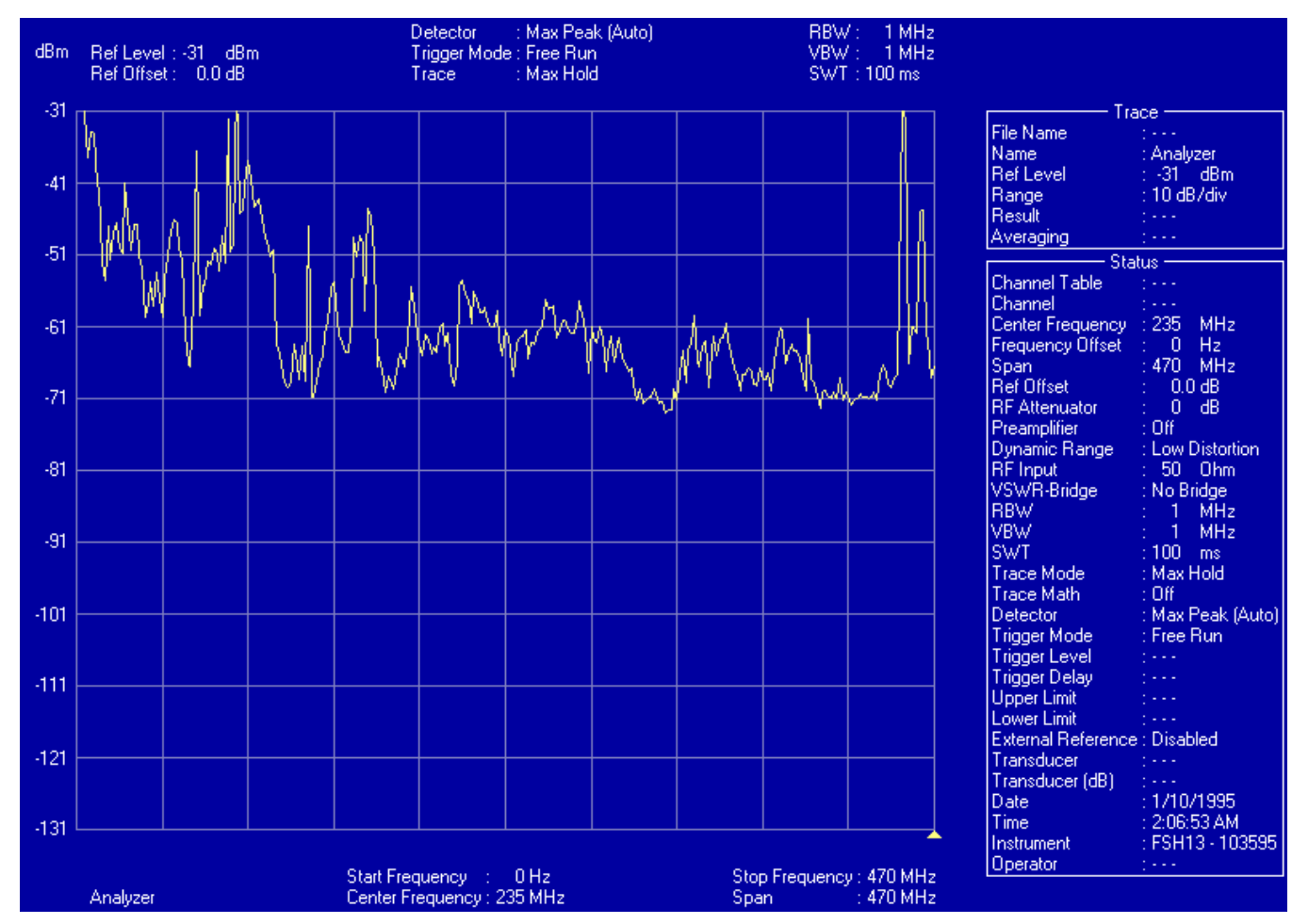

Figure 20: Spectrum centered at $235 \mathrm{MHz}$ and span $470 \mathrm{MHz}$

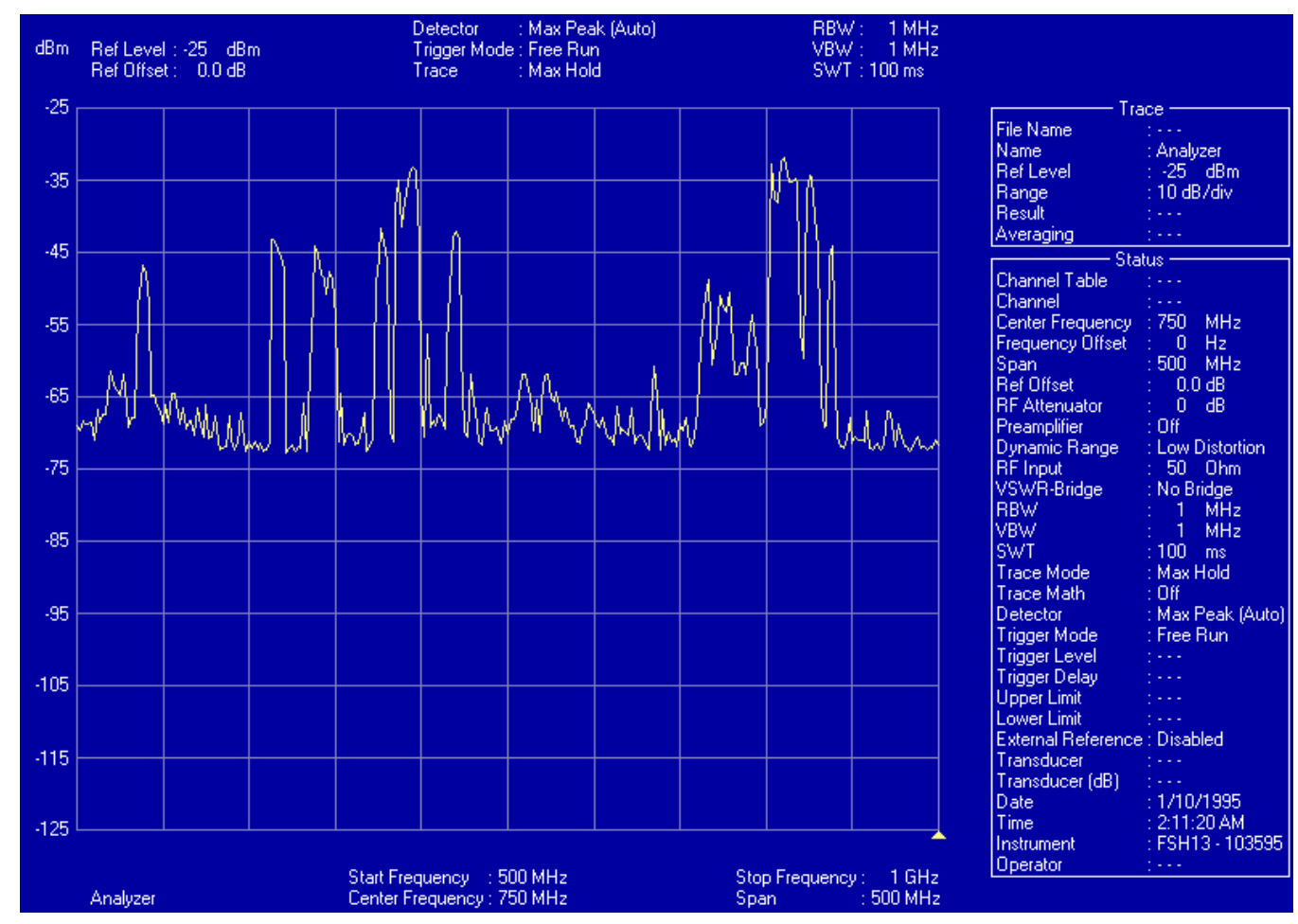

Figure 21: Spectrum centered at $750 \mathrm{MHz}$ and span $500 \mathrm{MHz}$ 


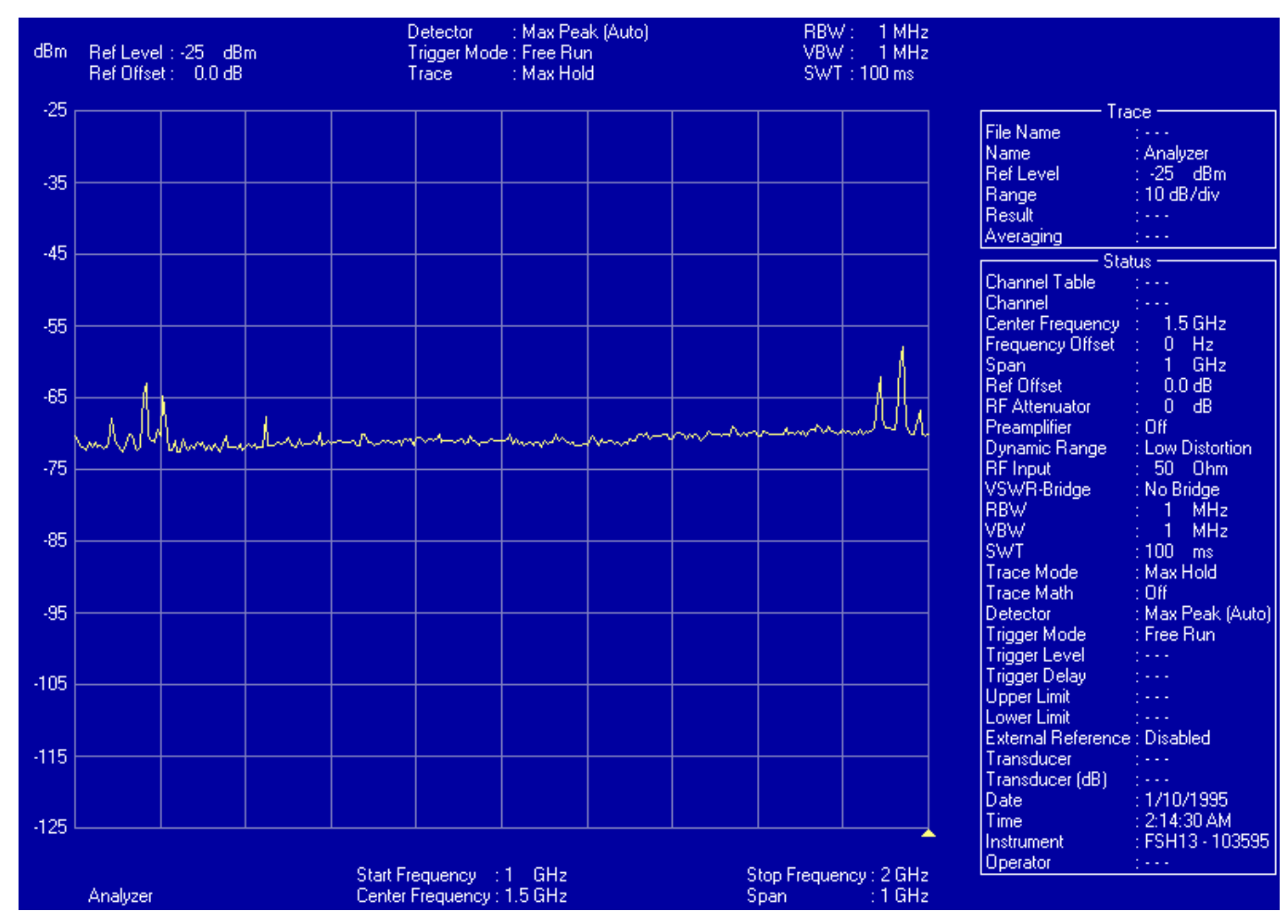

Figure 22: Spectrum centered at $1.5 \mathrm{GHz}$ and span $1 \mathrm{GHz}$

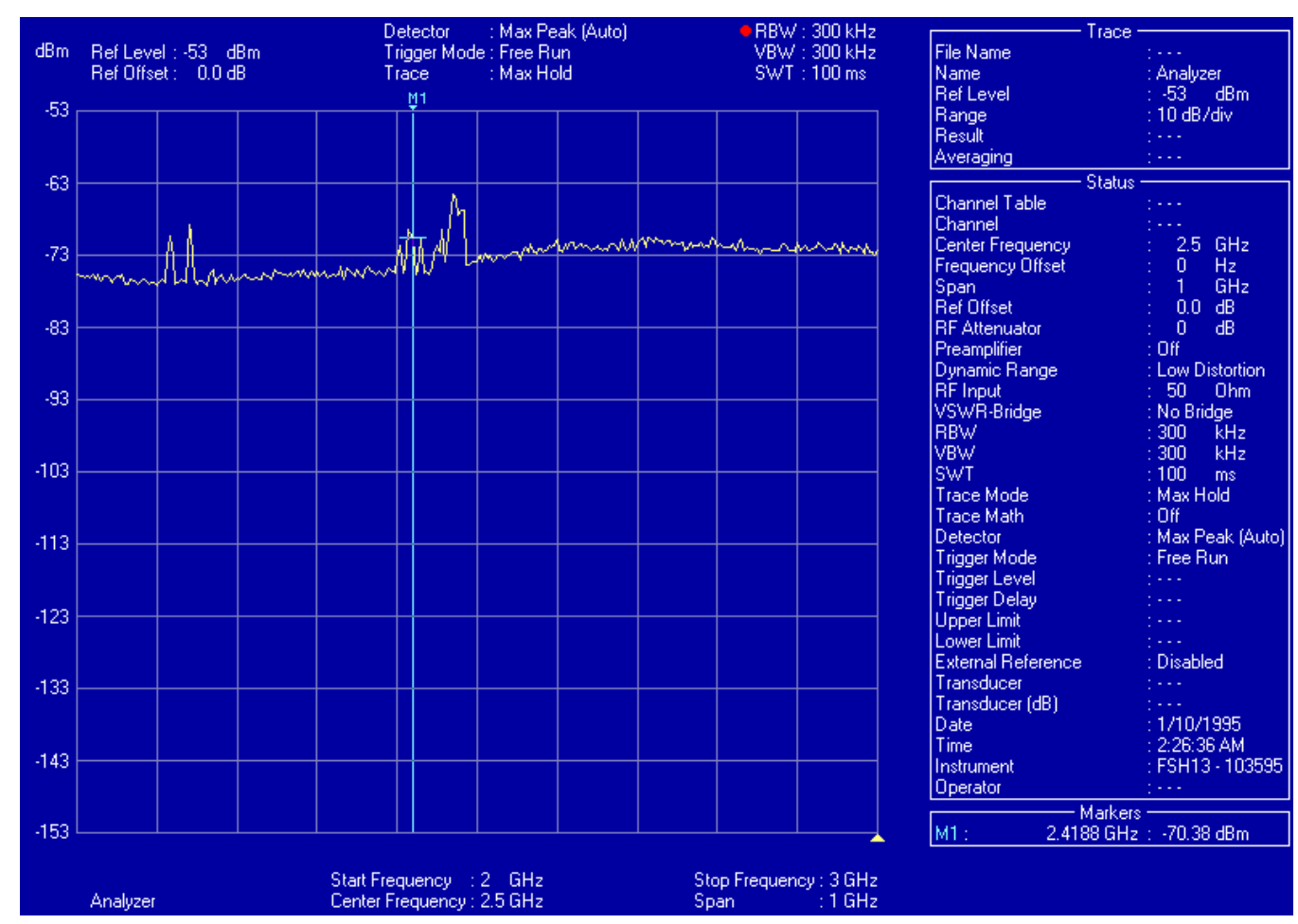

Figure 23: Spectrum centered at $2.5 \mathrm{GHz}$ and span $1 \mathrm{GHz}$ 


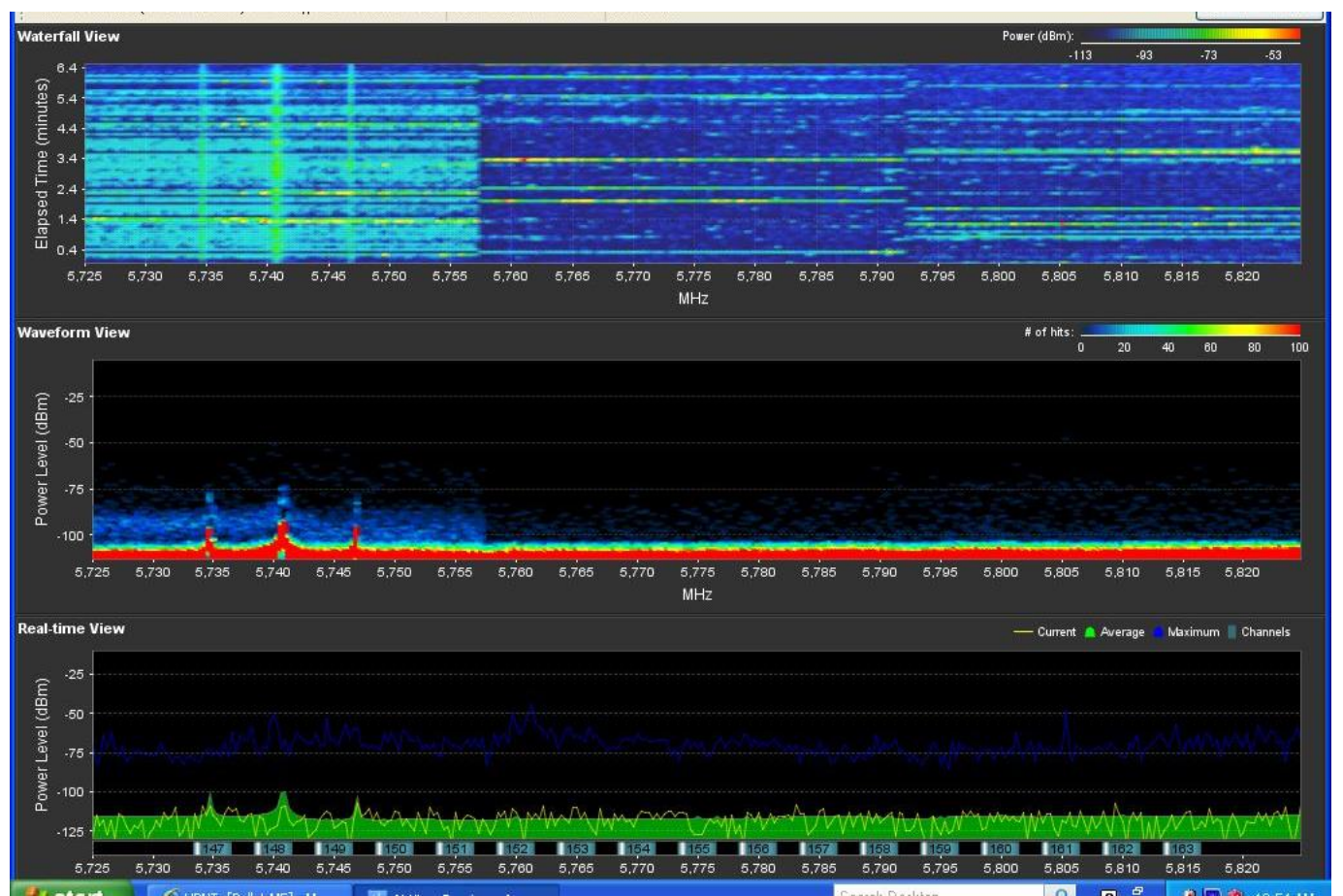

Figure 24: 5.8GHz Spectrum

\section{Location 5: Caster Compressor}

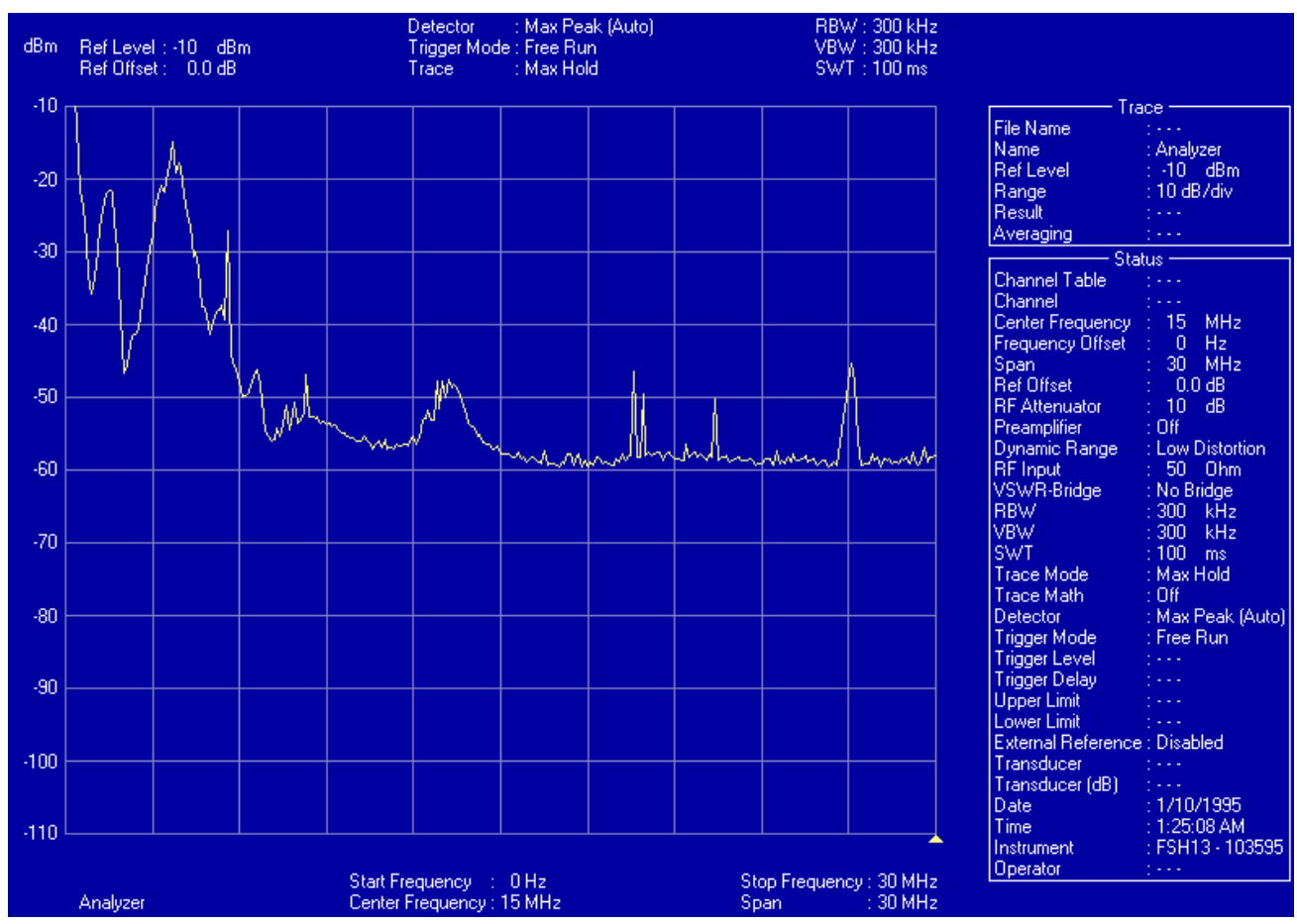

Figure 25: Spectrum centered at $15 \mathrm{MHz}$ and span $30 \mathrm{MHz}$ 


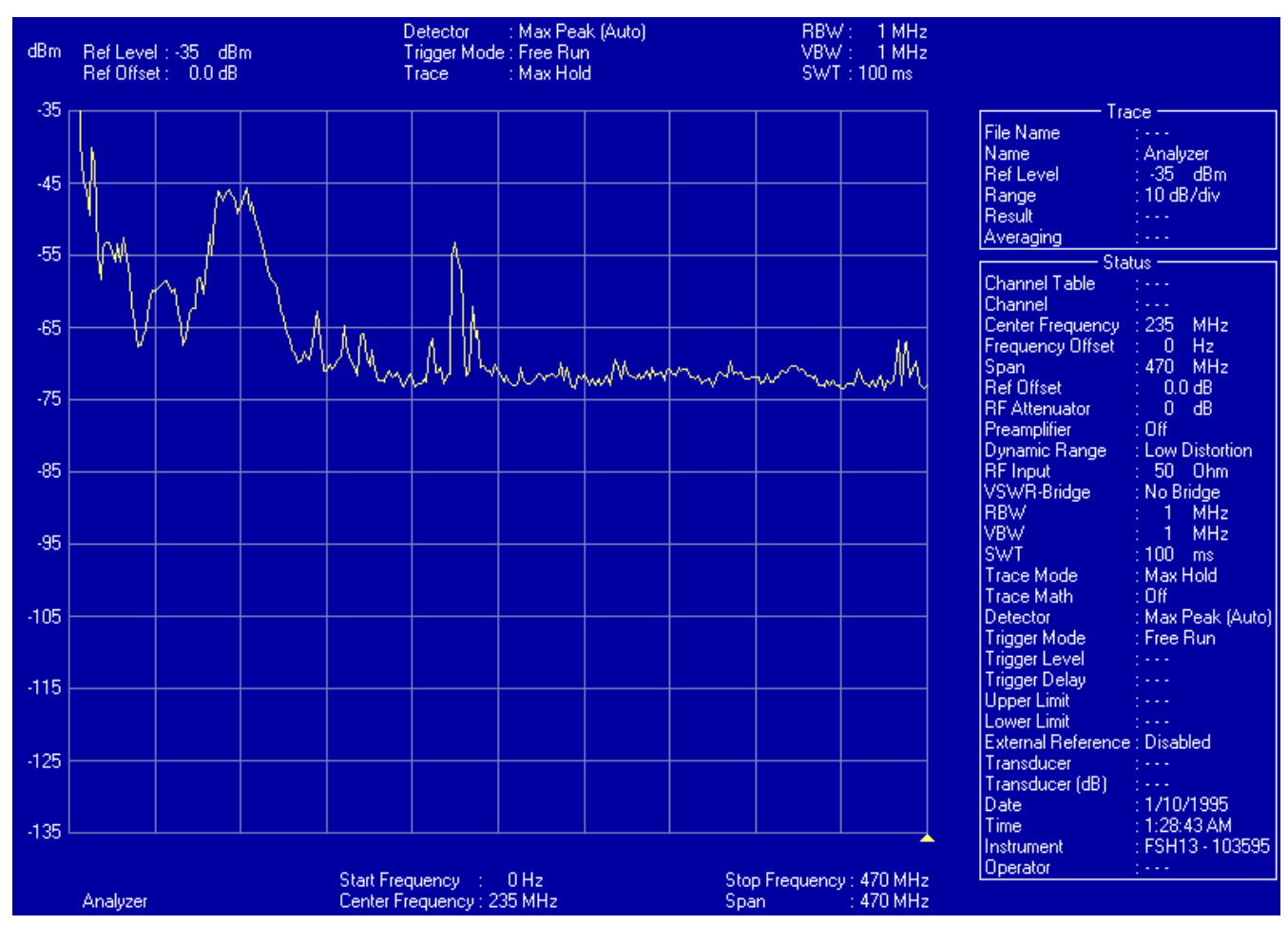

Figure 26: Spectrum centered at $235 \mathrm{MHz}$ and span $470 \mathrm{MHz}$

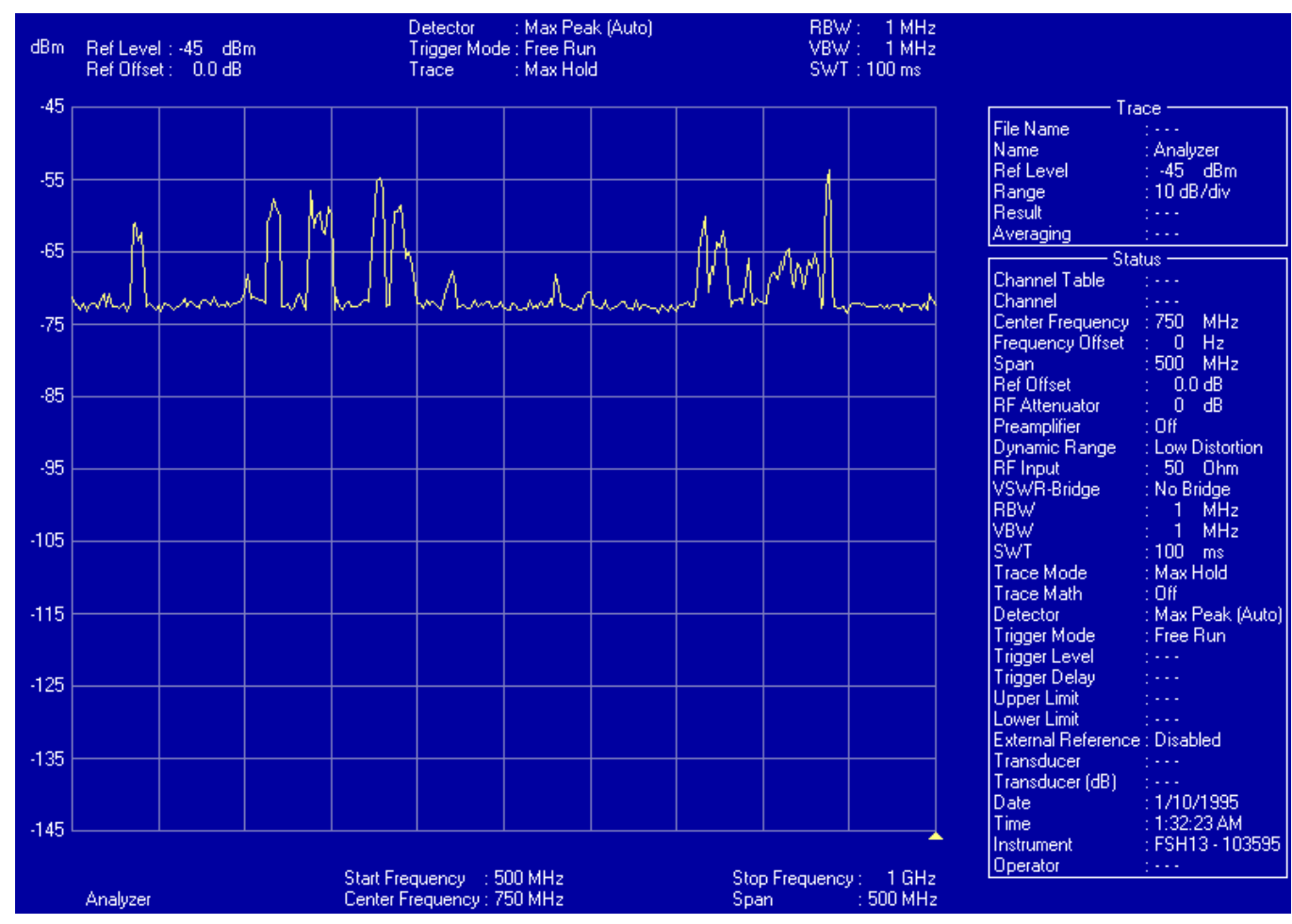

Figure 27: Spectrum centered at $750 \mathrm{MHz}$ and span $500 \mathrm{MHz}$ 


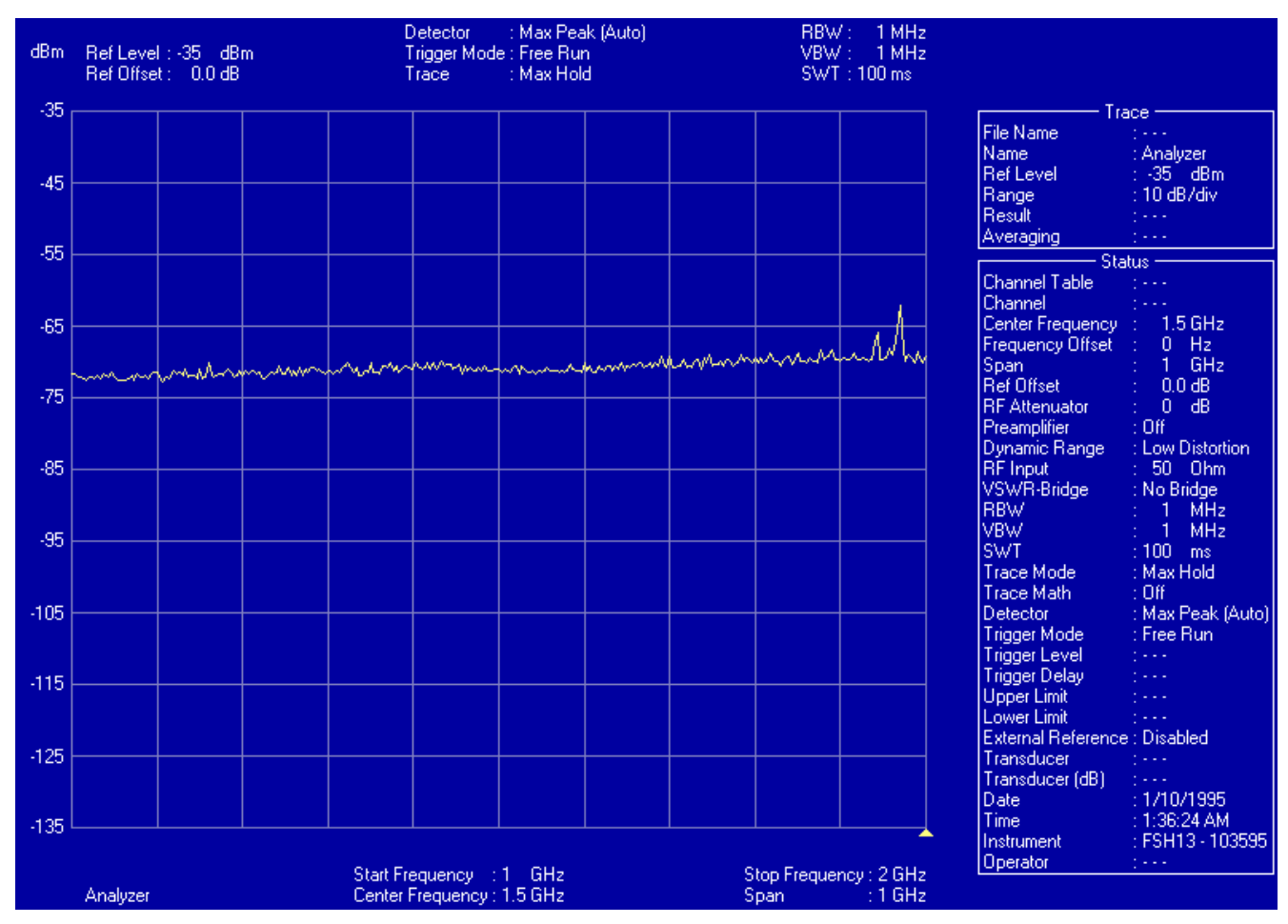

Figure 28: Spectrum centered at $1.5 \mathrm{GHz}$ and span $1 \mathrm{GHz}$

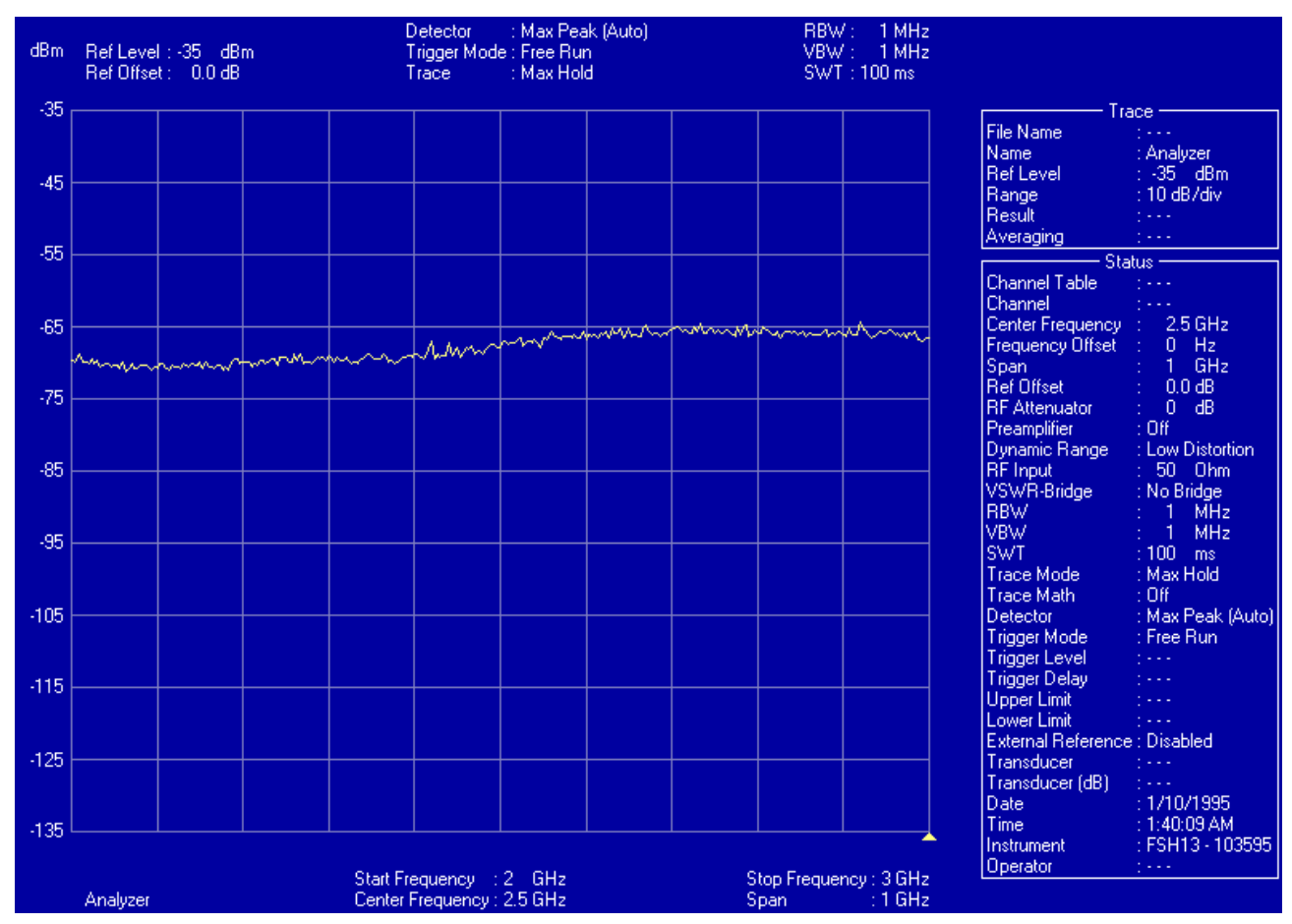

Figure 29: Spectrum centered at $2.5 \mathrm{GHz}$ and span $1 \mathrm{GHz}$ 


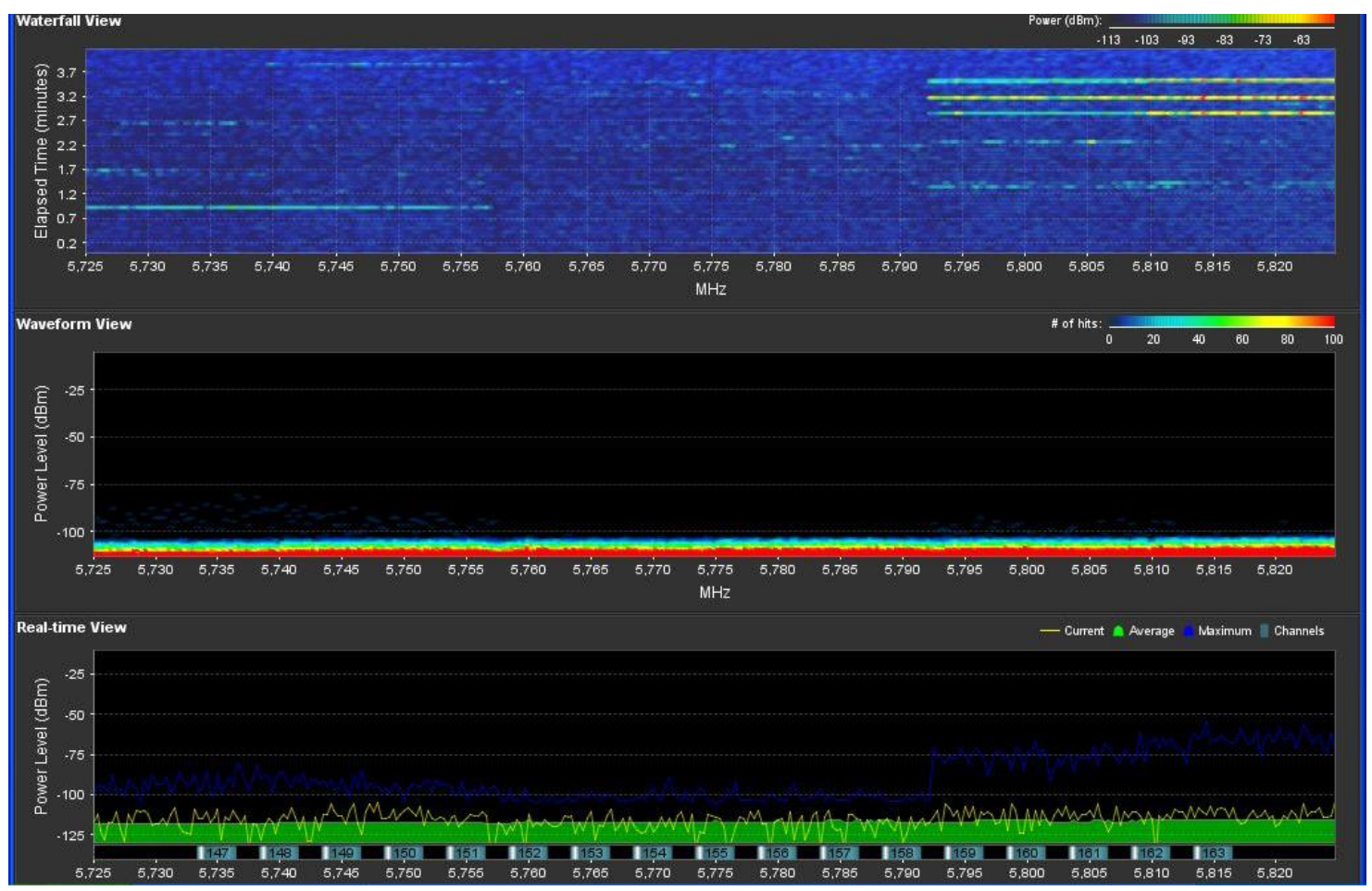

Figure 30: 5.8GHz Spectrum

\section{Location 6: Baghouse}

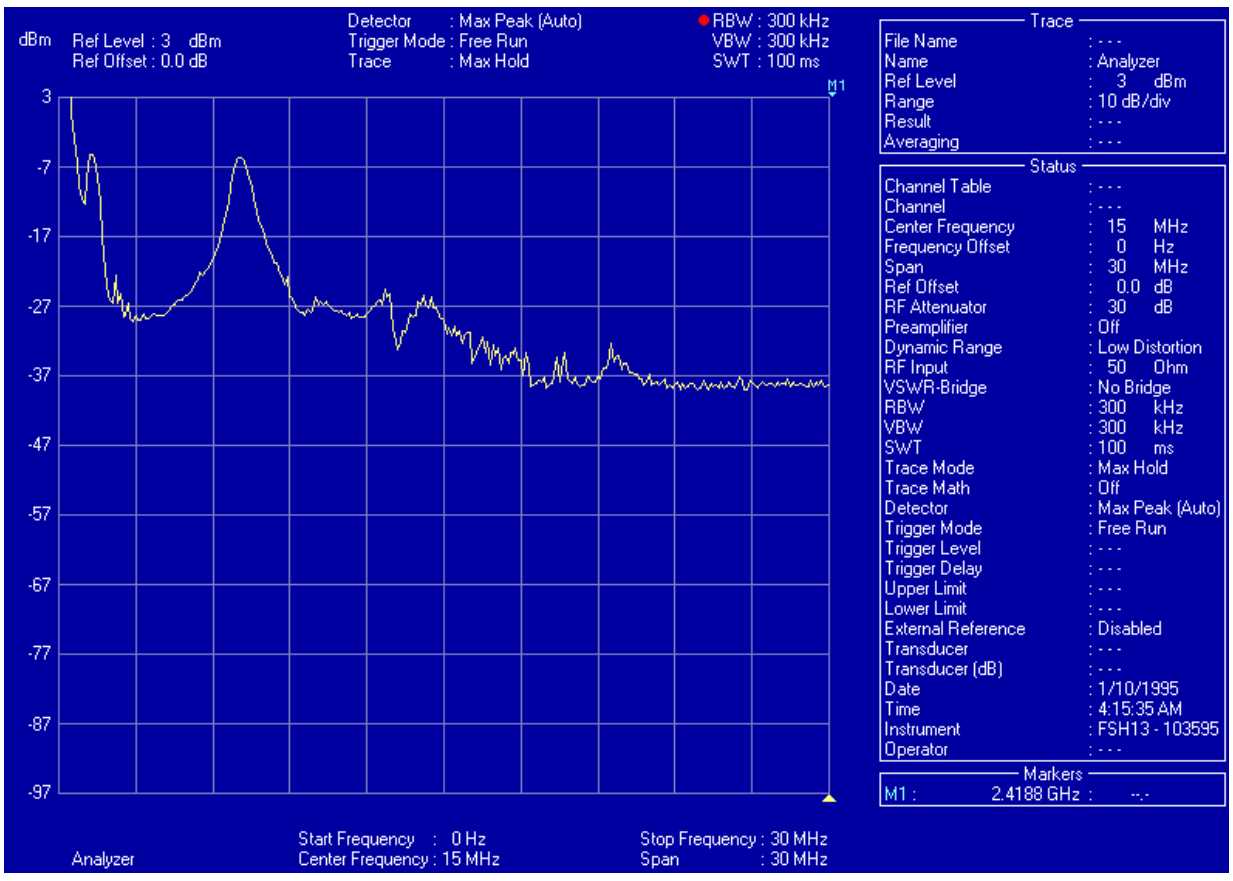

Figure 31: Spectrum centered at $15 \mathrm{MHz}$ and span $30 \mathrm{MHz}$ 


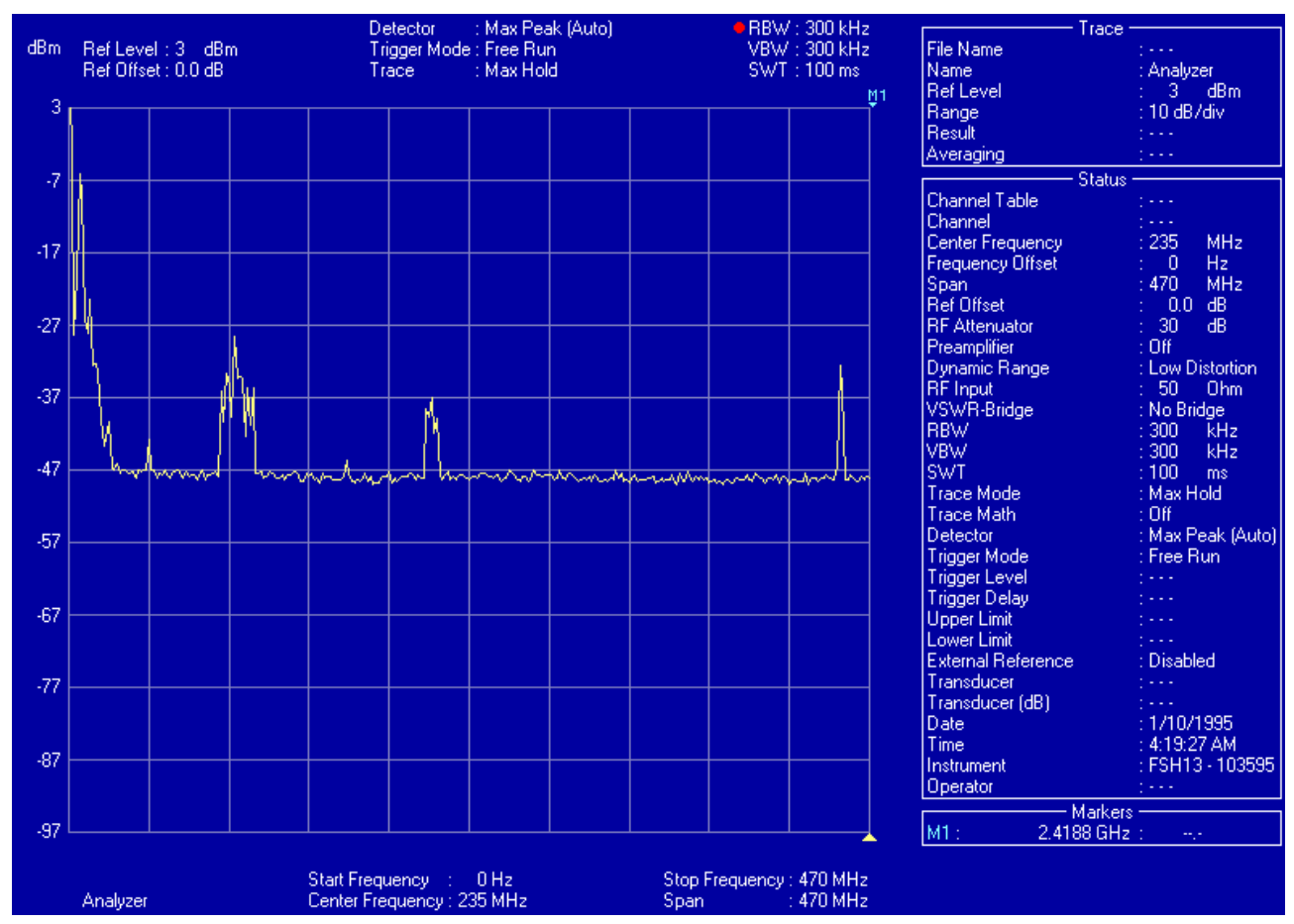

Figure 32: Spectrum centered at $235 \mathrm{MHz}$ and span $470 \mathrm{MHz}$

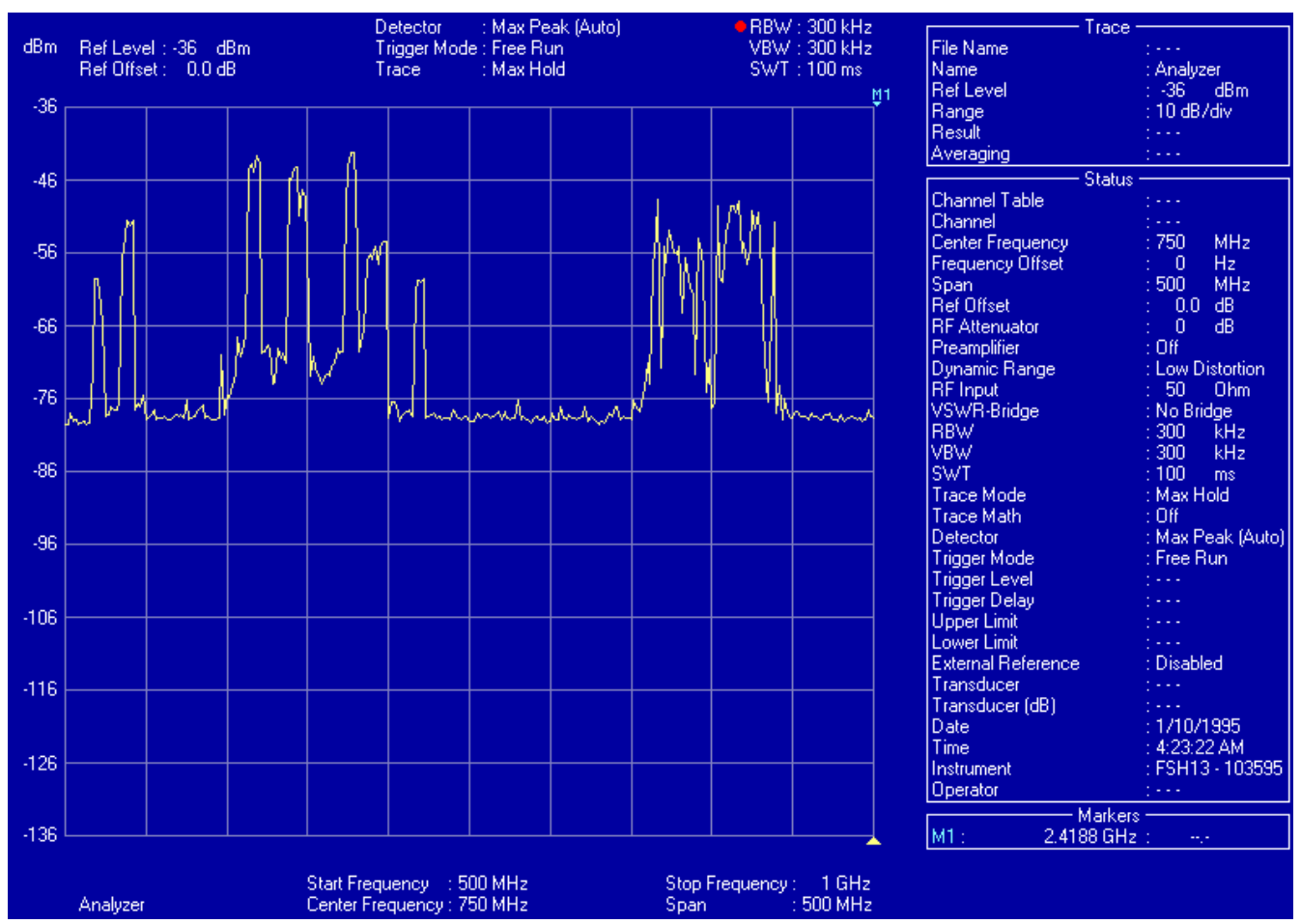

Figure 33: Spectrum centered at $750 \mathrm{MHz}$ and span $500 \mathrm{MHz}$ 


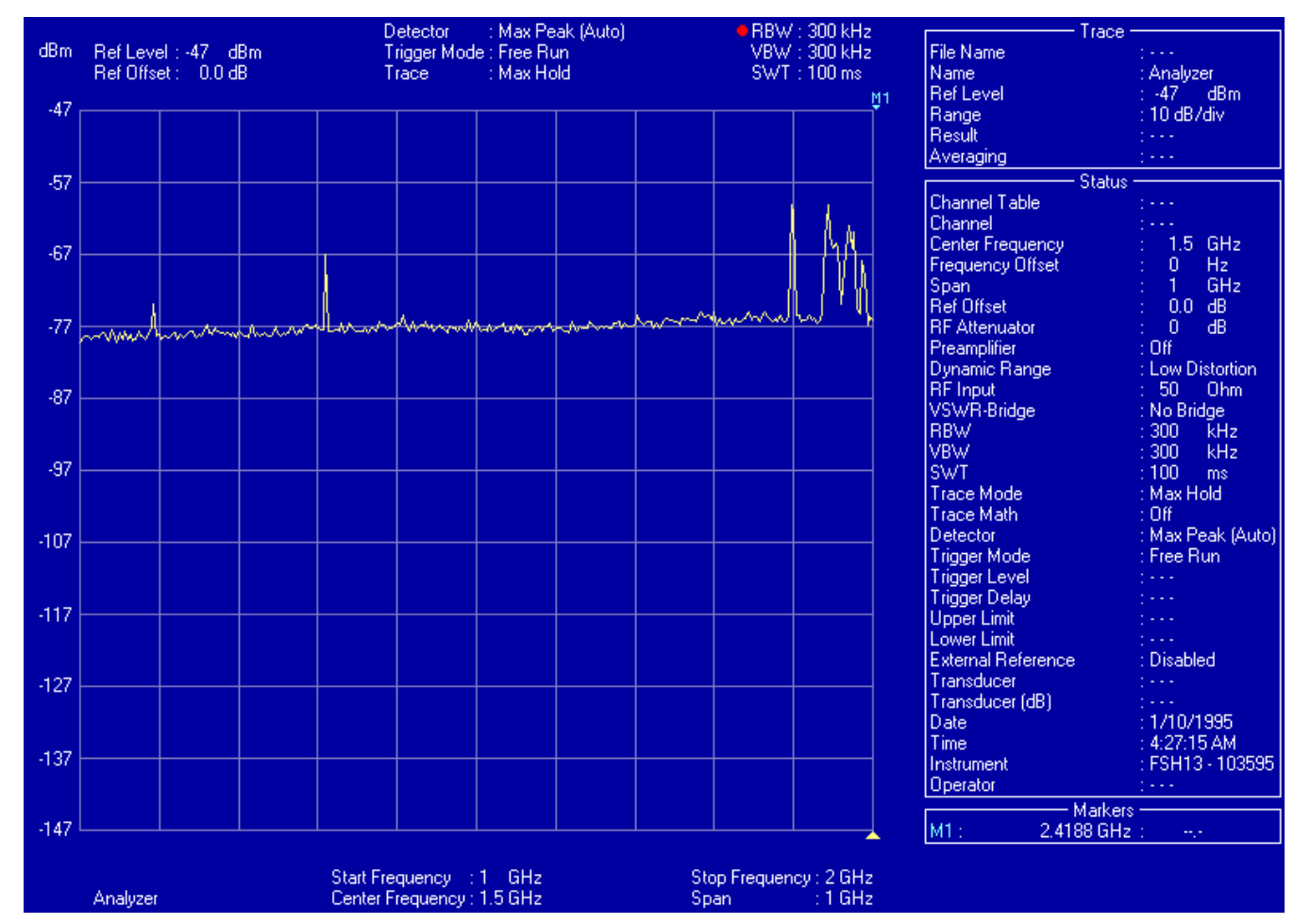

Figure 34: Spectrum centered at $1.5 \mathrm{GHz}$ and span $1 \mathrm{GHz}$

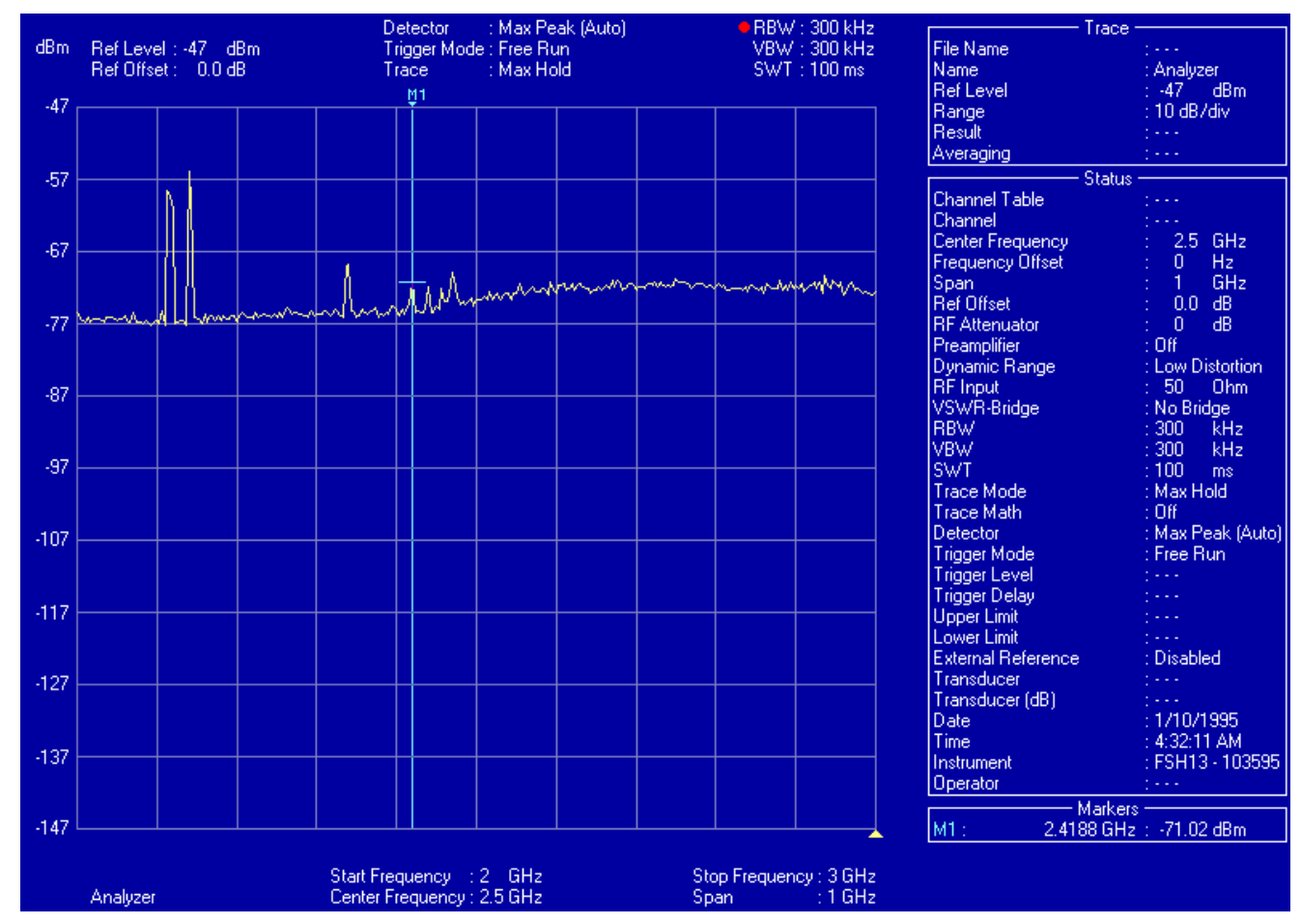

Figure 35: Spectrum centered at $2.5 \mathrm{GHz}$ and span $1 \mathrm{GHz}$ 


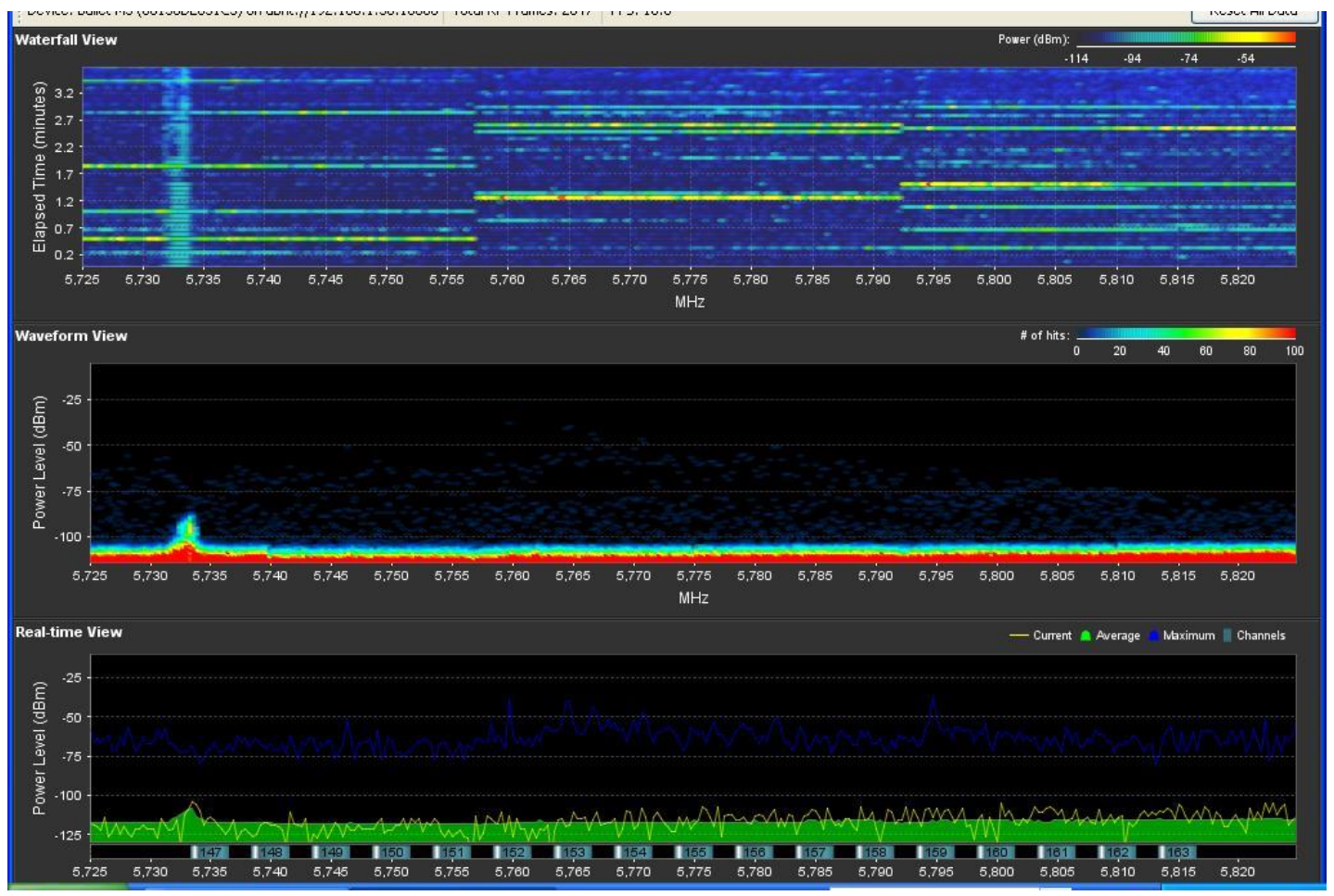

Figure 36: 5.8GHz Spectrum

\section{Location 7: Middle of Chemical Treatment Plant and Cooling Tower}

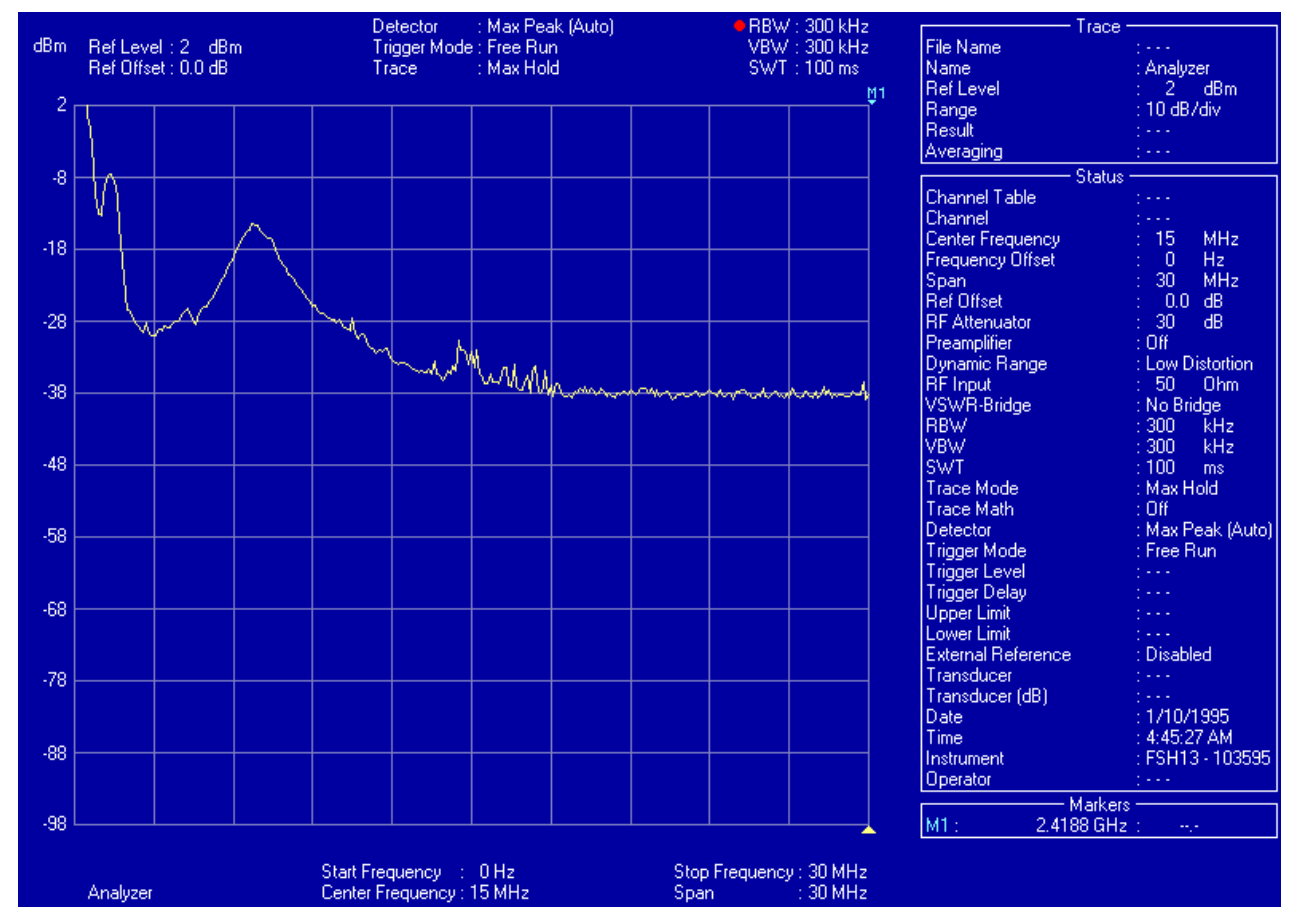

Figure 37: Spectrum centered at $15 \mathrm{MHz}$ and span $30 \mathrm{MHz}$ 


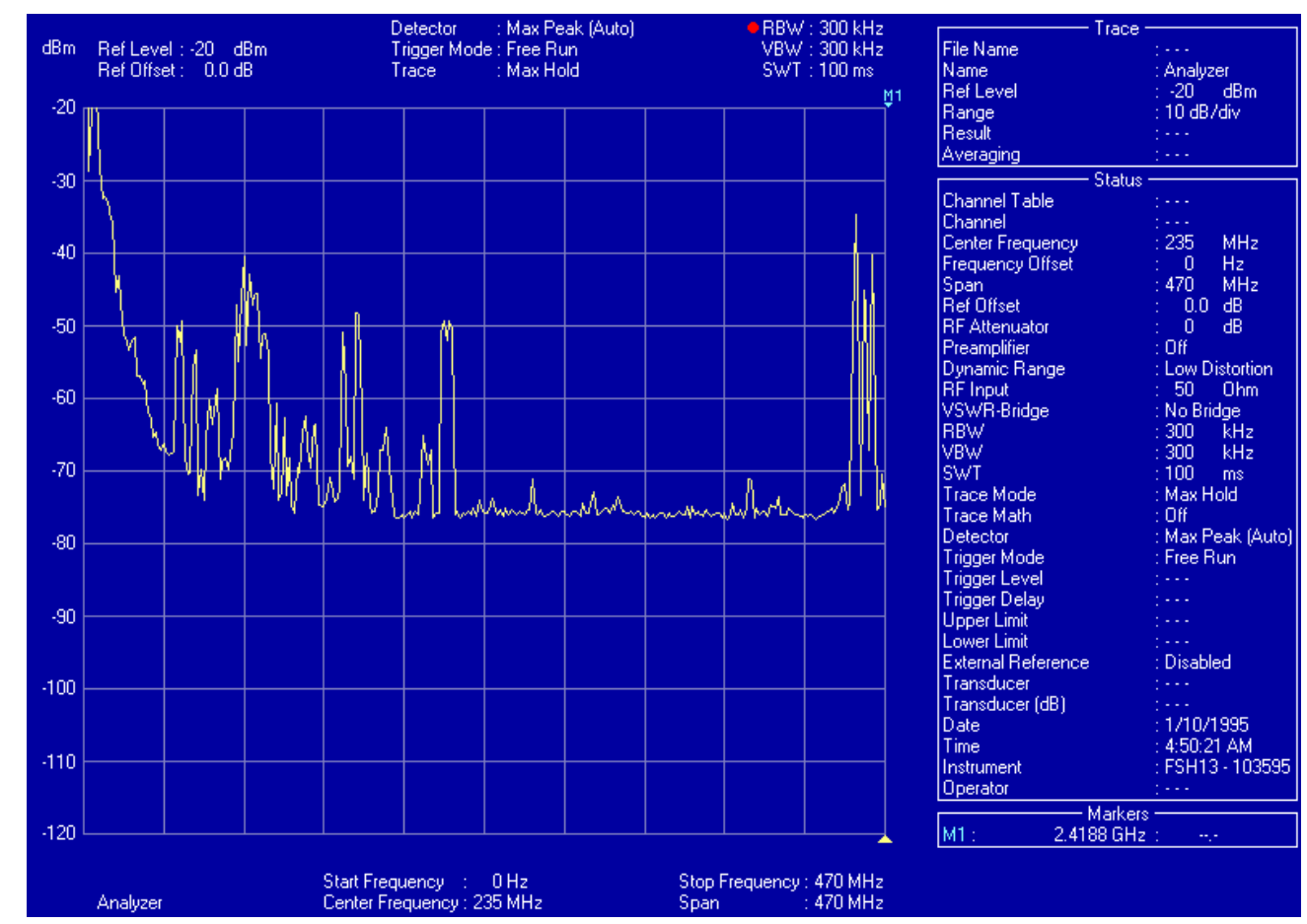

Figure 38: Spectrum centered at $235 \mathrm{MHz}$ and span $470 \mathrm{MHz}$

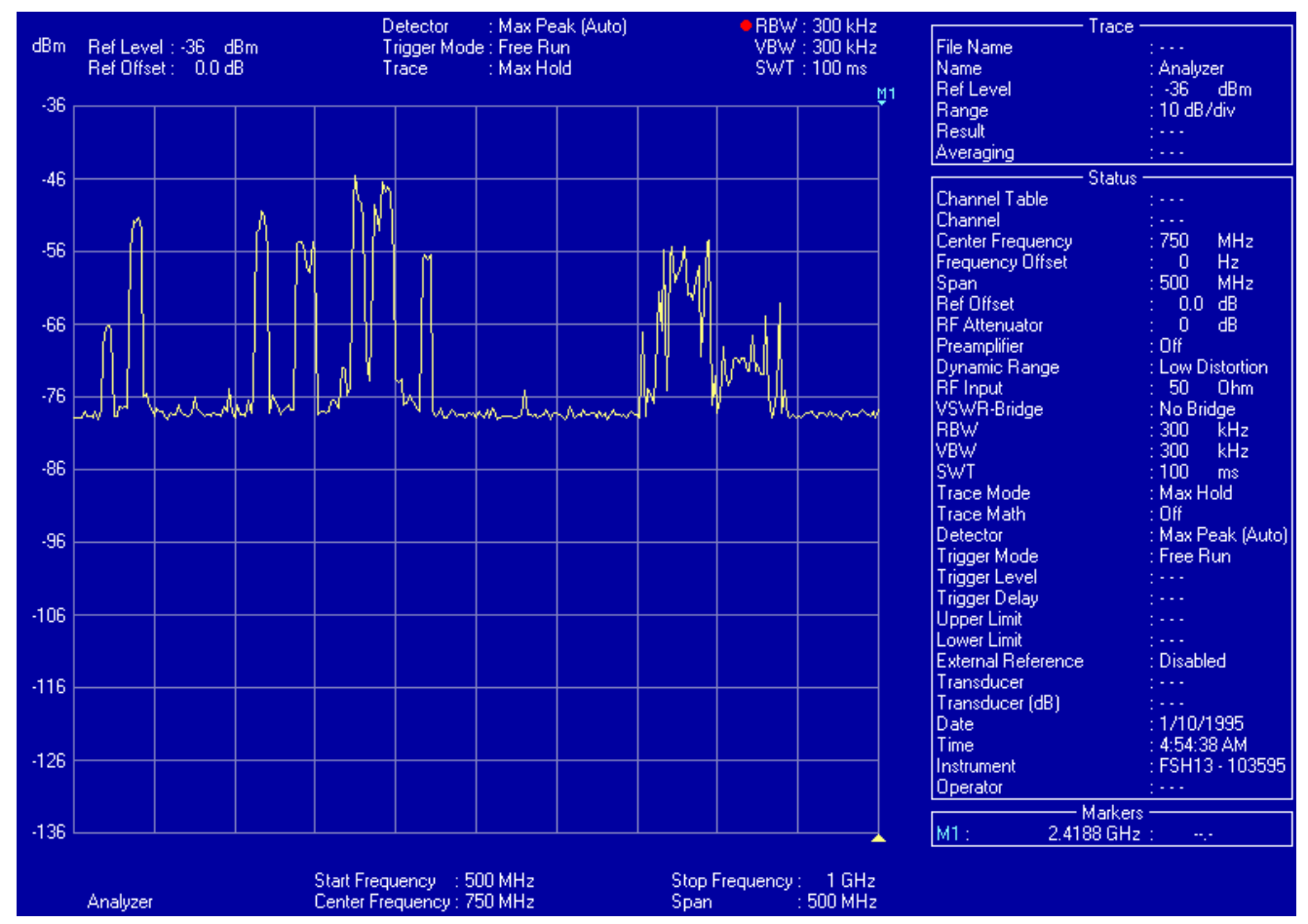

Figure 39: Spectrum centered at $750 \mathrm{MHz}$ and span $500 \mathrm{MHz}$ 


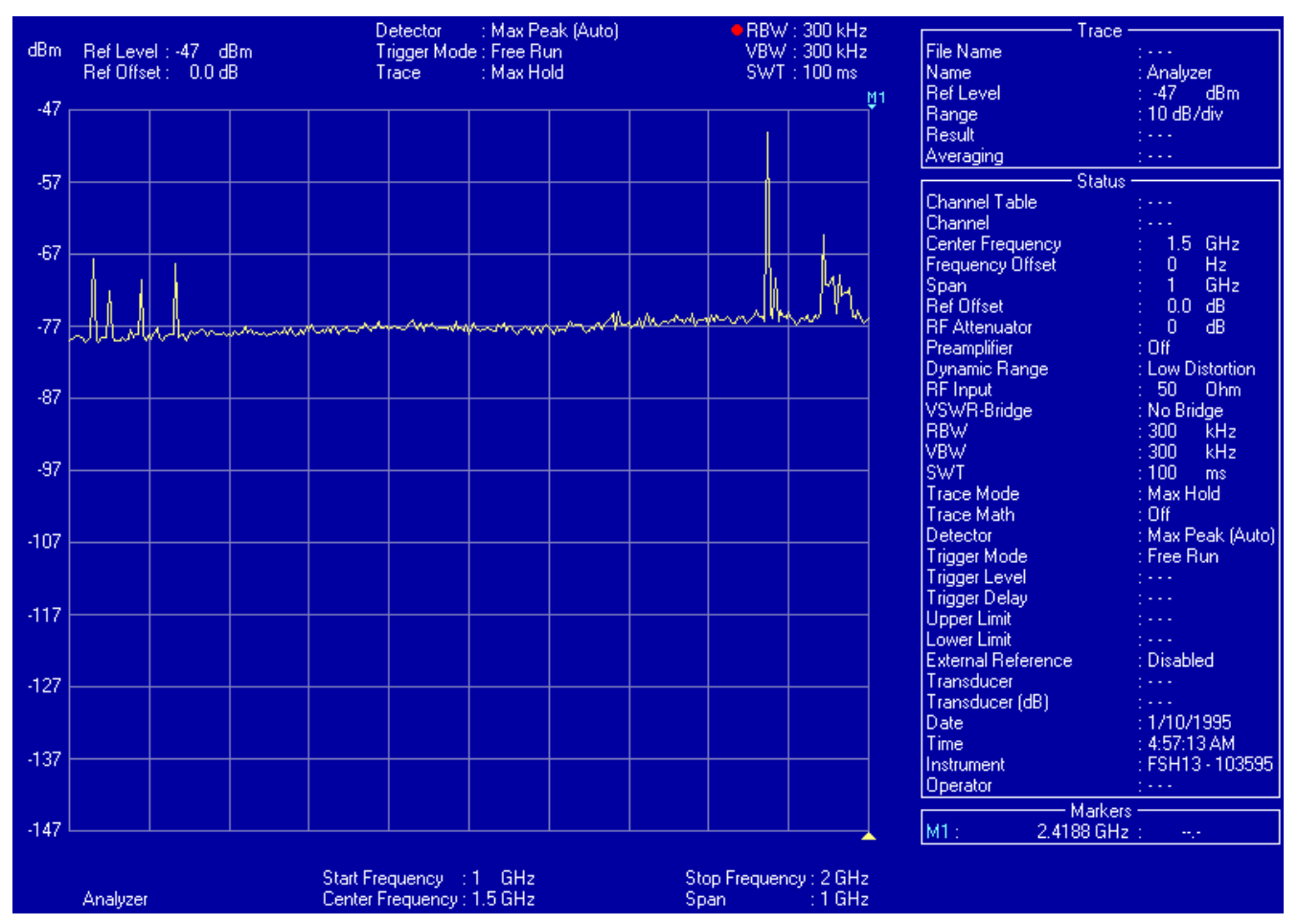

Figure 40: Spectrum centered at $1.5 \mathrm{GHz}$ and span $1 \mathrm{GHz}$

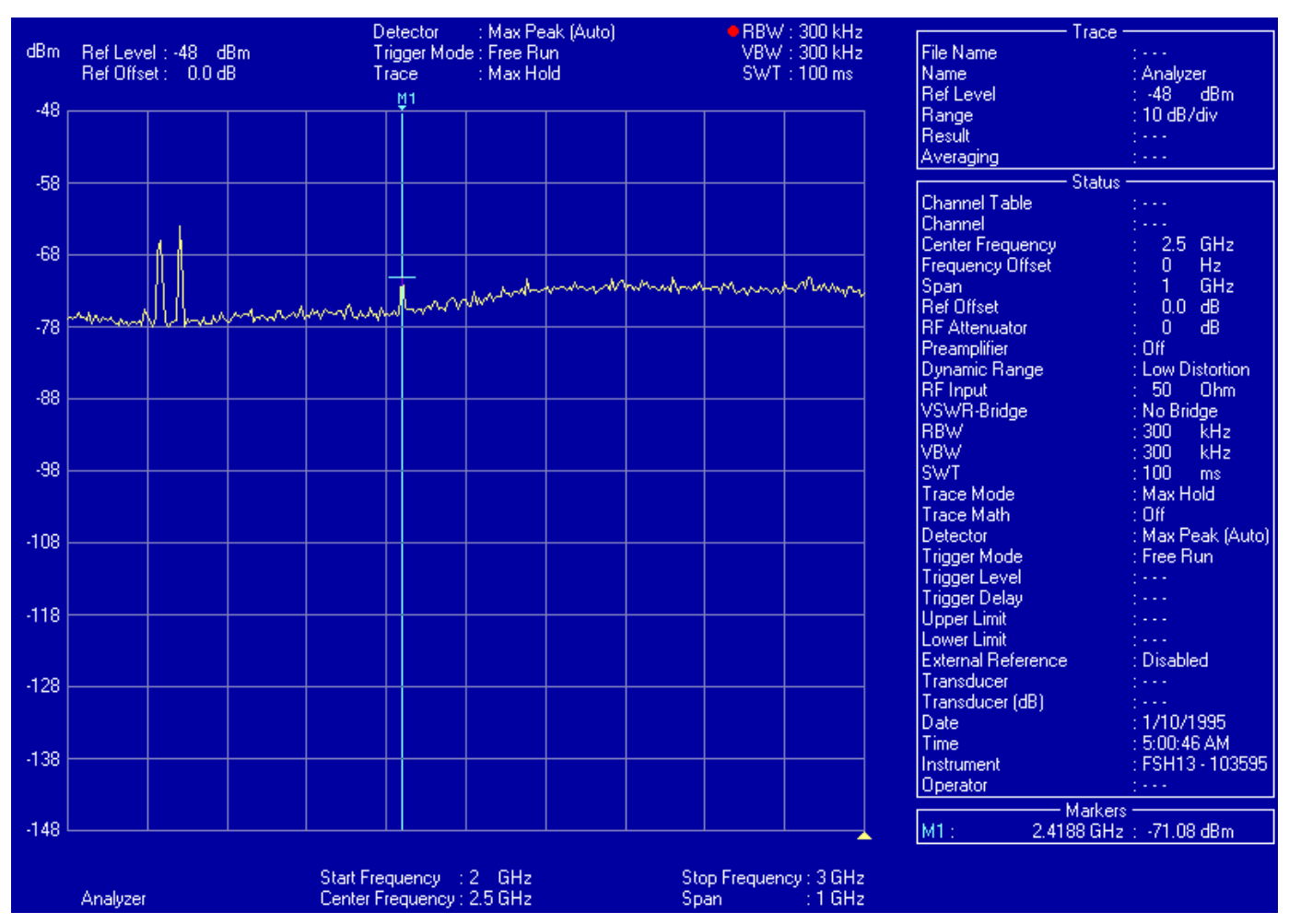

Figure 41: Spectrum centered at $2.5 \mathrm{GHz}$ and span $1 \mathrm{GHz}$ 


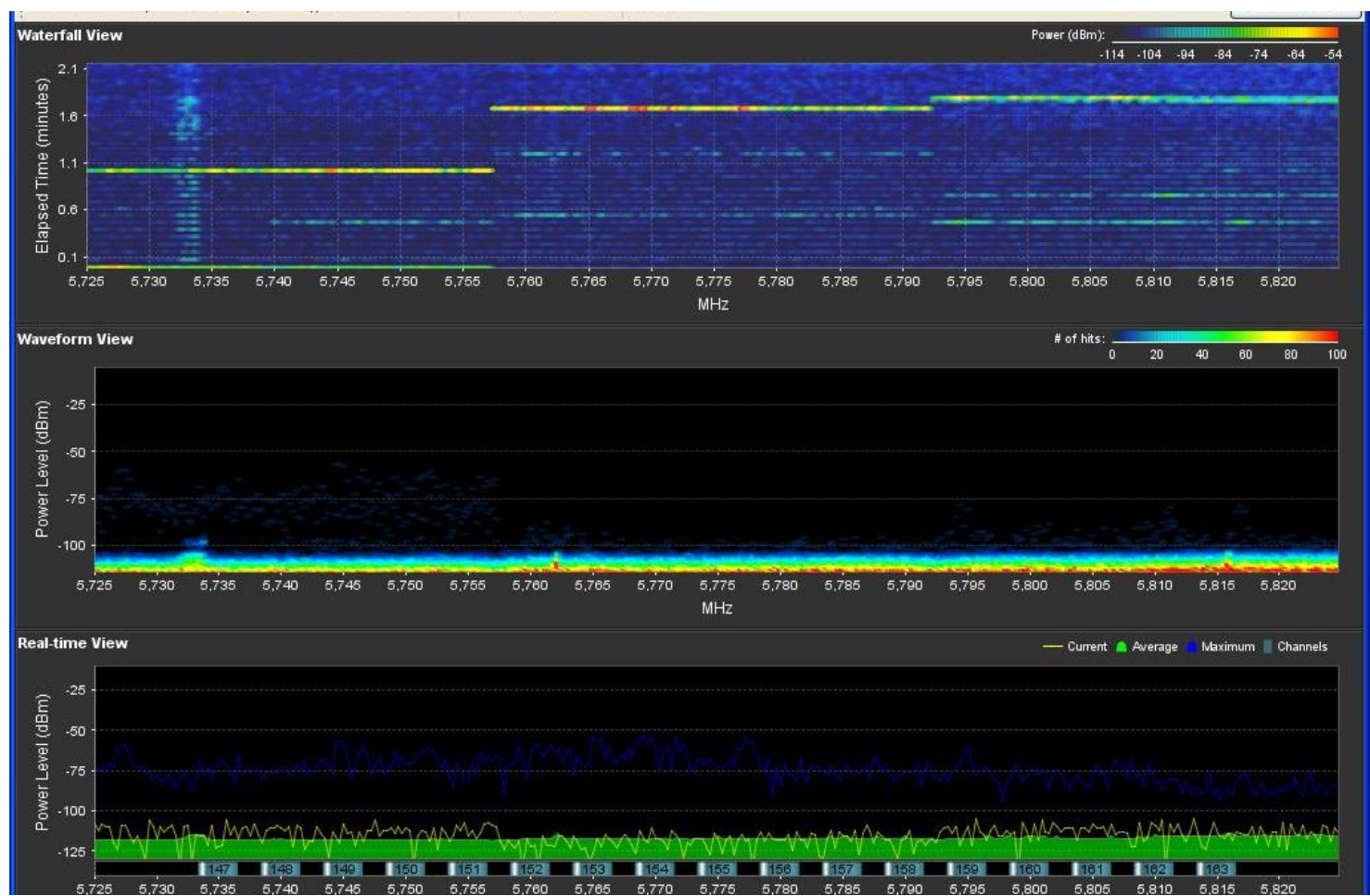

Figure 42: 5.8GHz Spectrum

\section{Location 8: Main Natural Gas Pipe Line}

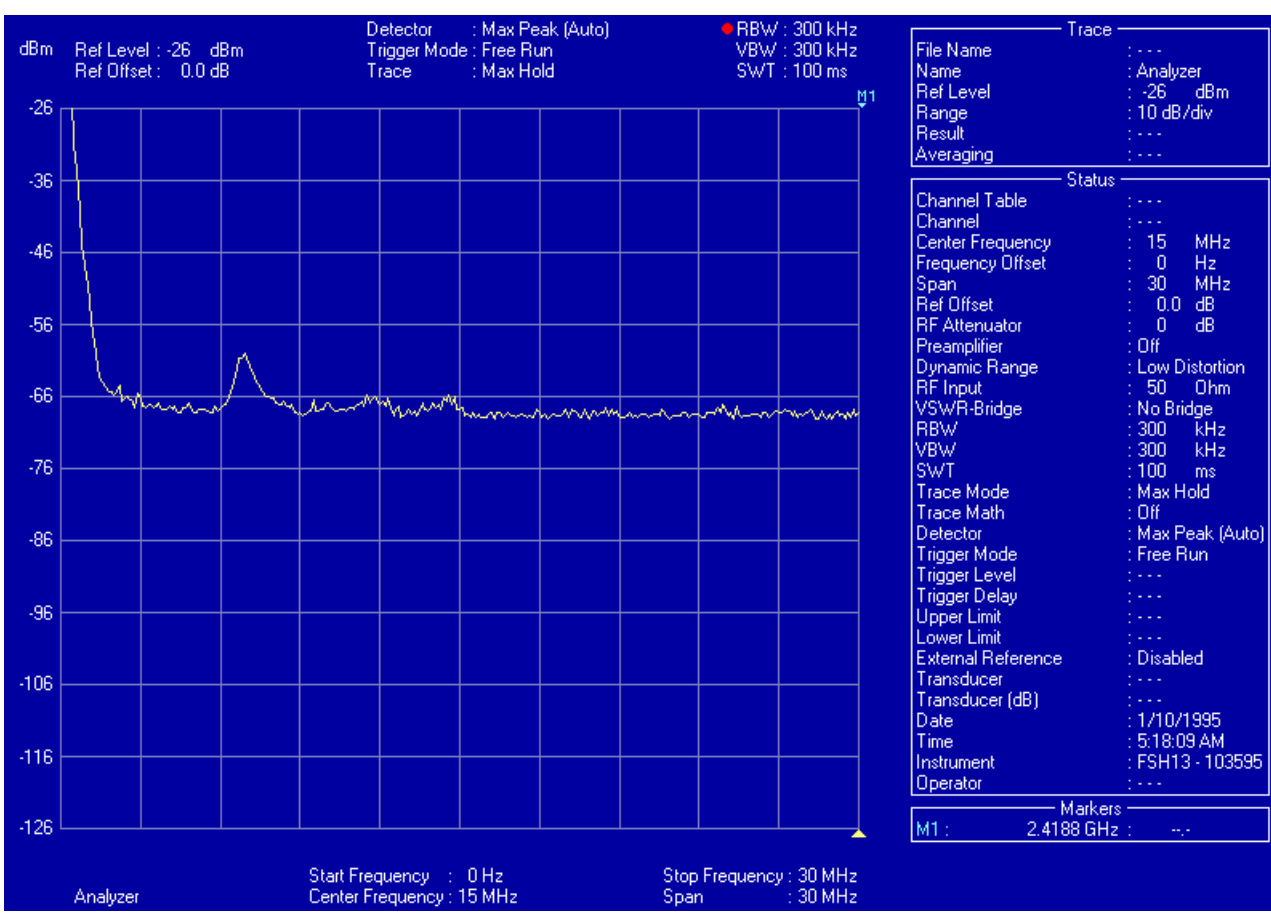

Figure 43: Spectrum centered at $15 \mathrm{MHz}$ and span $30 \mathrm{MHz}$ 


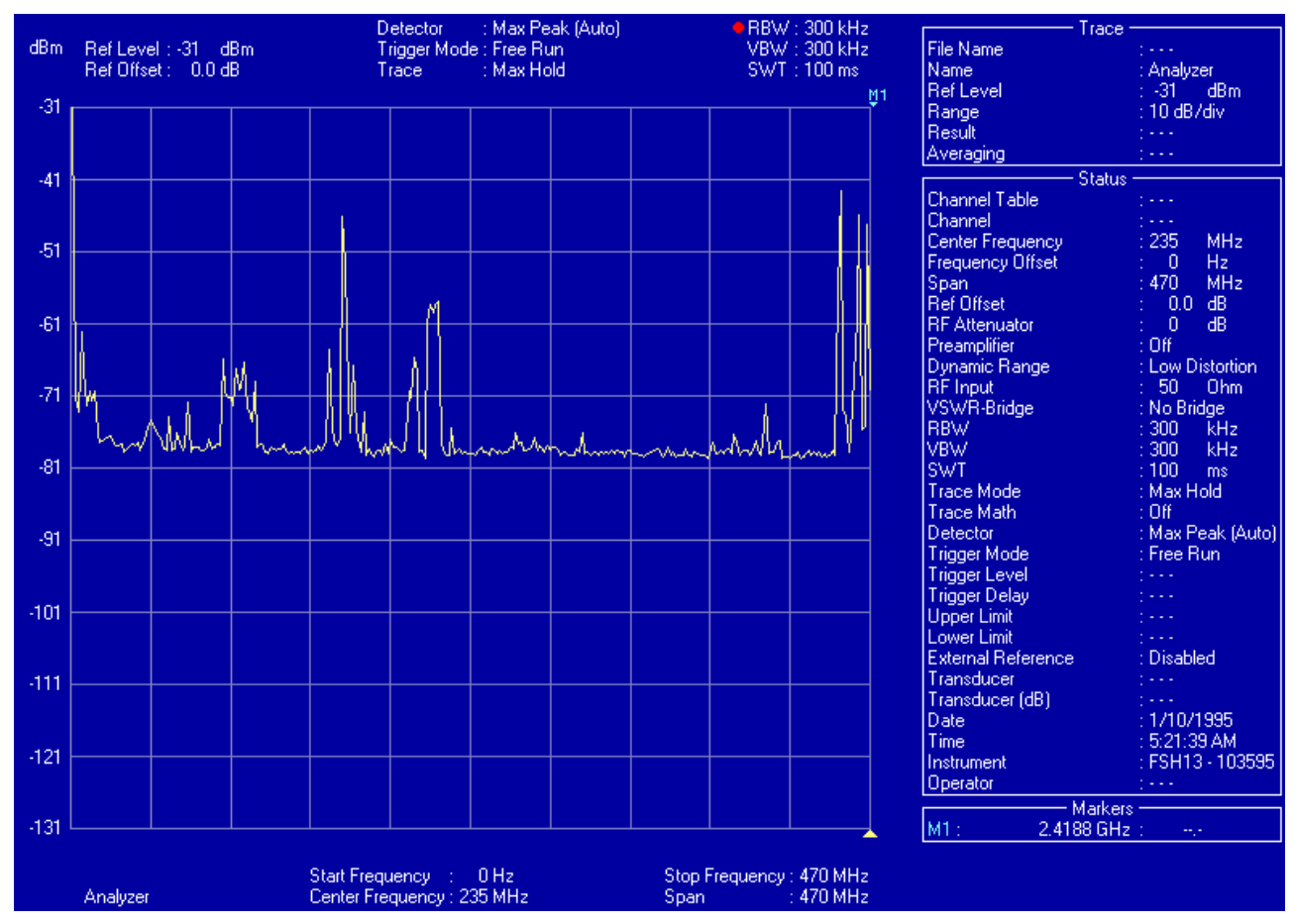

Figure 44: Spectrum centered at $235 \mathrm{MHz}$ and span $470 \mathrm{MHz}$

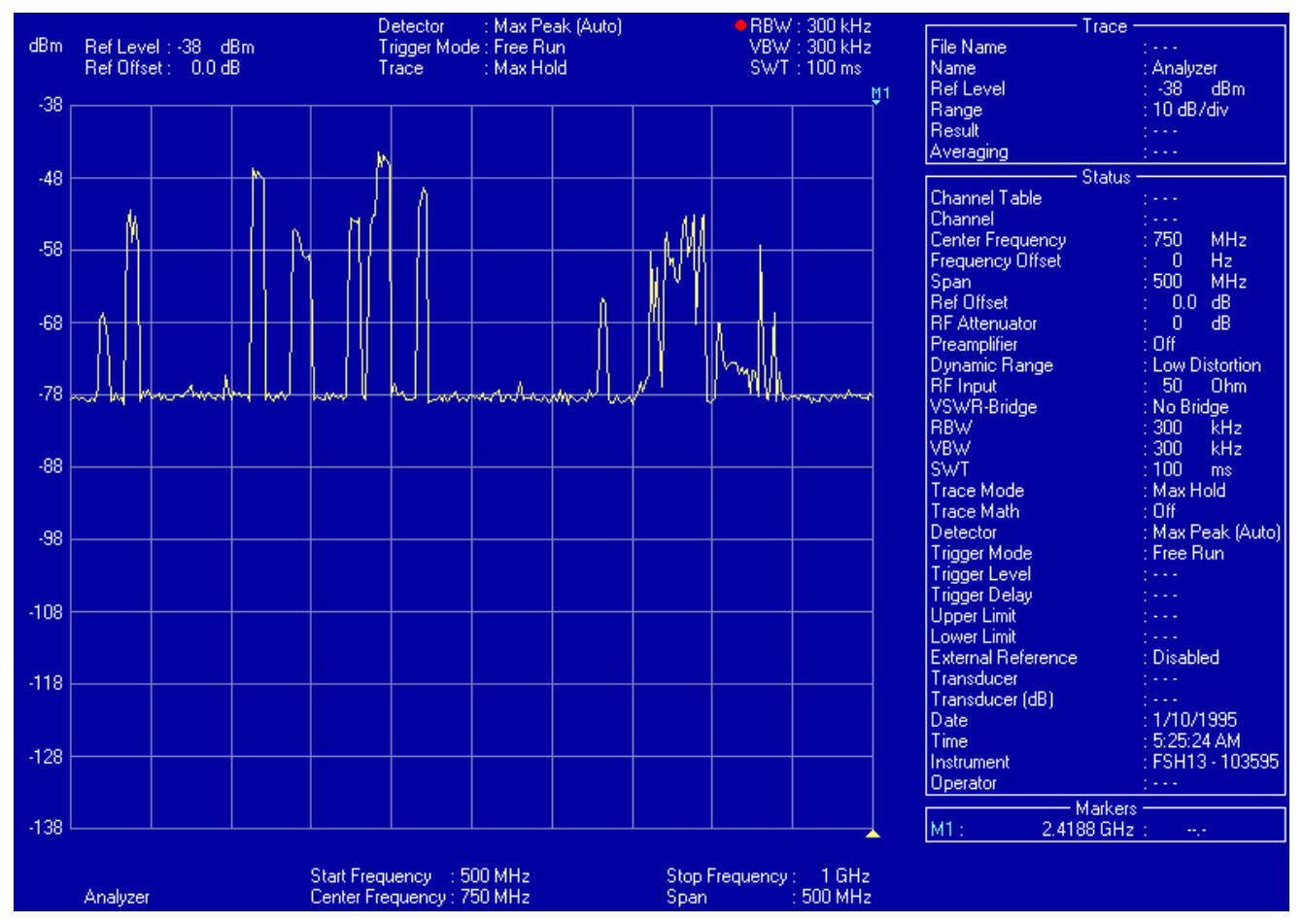

Figure 45: Spectrum centered at $750 \mathrm{MHz}$ and span $500 \mathrm{MHz}$ 


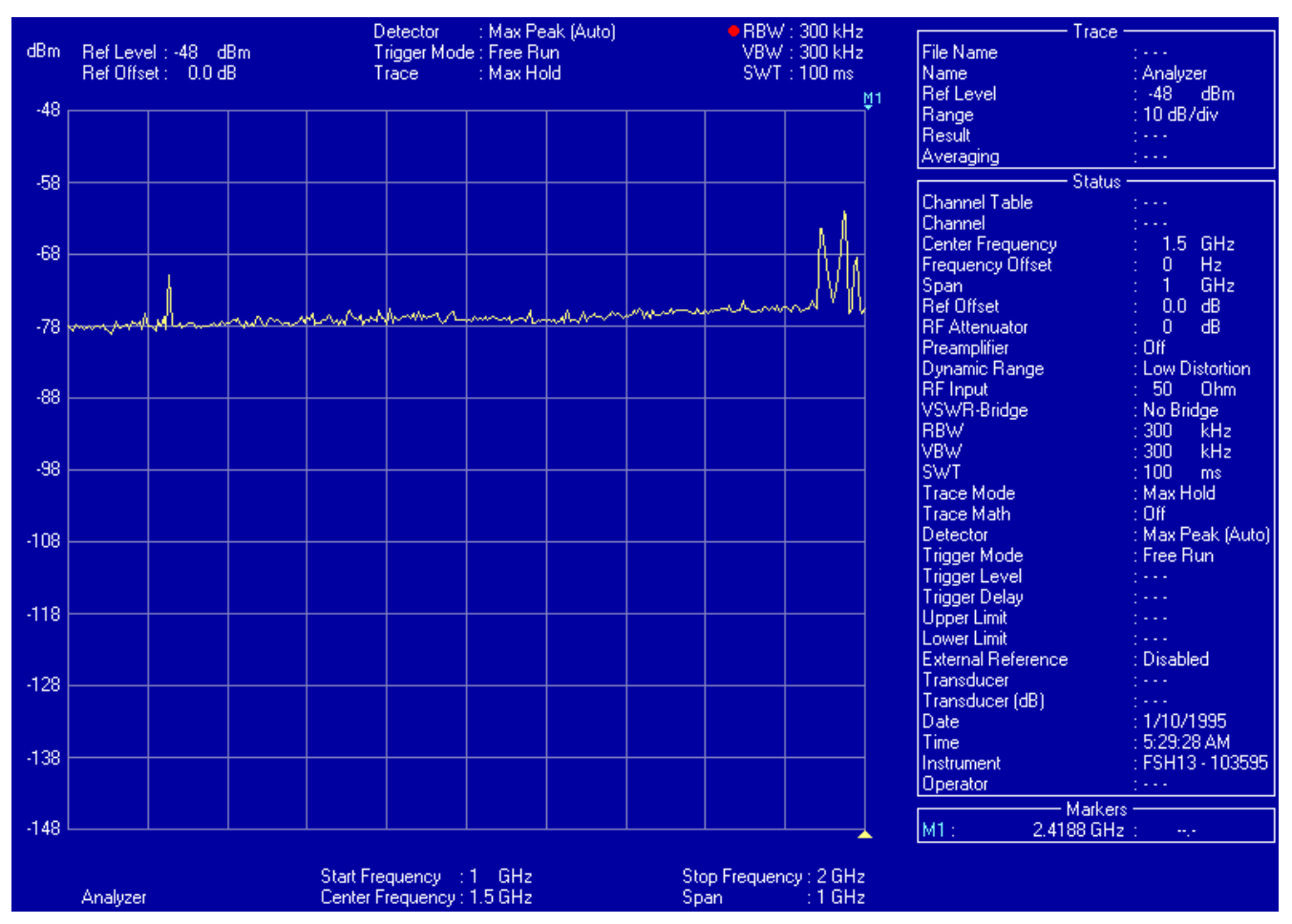

Figure 46: Spectrum centered at $1.5 \mathrm{GHz}$ and span $1 \mathrm{GHz}$

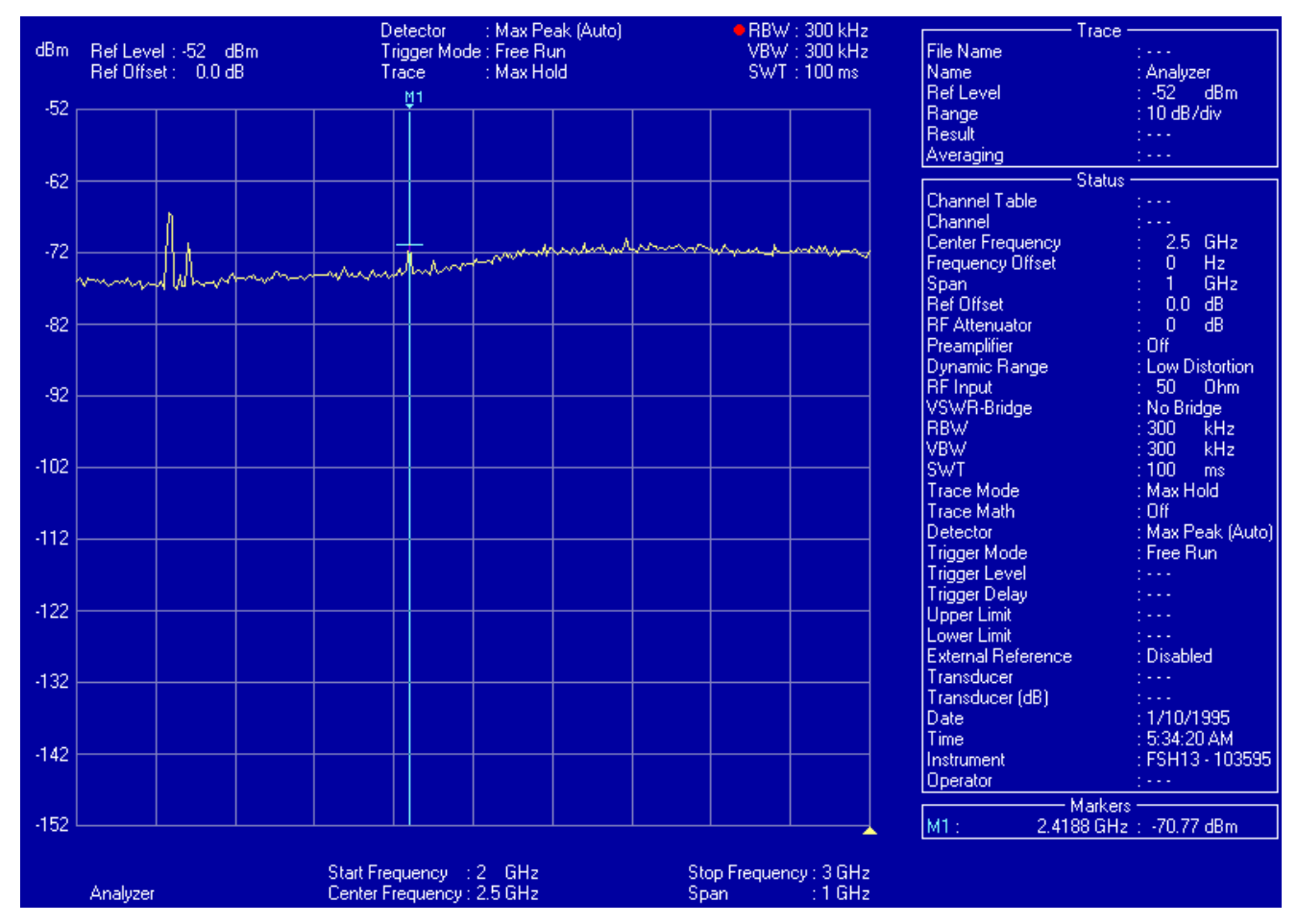

Figure 47: Spectrum centered at $2.5 \mathrm{GHz}$ and span $1 \mathrm{GHz}$ 


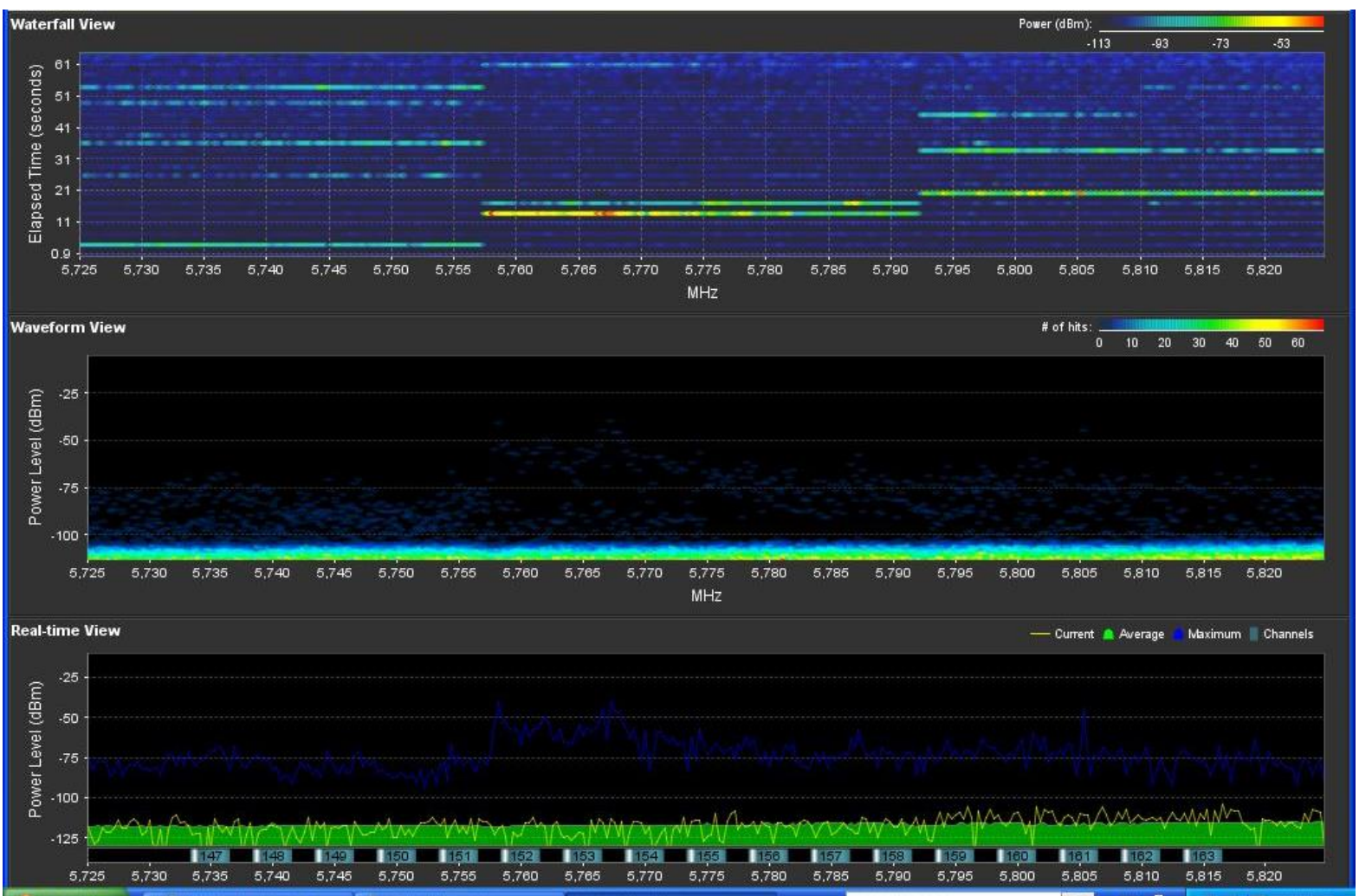

Figure 48: 5.8GHz Spectrum

\section{Antenna factor discone}

ElectroMetrics broadband antenna. To calculate the actual power spectral density values at the antenna location, the antenna factor (in units of $\mathrm{dB} \mathrm{m}^{-1}$ ) is added to the voltage (units of $\mathrm{dB}$ re $1 \mathrm{~V}$ ) at the input of the measuring instrument. The R\&S and CS65040 analyzers display amplitude as $\mathrm{dB}$ re $1 \mathrm{~mW}(\mathrm{dBm})$ referenced to their $50-\Omega$ inputs, so an additional factor of $13 \mathrm{~dB}$ must be included in to complete the field strength calculation.

$$
\mathrm{E}(\mathrm{dBV} / \mathrm{m})=\text { Reading }(\mathrm{dBm})+\mathrm{AF}\left(\mathrm{dB}^{*} \mathrm{~m}^{-1}\right)-13 \mathrm{~dB}(\mathrm{~V} / \mathrm{mW})
$$

The antenna factor as a function of frequency for the ElectroMetrics broadband antenna is shown in Fig. 49. 


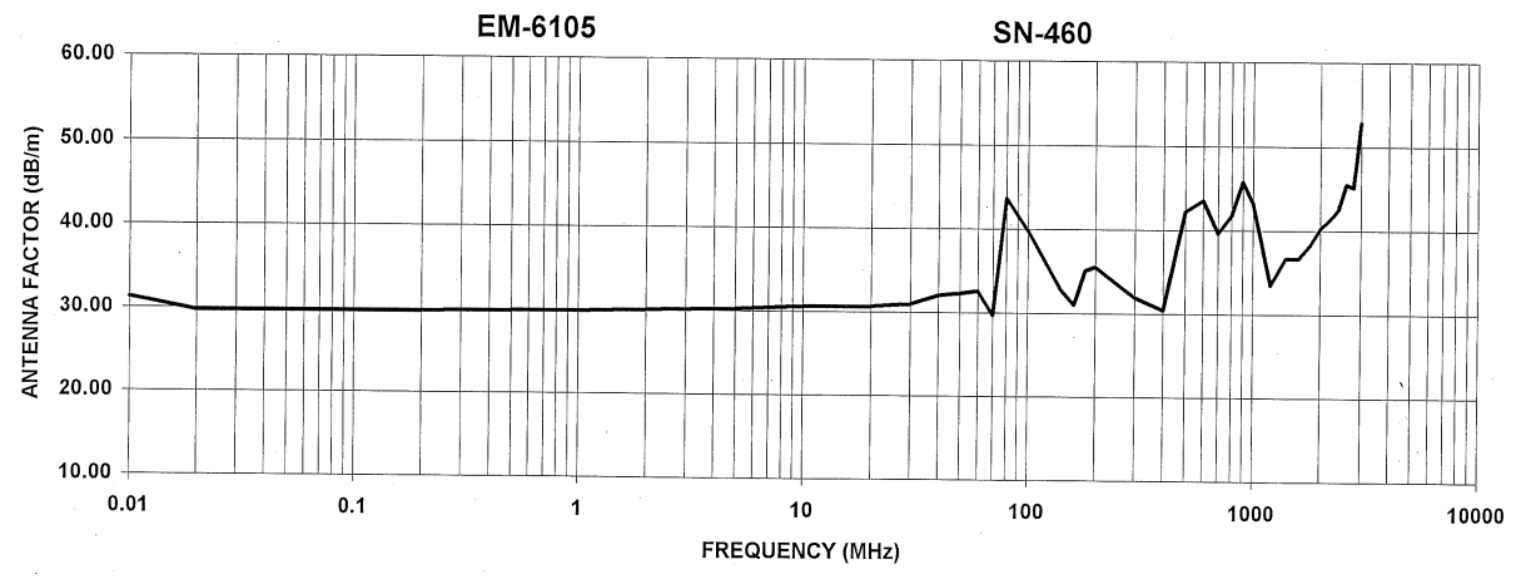

Fig. 49. Antenna factor as a function of frequency. 
Table 5. System Definition Table (Revision 1) from Appendix B of technical specification in solicitation

\begin{tabular}{|c|c|c|c|c|c|c|c|c|c|c|c|}
\hline Line & $\begin{array}{l}\text { Critic } \\
\text { ality }\end{array}$ & Process & Process Entity & $\begin{array}{l}\text { Measurement } \\
\text { Observation }\end{array}$ & Range & $\begin{array}{l}\text { Sampling } \\
\text { Rate }\end{array}$ & $\begin{array}{l}\text { Projected } \\
\text { Number of } \\
\text { Measurement } \\
\text { Points }\end{array}$ & $\begin{array}{l}\text { Current } \\
\text { or New } \\
\text { Sensor } \\
\text { (C or N) }\end{array}$ & $\begin{array}{l}\text { Environment } \\
\text { al Stressors }\end{array}$ & $\begin{array}{l}\text { Operational } \\
\text { Restrictions }\end{array}$ & Links \\
\hline 1 & \multirow[t]{10}{*}{1} & \multirow{10}{*}{$\begin{array}{l}\text { \#2 Powerhouse, } \\
\# 1, \# 2 \text { and \#3 } \\
\text { Boiler Efficiency } \\
\text { Monitoring and } \\
\text { Improvement }\end{array}$} & $\begin{array}{l}\text { Boilers in \#2 } \\
\text { Powerhouse }\end{array}$ & $\begin{array}{l}\text { Coke Oven } \\
\text { Gas Flow }\end{array}$ & $\begin{array}{l}0.0- \\
18.0 \\
\text { MMCFD } \\
\end{array}$ & $\begin{array}{l}1 \text { Second } \\
\text { Intervals }\end{array}$ & 3 & $\mathrm{C}$ & $\begin{array}{l}\text { Heat } \sim 130 \mathrm{~F} \text {, } \\
\text { Dirt. }\end{array}$ & $\begin{array}{l}\text { May be able tap off } \\
\text { current probe, if not } \\
\text { boiler must be down. }\end{array}$ & \\
\hline 2 & & & $\begin{array}{l}\text { Boilers in \#2 } \\
\text { Powerhouse }\end{array}$ & $\begin{array}{l}\text { Coke Oven } \\
\text { Gas BTU }\end{array}$ & $\begin{array}{l}300- \\
700 \text { BTU }\end{array}$ & $\begin{array}{l}30 \text { Second } \\
\text { Intervals }\end{array}$ & 3 & $\mathrm{~N}$ & $\begin{array}{l}\text { Heat } 130 \mathrm{~F} \text {, } \\
\text { Dirt. }\end{array}$ & $\begin{array}{l}\text { Boiler will need to be } \\
\text { down. }\end{array}$ & \\
\hline 3 & & & $\begin{array}{l}\text { Boilers in \#2 } \\
\text { Powerhouse }\end{array}$ & $\begin{array}{l}\text { Blast Furnace } \\
\text { Gas Flow to } \\
\text { boiler }\end{array}$ & $\begin{array}{l}0.0- \\
100.0 \\
\text { MCFM }\end{array}$ & $\begin{array}{l}1 \text { Second } \\
\text { Intervals }\end{array}$ & 3 & $\mathrm{C}$ & $\begin{array}{l}\text { Heat } \sim 130 \mathrm{~F} \text {, } \\
\text { Dirt. }\end{array}$ & $\begin{array}{l}\text { May be able tap off } \\
\text { current probe, if not } \\
\text { boiler must be down. }\end{array}$ & \\
\hline 4 & & & $\begin{array}{l}\text { Boilers in \#2 } \\
\text { Powerhouse }\end{array}$ & $\begin{array}{l}\text { Blast Furnace } \\
\text { Gas BTU }\end{array}$ & $\begin{array}{l}50-100 \\
\text { BTU }\end{array}$ & $\begin{array}{l}30 \text { Second } \\
\text { Intervals }\end{array}$ & 3 & $\mathrm{~N}$ & $\begin{array}{l}\text { Heat } \sim 130 \mathrm{~F} \text {, } \\
\text { Dirt. }\end{array}$ & $\begin{array}{l}\text { Boiler will need to be } \\
\text { down. }\end{array}$ & \\
\hline 5 & & & $\begin{array}{l}\text { Boilers in \#2 } \\
\text { Powerhouse }\end{array}$ & $\begin{array}{l}\text { Center Pilot } \\
\text { Gas Flow }\end{array}$ & $\begin{array}{l}0.0-2.0 \\
\text { MMCFD }\end{array}$ & $\begin{array}{l}1 \text { Second } \\
\text { Intervals }\end{array}$ & 3 & $\mathrm{C}$ & $\begin{array}{l}\text { Heat } \sim 130 \mathrm{~F} \text {, } \\
\text { Dirt. }\end{array}$ & $\begin{array}{l}\text { May be able tap off } \\
\text { current probe, if not } \\
\text { boiler must be down. }\end{array}$ & \\
\hline 6 & & & $\begin{array}{l}\text { Boilers in \#2 } \\
\text { Powerhouse }\end{array}$ & $\begin{array}{l}\text { Feed Water } \\
\text { Temperature }\end{array}$ & $\begin{array}{l}100.0- \\
300.0 \\
\text { DEG F }\end{array}$ & $\begin{array}{l}1 \text { Second } \\
\text { Intervals }\end{array}$ & 3 & $\mathrm{C}$ & $\begin{array}{l}\text { Heat } \sim 130 \mathrm{~F} \text {, } \\
\text { Dirt, Water }\end{array}$ & $\begin{array}{l}\text { May be able tap off } \\
\text { current probe, if not } \\
\text { boiler may need to be } \\
\text { down. }\end{array}$ & \\
\hline 7 & & & $\begin{array}{l}\text { Boilers in \#2 } \\
\text { Powerhouse }\end{array}$ & $\begin{array}{l}\text { Feedwater } \\
\text { Flow }\end{array}$ & $\begin{array}{l}0.0- \\
400.0 \\
\text { LBS/HR }\end{array}$ & $\begin{array}{l}1 \text { Second } \\
\text { Intervals }\end{array}$ & 3 & C & $\begin{array}{l}\text { Heat } \sim 130 \mathrm{~F} \text {, } \\
\text { Dirt, Water. }\end{array}$ & $\begin{array}{l}\text { May be able tap off } \\
\text { current probe, if not } \\
\text { boiler must be down. }\end{array}$ & \\
\hline 8 & & & $\begin{array}{l}\text { Boilers in \#2 } \\
\text { Powerhouse }\end{array}$ & $\begin{array}{l}\text { Economizer } \\
\text { Inlet } \\
\text { Temperature }\end{array}$ & $\begin{array}{l}100.0- \\
300.0 \\
\text { DEG F }\end{array}$ & $\begin{array}{l}5 \text { Second } \\
\text { Intervals }\end{array}$ & 1 & $\mathrm{~N}$ & $\begin{array}{l}\text { Heat } \sim 130 \mathrm{~F} \text {, } \\
\text { Dirt. }\end{array}$ & $\begin{array}{l}\text { Most likely can be } \\
\text { installed during } \\
\text { normal operation. }\end{array}$ & \\
\hline 9 & & & $\begin{array}{l}\text { Boilers in \#2 } \\
\text { Powerhouse }\end{array}$ & $\begin{array}{l}\text { Economizer } \\
\text { Outlet } \\
\text { Temperature }\end{array}$ & $\begin{array}{l}100.0- \\
500.0 \\
\text { DEG F }\end{array}$ & $\begin{array}{l}5 \text { Second } \\
\text { Intervals }\end{array}$ & 1 & $\mathrm{~N}$ & $\begin{array}{l}\text { Heat } \sim 130 \mathrm{~F} \text {, } \\
\text { Dirt. }\end{array}$ & $\begin{array}{l}\text { Most likely can be } \\
\text { installed during } \\
\text { normal operation. }\end{array}$ & \\
\hline 10 & & & $\begin{array}{l}\text { Boilers in \#2 } \\
\text { Powerhouse }\end{array}$ & $\begin{array}{l}\text { Preheater } \\
\text { Inlet } \\
\text { Temperature }\end{array}$ & $\begin{array}{l}-30- \\
300 \text { DEG } \\
F\end{array}$ & $\begin{array}{l}5 \text { Second } \\
\text { Intervals }\end{array}$ & 1 & $\mathrm{~N}$ & $\begin{array}{l}\text { Heat } \sim 130 \mathrm{~F} \text {, } \\
\text { Dirt. }\end{array}$ & $\begin{array}{l}\text { Most likely can be } \\
\text { installed during } \\
\text { normal operation. }\end{array}$ & \\
\hline
\end{tabular}




\begin{tabular}{|c|c|c|c|c|c|c|c|c|c|c|c|}
\hline Line & $\begin{array}{l}\text { Critic } \\
\text { ality }\end{array}$ & Process & Process Entity & $\begin{array}{l}\text { Measurement } \\
\text { Observation }\end{array}$ & Range & $\begin{array}{l}\text { Sampling } \\
\text { Rate }\end{array}$ & $\begin{array}{c}\text { Projected } \\
\text { Number of } \\
\text { Measurement } \\
\text { Points }\end{array}$ & $\begin{array}{l}\text { Current } \\
\text { or New } \\
\text { Sensor } \\
\text { (C or N) }\end{array}$ & $\begin{array}{c}\text { Environment } \\
\text { al Stressors }\end{array}$ & $\begin{array}{l}\text { Operational } \\
\text { Restrictions }\end{array}$ & \multirow[t]{2}{*}{ Links } \\
\hline 11 & & & $\begin{array}{l}\text { Boilers in \#2 } \\
\text { Powerhouse }\end{array}$ & $\begin{array}{l}\text { Preheater } \\
\text { Outlet } \\
\text { Temperature }\end{array}$ & $\begin{array}{l}100- \\
1000 \\
\text { DEG F }\end{array}$ & $\begin{array}{l}5 \text { Second } \\
\text { Intervals }\end{array}$ & 1 & $\mathrm{~N}$ & $\begin{array}{l}\text { Heat } \sim 130 \mathrm{~F} \text {, } \\
\text { Dirt. }\end{array}$ & $\begin{array}{l}\text { Most likely can be } \\
\text { installed during } \\
\text { normal operation. }\end{array}$ & \\
\hline 12 & & & $\begin{array}{l}\text { Boilers in \#2 } \\
\text { Powerhouse }\end{array}$ & $\begin{array}{l}\text { Combustion } \\
\text { Air Inlet Flow }\end{array}$ & $\begin{array}{l}0.0- \\
100.0 \\
\text { MCFM }\end{array}$ & $\begin{array}{l}1 \text { Second } \\
\text { Intervals }\end{array}$ & 3 & $\mathrm{~N} / \mathrm{C}$ & $\begin{array}{l}\text { Heat } \sim 130 \mathrm{~F} \text {, } \\
\text { Dirt. }\end{array}$ & $\begin{array}{l}\text { May be able tap off } \\
\text { current probe, if not } \\
\text { boiler must be down. }\end{array}$ & \\
\hline 13 & & & $\begin{array}{l}\text { Boilers in \#2 } \\
\text { Powerhouse }\end{array}$ & Steam Flow & $\begin{array}{l}0.0- \\
400.0 \\
\text { LBS/HR }\end{array}$ & $\begin{array}{l}1 \text { Second } \\
\text { Intervals }\end{array}$ & 3 & C & $\begin{array}{l}\text { Heat 130 F, } \\
\text { Dirt, Steam. }\end{array}$ & $\begin{array}{l}\text { May be able tap off } \\
\text { current probe, if not } \\
\text { boiler must be down. }\end{array}$ & \\
\hline 14 & & & $\begin{array}{l}\text { Boilers in \#2 } \\
\text { Powerhouse }\end{array}$ & $\begin{array}{l}\text { Steam } \\
\text { Temperature }\end{array}$ & $\begin{array}{l}0.0- \\
1000.0 \\
\text { DEG F }\end{array}$ & $\begin{array}{l}1 \text { Second } \\
\text { Intervals }\end{array}$ & 3 & C & $\begin{array}{l}\text { Heat } \sim 130 \mathrm{~F} \text {, } \\
\text { Dirt, Steam. }\end{array}$ & $\begin{array}{l}\text { May be able tap off } \\
\text { current probe, if not } \\
\text { boiler must be down. }\end{array}$ & \\
\hline 15 & & & $\begin{array}{l}\text { Boilers in \#2 } \\
\text { Powerhouse }\end{array}$ & $\begin{array}{l}\text { Steam } \\
\text { Pressure } \\
\text { Meter }\end{array}$ & $\begin{array}{l}0.0- \\
800.0 \\
\text { PSIG }\end{array}$ & $\begin{array}{l}1 \text { Second } \\
\text { Intervals }\end{array}$ & 3 & $\mathrm{~N}$ & $\begin{array}{l}\text { Heat } \sim 130 \mathrm{~F} \text {, } \\
\text { Dirt, Steam. }\end{array}$ & $\begin{array}{l}\text { Boiler will need to be } \\
\text { down. }\end{array}$ & \\
\hline 16 & & & Exhaust Stack & $\begin{array}{l}\text { Stack } \\
\text { Temperature }\end{array}$ & $\begin{array}{l}-30- \\
1000 \\
\text { DEGF }\end{array}$ & $\begin{array}{l}5 \text { Second } \\
\text { Intervals }\end{array}$ & 1 & $\mathrm{~N}$ & Heat, Dirt. & $\begin{array}{l}\text { Most likely can be } \\
\text { installed during } \\
\text { normal operation. }\end{array}$ & \\
\hline 17 & & & Exhaust Stack & $\begin{array}{l}\text { Stack Oxygen } \\
\text { Probe }\end{array}$ & $\begin{array}{l}0.0- \\
20.0 \% \\
\end{array}$ & $\begin{array}{l}1 \text { Second } \\
\text { Intervals }\end{array}$ & 1 & $\mathrm{~N}$ & Heat, Dirt. & $\begin{array}{l}\text { Most likely can be } \\
\text { installed during } \\
\text { normal operation. }\end{array}$ & \\
\hline 18 & & & Exhaust Stack & Stack Flow & $\begin{array}{l}0.0-3.0 \\
\text { MMCFM }\end{array}$ & $\begin{array}{l}1 \text { Second } \\
\text { Intervals }\end{array}$ & 1 & $\mathrm{~N}$ & Heat, Dirt. & $\begin{array}{l}\text { Most likely can be } \\
\text { installed during } \\
\text { normal operation. }\end{array}$ & \\
\hline 19 & 2 & $\begin{array}{l}\text { BOP Shop Air } \\
\text { Quality }\end{array}$ & $\begin{array}{l}\text { Top of BOP } \\
\text { Shop }\end{array}$ & $\begin{array}{l}\text { Opacity } \\
\text { meter in BOP } \\
\text { Shop }\end{array}$ & $\begin{array}{l}0 \text { to } \\
100 \%\end{array}$ & $\begin{array}{l}3 \text { Second } \\
\text { Intervals }\end{array}$ & 1 & $\mathrm{~N}$ & $\begin{array}{l}\text { Heat } \sim 130 \mathrm{~F} \text {, } \\
\text { Dirt. }\end{array}$ & $\begin{array}{l}\text { Can be installed } \\
\text { during normal } \\
\text { operations. }\end{array}$ & 2 BOP Shop \\
\hline 20 & 3 & $\begin{array}{l}\text { BOP Gas } \\
\text { Cleaning A \& B } \\
\text { Stack }\end{array}$ & $\begin{array}{l}\text { BOP ID Fan } \\
\text { Stacks }\end{array}$ & $\frac{\text { Opacity }}{\text { Meter }}$ & $\frac{0 \text { to }}{100 \%}$ & $\begin{array}{l}1 \text { Second } \\
\text { Intervals }\end{array}$ & 2 & $\mathrm{~N}$ & $\begin{array}{l}\text { Heat } \sim 130 \mathrm{~F} \text {, } \\
\text { Dirt, } \\
\text { weather. }\end{array}$ & $\begin{array}{l}\text { AC power available. } \\
\text { Fan can be shut down } \\
\text { one at a time to install } \\
\text { equipment. }\end{array}$ & \multirow{2}{*}{$\frac{3 \text { BOP GC }}{\underline{\text { Stacks }}}$} \\
\hline 21 & & & $\begin{array}{l}\text { BOP ID Fan } \\
\text { Stacks }\end{array}$ & Flow Meter & $\begin{array}{l}0-500 \\
\text { MCFM }\end{array}$ & $\begin{array}{l}1 \text { Second } \\
\text { Intervals }\end{array}$ & 2 & $\mathrm{~N}$ & $\begin{array}{l}\text { Heat } \sim 130 \mathrm{~F} \text {, } \\
\text { Dirt, } \\
\text { weather. }\end{array}$ & $\begin{array}{l}\text { AC power available. } \\
\text { Fan can be shut down } \\
\text { one at a time to install } \\
\text { equipment. }\end{array}$ & \\
\hline
\end{tabular}




\begin{tabular}{|c|c|c|c|c|c|c|c|c|c|c|c|}
\hline Line & $\begin{array}{l}\text { Critic } \\
\text { ality }\end{array}$ & Process & Process Entity & $\begin{array}{l}\text { Measurement } \\
\text { Observation }\end{array}$ & Range & $\begin{array}{l}\text { Sampling } \\
\text { Rate }\end{array}$ & $\begin{array}{c}\text { Projected } \\
\text { Number of } \\
\text { Measurement } \\
\text { Points }\end{array}$ & $\begin{array}{l}\text { Current } \\
\text { or New } \\
\text { Sensor } \\
\text { (C or N) }\end{array}$ & $\begin{array}{l}\text { Environment } \\
\text { al Stressors }\end{array}$ & $\begin{array}{l}\text { Operational } \\
\text { Restrictions }\end{array}$ & \multirow[t]{2}{*}{ Links } \\
\hline 22 & \multirow[t]{9}{*}{4} & \multirow[t]{9}{*}{$\begin{array}{l}\text { \#2 Power House } \\
\text { Blower } \\
\text { Efficiency }\end{array}$} & $\begin{array}{l}\text { Blowers in \#2 } \\
\text { Powerhouse }\end{array}$ & $\begin{array}{l}\text { Steam Mass } \\
\text { Flow, Actual } \\
\text { Flow }\end{array}$ & $\begin{array}{l}0- \\
300,000 \\
\text { LB/HR }\end{array}$ & $\begin{array}{l}1 \text { Second } \\
\text { Intervals }\end{array}$ & 2 & $\mathrm{C}$ & $\begin{array}{l}\text { Heat } \sim 130 ~ F, \\
\text { Dirt, Steam. }\end{array}$ & $\begin{array}{l}\text { Must work with \#2 } \\
\text { Powerhouse } \\
\text { personnel to schedule } \\
\text { installation. }\end{array}$ & \\
\hline 23 & & & $\begin{array}{l}\text { Blowers in \#2 } \\
\text { Powerhouse }\end{array}$ & $\begin{array}{l}\text { Steam } \\
\text { Temperatures }\end{array}$ & $\begin{array}{l}0-1000 \\
\text { DEG F }\end{array}$ & $\begin{array}{l}5 \text { Second } \\
\text { Intervals }\end{array}$ & 2 & $\mathrm{~N}$ & $\begin{array}{l}\text { Heat } 130 \mathrm{~F} \text {, } \\
\text { Dirt, Steam. }\end{array}$ & $\begin{array}{l}\text { Must work with \#2 } \\
\text { Powerhouse } \\
\text { personnel to schedule } \\
\text { installation. }\end{array}$ & \\
\hline 24 & & & $\begin{array}{l}\text { Blowers in \#2 } \\
\text { Powerhouse }\end{array}$ & $\begin{array}{l}\text { Steam } \\
\text { Pressure }\end{array}$ & $\begin{array}{l}0-800 \\
\text { PSIG }\end{array}$ & $\begin{array}{l}1 \text { Second } \\
\text { Intervals }\end{array}$ & 2 & $\mathrm{~N}$ & $\begin{array}{l}\text { Heat } \sim 130 \mathrm{~F} \text {, } \\
\text { Dirt, Steam. }\end{array}$ & $\begin{array}{l}\text { Must work with \#2 } \\
\text { Powerhouse } \\
\text { personnel to schedule } \\
\text { installation. }\end{array}$ & \\
\hline 25 & & & $\begin{array}{l}\text { Blowers in \#2 } \\
\text { Powerhouse }\end{array}$ & $\begin{array}{l}\text { Inlet Air Flow } \\
\text { D/P }\end{array}$ & $\begin{array}{l}0-20 \text { IN } \\
\mathrm{H} 2 \mathrm{O}\end{array}$ & $\begin{array}{l}1 \text { Second } \\
\text { Intervals }\end{array}$ & 2 & $\mathrm{C}$ & $\begin{array}{l}\text { Heat } \sim 130 \mathrm{~F} \text {, } \\
\text { Dirt. }\end{array}$ & $\begin{array}{l}\text { Must work with \#2 } \\
\text { Powerhouse } \\
\text { personnel to schedule } \\
\text { installation. }\end{array}$ & \\
\hline 26 & & & $\begin{array}{l}\text { Blowers in \#2 } \\
\text { Powerhouse }\end{array}$ & $\begin{array}{l}\text { Inlet Air } \\
\text { Pressure }\end{array}$ & $\begin{array}{l}-14.7- \\
20 \mathrm{IN} \\
\mathrm{H} 2 \mathrm{O} \\
\end{array}$ & $\begin{array}{l}1 \text { Second } \\
\text { Intervals }\end{array}$ & 2 & C & $\begin{array}{l}\text { Heat } \sim 130 \mathrm{~F} \text {, } \\
\text { Dirt. }\end{array}$ & $\begin{array}{l}\text { Must work with \#2 } \\
\text { Powerhouse } \\
\text { personnel to schedule } \\
\text { installation. }\end{array}$ & \\
\hline 27 & & & $\begin{array}{l}\text { Blowers in \#2 } \\
\text { Powerhouse }\end{array}$ & $\begin{array}{l}\text { Inlet Air } \\
\text { Temperature }\end{array}$ & $\begin{array}{l}-30- \\
200 \mathrm{DEG} \\
\mathrm{F}\end{array}$ & $\begin{array}{l}1 \text { Second } \\
\text { Intervals }\end{array}$ & 2 & C & $\begin{array}{l}\text { Heat } 130 \mathrm{~F} \text {, } \\
\text { Dirt. }\end{array}$ & $\begin{array}{l}\text { Must work with \#2 } \\
\text { Powerhouse } \\
\text { personnel to schedule } \\
\text { installation. }\end{array}$ & \\
\hline 28 & & & $\begin{array}{l}\text { Blowers in \#2 } \\
\text { Powerhouse }\end{array}$ & $\begin{array}{l}\text { Local Outlet } \\
\text { Air Flow D/P }\end{array}$ & $\begin{array}{l}0-100 \\
\text { IN H2O }\end{array}$ & $\begin{array}{l}1 \text { Second } \\
\text { Intervals }\end{array}$ & 2 & $\mathrm{~N}$ & $\begin{array}{l}\text { Heat } \sim 130 \mathrm{~F} \text {, } \\
\text { Dirt. }\end{array}$ & $\begin{array}{l}\text { Must work with \#2 } \\
\text { Powerhouse } \\
\text { personnel to schedule } \\
\text { installation. }\end{array}$ & \\
\hline 29 & & & $\begin{array}{l}\text { Blowers in \#2 } \\
\text { Powerhouse }\end{array}$ & $\begin{array}{l}\text { Local Outlet } \\
\text { Air Pressure }\end{array}$ & $\begin{array}{l}0-50 \\
\text { PSIG }\end{array}$ & $\begin{array}{l}1 \text { Second } \\
\text { Intervals }\end{array}$ & 2 & $\mathrm{~N}$ & $\begin{array}{l}\text { Heat } \sim 130 \mathrm{~F} \text {, } \\
\text { Dirt. }\end{array}$ & $\begin{array}{l}\text { Must work with \#2 } \\
\text { Powerhouse } \\
\text { personnel to schedule } \\
\text { installation. }\end{array}$ & \\
\hline 30 & & & $\begin{array}{l}\text { Blowers in \#2 } \\
\text { Powerhouse }\end{array}$ & $\begin{array}{l}\text { Local Outlet } \\
\text { Air } \\
\text { Temperature }\end{array}$ & $\begin{array}{l}0-500 \\
D E G F\end{array}$ & $\begin{array}{l}1 \text { Second } \\
\text { Intervals }\end{array}$ & 2 & $\mathrm{~N}$ & $\begin{array}{l}\text { Heat } \sim 130 \mathrm{~F} \text {, } \\
\text { Dirt. }\end{array}$ & $\begin{array}{l}\text { Must work with \#2 } \\
\text { Powerhouse } \\
\text { personnel to schedule } \\
\text { installation. }\end{array}$ & \\
\hline
\end{tabular}




\begin{tabular}{|c|c|c|c|c|c|c|c|c|c|c|c|}
\hline Line & $\begin{array}{l}\text { Critic } \\
\text { ality }\end{array}$ & Process & Process Entity & $\begin{array}{l}\text { Measurement } \\
\text { Observation }\end{array}$ & Range & $\begin{array}{l}\text { Sampling } \\
\text { Rate }\end{array}$ & $\begin{array}{l}\text { Projected } \\
\text { Number of } \\
\text { Measurement } \\
\text { Points }\end{array}$ & $\begin{array}{l}\text { Current } \\
\text { or New } \\
\text { Sensor } \\
\text { (C or } \mathrm{N})\end{array}$ & $\begin{array}{l}\text { Environment } \\
\text { al Stressors }\end{array}$ & $\begin{array}{l}\text { Operational } \\
\text { Restrictions }\end{array}$ & \multirow[t]{2}{*}{ Links } \\
\hline 31 & & & $\begin{array}{l}\text { Blowers in \#2 } \\
\text { Powerhouse }\end{array}$ & $\begin{array}{l}\text { Outlet Air } \\
\text { Flow at Blast } \\
\text { Furnace }\end{array}$ & $\begin{array}{l}0-150 \\
\text { MCFM }\end{array}$ & $\begin{array}{l}1 \text { Second } \\
\text { Intervals }\end{array}$ & 1 & C & $\begin{array}{l}\text { Heat } \sim 130 \mathrm{~F} \text {, } \\
\text { Dirt. }\end{array}$ & $\begin{array}{l}\text { Must work with \#2 } \\
\text { Powerhouse } \\
\text { personnel to schedule } \\
\text { installation. }\end{array}$ & \\
\hline 32 & \multirow[t]{2}{*}{5} & \multirow[t]{2}{*}{$\begin{array}{l}\text { Caster Torch } \\
\text { Nozzle Efficiency }\end{array}$} & Caster Torch & Oxygen Flow & $\begin{array}{l}0-10 \\
\text { CFM } \\
\end{array}$ & $\begin{array}{l}1 \text { Second } \\
\text { Intervals }\end{array}$ & 4 & $\mathrm{~N}$ & $\begin{array}{l}\text { Heat } \sim 130 \mathrm{~F} \text {, } \\
\text { Dirt. }\end{array}$ & $\begin{array}{l}\text { AC Power available. } \\
\text { Must be installed on } \\
\text { downturn. }\end{array}$ & \\
\hline 33 & & & Caster Torch & Gas Flow & $\begin{array}{l}0-10 \\
\text { CFM }\end{array}$ & $\begin{array}{l}1 \text { Second } \\
\text { Intervals }\end{array}$ & 4 & $\mathrm{~N}$ & $\begin{array}{l}\text { Heat } \sim 130 \mathrm{~F} \text {, } \\
\text { Dirt. }\end{array}$ & $\begin{array}{l}\text { AC Power available. } \\
\text { Must be installed on } \\
\text { downturn. }\end{array}$ & \\
\hline 34 & \multirow[t]{2}{*}{6} & \multirow[t]{2}{*}{$\begin{array}{l}\text { Individual } \\
\text { Metering for the } \\
\text { Seven BOP } \\
\text { Preheaters }\end{array}$} & At Preheater & $\begin{array}{l}\text { Natural Gas } \\
\text { Flow }\end{array}$ & $\begin{array}{l}0-300 \\
\text { SCFM }\end{array}$ & $\begin{array}{l}3 \text { Second } \\
\text { Intervals }\end{array}$ & 1 & $\mathrm{~N}$ & $\begin{array}{l}\text { Heat } \sim 130 \mathrm{~F} \text {, } \\
\text { Dirt. }\end{array}$ & $\begin{array}{l}\text { AC Power Available. } \\
\text { Preheater can be shut } \\
\text { down during normal } \\
\text { operation to install } \\
\text { equipment. }\end{array}$ & $\frac{\frac{6 \text { BOP }}{\text { Preheater }}}{\text { Natural Gas }}$ \\
\hline 35 & & & At Preheater & $\begin{array}{l}\text { Coke Gas } \\
\text { Flow }\end{array}$ & $\begin{array}{l}0-500 \\
\text { SCFM }\end{array}$ & $\begin{array}{l}3 \text { Second } \\
\text { Intervals }\end{array}$ & 6 & $\mathrm{~N}$ & $\begin{array}{l}\text { Heat } \sim 130 \mathrm{~F} \text {, } \\
\text { Dirt. }\end{array}$ & $\begin{array}{l}\text { AC Power Available. } \\
\text { Preheaters can be } \\
\text { shut down one at a } \\
\text { time during normal } \\
\text { operation to install } \\
\text { equipment. }\end{array}$ & $\begin{array}{l}\frac{6 \text { Coke Gas }}{\underline{B O P}} \\
\underline{\text { Preheaters }}\end{array}$ \\
\hline 36 & \multirow[t]{3}{*}{7} & \multirow{3}{*}{$\begin{array}{l}\text { Compressor } \\
\text { Loading } \\
\text { Distribution } \\
\text { Efficiency } \\
\text { focusing on } \\
\text { Caster Air Mist } \\
\text { and Instrument } \\
\text { Air Compressors }\end{array}$} & $\begin{array}{l}\text { All } \\
\text { Compressors }\end{array}$ & $\begin{array}{l}\text { Air Flow from } \\
\text { each } \\
\text { compressor }\end{array}$ & $\begin{array}{l}0-6000 \\
\text { SCFM } \\
\text { AIR } \\
\text { MIST 0 - } \\
2500 \\
\text { OTHERS }\end{array}$ & $\begin{array}{l}3 \text { Second } \\
\text { Intervals }\end{array}$ & 3 & $\mathrm{~N}$ & $\begin{array}{l}\text { Heat } \sim 130 \mathrm{~F} \text {, } \\
\text { Dirt. }\end{array}$ & $\begin{array}{l}\text { AC Power available. } \\
\text { Compressors can be } \\
\text { shut down one at a } \\
\text { time during normal } \\
\text { operations to install } \\
\text { equipment. }\end{array}$ & $\begin{array}{c}\underline{7} \\
\text { Compressors } \\
\end{array}$ \\
\hline 37 & & & $\begin{array}{l}\text { All } \\
\text { Compressors }\end{array}$ & $\begin{array}{l}\text { Pressure from } \\
\text { each } \\
\text { compressor }\end{array}$ & $\begin{array}{l}0-150 \\
\text { PSIG }\end{array}$ & $\begin{array}{l}3 \text { Second } \\
\text { Intervals }\end{array}$ & 3 & $\mathrm{~N}$ & $\begin{array}{l}\text { Heat } \sim 130 \mathrm{~F} \text {, } \\
\text { Dirt. }\end{array}$ & $\begin{array}{l}\text { AC Power available. } \\
\text { Compressors can be } \\
\text { shut down one at a } \\
\text { time during normal } \\
\text { operations to install } \\
\text { equipment. }\end{array}$ & $\begin{array}{c}\underline{7} \\
\text { Compressors }\end{array}$ \\
\hline 38 & & & $\begin{array}{l}\text { various } \\
\text { locations }\end{array}$ & $\begin{array}{l}\text { Pressure from } \\
\text { various points } \\
\text { in the plant }\end{array}$ & $\begin{array}{l}0-150 \\
\text { PSIG }\end{array}$ & $\begin{array}{l}3 \text { Second } \\
\text { Intervals }\end{array}$ & & $\mathrm{C} / \mathrm{N}$ & $\begin{array}{l}\text { Heat } \sim 130 \mathrm{~F} \text {, } \\
\text { Dirt, } \\
\text { weather. }\end{array}$ & $\begin{array}{l}\text { Some locations lack } \\
\text { plug in power. }\end{array}$ & $\begin{array}{c}\underline{7} \\
\text { Compressors }\end{array}$ \\
\hline
\end{tabular}




\begin{tabular}{|c|c|c|c|c|c|c|c|c|c|c|c|}
\hline Line & $\begin{array}{l}\text { Critic } \\
\text { ality }\end{array}$ & Process & Process Entity & $\begin{array}{l}\text { Measurement } \\
\text { Observation }\end{array}$ & Range & $\begin{array}{l}\text { Sampling } \\
\text { Rate }\end{array}$ & $\begin{array}{l}\text { Projected } \\
\text { Number of } \\
\text { Measurement } \\
\text { Points }\end{array}$ & $\begin{array}{l}\text { Current } \\
\text { or New } \\
\text { Sensor } \\
\text { (C or } N)\end{array}$ & $\begin{array}{l}\text { Environment } \\
\text { al Stressors }\end{array}$ & $\begin{array}{l}\text { Operational } \\
\text { Restrictions }\end{array}$ & Links \\
\hline 39 & & & $\begin{array}{l}\text { various } \\
\text { locations }\end{array}$ & $\begin{array}{l}\text { Flow from } \\
\text { various points } \\
\text { in the plant } \\
\end{array}$ & $\begin{array}{l}0-3000 \\
\text { SCFM }\end{array}$ & $\begin{array}{l}3 \text { Second } \\
\text { Intervals }\end{array}$ & & $\mathrm{C} / \mathrm{N}$ & $\begin{array}{l}\text { Heat } 130 \mathrm{~F} \text {, } \\
\text { Dirt, } \\
\text { weather. }\end{array}$ & $\begin{array}{l}\text { Some locations lack } \\
\text { plug in power. }\end{array}$ & $\begin{array}{c}\underline{7} \\
\text { Compressors }\end{array}$ \\
\hline 40 & $\frac{8}{9}$ & $\begin{array}{l}\text { Nitrogen Main } \\
\text { Gas Line }\end{array}$ & $\begin{array}{l}\text { Main Nitrogen } \\
\text { Lines }\end{array}$ & $\begin{array}{l}\text { High Pressure } \\
\text { Flow Meters }\end{array}$ & $\begin{array}{l}0-3000 \\
\text { SCFM }\end{array}$ & $\begin{array}{l}3 \text { Second } \\
\text { Intervals }\end{array}$ & 2 & $\mathrm{~N}$ & $\begin{array}{l}\text { Heat } 130 \mathrm{~F} \text {, } \\
\text { Dirt, } \\
\text { weather. }\end{array}$ & $\begin{array}{l}\text { AC power not } \\
\text { available. Must be } \\
\text { done during } \\
\text { downturn. }\end{array}$ & $\frac{8 \text { Nitrogen }}{\underline{\text { Line }}}$ \\
\hline \multirow[t]{2}{*}{41} & \multirow[t]{2}{*}{9} & \multirow[t]{2}{*}{$\begin{array}{l}\text { Natural Gas } \\
\text { Usage }\end{array}$} & $\begin{array}{l}\text { Main Natural } \\
\text { Gas Line }\end{array}$ & $\begin{array}{l}\text { Main Line } \\
\text { Flow }\end{array}$ & $\begin{array}{l}0-40 \\
\text { MMCFD }\end{array}$ & $\begin{array}{l}3 \text { Second } \\
\text { Intervals }\end{array}$ & 2 & $\mathrm{C}$ & $\begin{array}{l}\text { Heat } 130 \mathrm{~F} \text {, } \\
\text { Dirt, } \\
\text { weather. }\end{array}$ & $\begin{array}{l}\text { Must be done during } \\
\text { outage. }\end{array}$ & \\
\hline & & & $\begin{array}{l}\text { Various } \\
\text { locations }\end{array}$ & $\begin{array}{l}\text { Individual } \\
\text { Consumer } \\
\text { Flows }\end{array}$ & $\begin{array}{l}0-5 \\
\text { MMCFD }\end{array}$ & $\begin{array}{l}3 \text { Second } \\
\text { Intervals }\end{array}$ & & $\mathrm{N}$ & $\begin{array}{l}\text { Heat } 130 \mathrm{~F} \text {, } \\
\text { Dirt, } \\
\text { weather. }\end{array}$ & $\begin{array}{l}\text { Some locations lack } \\
\text { plug in power. }\end{array}$ & \\
\hline 43 & \multirow[t]{4}{*}{10} & \multirow[t]{4}{*}{$\begin{array}{l}\text { BOP Gas } \\
\text { Cleaning A\&B ID } \\
\text { Fan Motors and } \\
\text { Fan Efficiency }\end{array}$} & $\begin{array}{l}\text { BOP ID Fan } \\
\text { Motor }\end{array}$ & $\begin{array}{l}\text { Motor } \\
\text { Current }\end{array}$ & $\begin{array}{l}0-800 \\
\text { Amp }\end{array}$ & $\begin{array}{l}5 \text { Second } \\
\text { Intervals }\end{array}$ & 6 & C & $\begin{array}{l}\text { Heat } 130 \mathrm{~F} \text {, } \\
\text { Dirt, } \\
\text { weather. }\end{array}$ & $\begin{array}{l}\text { AC power available. } \\
\text { Fans can be shut } \\
\text { down one at a time } \\
\text { during normal } \\
\text { operation to install } \\
\text { equipment. }\end{array}$ & \multirow{4}{*}{$\frac{10 \text { BOP GC ID }}{\underline{\text { Fan }}}$} \\
\hline 44 & & & $\begin{array}{l}\text { BOP ID Fan } \\
\text { Motor }\end{array}$ & Motor RPM & $\begin{array}{l}0-1400 \\
\text { RPM }\end{array}$ & $\begin{array}{l}5 \text { Second } \\
\text { Intervals }\end{array}$ & 2 & $\mathrm{~N}$ & $\begin{array}{l}\text { Heat } 130 \mathrm{~F} \text {, } \\
\text { Dirt, } \\
\text { weather. }\end{array}$ & $\begin{array}{l}\text { AC power available. } \\
\text { Fans can be shut } \\
\text { down one at a time } \\
\text { during normal } \\
\text { operation to install } \\
\text { equipment. }\end{array}$ & \\
\hline 45 & & & $\begin{array}{l}\text { BOP ID Fan } \\
\text { Motor }\end{array}$ & $\begin{array}{l}\text { Stator } \\
\text { Temperature }\end{array}$ & $200 \mathrm{C}$ & $\begin{array}{l}5 \text { Second } \\
\text { Intervals }\end{array}$ & 6 & C & $\begin{array}{l}\text { Heat } 130 \mathrm{~F} \text {, } \\
\text { Dirt, } \\
\text { weather. }\end{array}$ & $\begin{array}{l}\text { AC power available. } \\
\text { Fans can be shut } \\
\text { down one at a time } \\
\text { during normal } \\
\text { operation to install } \\
\text { equipment. }\end{array}$ & \\
\hline 46 & & & BOP ID Fan & Fan RPM & $\begin{array}{l}0-1400 \\
\text { RPM }\end{array}$ & $\begin{array}{l}1 \text { Second } \\
\text { Intervals }\end{array}$ & 2 & $\mathrm{~N}$ & $\begin{array}{l}\text { Heat } 130 \mathrm{~F} \text {, } \\
\text { Dirt, } \\
\text { weather. }\end{array}$ & $\begin{array}{l}\text { AC power available. } \\
\text { Fans can be shut } \\
\text { down one at a time } \\
\text { during normal } \\
\text { operation to install }\end{array}$ & \\
\hline
\end{tabular}




\begin{tabular}{|c|c|c|c|c|c|c|c|c|c|c|c|}
\hline Line & $\begin{array}{l}\text { Critic } \\
\text { ality }\end{array}$ & Process & Process Entity & $\begin{array}{c}\text { Measurement } \\
\text { Observation }\end{array}$ & Range & $\begin{array}{l}\text { Sampling } \\
\text { Rate }\end{array}$ & $\begin{array}{c}\text { Projected } \\
\text { Number of } \\
\text { Measurement } \\
\text { Points }\end{array}$ & $\begin{array}{l}\text { Current } \\
\text { or New } \\
\text { Sensor } \\
\text { (C or N) }\end{array}$ & $\begin{array}{c}\text { Environment } \\
\text { al Stressors }\end{array}$ & $\begin{array}{l}\text { Operational } \\
\text { Restrictions }\end{array}$ & \multirow[t]{2}{*}{ Links } \\
\hline & & & & & & & & & & equipment. & \\
\hline 47 & \multirow[t]{3}{*}{11} & \multirow[t]{3}{*}{$\begin{array}{l}\text { BOP "F" and "R" } \\
\text { Duct Flow }\end{array}$} & $\begin{array}{l}\text { Duct work for } \\
\text { "R" and "F" } \\
\text { Furnace. }\end{array}$ & Air Flow & $\begin{array}{l}0-500 \\
\text { MCFM }\end{array}$ & $\begin{array}{l}1 \text { Second } \\
\text { Intervals }\end{array}$ & 2 & $\mathrm{~N}$ & & $\begin{array}{l}\text { Ac power available. } \\
\text { Depending on how } \\
\text { long it takes to install } \\
\text { equipment, it may be } \\
\text { possible to arrange } \\
\text { production schedule } \\
\text { to install equipment. }\end{array}$ & \multirow{3}{*}{$\frac{11 \text { BOP F\&R }}{\underline{\text { Duct }}}$} \\
\hline 48 & & & $\begin{array}{l}\text { Duct work for } \\
\text { "R" and "F" } \\
\text { Furnace. }\end{array}$ & Air Pressure & $\begin{array}{l}0.0- \\
800.0 \\
\text { PSIG }\end{array}$ & $\begin{array}{l}1 \text { Second } \\
\text { Intervals }\end{array}$ & 2 & $\mathrm{~N}$ & & $\begin{array}{l}\text { Ac power available. } \\
\text { Depending on how } \\
\text { long it takes to install } \\
\text { equipment, it may be } \\
\text { possible to arrange } \\
\text { production schedule } \\
\text { to install equipment. }\end{array}$ & \\
\hline 49 & & & $\begin{array}{l}\text { Duct work for } \\
\text { "R" and "F" } \\
\text { Furnace. }\end{array}$ & $\begin{array}{l}\text { Air } \\
\text { Temperature }\end{array}$ & $\begin{array}{l}0-1000 \\
F\end{array}$ & $\begin{array}{l}1 \text { Second } \\
\text { Intervals }\end{array}$ & 2 & $\mathrm{~N}$ & & $\begin{array}{l}\text { Ac power available. } \\
\text { Depending on how } \\
\text { long it takes to install } \\
\text { equipment, it may be } \\
\text { possible to arrange } \\
\text { production schedule } \\
\text { to install equipment. }\end{array}$ & \\
\hline 50 & 12 & $\begin{array}{l}\text { BOP Gas } \\
\text { Clearing Open } \\
\text { Loop Make Up } \\
\text { Water Tracking }\end{array}$ & $\begin{array}{l}\text { Various Make } \\
\text { up water flow } \\
\text { meters. }\end{array}$ & $\begin{array}{l}\text { Flow meters } \\
\text { for makeup } \\
\text { water lines }\end{array}$ & $\begin{array}{l}0-300 \\
\text { GPM }\end{array}$ & $\begin{array}{l}5 \text { Second } \\
\text { Intervals }\end{array}$ & 1 & $\mathrm{~N}$ & & $\begin{array}{l}\text { Depending on } \\
\text { installation time, } \\
\text { probe could be } \\
\text { installed at any time. }\end{array}$ & $\frac{\frac{12 \text { BOP GC }}{\text { Water Make }}}{\underline{\text { Up }}}$ \\
\hline
\end{tabular}




\begin{tabular}{|c|c|c|c|c|c|c|c|c|c|c|c|}
\hline Line & $\begin{array}{l}\text { Critic } \\
\text { ality }\end{array}$ & Process & Process Entity & $\begin{array}{c}\text { Measurement } \\
\text { Observation }\end{array}$ & Range & $\begin{array}{l}\text { Sampling } \\
\text { Rate }\end{array}$ & $\begin{array}{c}\text { Projected } \\
\text { Number of } \\
\text { Measurement } \\
\text { Points }\end{array}$ & $\begin{array}{l}\text { Current } \\
\text { or New } \\
\text { Sensor } \\
\text { (C or N) }\end{array}$ & $\begin{array}{c}\text { Environment } \\
\text { al Stressors }\end{array}$ & $\begin{array}{l}\text { Operational } \\
\text { Restrictions }\end{array}$ & Links \\
\hline 51 & \multirow[t]{3}{*}{13} & \multirow[t]{3}{*}{$\begin{array}{l}\text { Degasser Steam } \\
\text { Flow }\end{array}$} & Degasser & Steam Flow & $\begin{array}{l}0- \\
80.000 \\
\text { LBS/HR }\end{array}$ & $\begin{array}{l}3 \text { Second } \\
\text { Intervals }\end{array}$ & 1 & $\mathrm{~N}$ & $\begin{array}{l}\text { Heat } 130 \text { F, } \\
\text { Dirt, Steam. }\end{array}$ & $\begin{array}{l}\text { AC power available. } \\
\text { Must be installed } \\
\text { when Degasser is not } \\
\text { in operation. }\end{array}$ & \\
\hline 52 & & & Degasser & $\begin{array}{l}\text { Steam } \\
\text { Temperature }\end{array}$ & $\begin{array}{l}0-800 \\
\text { DEG F }\end{array}$ & $\begin{array}{l}3 \text { Second } \\
\text { Intervals }\end{array}$ & 1 & $\mathrm{~N}$ & $\begin{array}{l}\text { Heat } \sim 130 \mathrm{~F} \text {, } \\
\text { Dirt, Steam. }\end{array}$ & $\begin{array}{l}\text { AC power available. } \\
\text { Must be installed } \\
\text { when Degasser is not } \\
\text { in operation. }\end{array}$ & \\
\hline 53 & & & Degasser & $\begin{array}{l}\text { Steam } \\
\text { Pressure }\end{array}$ & $\begin{array}{l}0-300 \\
\text { PSIG }\end{array}$ & $\begin{array}{l}3 \text { Second } \\
\text { Intervals }\end{array}$ & 1 & $\mathrm{~N}$ & $\begin{array}{l}\text { Heat } \sim 130 \mathrm{~F} \text {, } \\
\text { Dirt, Steam. }\end{array}$ & $\begin{array}{l}\text { AC power available. } \\
\text { Must be installed } \\
\text { when Degasser is not } \\
\text { in operation. }\end{array}$ & \\
\hline 54 & 14 & $\begin{array}{l}\text { Mixer Bag } \\
\text { House Efficiency }\end{array}$ & $\begin{array}{l}\text { Mixer } \\
\text { Baghouse } \\
\text { Compartments } \\
\end{array}$ & Air Flows & $\begin{array}{l}600,000 \\
\text { CFM }\end{array}$ & $\begin{array}{l}3 \text { Second } \\
\text { Intervals }\end{array}$ & 1 & $\mathrm{~N}$ & $\begin{array}{l}\text { Heat 130 F, } \\
\text { Dirt, } \\
\text { weather. }\end{array}$ & $\begin{array}{l}\text { AC power available. } \\
\text { Vendor to determine } \\
\text { if the meters can be } \\
\text { installed while the } \\
\text { baghouse is operating. } \\
\text { If not downturn } \\
\text { required. }\end{array}$ & $\underline{14 \text { Mixer }}$ \\
\hline 55 & 15 & $\begin{array}{l}\text { Fugitive Bag } \\
\text { House Efficiency }\end{array}$ & $\begin{array}{l}\text { Fugitive } \\
\text { Baghouse } \\
\text { Compartments } \\
\end{array}$ & Air Flows & $\begin{array}{l}900,000 \\
\text { CFM }\end{array}$ & $\begin{array}{l}3 \text { Second } \\
\text { Intervals }\end{array}$ & 1 & $\mathrm{~N}$ & $\begin{array}{l}\text { Heat } \sim 130 \mathrm{~F} \text {, } \\
\text { Dirt, } \\
\text { weather. }\end{array}$ & $\begin{array}{l}\text { AC power available. } \\
\text { Vendor to determine } \\
\text { if the meters can be } \\
\text { installed while the } \\
\text { baghouse is operating. } \\
\text { If not downturn } \\
\text { required. }\end{array}$ & 15 Fugitive \\
\hline 56 & 16 & $\begin{array}{l}\text { Blast Furnace } \\
\text { Bag House } \\
\text { Efficiency }\end{array}$ & $\begin{array}{l}\text { Blast Furnace } \\
\text { Baghouse } \\
\text { Compartments } \\
\end{array}$ & Air Flows & $\begin{array}{l}400,000 \\
\text { CFM }\end{array}$ & $\begin{array}{l}3 \text { Second } \\
\text { Intervals }\end{array}$ & 1 & $\mathrm{~N}$ & $\begin{array}{l}\text { Heat 130 F, } \\
\text { Dirt, } \\
\text { weather. }\end{array}$ & $\begin{array}{l}\text { AC power available. } \\
\text { Vendor to determine } \\
\text { if the meters can be } \\
\text { installed while the } \\
\text { baghouse is operating. } \\
\text { If not downturn } \\
\text { required. }\end{array}$ & $\frac{16 \text { Blast }}{\underline{\text { Furnace }}}$ \\
\hline 57 & 17 & $\begin{array}{l}\text { Chem Treat } \\
\text { Water Systems }\end{array}$ & $\begin{array}{l}\text { Various Water } \\
\text { systems }\end{array}$ & ORP Probes & $\begin{array}{l}-999 \text { to } \\
999 \mathrm{mV}\end{array}$ & $\begin{array}{l}5 \text { Second } \\
\text { Intervals }\end{array}$ & & $\mathrm{N}$ & $\begin{array}{l}\text { Heat } \sim 130 \mathrm{~F} \text {, } \\
\text { Dirt, } \\
\text { weather. }\end{array}$ & & \\
\hline
\end{tabular}




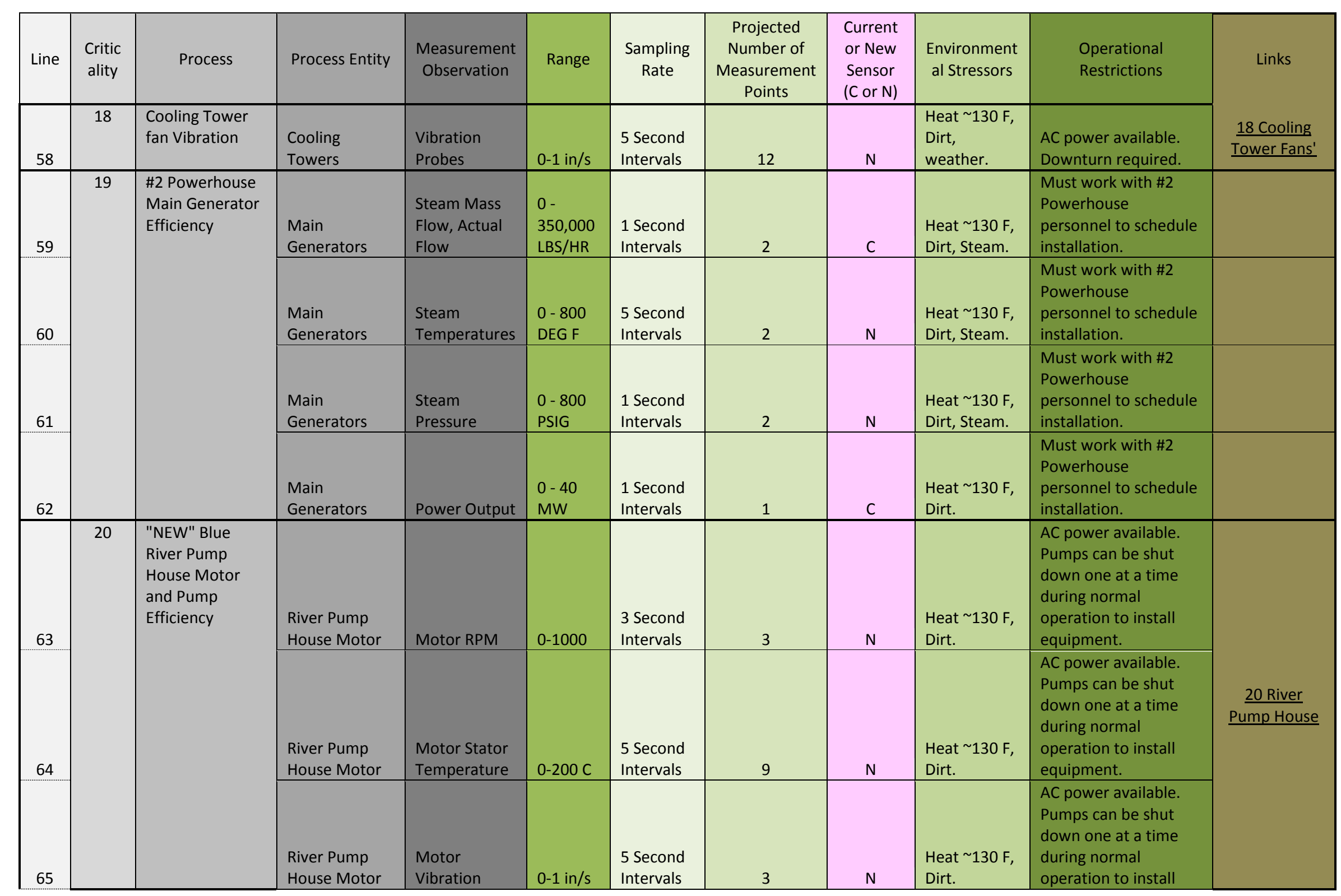




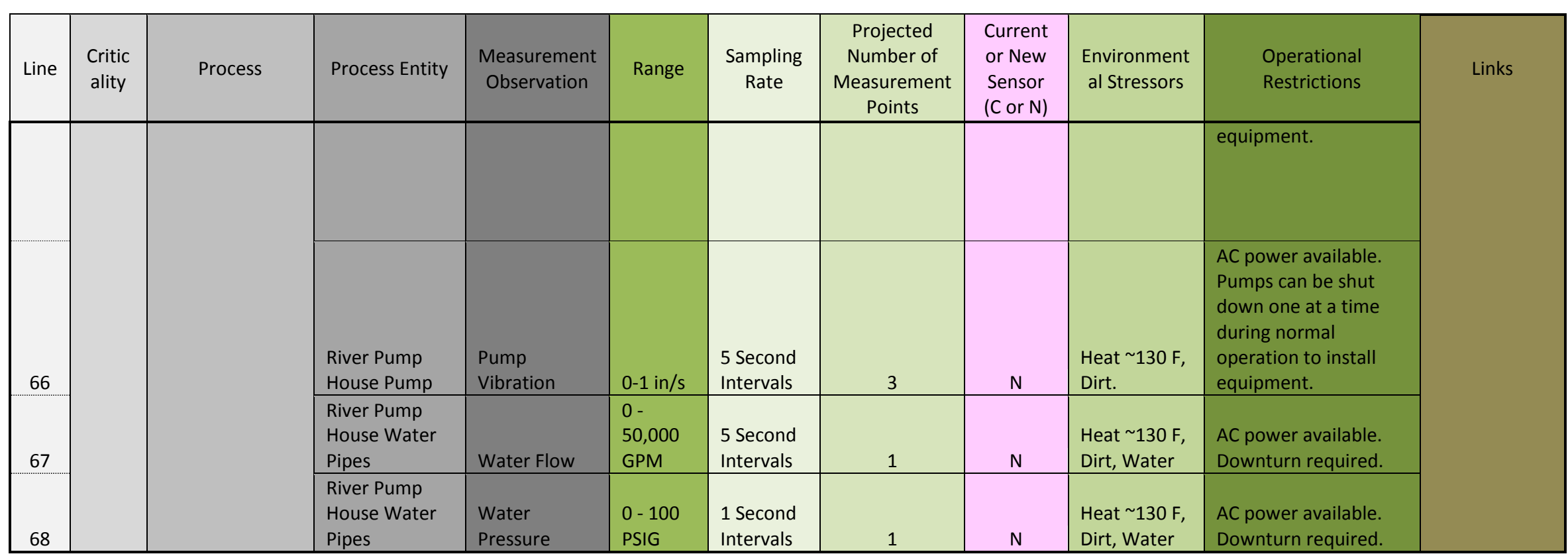


Table 6. Photographs of all Equipment Installed by Andrews at E.T. Plant

\begin{tabular}{|c|c|c|c|}
\hline Location/Process & Process Entity & Measurement Observation & Reference \\
\hline Caster & Main Radio Unit & Radio & Photo A \\
\hline Caster & HP Server & Server & Photo B \\
\hline Caster & HP Firewall & Firewall & Photo B \\
\hline \multirow{5}{*}{ BOP - Davey 1} & \multirow{5}{*}{ Gas Flow } & Coke Oven Gas Flow & Photo D \\
\hline & & Coke Oven Gas Pressure & Photo E \\
\hline & & Coke Oven Gas Temperature & Photo $\mathrm{F}$ \\
\hline & & Radio & Photo C \\
\hline & & Antenna & Photo G \\
\hline \multirow{5}{*}{ BOP - Davey 3} & \multirow{5}{*}{ Gas Flow } & Coke Oven Gas Flow & Photo I \\
\hline & & Coke Oven Gas Pressure & Photo J \\
\hline & & Coke Oven Gas Temperature & Photo K \\
\hline & & Radio & Photo H \\
\hline & & Antenna & Photo J \\
\hline \multirow{18}{*}{$\begin{array}{c}\text { \#2 Powerhouse, } \\
\text { Boiler \#3 }\end{array}$} & \multirow{5}{*}{ Coke Gas } & Coke Oven Gas Flow & Photo M \\
\hline & & Coke Oven Gas Pressure & Photo M \\
\hline & & Coke Oven Gas Temperature & Photo M \\
\hline & & Radio & Photo L \\
\hline & & Antenna & Photo $\mathrm{N}$ \\
\hline & \multirow{5}{*}{ BF Gas } & Blast Furnace Gas Flow to boiler & Photo P \\
\hline & & Blast Furnace Gas Pressure & Photo Q \\
\hline & & Blast Furnace Gas Temperature & Photo R \\
\hline & & Radio & Photo 0 \\
\hline & & Antenna & Photo N \\
\hline & \multirow{4}{*}{ Economizer } & Economizer Inlet Temperature & Photo T \\
\hline & & Economizer Outlet Temperature & Photo U \\
\hline & & Radio & Photo S \\
\hline & & Antenna & Photo V \\
\hline & \multirow{4}{*}{ Preheater } & Preheater Inlet Temperature & Photo X \\
\hline & & Preheater Outlet Temperature & Photo Y \\
\hline & & Radio & Photo W \\
\hline & & Antenna & Photo V \\
\hline
\end{tabular}




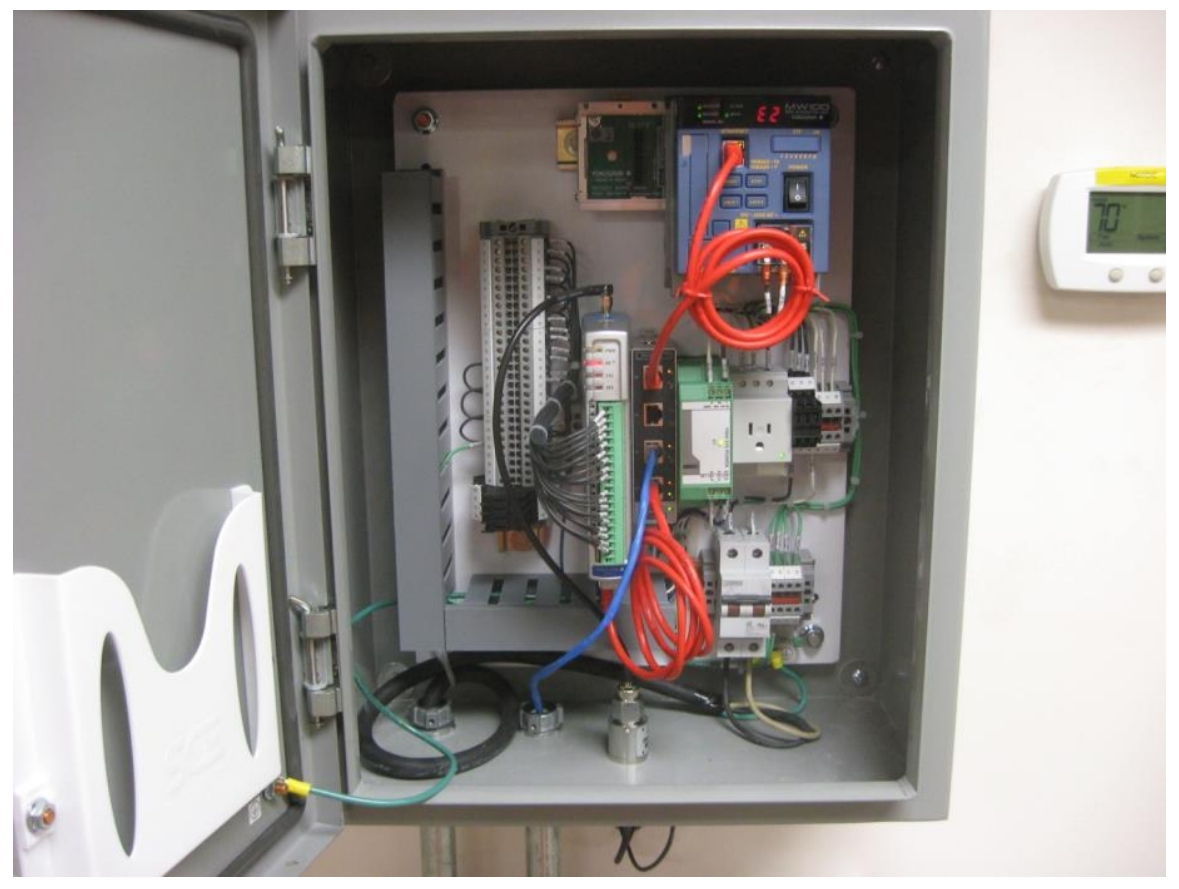

Photo A. Main Radio Unit in Caster

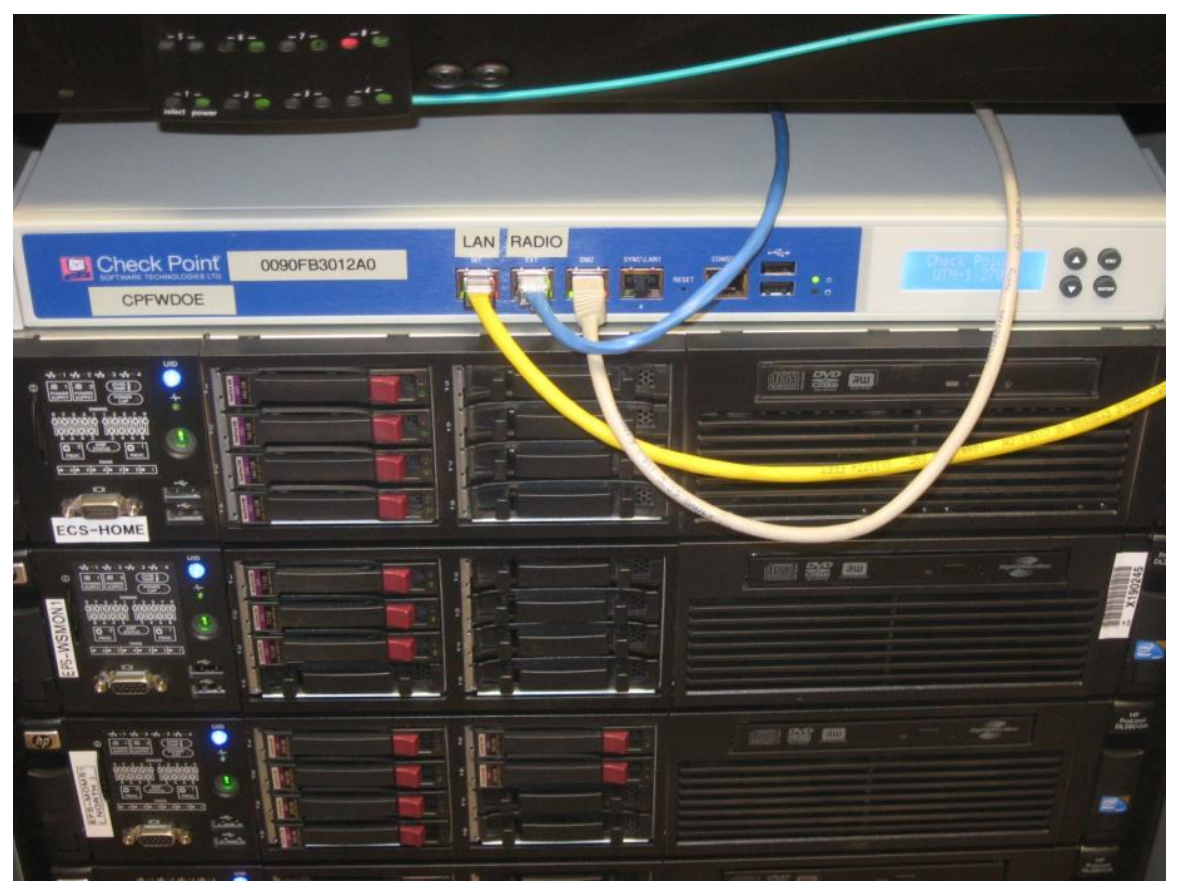

Photo B. HP Server and Firewall in Caster 


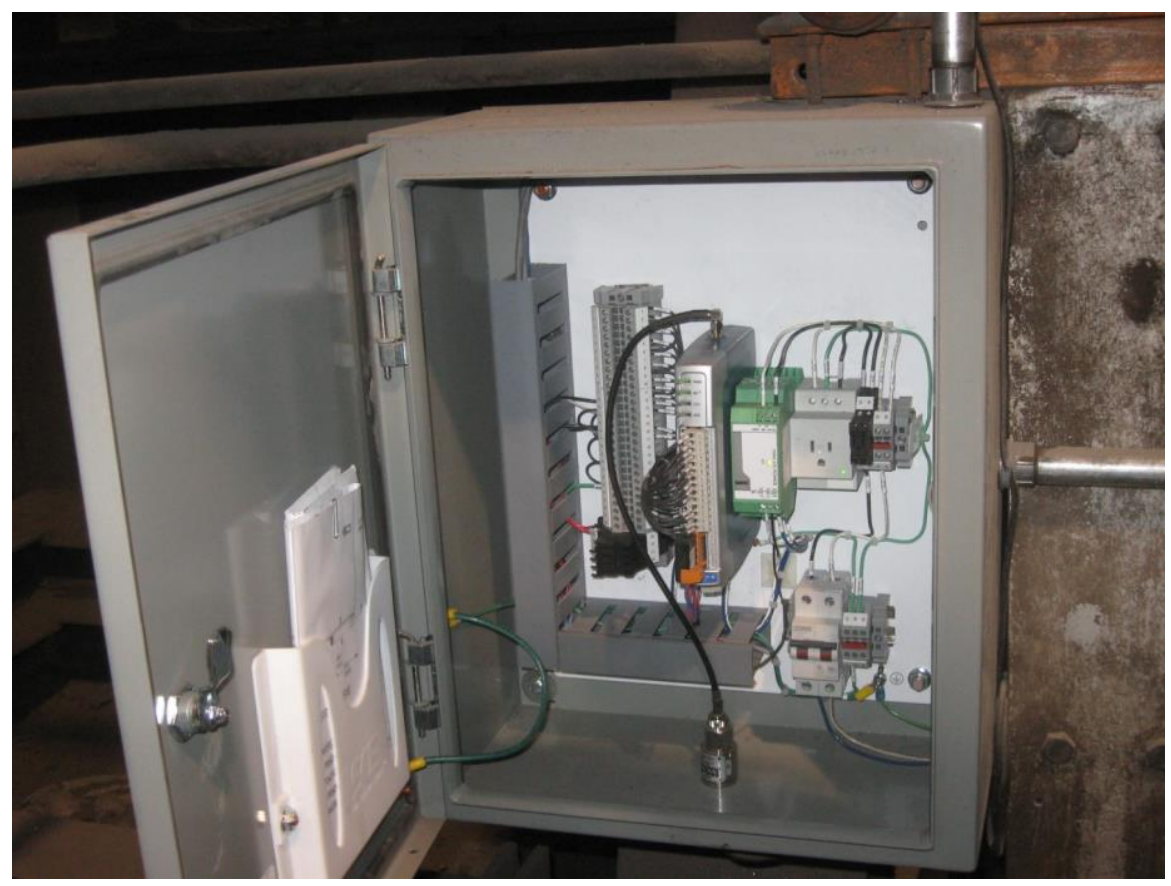

Photo C. Main Cabinet for Radio Unit for Davey 1 Preheater in BOP

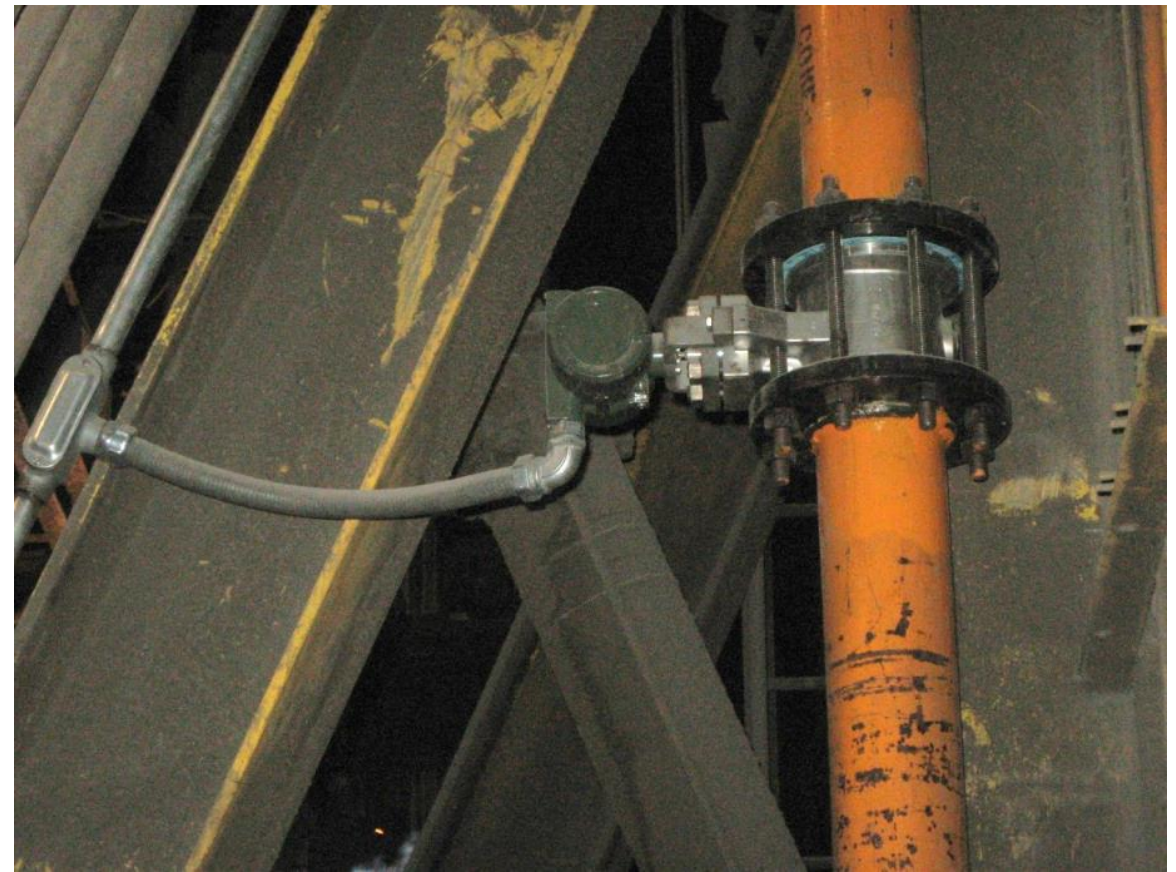

Photo D. Coke Oven Gas Flow Meter for Davey 1 Preheater in BOP 


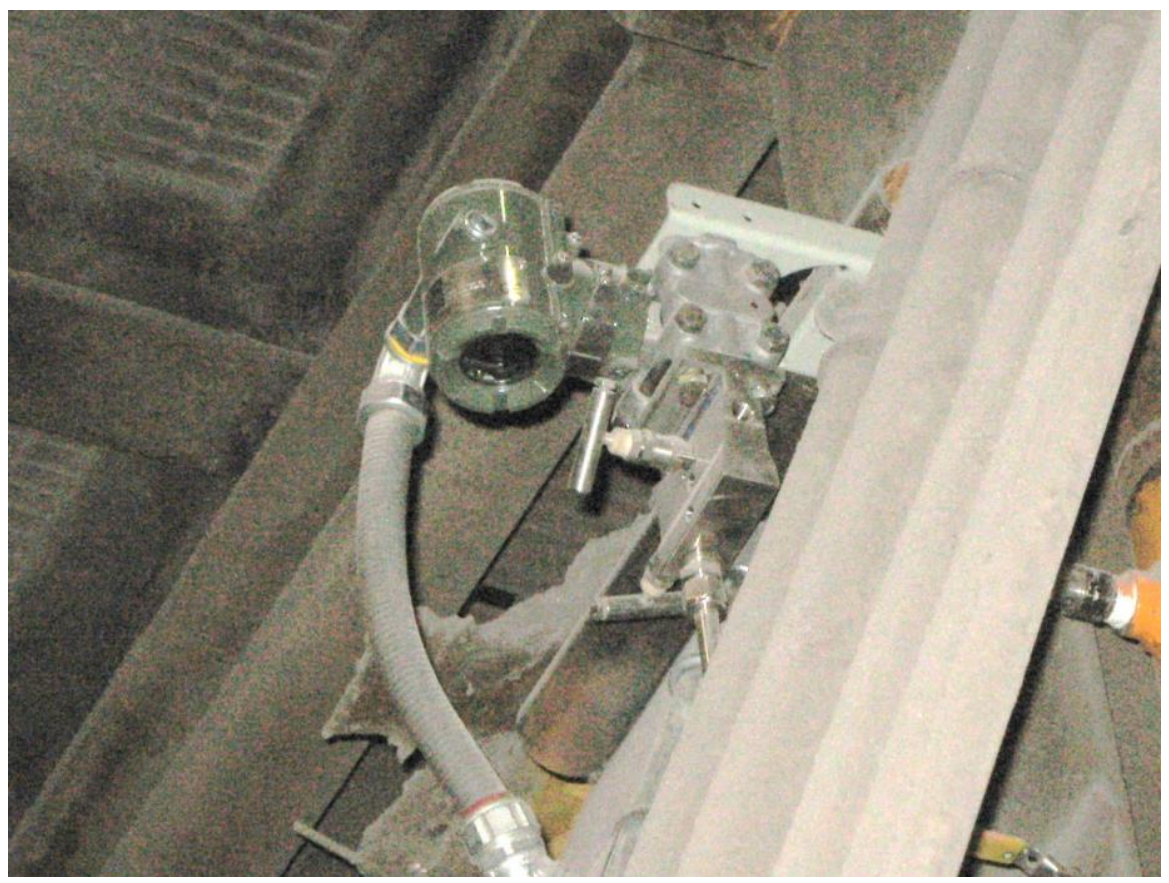

Photo E. Coke Oven Gas Pressure Meter for Davey 1 Preheater in BOP

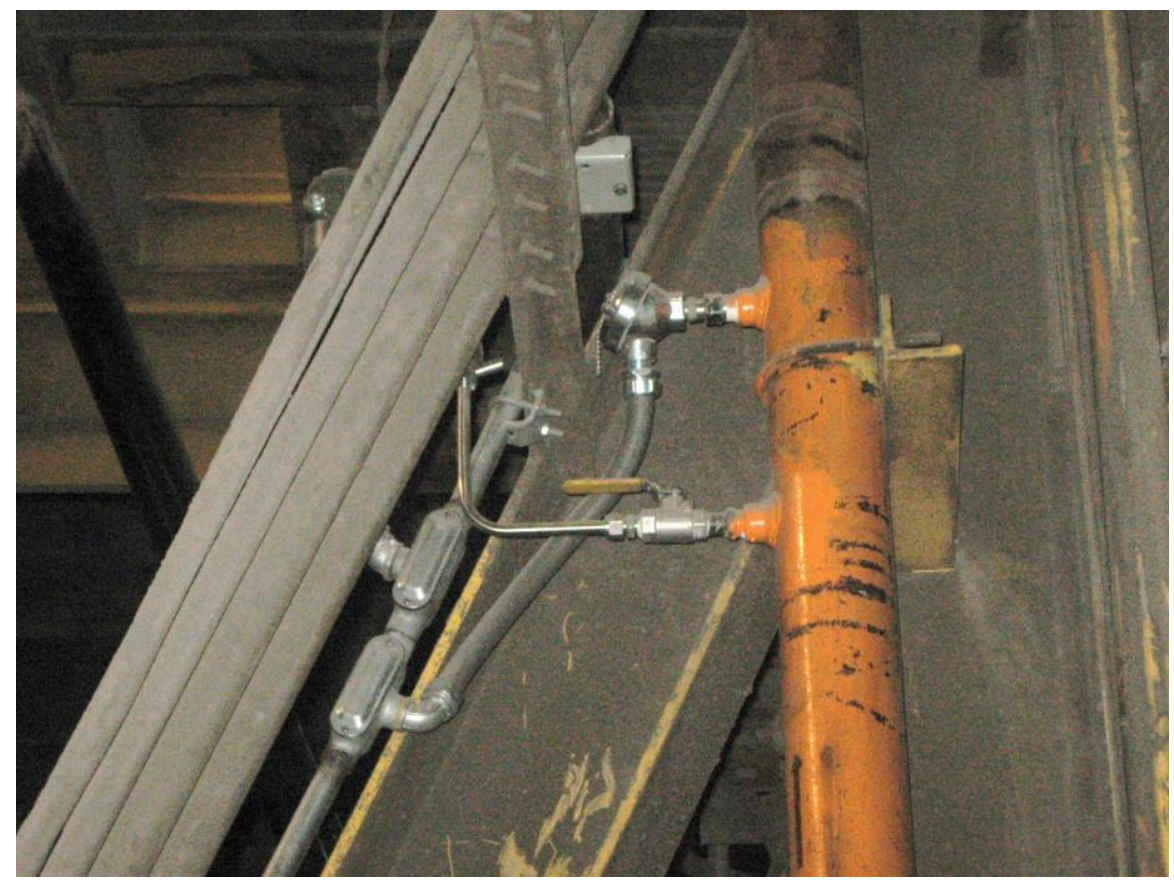

Photo F. Coke Oven Gas Temperature Probe for Davey 1 Preheater in BOP 


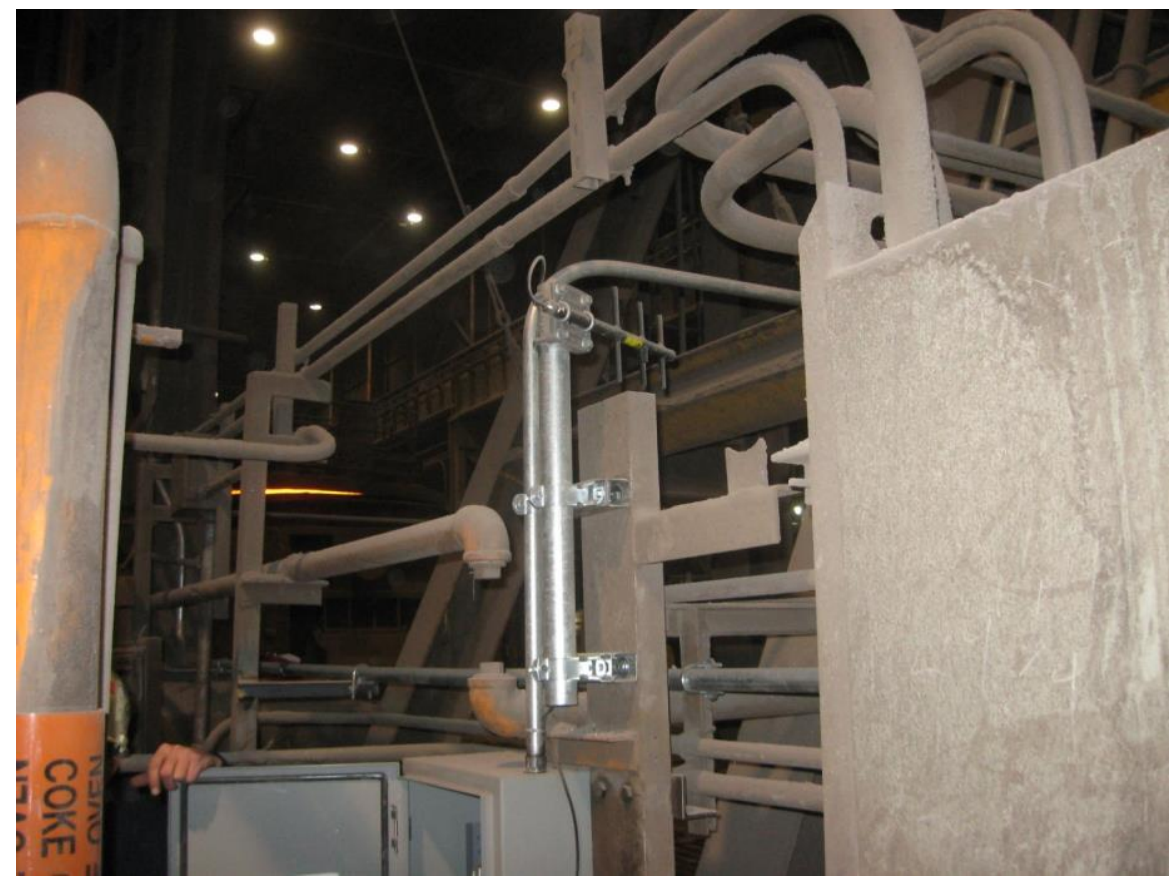

Photo G. Radio Antenna for Davey 1 Preheater in BOP

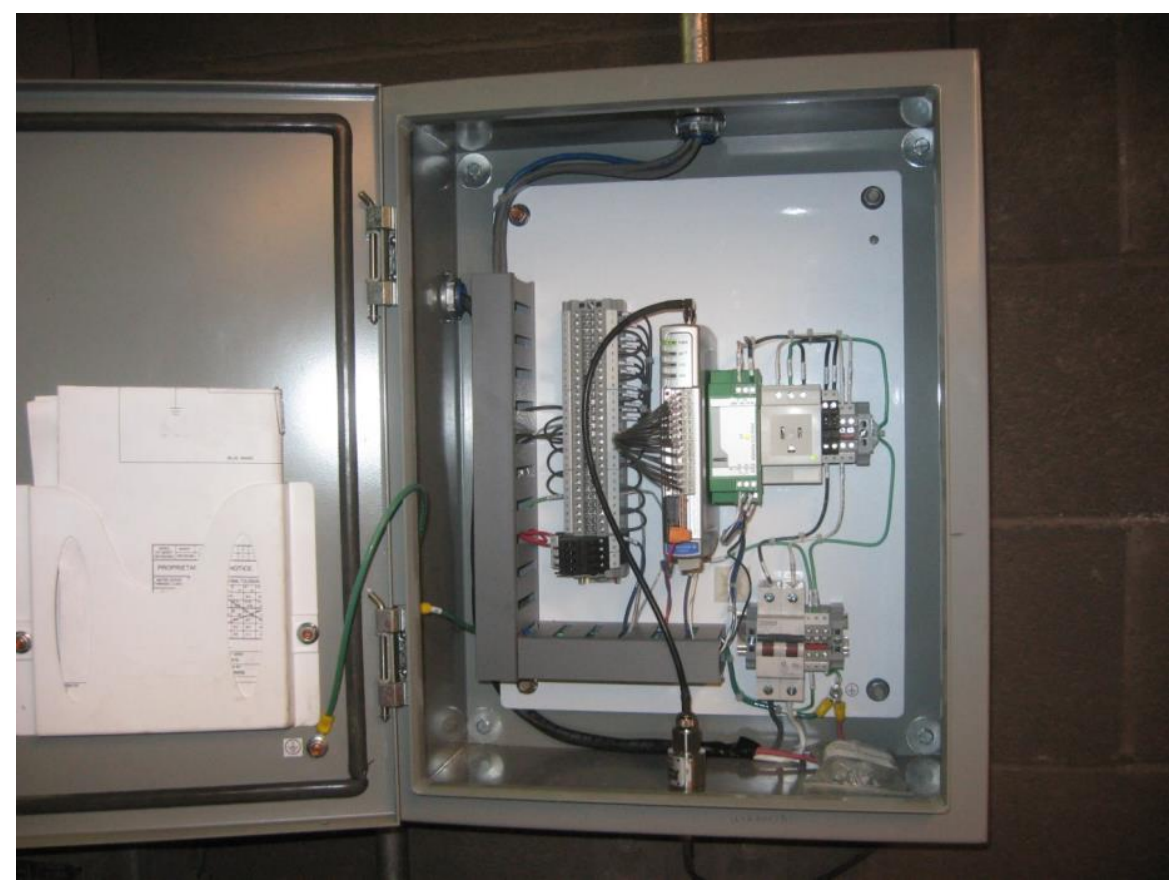

Photo H. Main Cabinet for Radio Unit for Davey 3 Preheater in BOP 


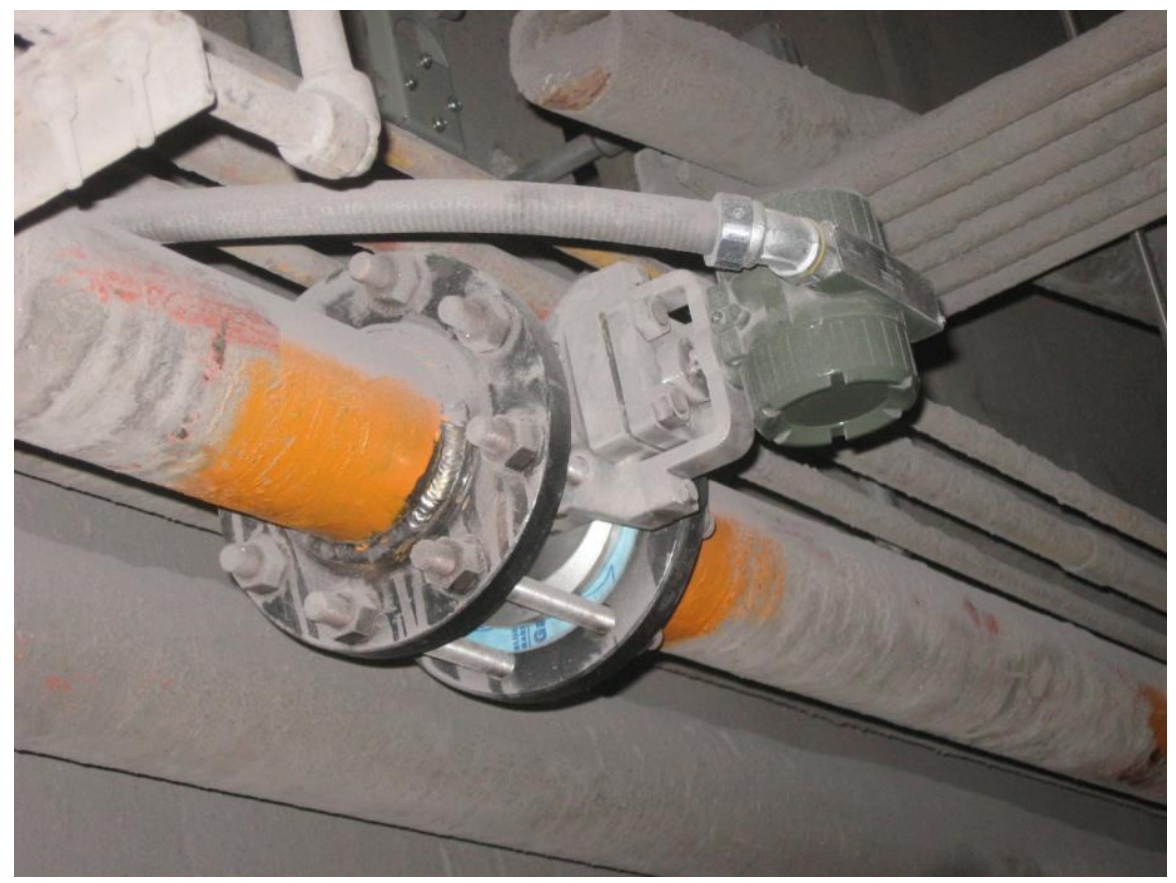

Photo I. Coke Oven Gas Flow Meter for Davey 3 Preheater in BOP

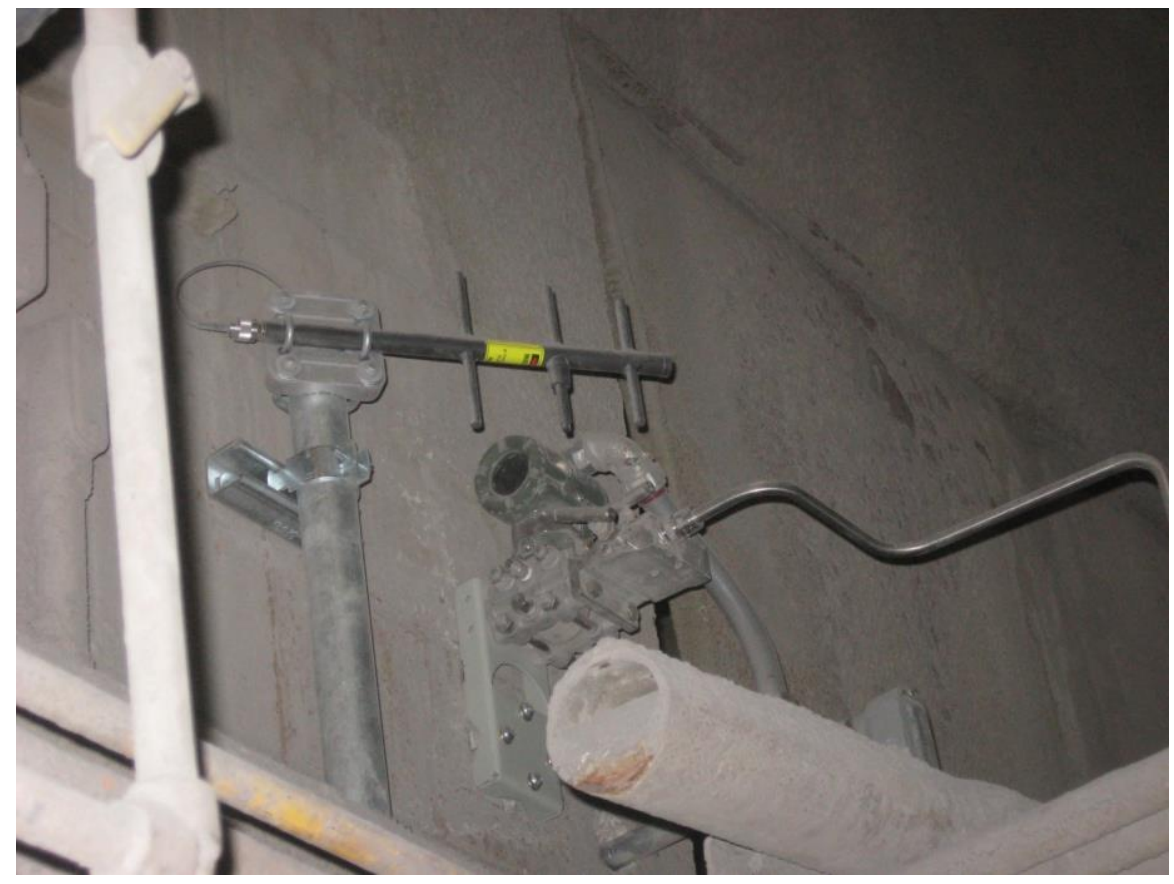

Photo J. Coke Oven Gas Pressure Meter and Radio Antenna for Davey 3 Preheater in BOP 


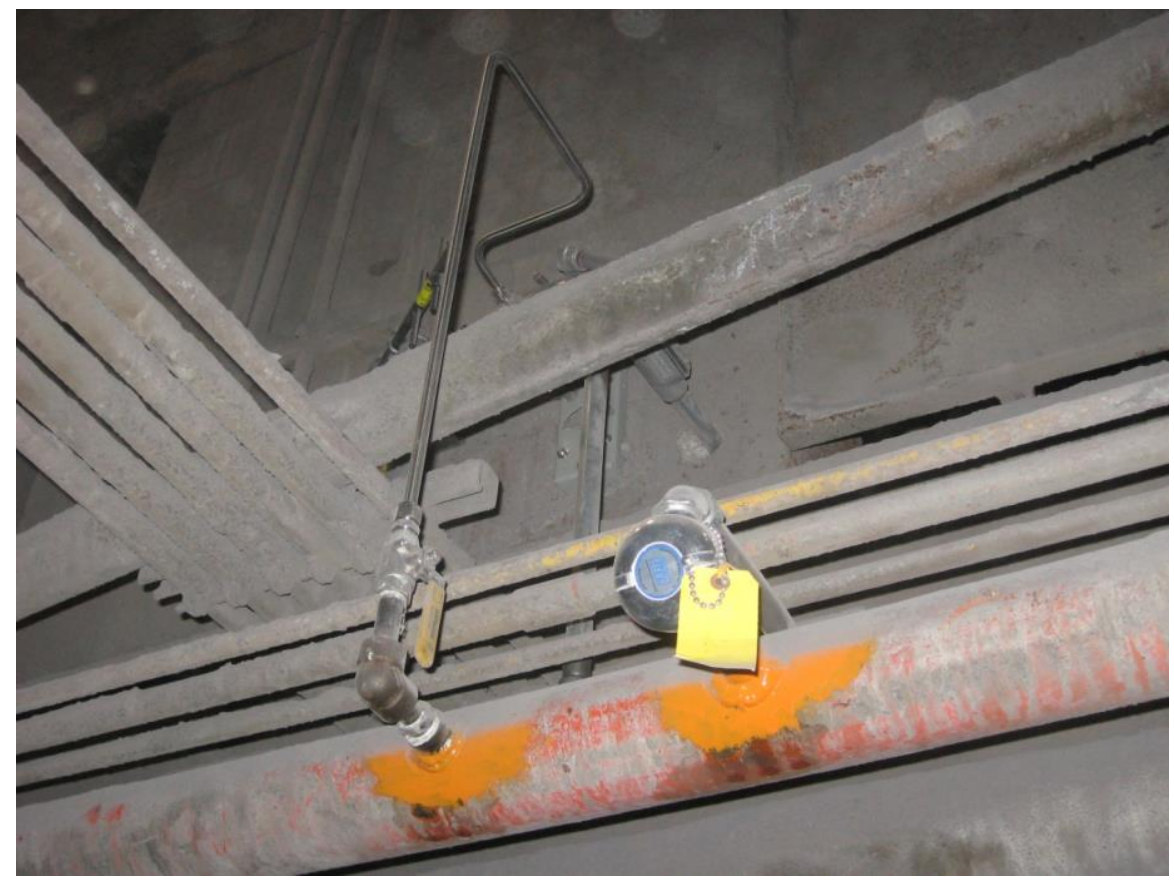

Photo K. Coke Oven Gas Temperature Probe for Davey 3 Preheater in BOP

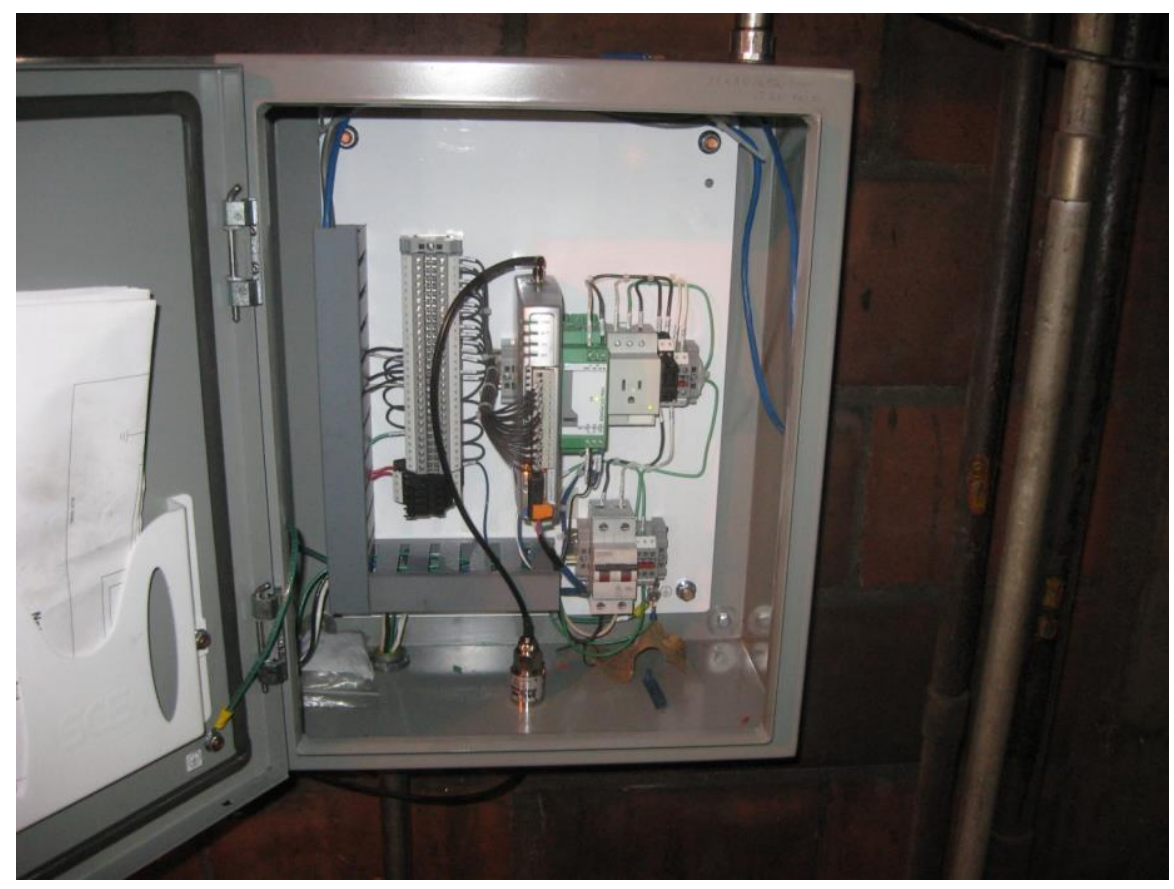

Photo L. Main Cabinet for Radio Unit for Coke Oven Gas for Boiler \#3 in \#2 Powerhouse 


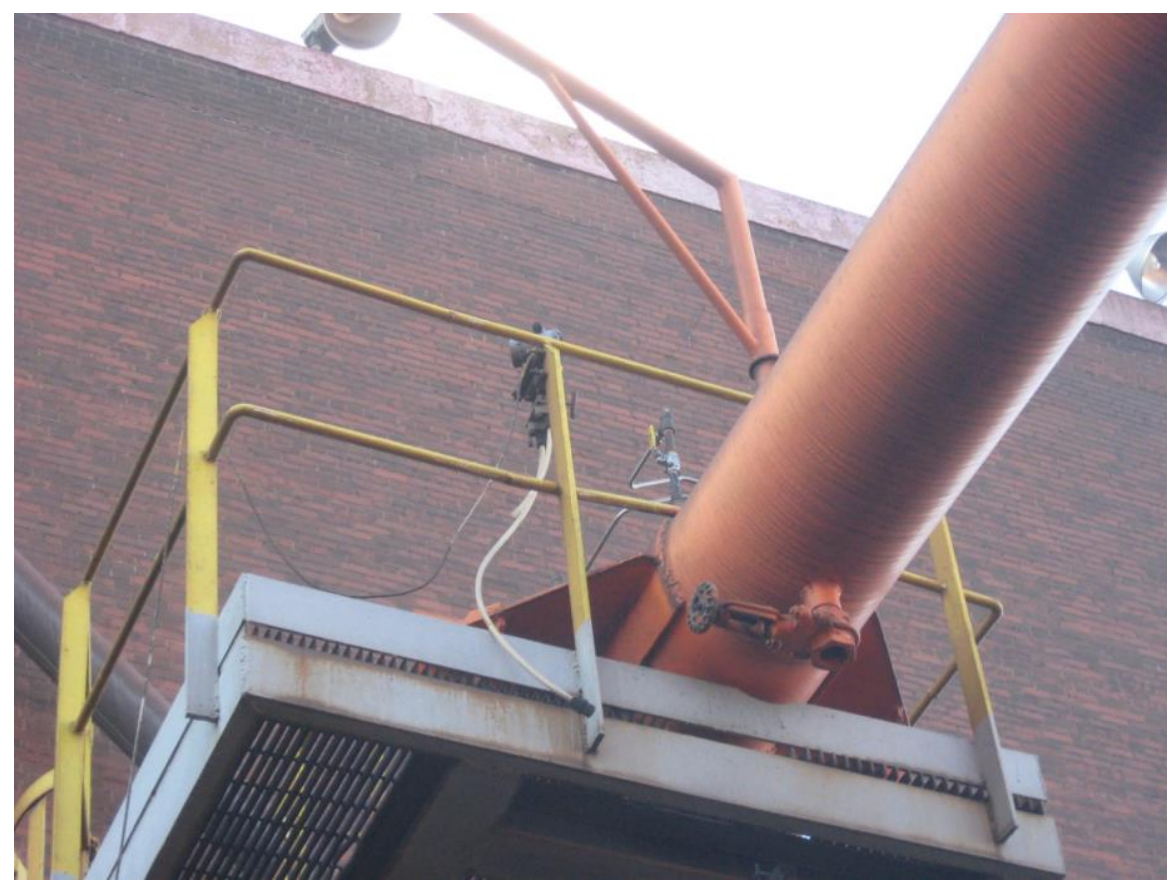

Photo M. Coke Oven Gas Flow Meter, Pressure Meter and Temperature Probe for Boiler \#3 in \#2 Powerhouse

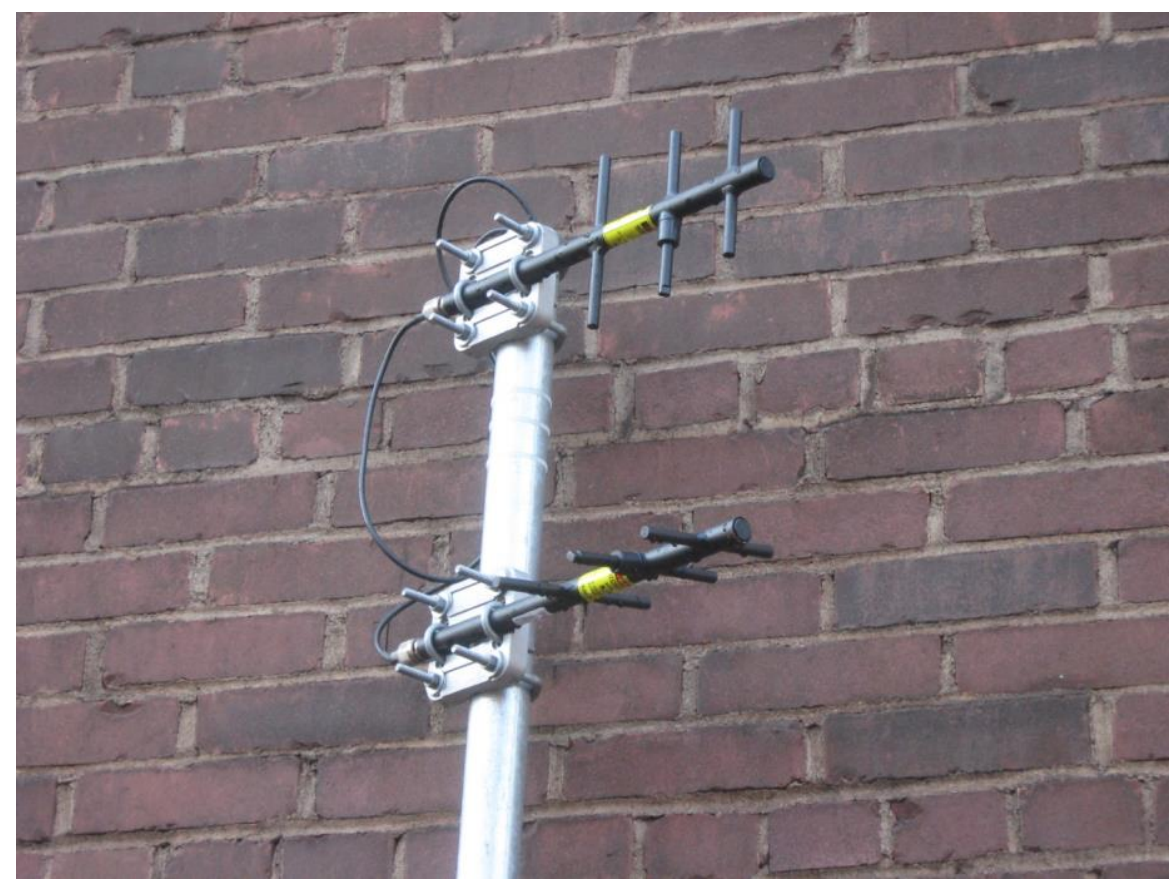

Photo N. Radio Antennas for Coke Oven Gas and Blast Furnace Gas for Boiler \#3 in \#2 Powerhouse 


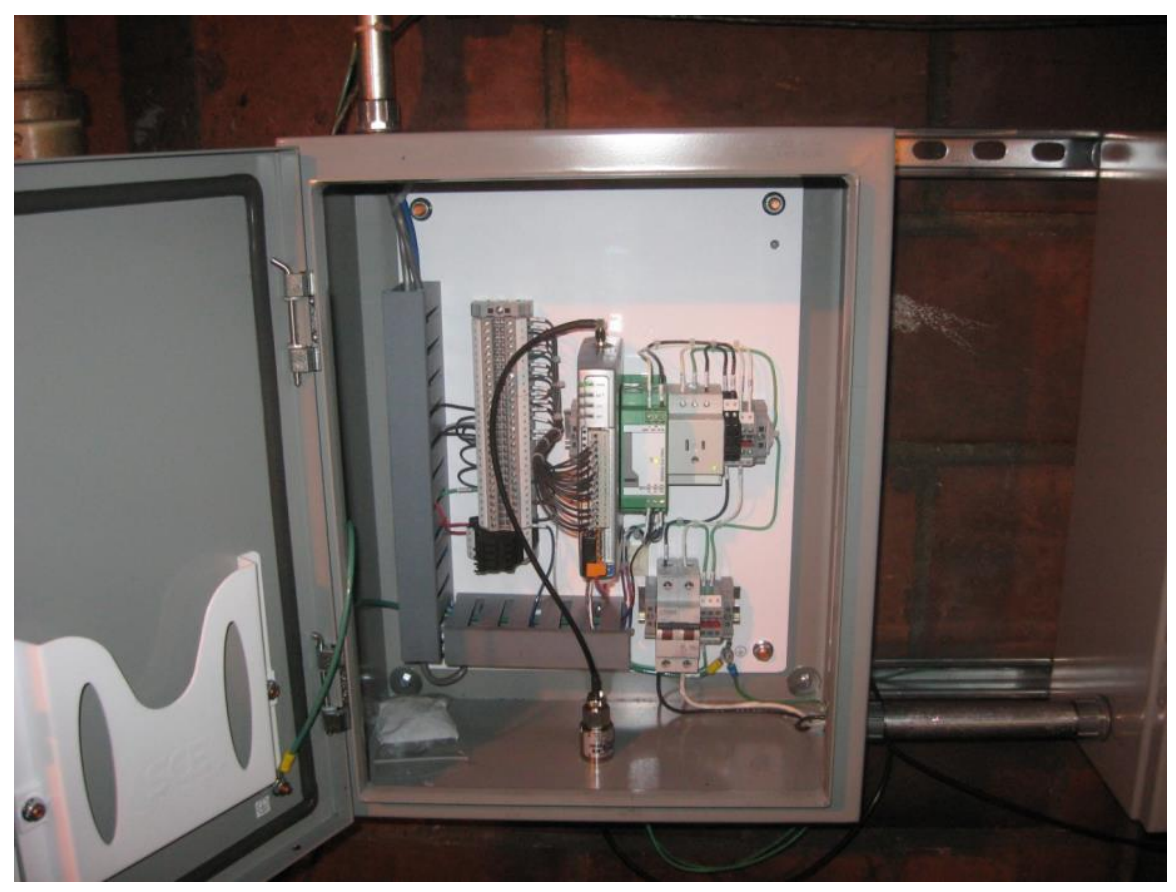

Photo O. Main Cabinet for Radio Unit for Blast Furnace Gas for Boiler \#3 in \#2 Powerhouse

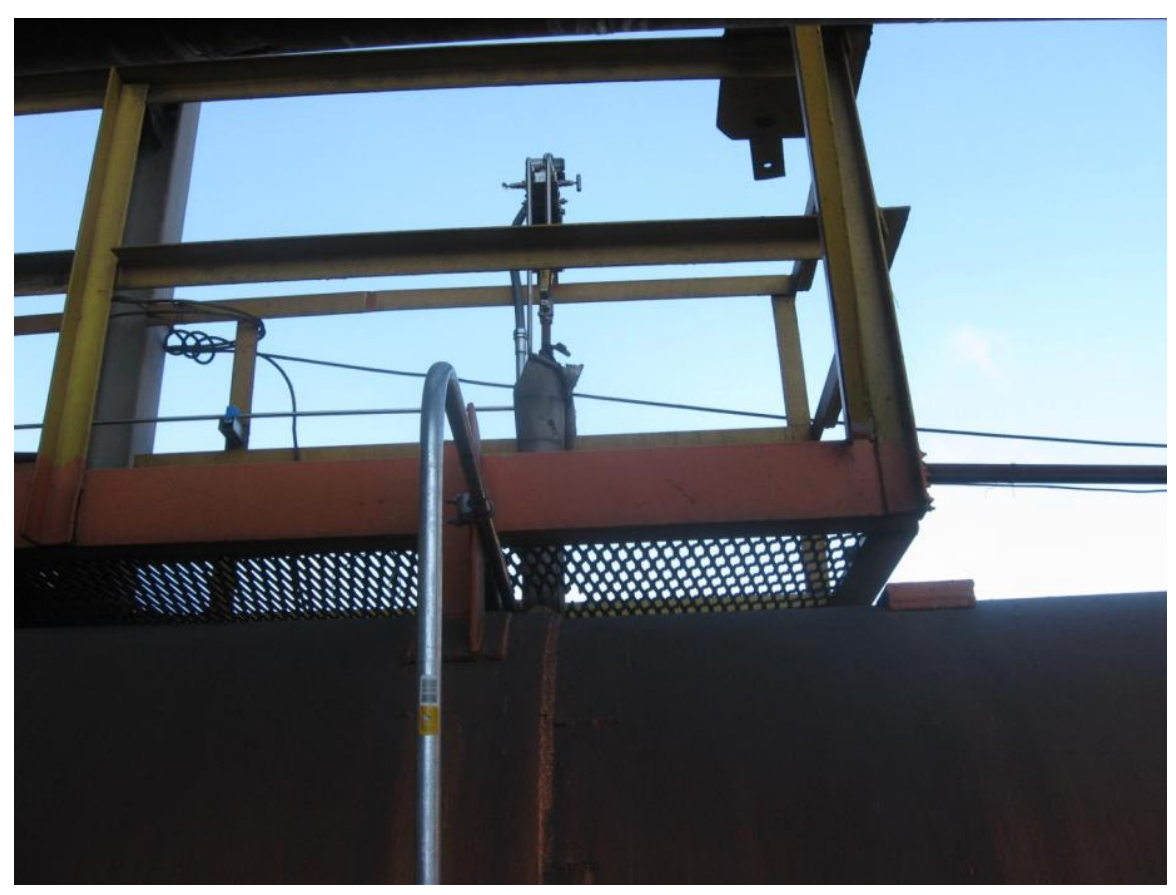

Photo P. Blast Furnace Gas Flow Meter for Boiler \#3 in \#2 Powerhouse 


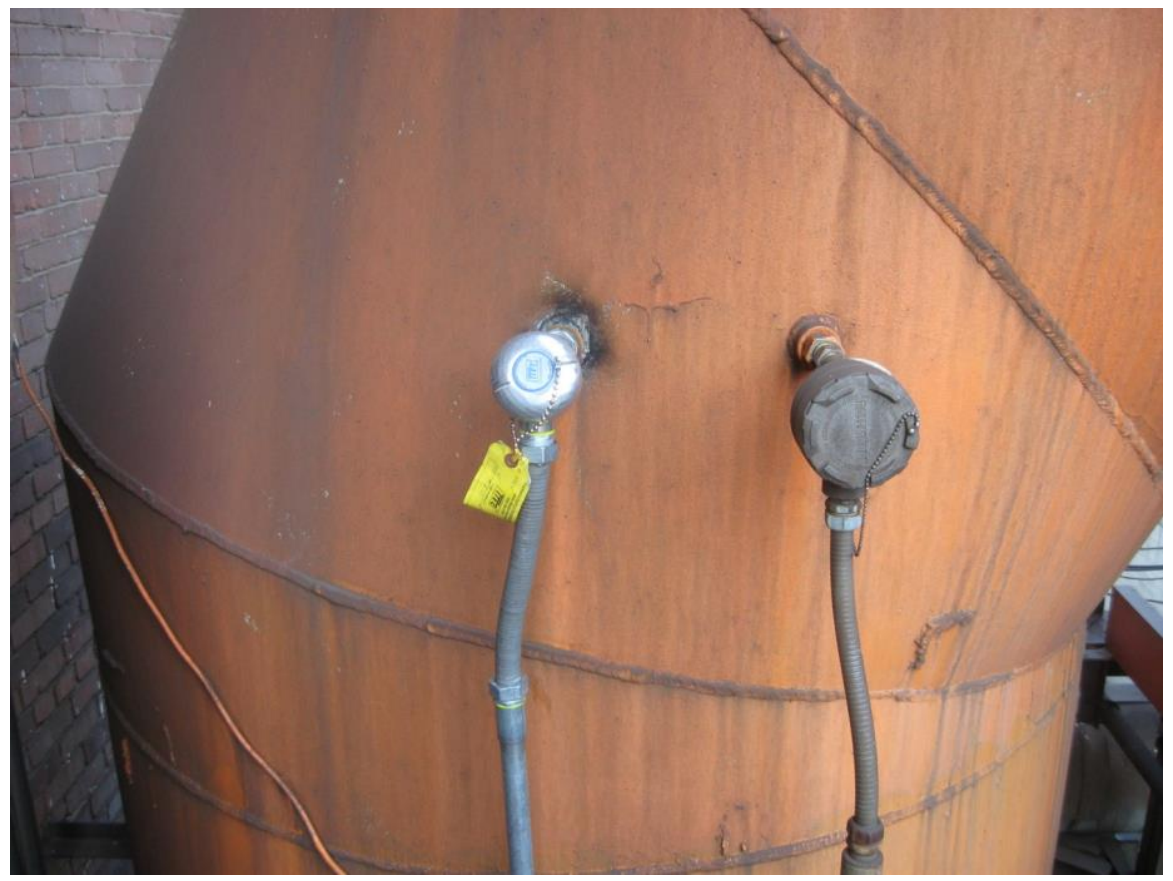

Photo Q. Blast Furnace Gas Pressure Meter for Boiler \#3 in \#2 Powerhouse

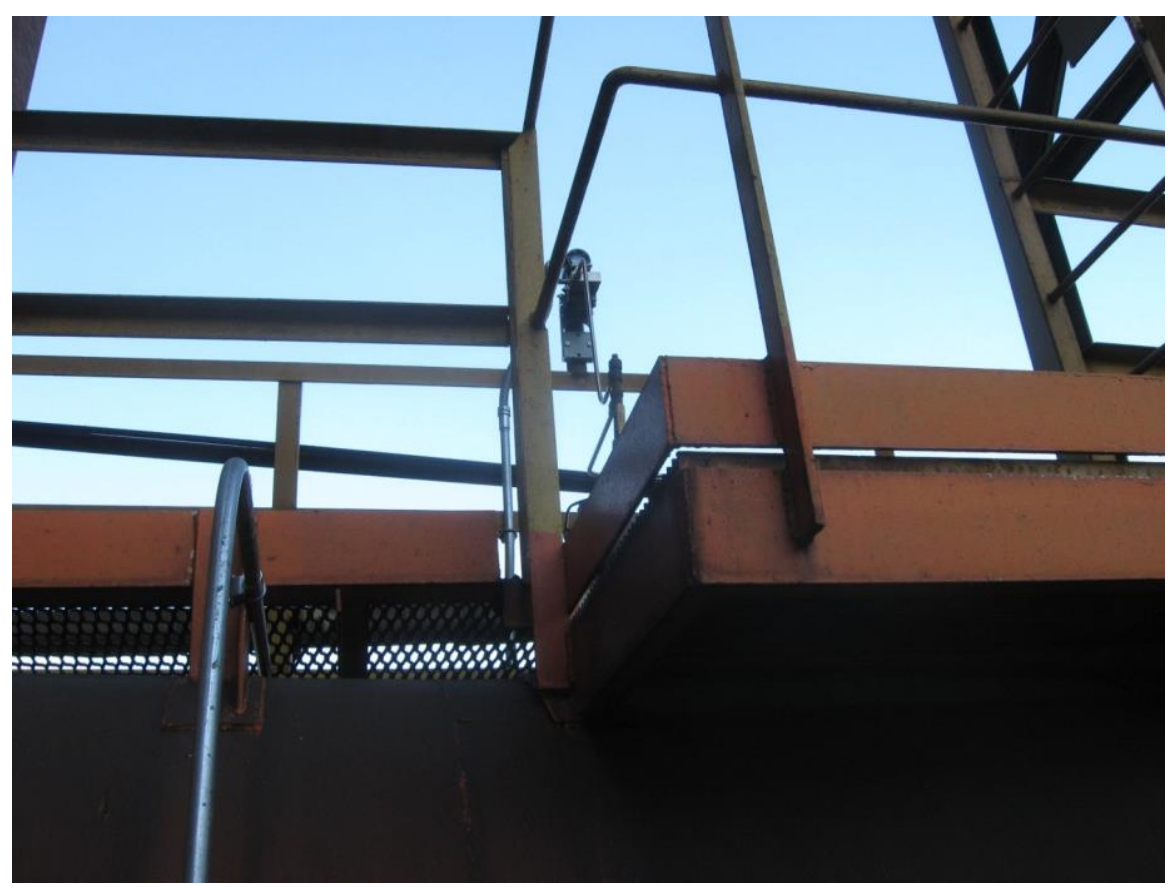

Photo R. Blast Furnace Gas Temperature Probe for Boiler \#3 in \#2 Powerhouse 


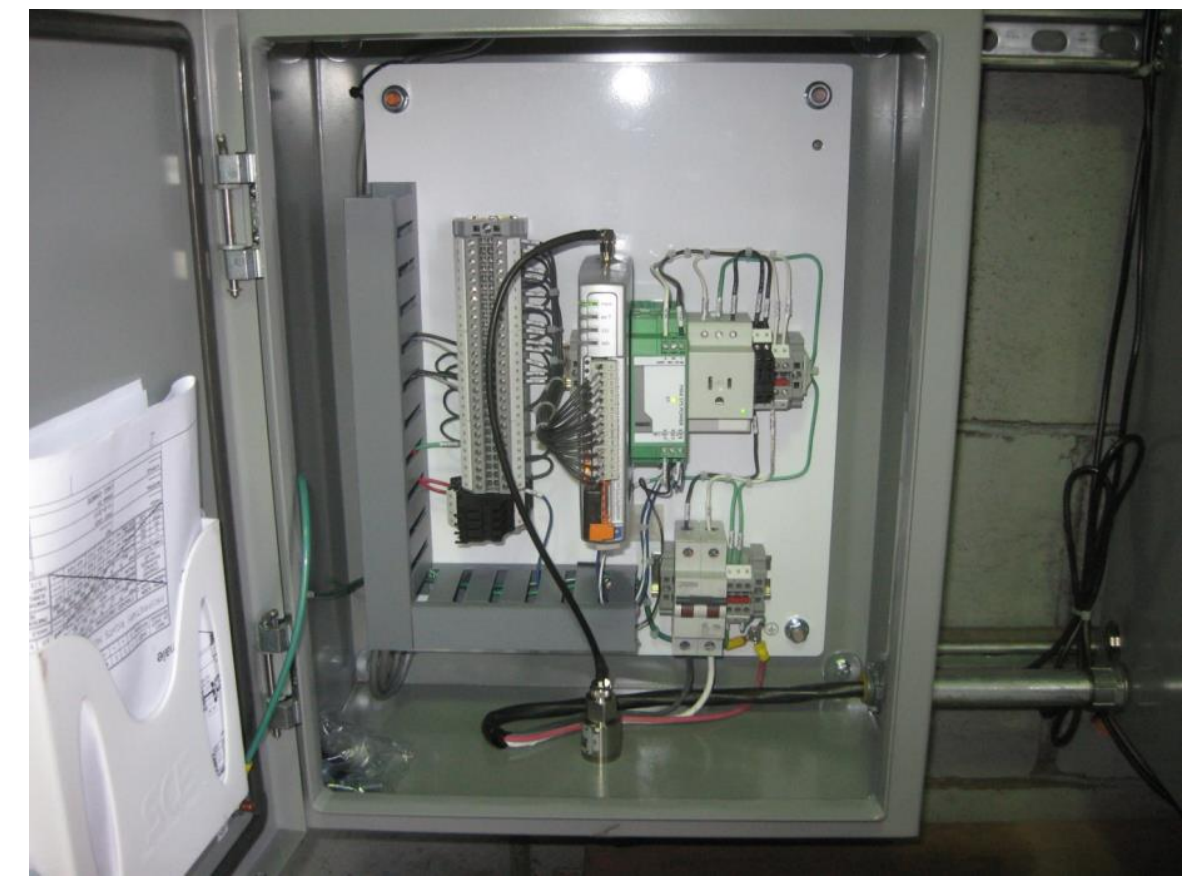

Photo S. Main Cabinet for Radio Unit for Economizer for Boiler \#3 in \#2 Powerhouse

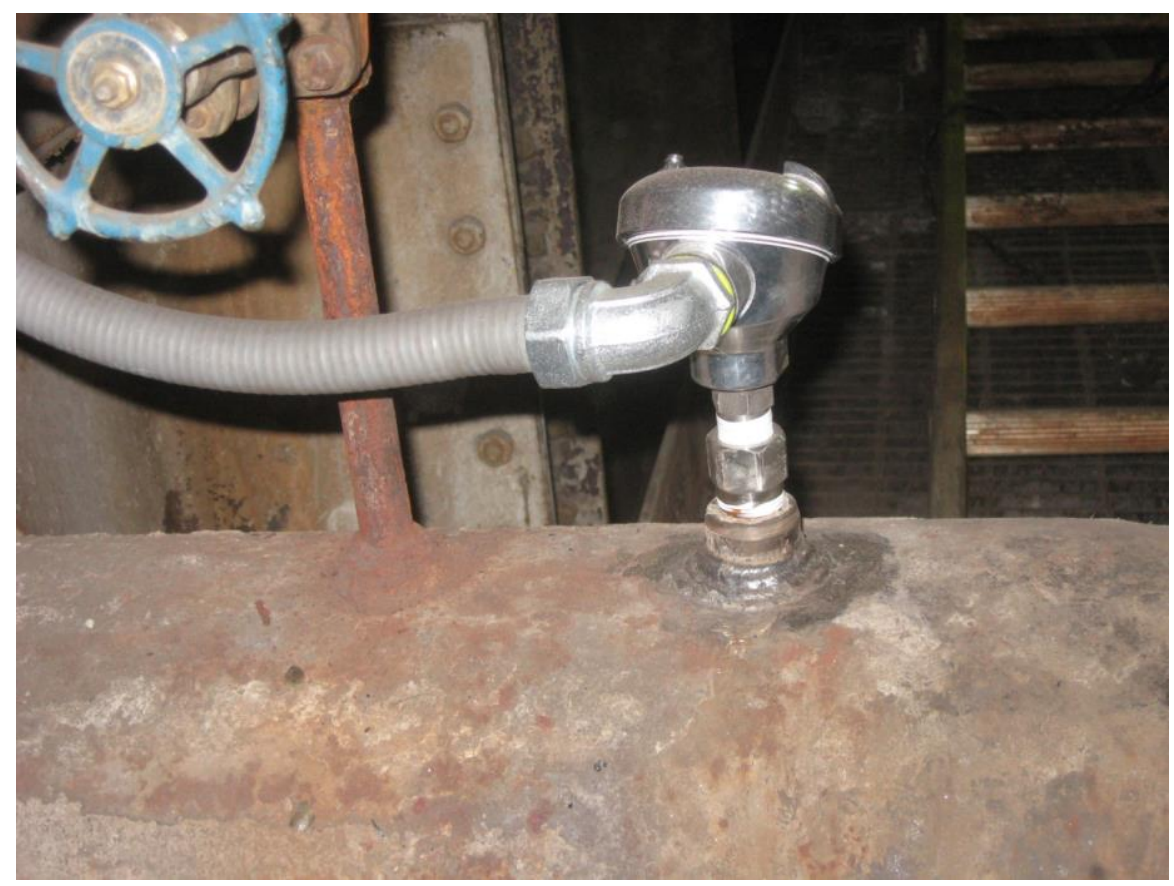

Photo T. Economizer Inlet Temperature Probe for Boiler \#3 in \#2 Powerhouse 


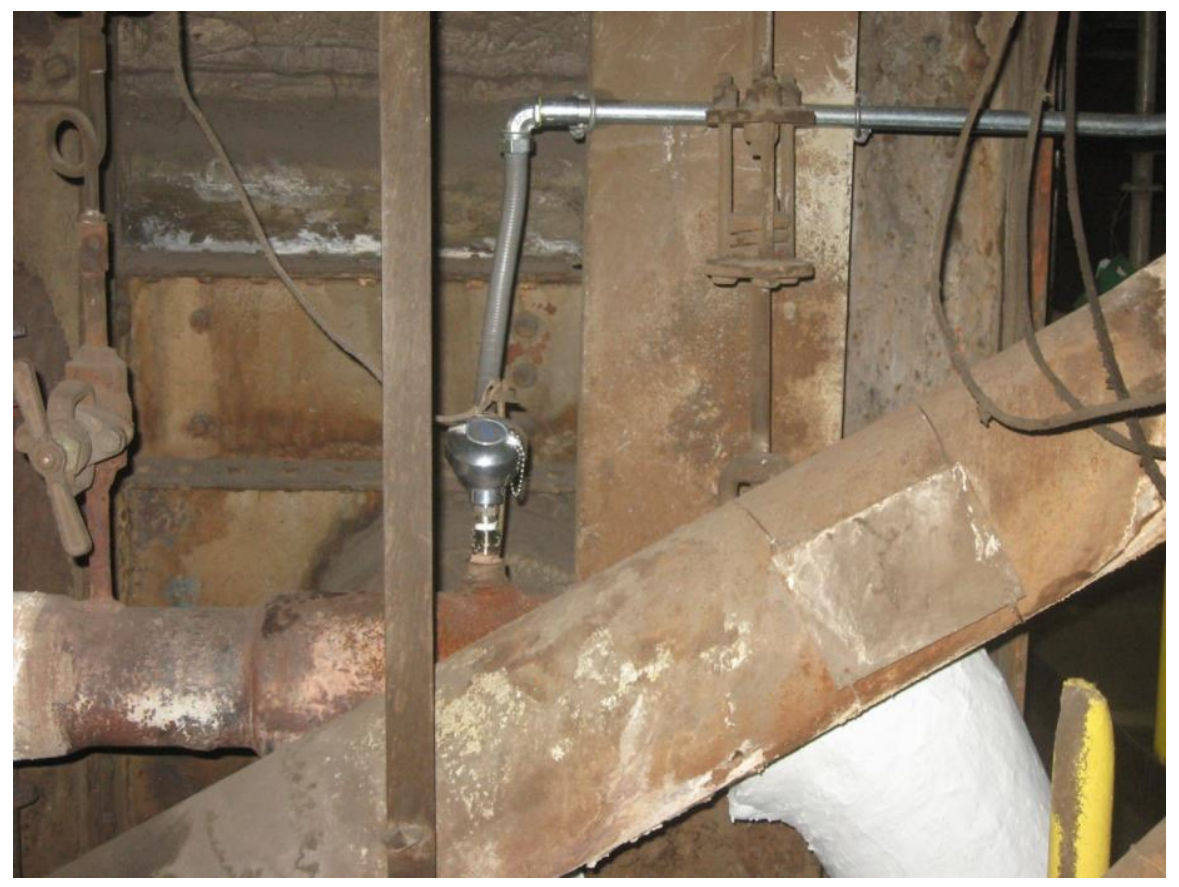

Photo U. Economizer Outlet Temperature Probe for Boiler \#3 in \#2 Powerhouse

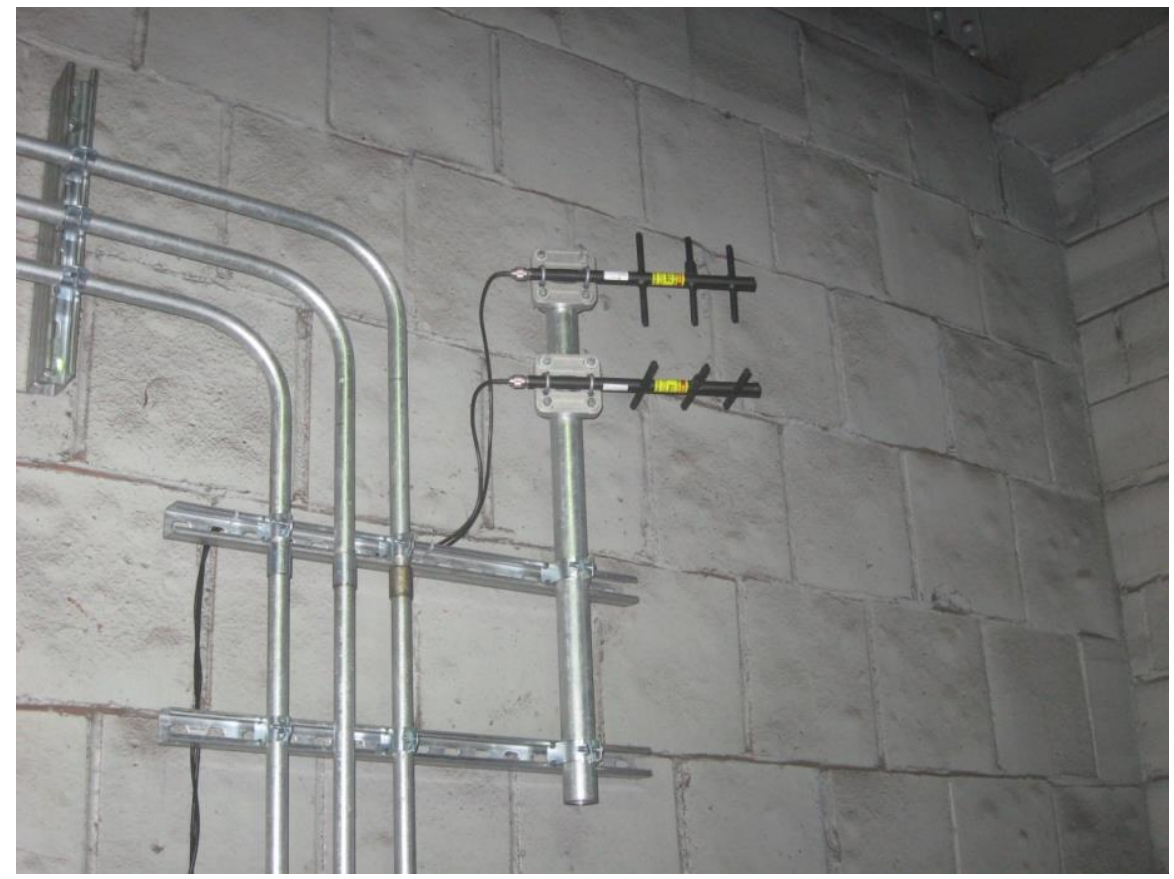

Photo V. Radio Antennas for Economizer and Preheater for Boiler \#3 in \#2 Powerhouse 


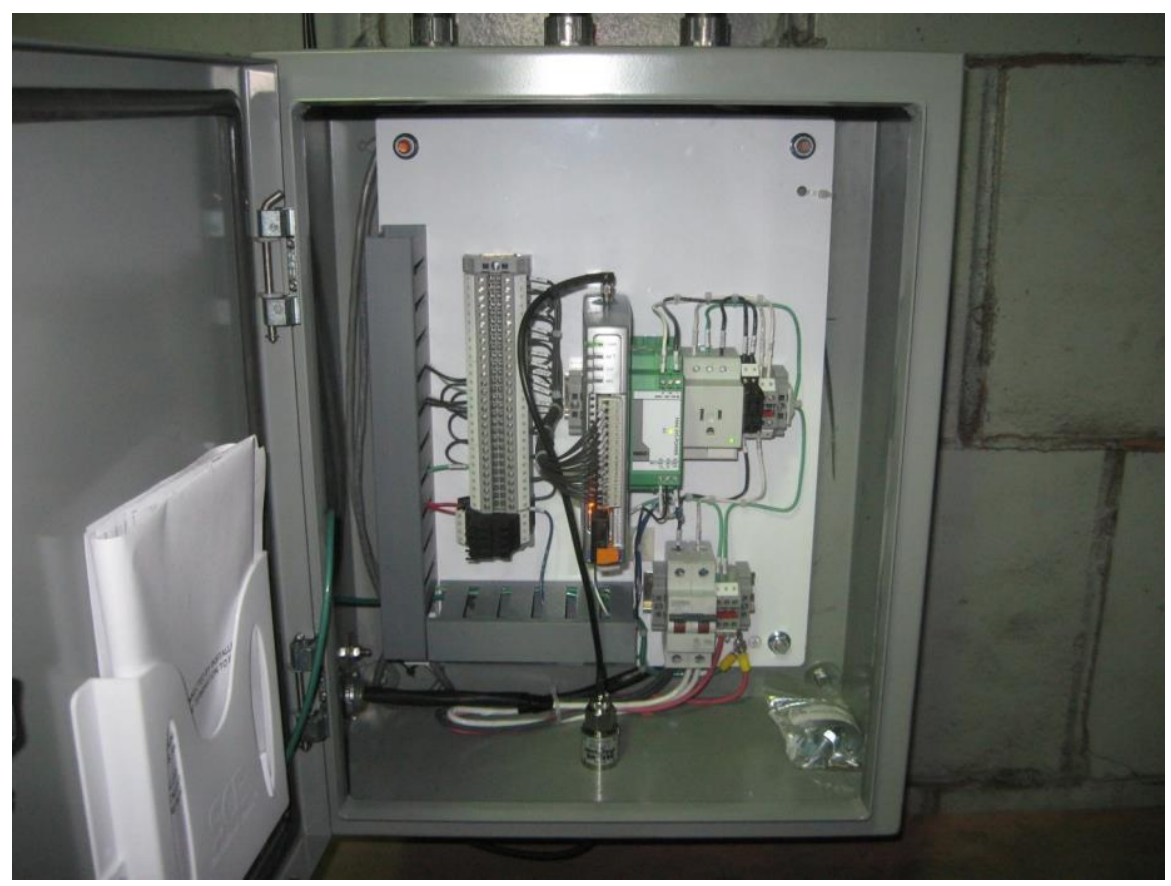

Photo W. Main Cabinet for Radio Unit for Preheater for Boiler \#3 in \#2 Powerhouse

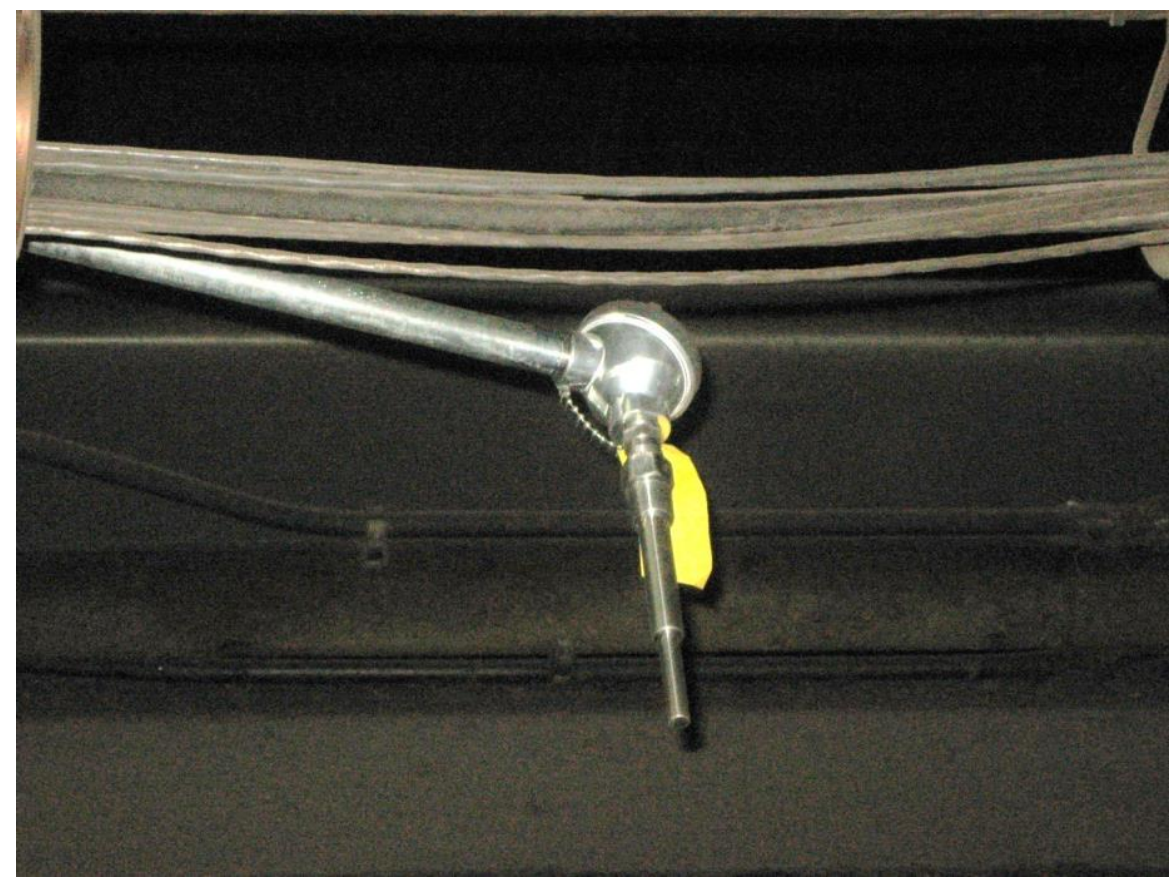

Photo X. Preheater Inlet Temperature Probe for Boiler \#3 in \#2 Powerhouse 


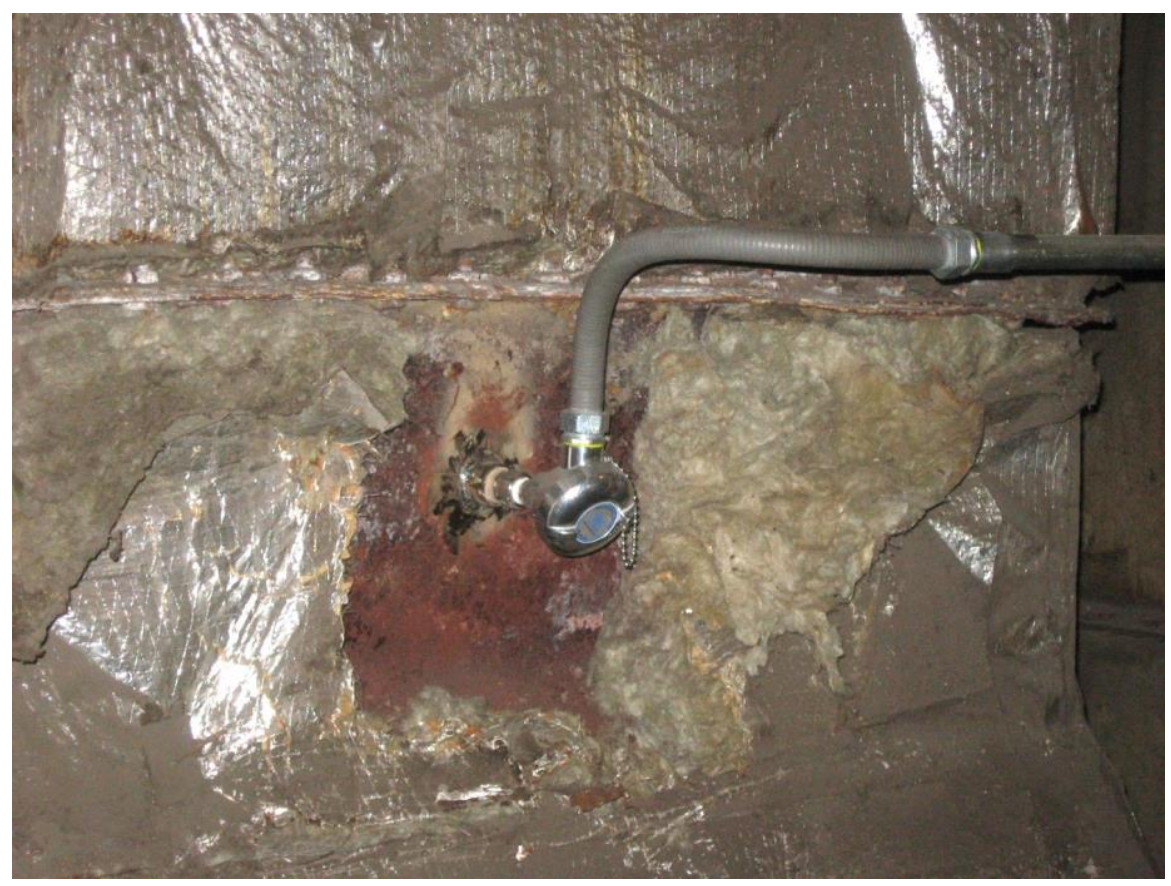

Photo Y. Preheater Outlet Temperature Probe for Boiler \#3 in \#2 Powerhouse 


\section{CMC-SC - RF SITE SURVEY REPORT (JUNE 2010) \\ CMC RF Site Survey \\ Conducted on July 28-29, 2010}

\section{PURPOSE/OBJECTIVES}

The purpose of this radio frequency (RF) survey is to empirically analyze the RF environment in the CMC Steel Plant, Cayce, SC. Three different frequency bands chosen mainly are 902$928 \mathrm{MHz}, 2.4-2.4835 \mathrm{GHz}$ and $5.725-5.875 \mathrm{GHz}$. These frequency bands correspond to the unlicensed Industrial, Scientific and Medical (ISM) bands, commonly used in current wireless networking technologies. The collected data will help understand the background interference and noise levels before the deployment of the desired wireless network and also help predict signal strength and related propagation issues.

\section{APPROACH}

All of the measurement equipment is characterized extensively for any spurious EM emissions. The measurement equipment that will be used for this test includes:

- Rhode \& Schwarz FSH3 spectrum analyzer

- Electro-Metrics EM-6105 wideband discone antenna

- $2.4 \mathrm{GHz} \& 5.8 \mathrm{GHz}$ Transceivers with omni-directional antennae

- Wide-band discone antenna

- $2.4 \mathrm{GHz}$ wireless transceivers

- Laptop computer

The purpose of this test is to scan for frequencies in the environment and related power levels residing in and around the Steel Mill to identify potential interference and noise sources. This survey is performed in accordance with IEEE 473 standard. The complete measurement takes 18 min. including saving of the data per each run. The test will be repeated at multiple locations identified as potential points of interest with respect to processes of interest during this deployment.

\section{TEST SETUP}

The Rhode \& Schwartz FSH3 spectrum analyzer is controlled by a laptop running LabView software. A customized script was used to scan the spectrum in four different bands for a total of $3 \mathrm{~min}$ per band. The bands are $30 \mathrm{MHz}$ to $500 \mathrm{MHz}, 500 \mathrm{MHz}$ to $1 \mathrm{GHz}, 1 \mathrm{GHz}$ to $2 \mathrm{GHz}$, and $2 \mathrm{GHz}$ to $3 \mathrm{GHz}$. This scan results in a complete scan from $150 \mathrm{KHz}$ to $3 \mathrm{GHz}$ over a $15-$ min scan window. The laptop records the frequency and power level at designated increments and records the maximum signal presented during the 3-min scan.

Simultaneously we used equipment to digitally record the signals in the CMC steel mill in timedomain to analyze potential sources of interference and noise generators. The equipment is capable of recording $2.68 \mathrm{~s}$ of modulated time-domain signal at $400 \mathrm{MSamples} / \mathrm{s}$. The recording 
is done in a fixed bandwidth of $130 \mathrm{MHz}$ with variable center frequency in each of the three above specified ISM band.

Graphs containing redundant information are omitted for clarity. Locations that do not permit carrying extensive equipment only have frequency sweeps of narrow bands of interest

\section{CONCLUSION}

- The 2.4GHz band has an average noise floor of $-70 \mathrm{dBm}$.

- The EAF-LMS facility has a periodic (order of $1 \mathrm{~ms}$ ) broadband noise source that raises the noise floor from $-70 \mathrm{dBm}$ to $-30 \mathrm{dBm}$.

- $\quad$ The $5.8 \mathrm{GHz}$ band is relatively clean with average noise floor of $-75 \mathrm{dBm}$

- The plots below provide the RF environment in detail

\section{Location 1: Bag House Main Fans}

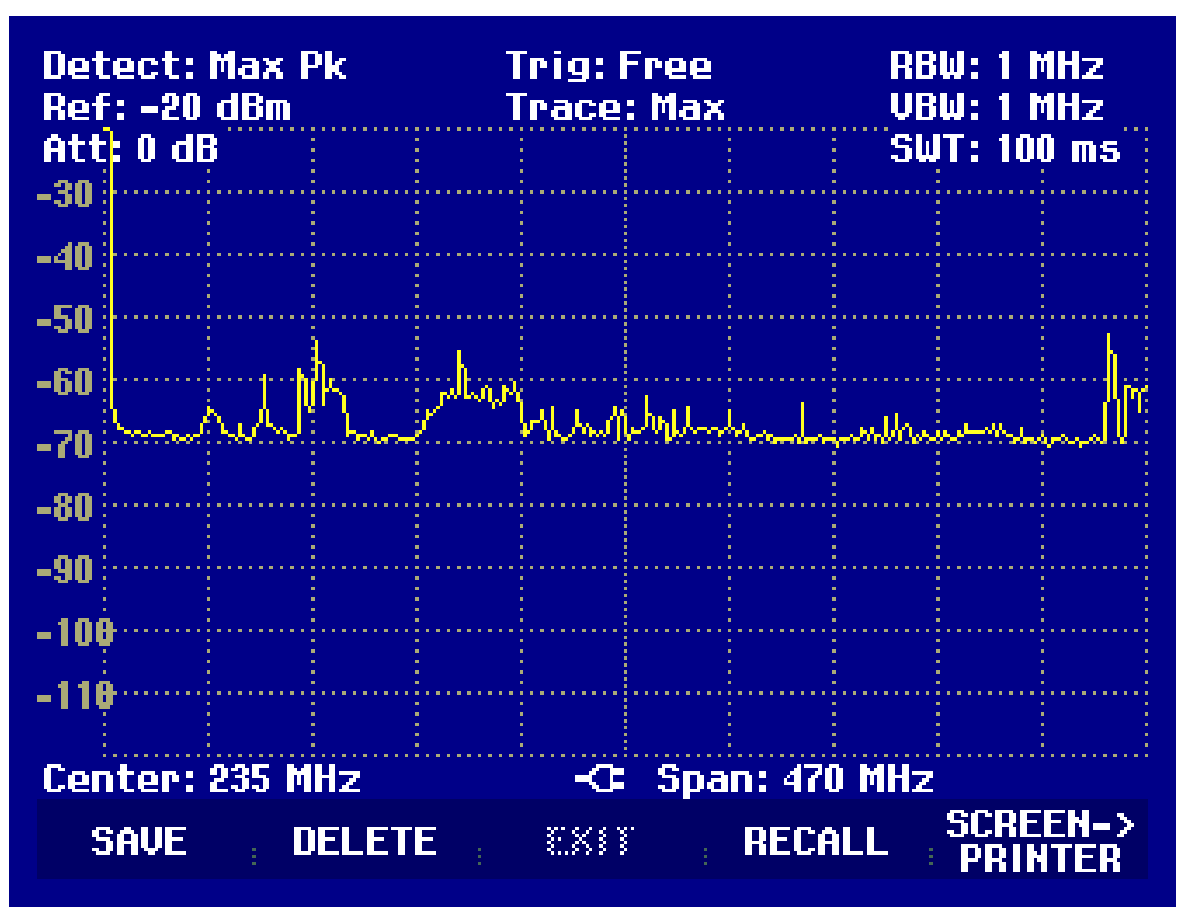

Figure 1: Spectrum centered at $235 \mathrm{MHz}$ and Span $470 \mathrm{MHz}$ 


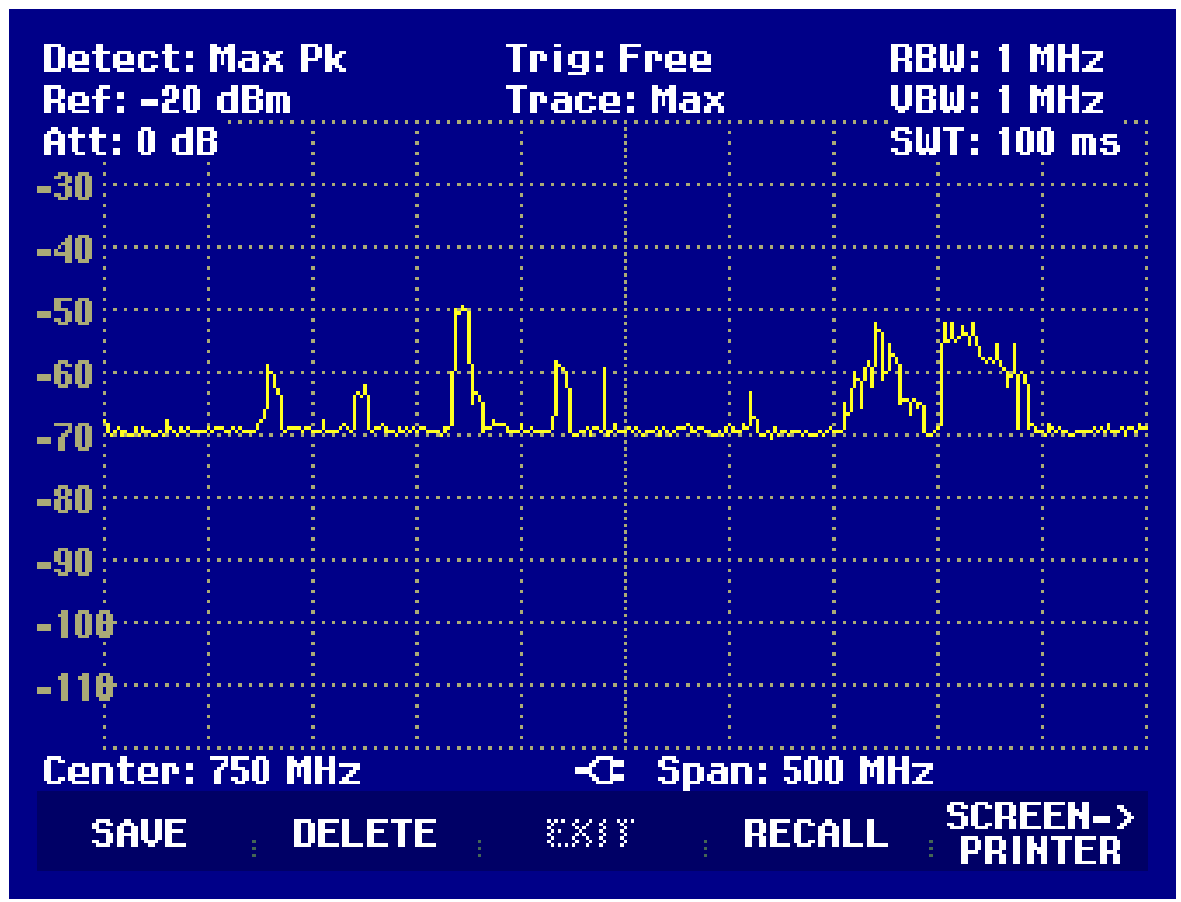

Figure 2: Spectrum centered at $750 \mathrm{MHz}$ and Span $500 \mathrm{MHz}$

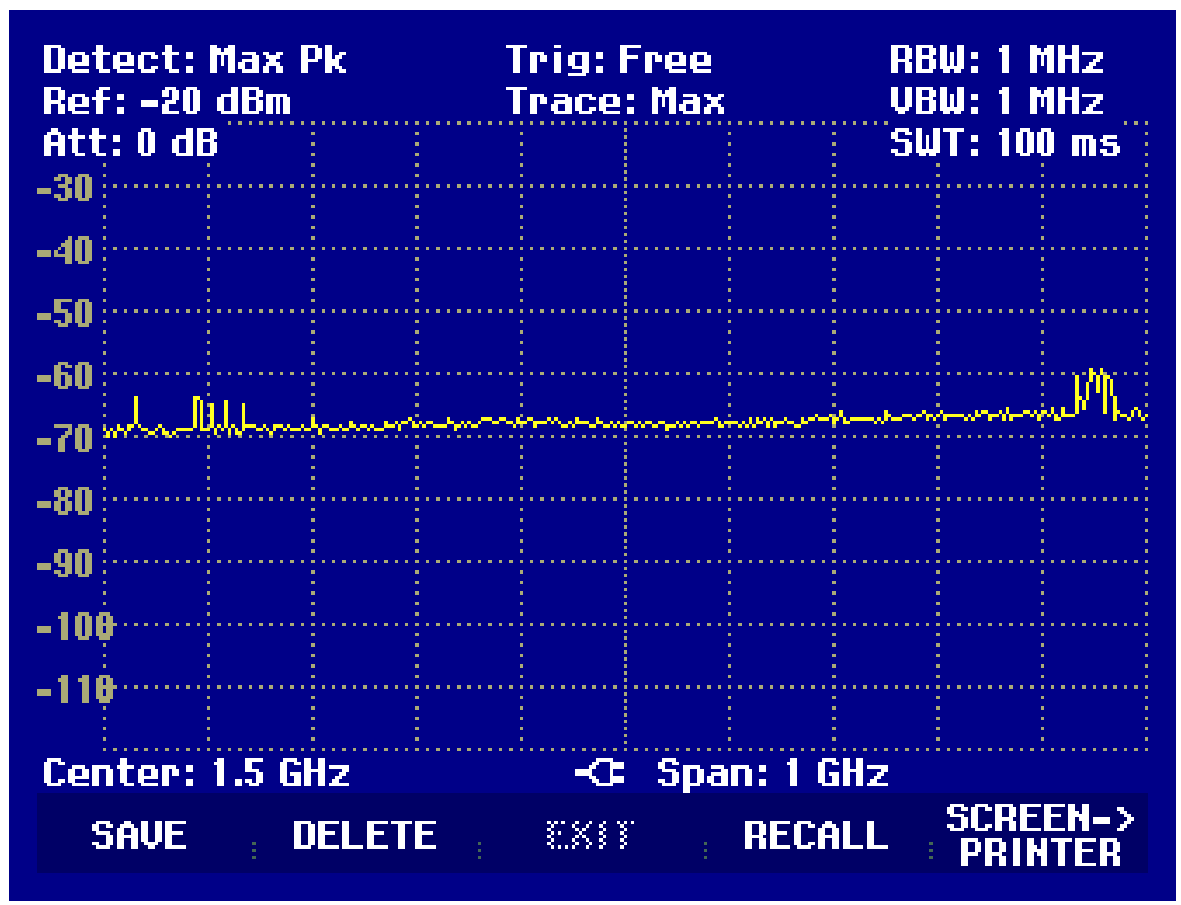

Figure 3: Spectrum centered at $1.5 \mathrm{GHz}$ and Span $1 \mathrm{GHz}$ 


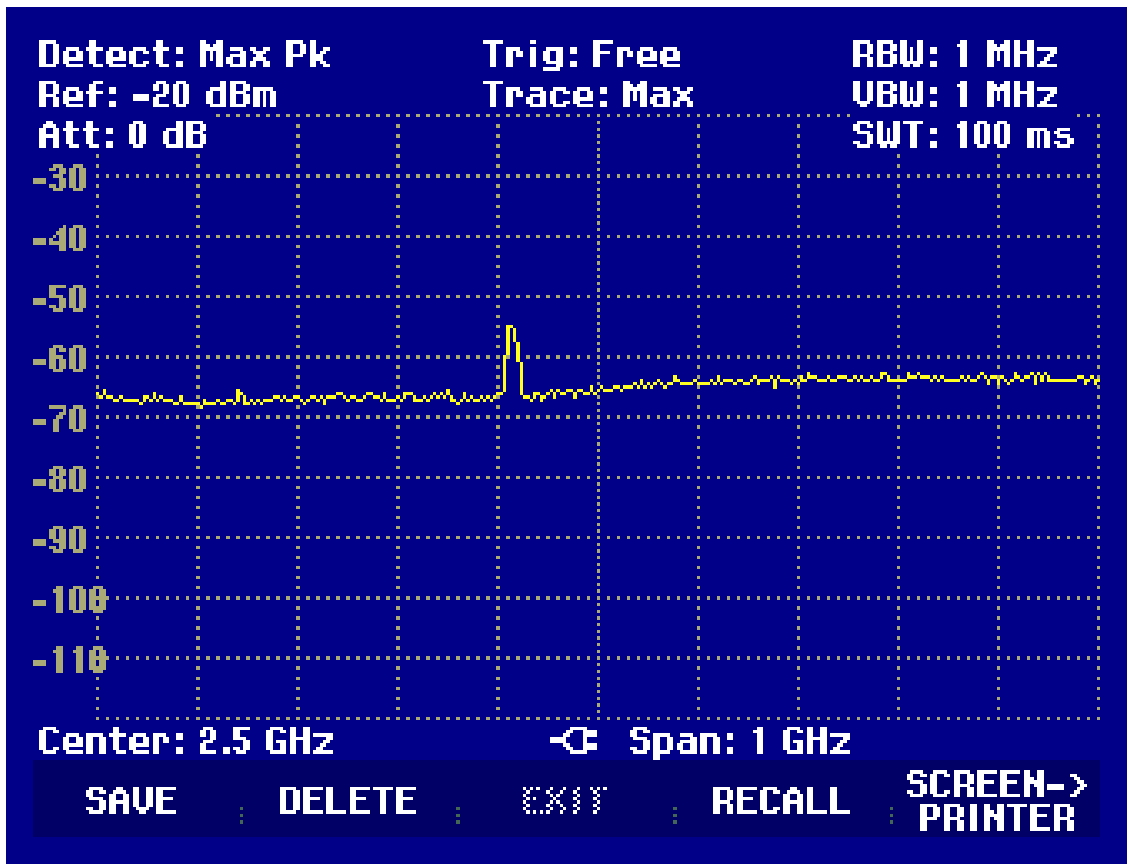

Figure 4: Spectrum centered at $2.5 \mathrm{GHz}$ and Span $1 \mathrm{GHz}$

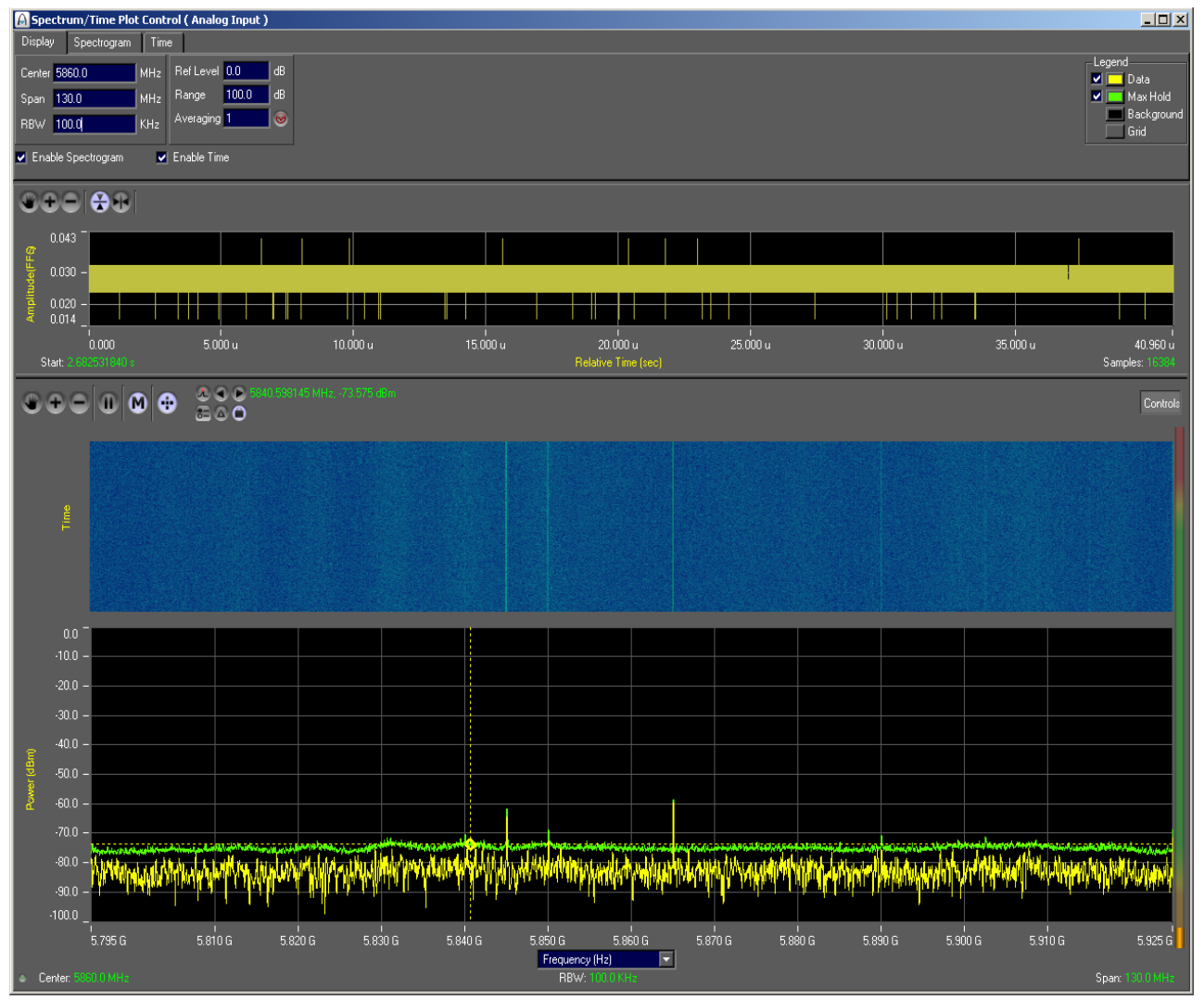

Figure 5: Spectrum centered at 5860GHz and Span 130MHz (Time \& Frequency Domain) 
Location 2: EAF-LMS

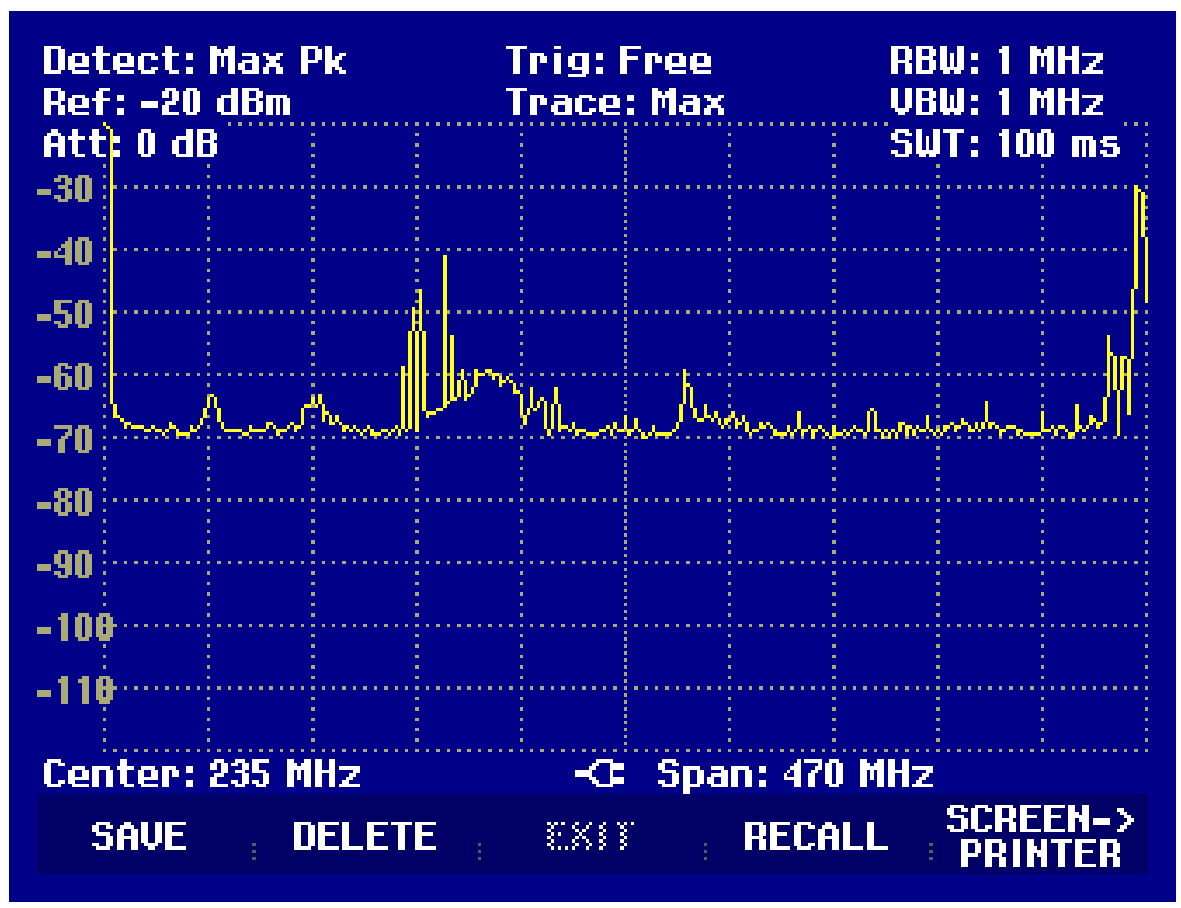

Figure 6a: Spectrum centered at $235 \mathrm{MHz}$ and Span $470 \mathrm{MHz}$

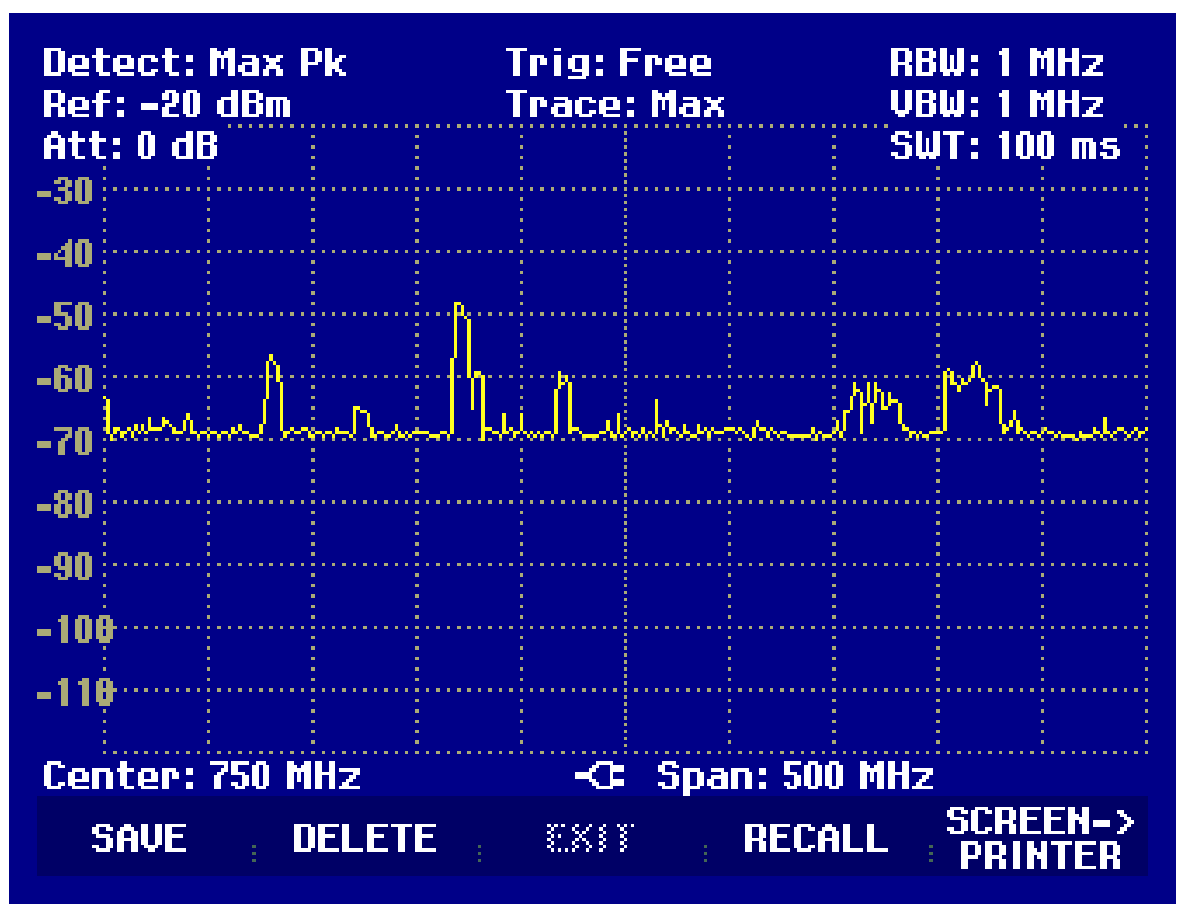

Figure 6b: Spectrum centered at $750 \mathrm{MHz}$ and Span $500 \mathrm{MHz}$ 


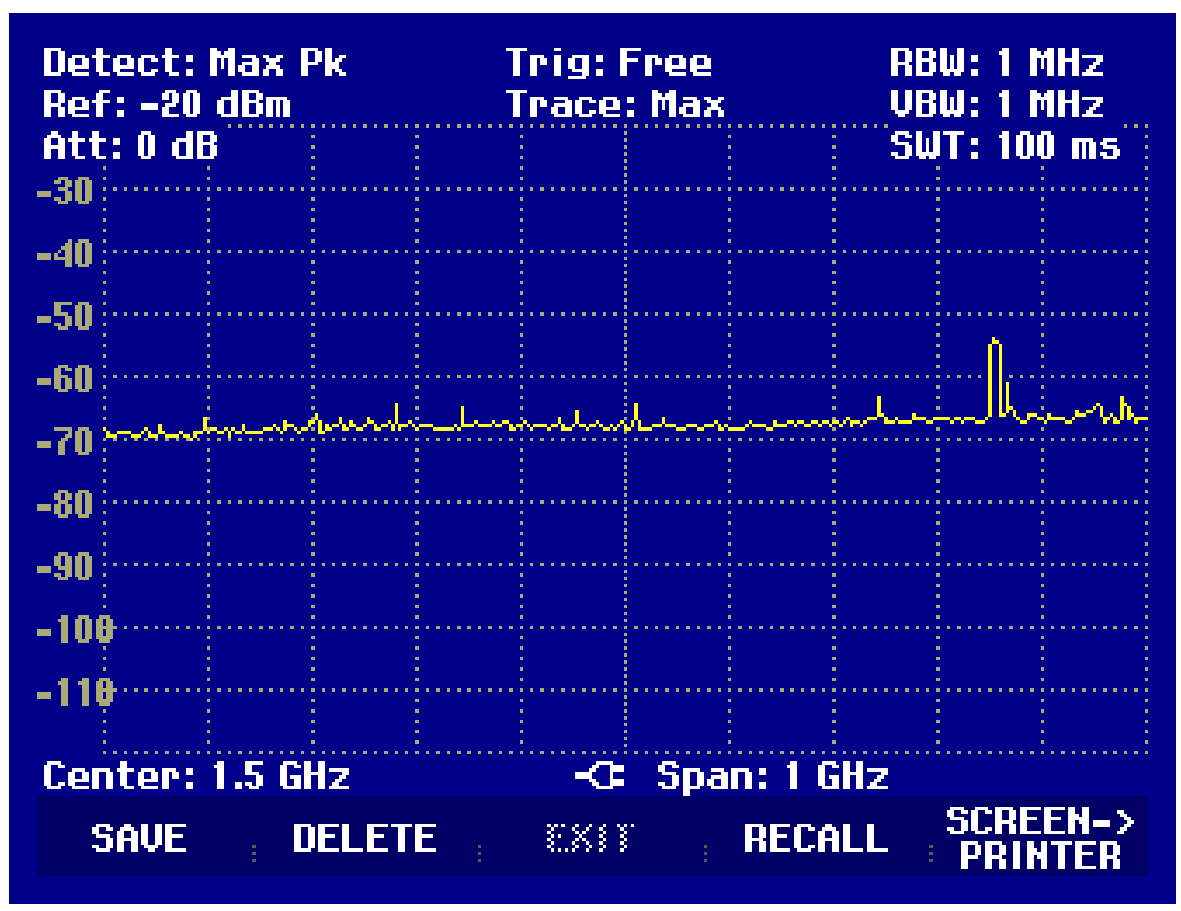

Figure 7: Spectrum centered at $1.5 \mathrm{GHz}$ and Span $1 \mathrm{GHz}$

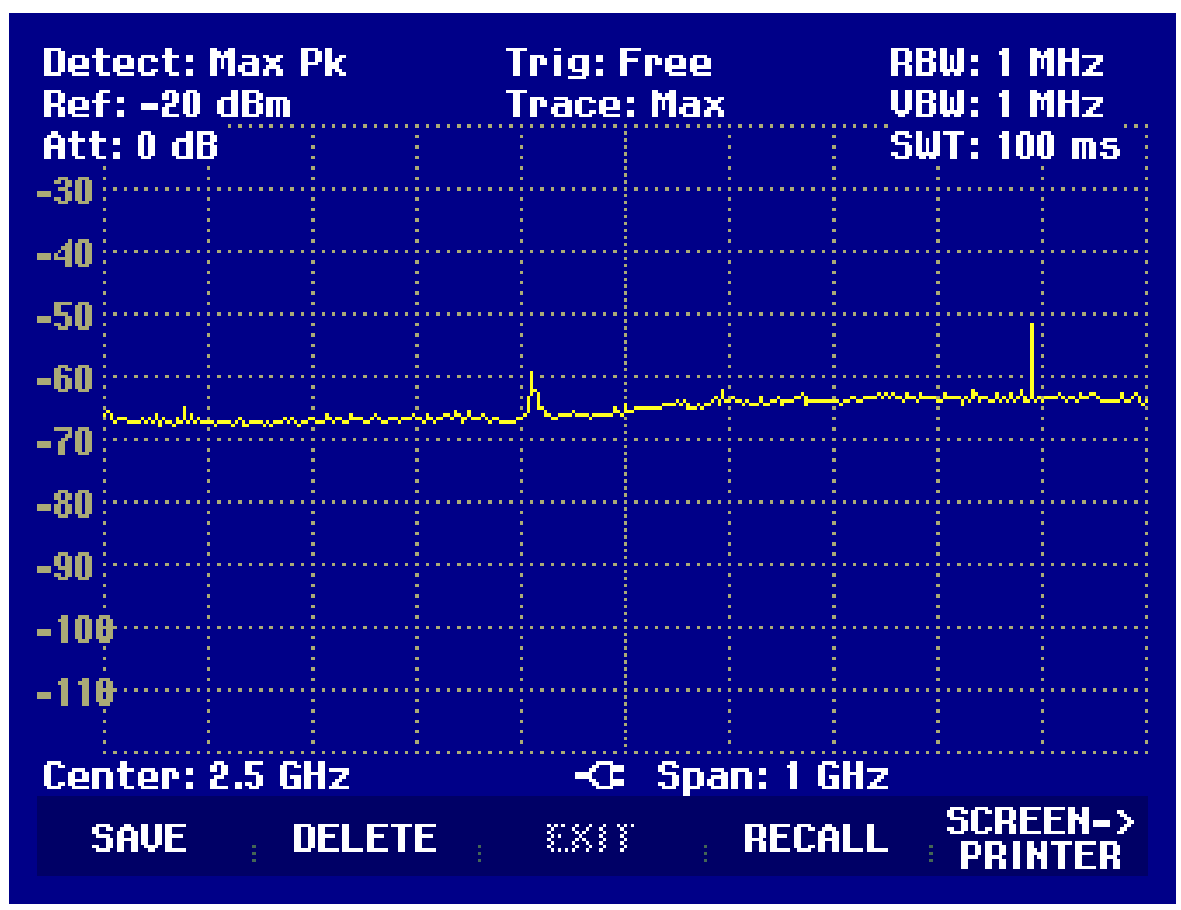

Figure 8: Spectrum centered at $2.5 \mathrm{GHz}$ and Span $1 \mathrm{GHz}$ 


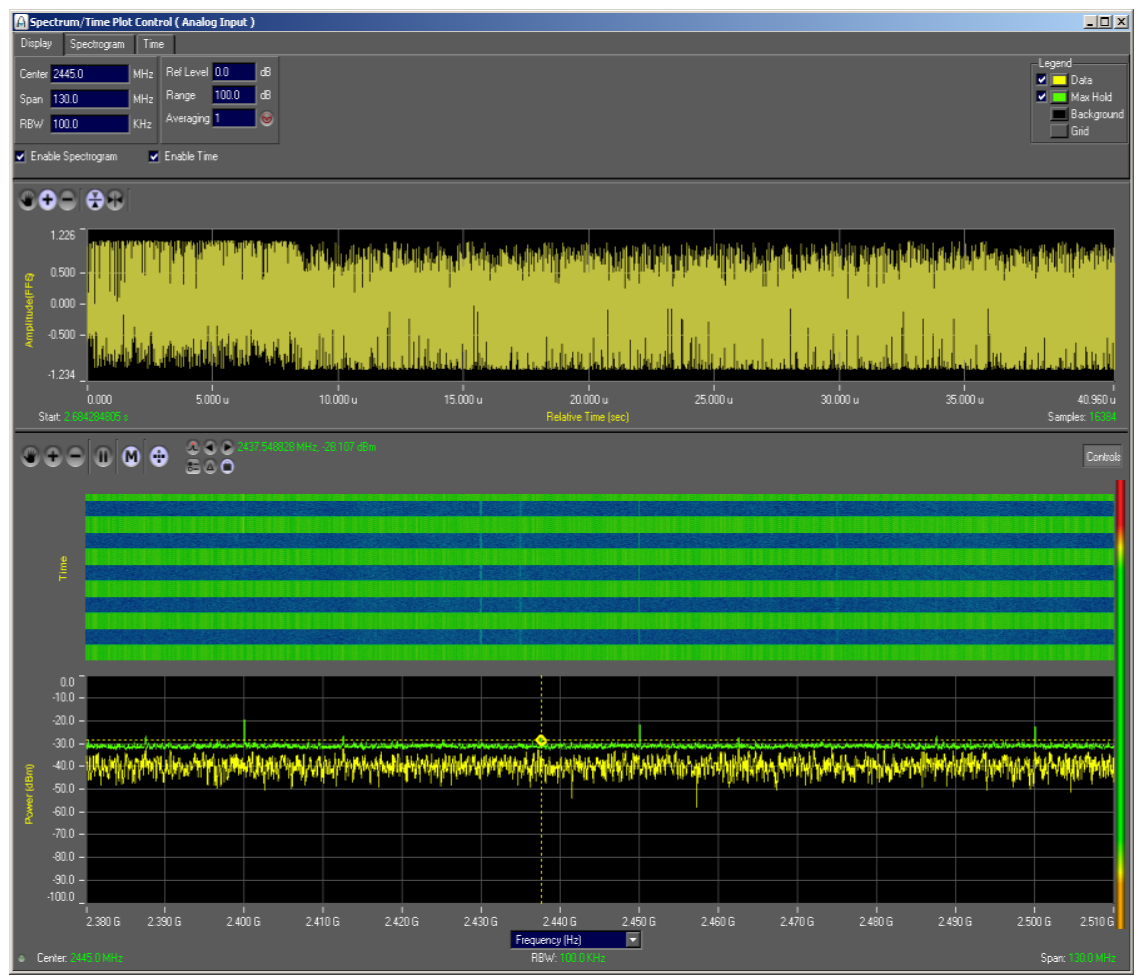

Figure 9: Spectrum centered at 2445MHz and span 130MHz (Time/Frequency Domain)

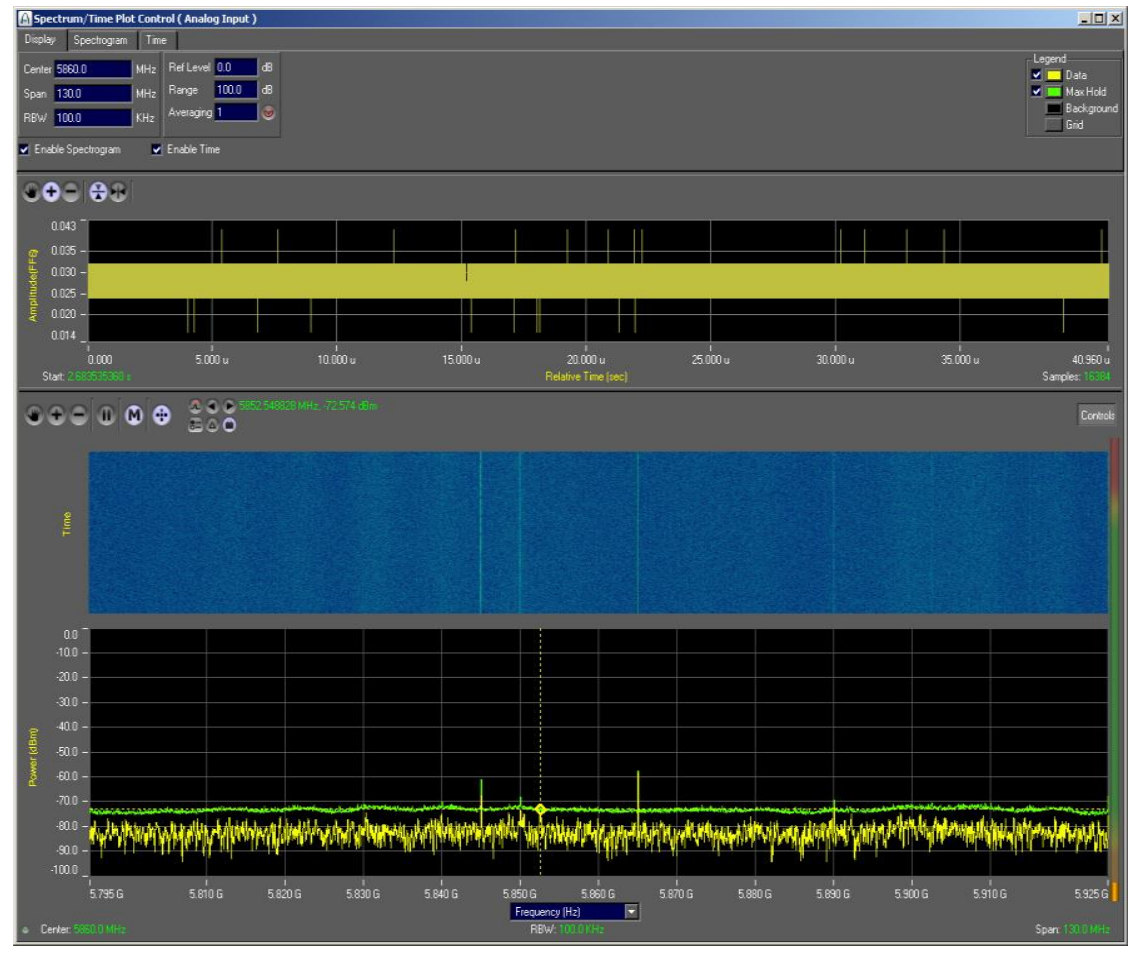

Figure 10: Spectrum centered at 5860MHz and span 130MHz (Time/Frequency Domain) 
Location 3: Scrap West Side

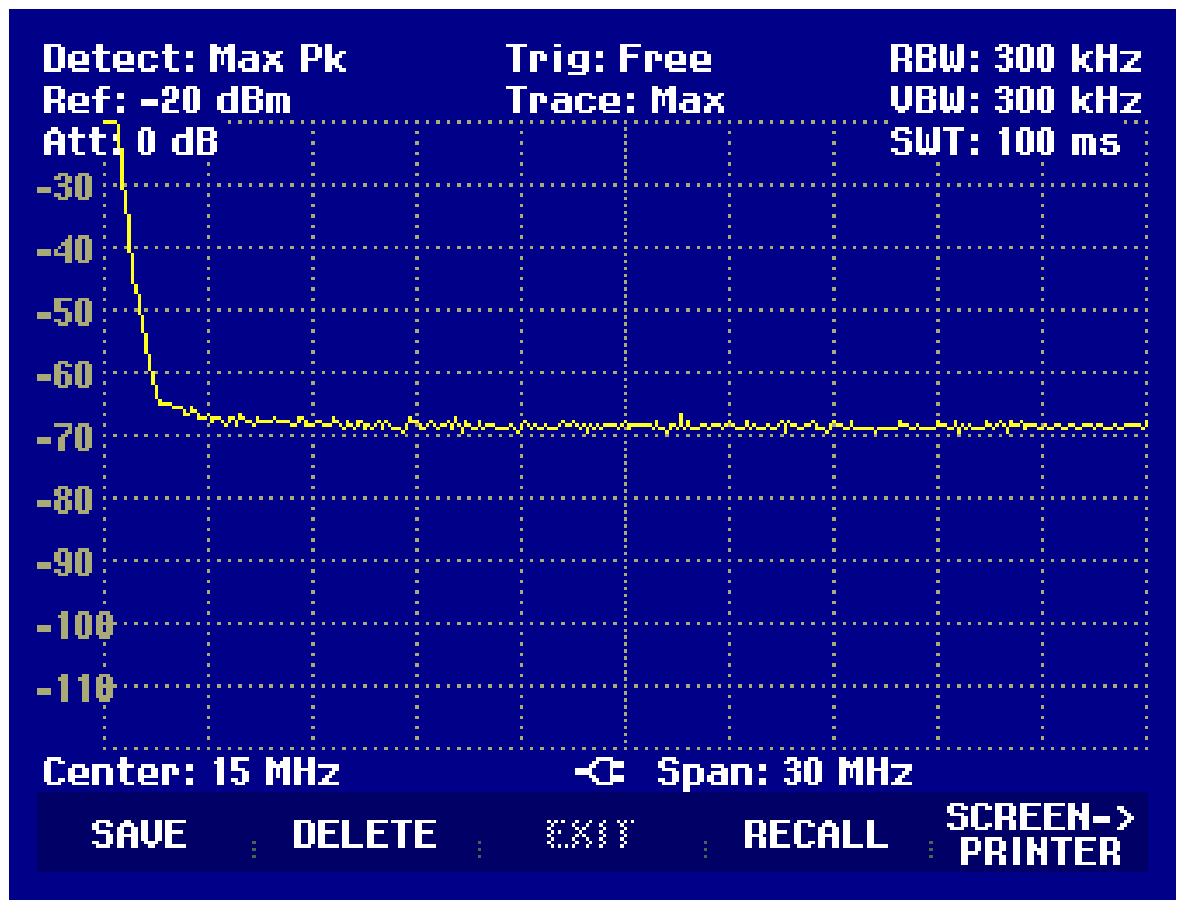

Figure 11: Spectrum centered at $15 \mathrm{MHz}$ and span $30 \mathrm{MHz}$

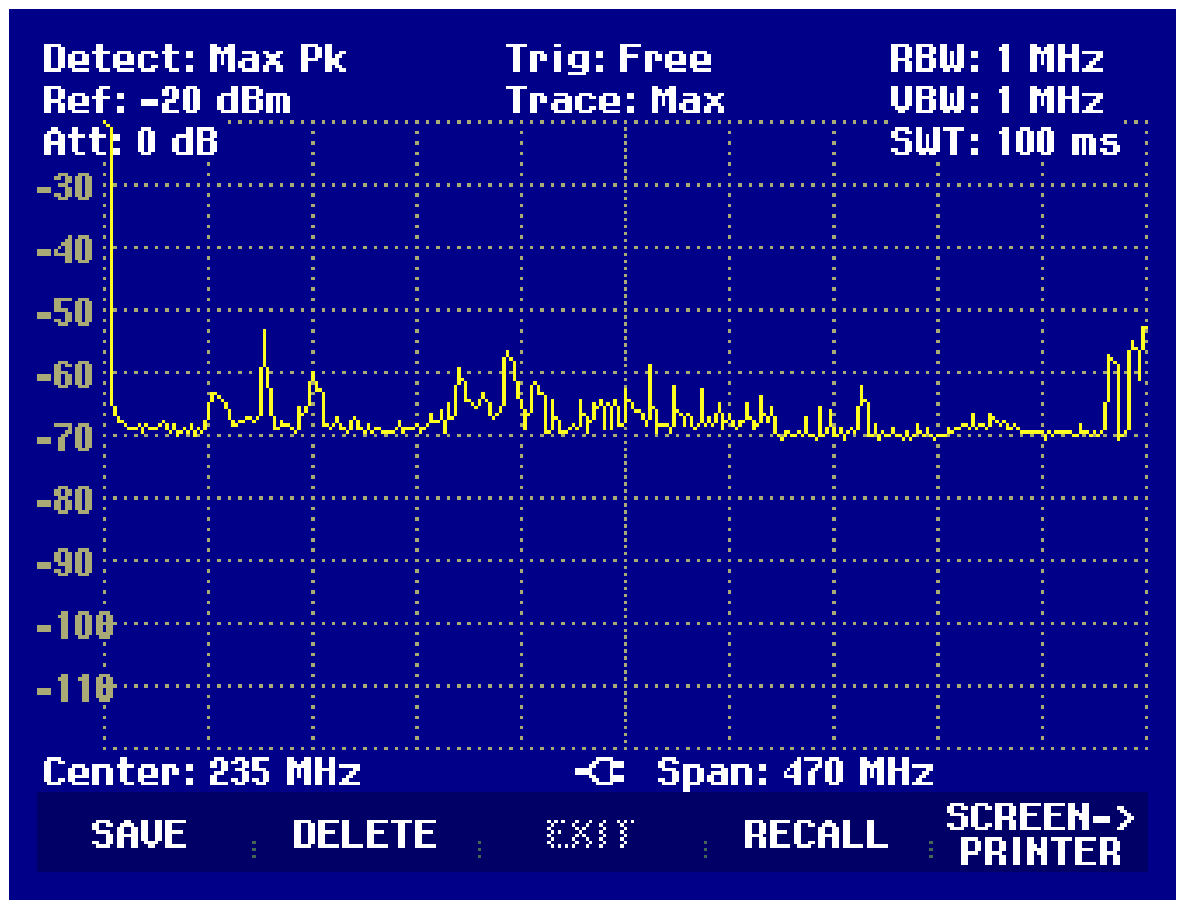

Figure 12: Spectrum centered at $235 \mathrm{MHz}$ and span $470 \mathrm{MHz}$ 


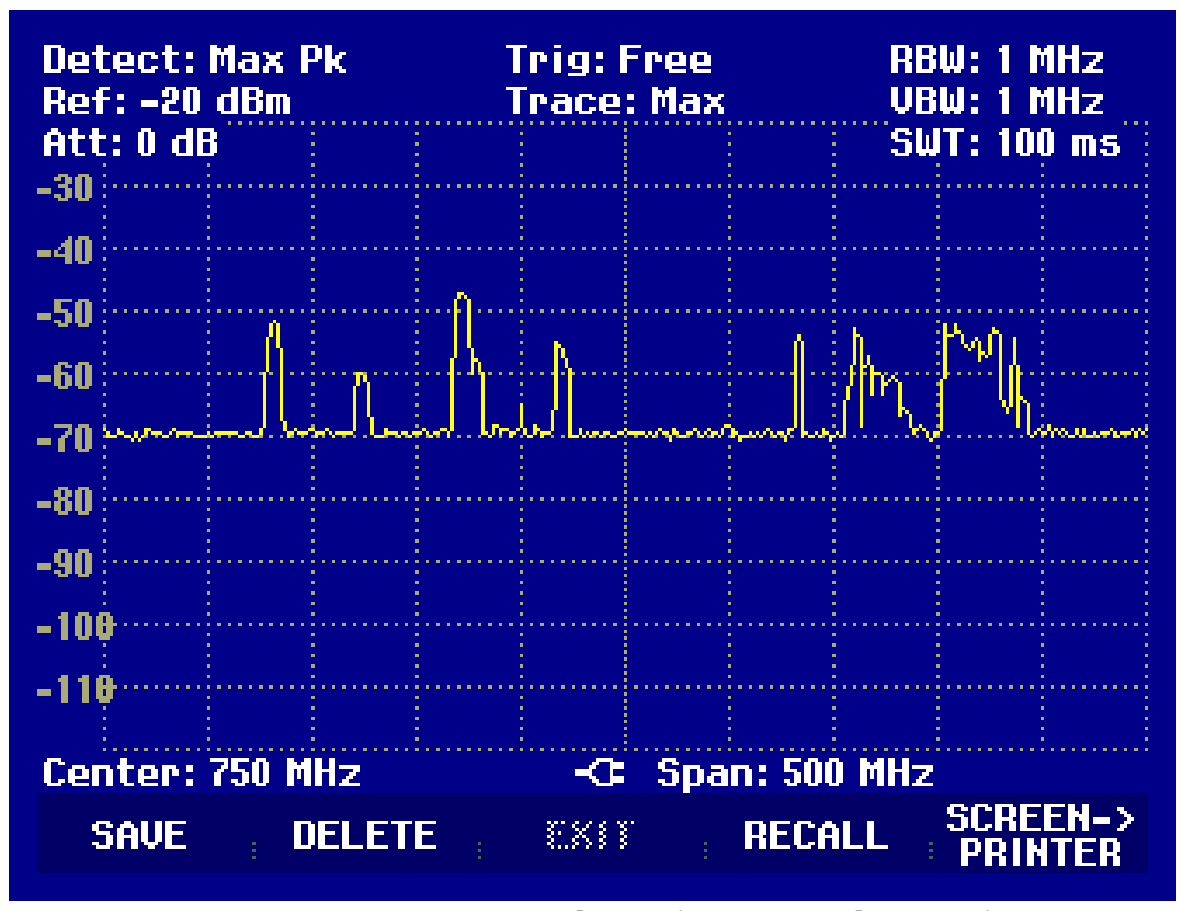

Figure 13: Spectrum centered at $750 \mathrm{MHz}$ and span $500 \mathrm{MHz}$

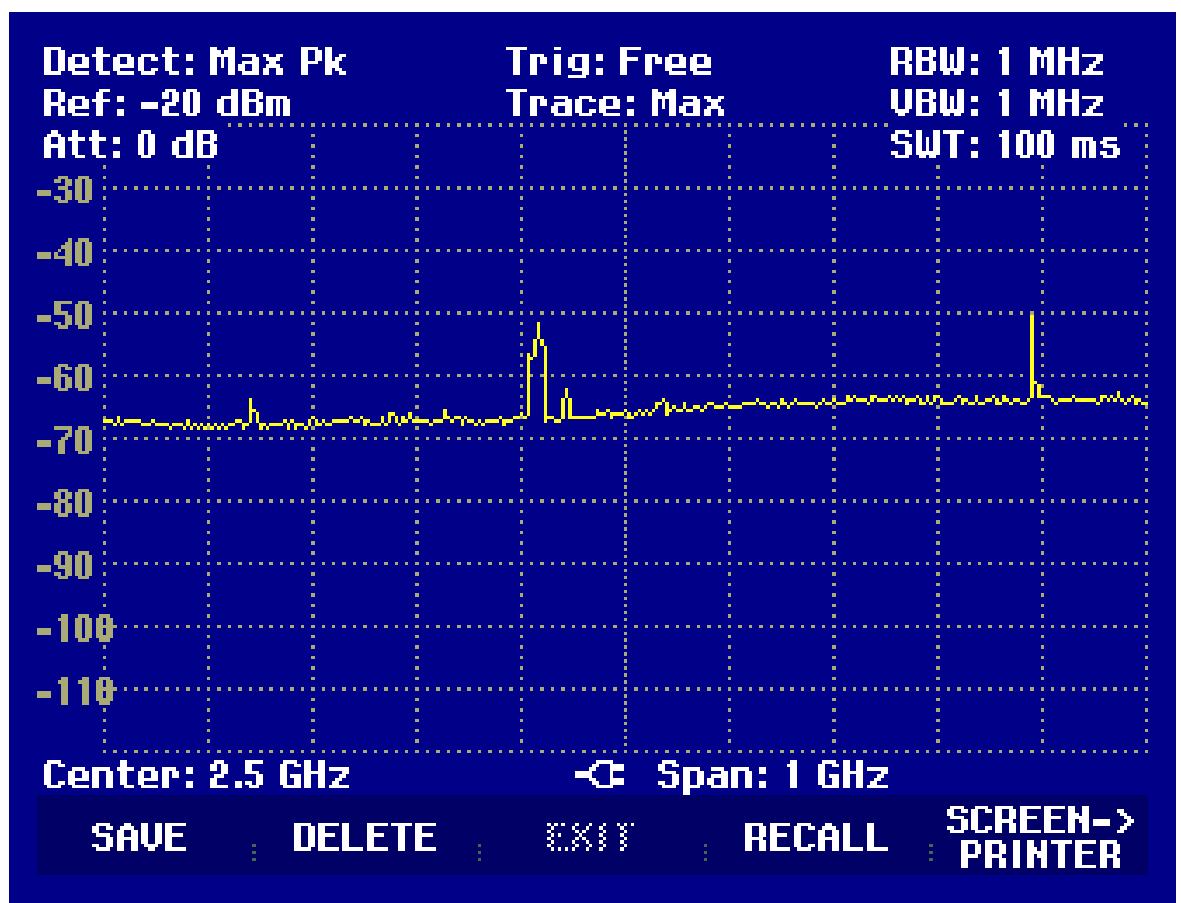

Figure 14: Spectrum centered at $2.5 \mathrm{GHz}$ and span $1 \mathrm{GHz}$ 


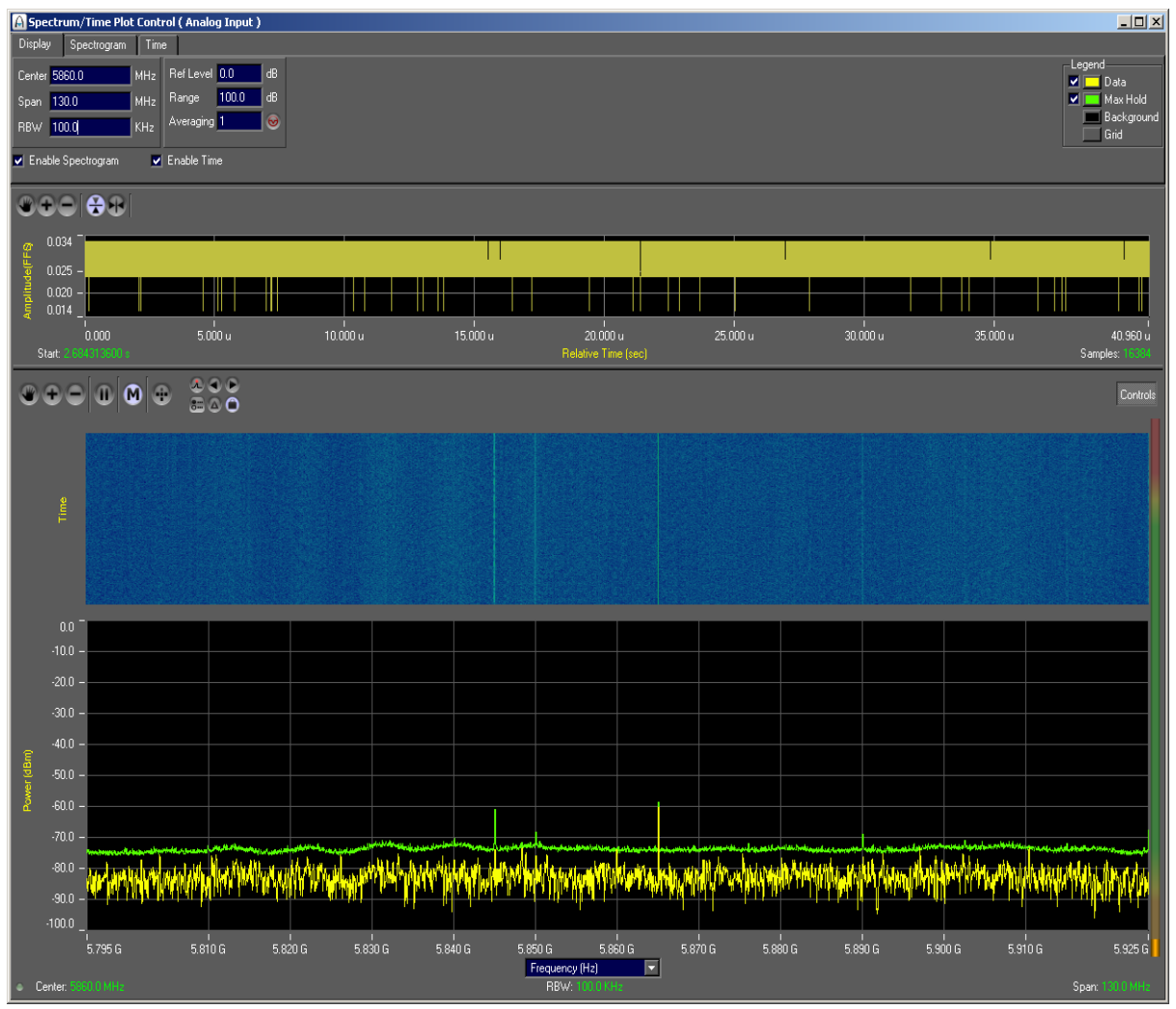

Figure 15: Spectrum centered at 5860MHz and span 130MHz (Time/Frequency Domain)

\section{Location 4: Billet Storage}

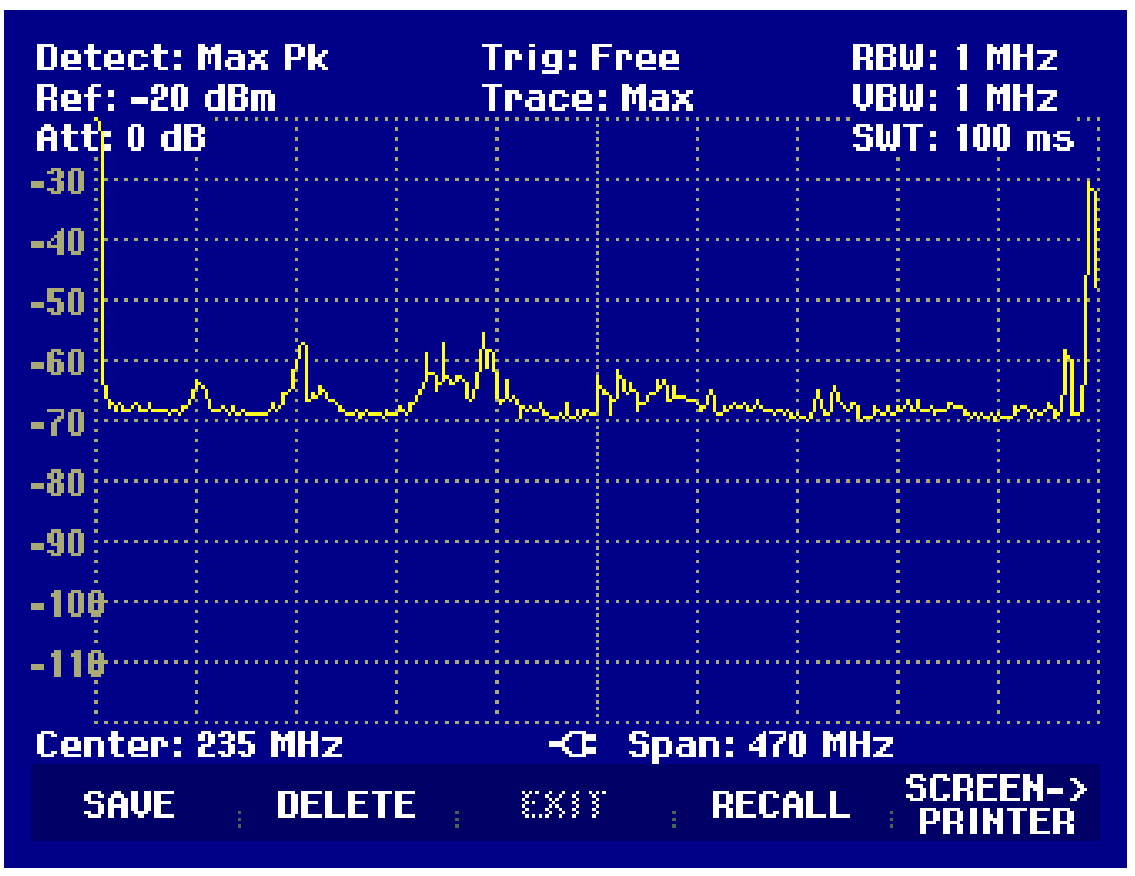

Figure 16: Spectrum centered at $235 \mathrm{MHz}$ and Span $470 \mathrm{MHz}$ 


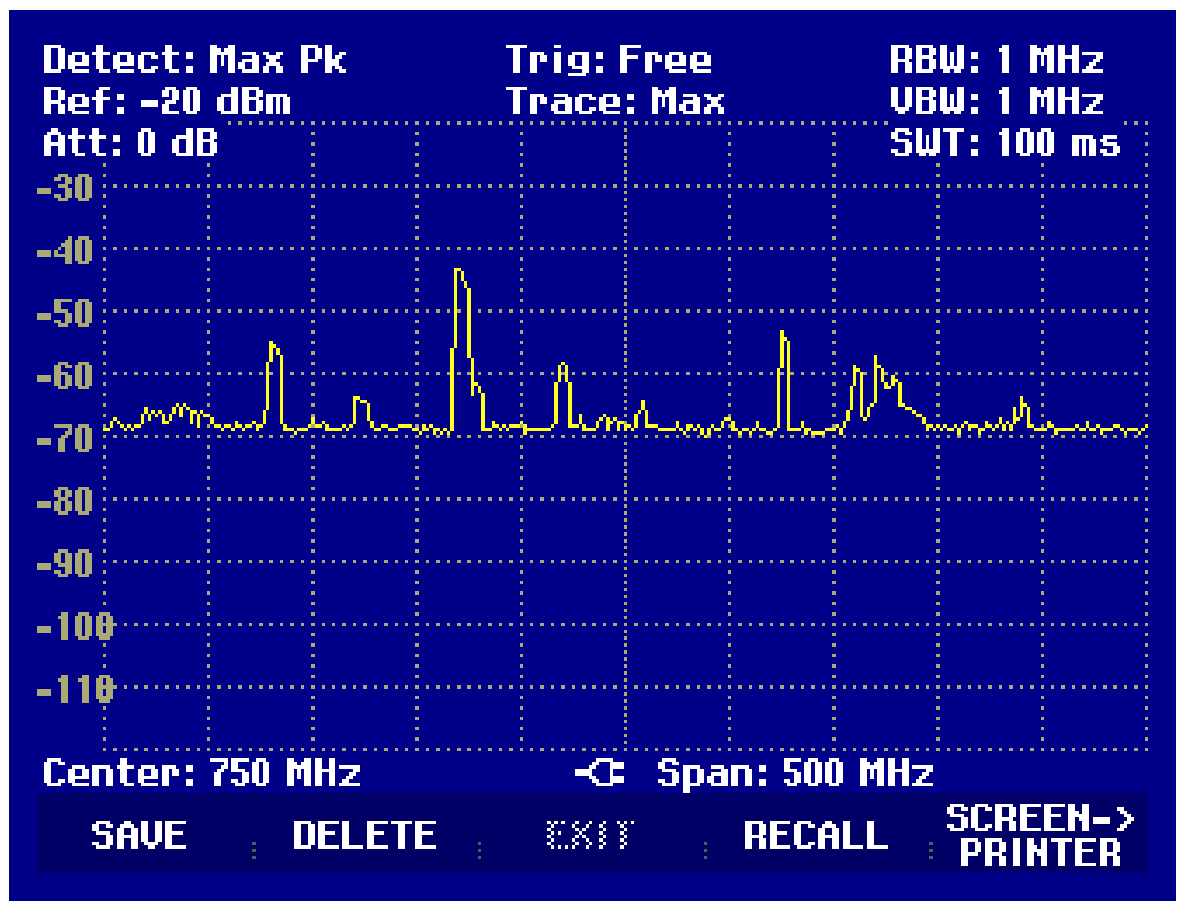

Figure 17: Spectrum centered at $750 \mathrm{MHz}$ and Span $500 \mathrm{MHz}$

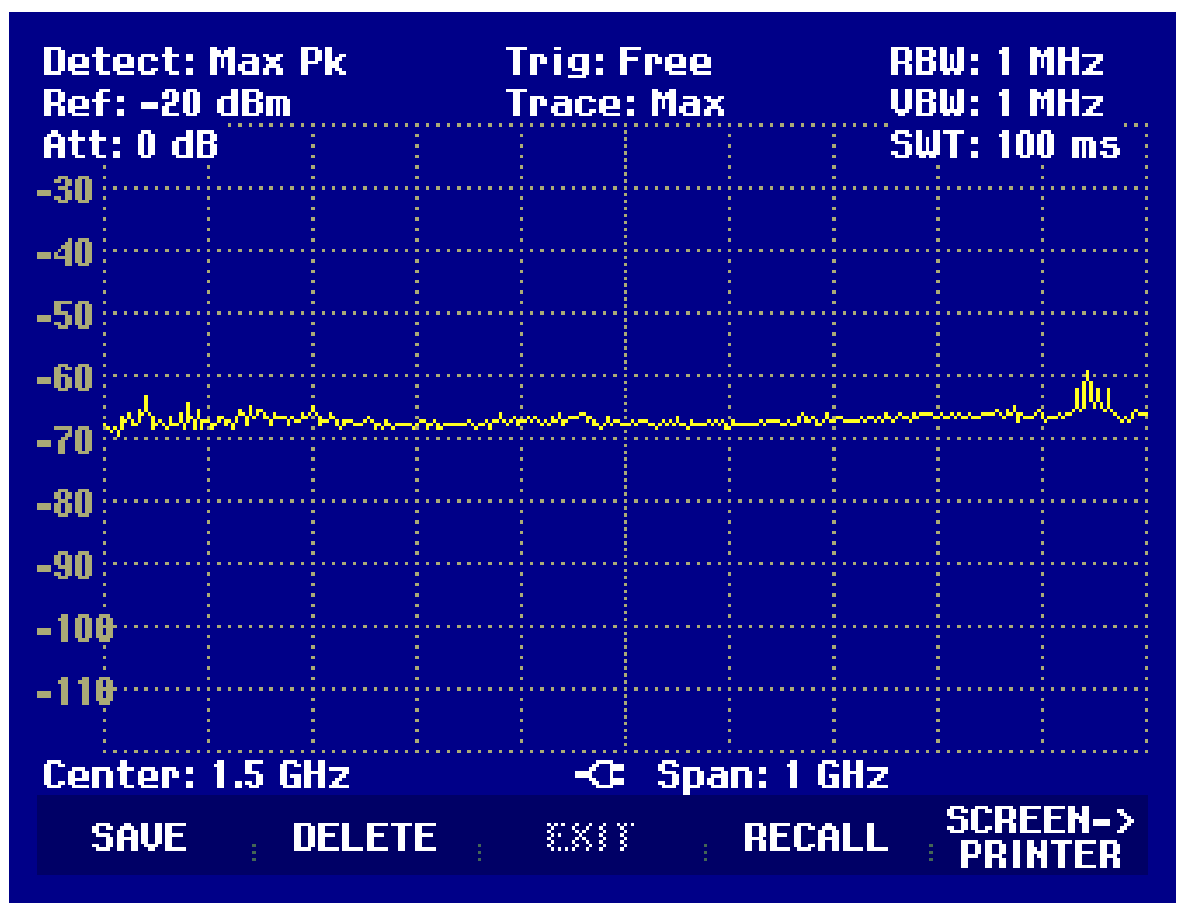

Figure 18: Spectrum centered at $1.5 \mathrm{GHz}$ and Span $1 \mathrm{GHz}$ 


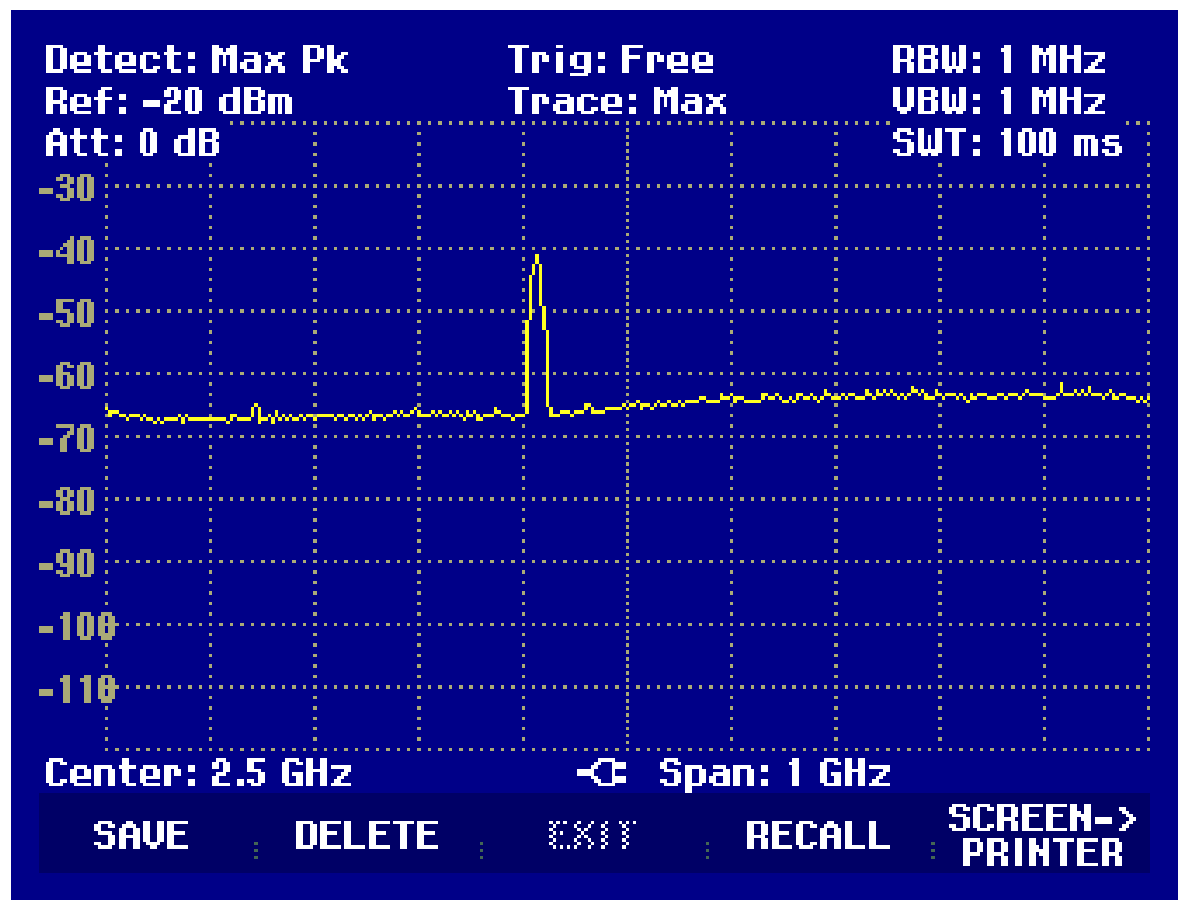

Figure 19: Spectrum centered at $2.5 \mathrm{MHz}$ and Span $1 \mathrm{GHz}$

Location 5: LMS Pulpit

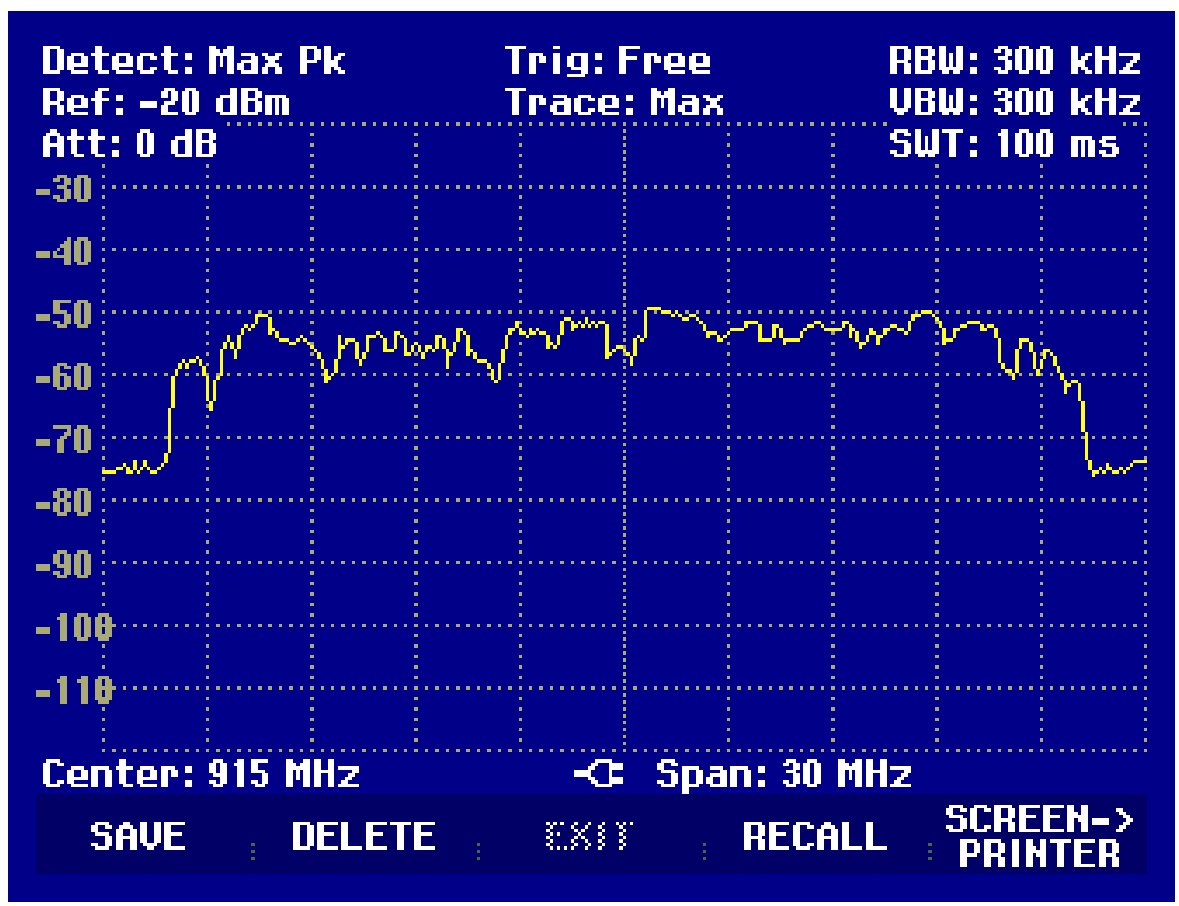

Figure 20: Spectrum centered at $915 \mathrm{MHz}$ and Span $30 \mathrm{MHz}$ 


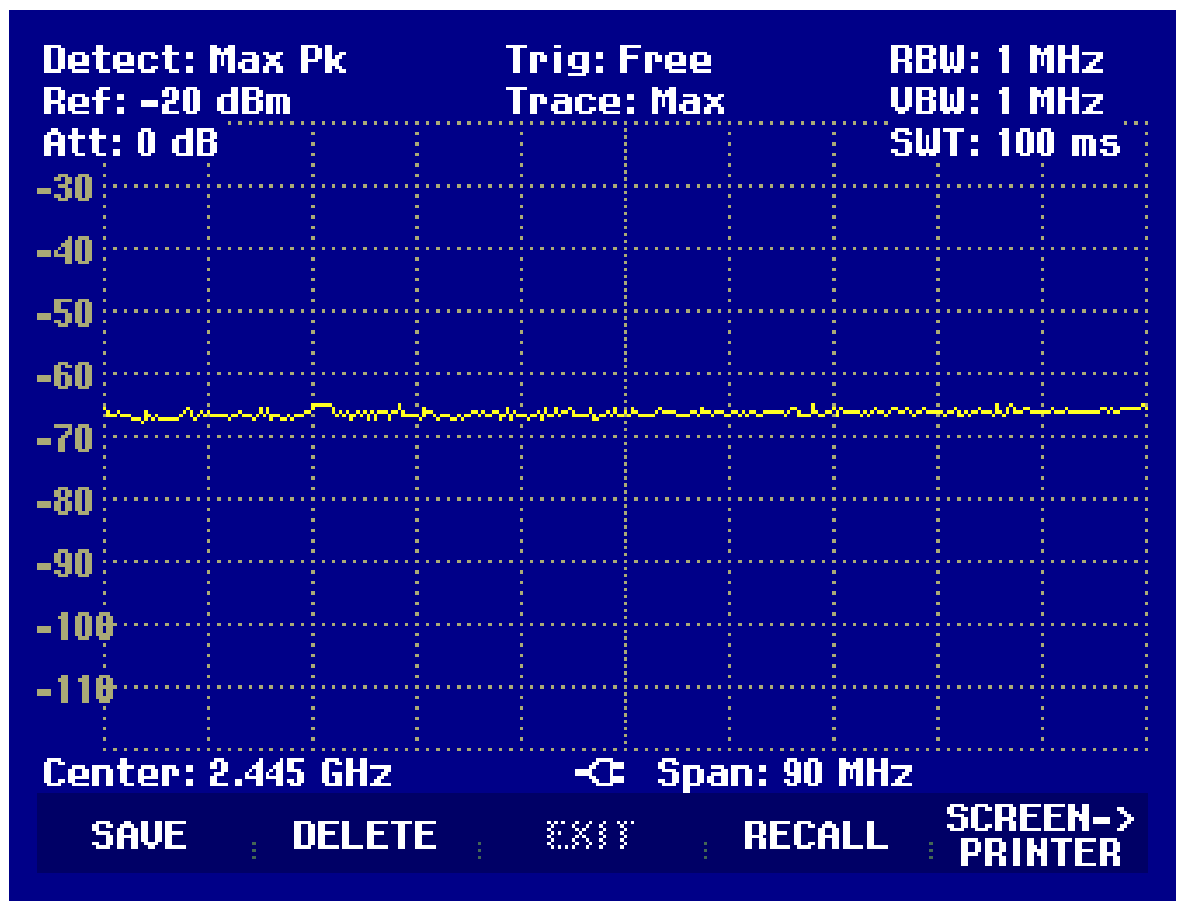

Figure 21: Spectrum centered at $2445 \mathrm{MHz}$ and Span $90 \mathrm{MHz}$

\section{Location 6: Caster Pulpit}

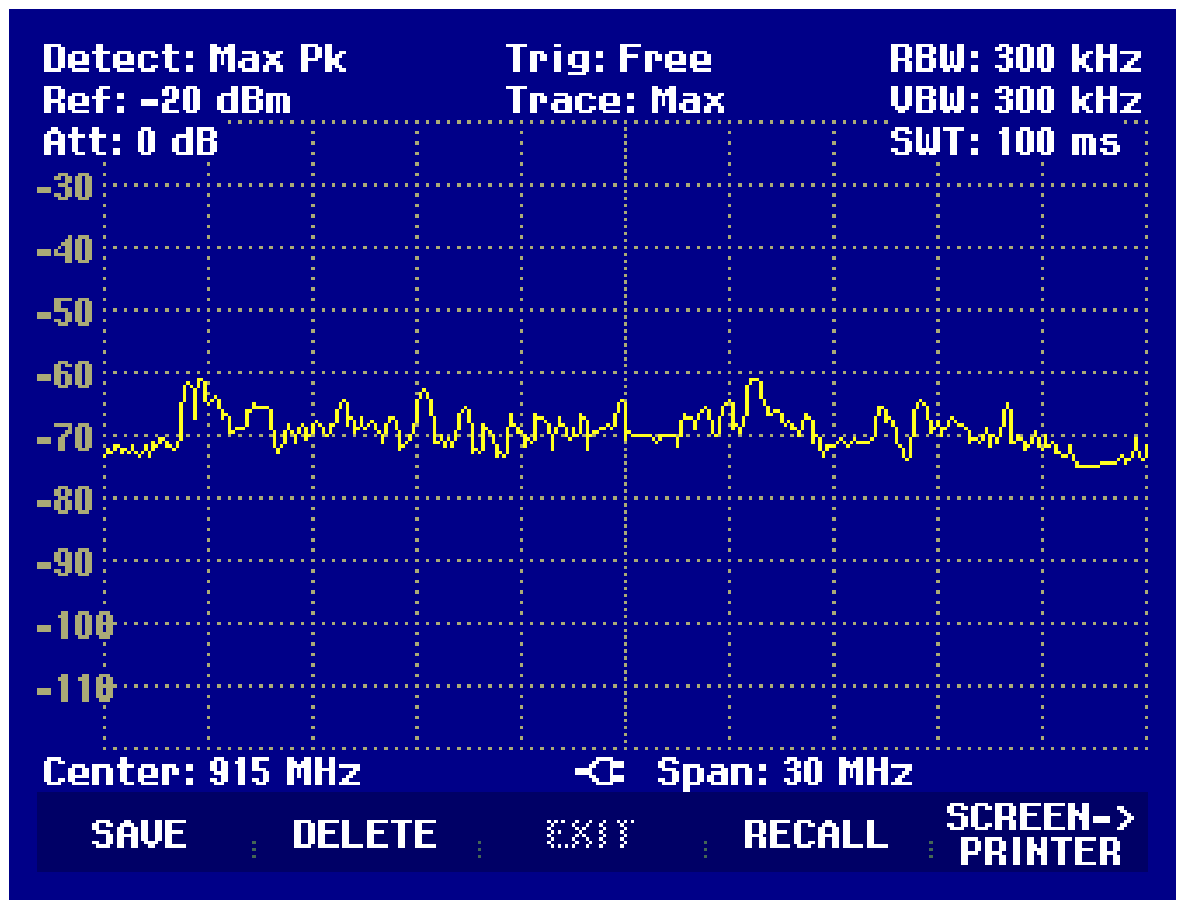

Figure 22: Spectrum centered at $915 \mathrm{MHz}$ and Span $30 \mathrm{MHz}$ 


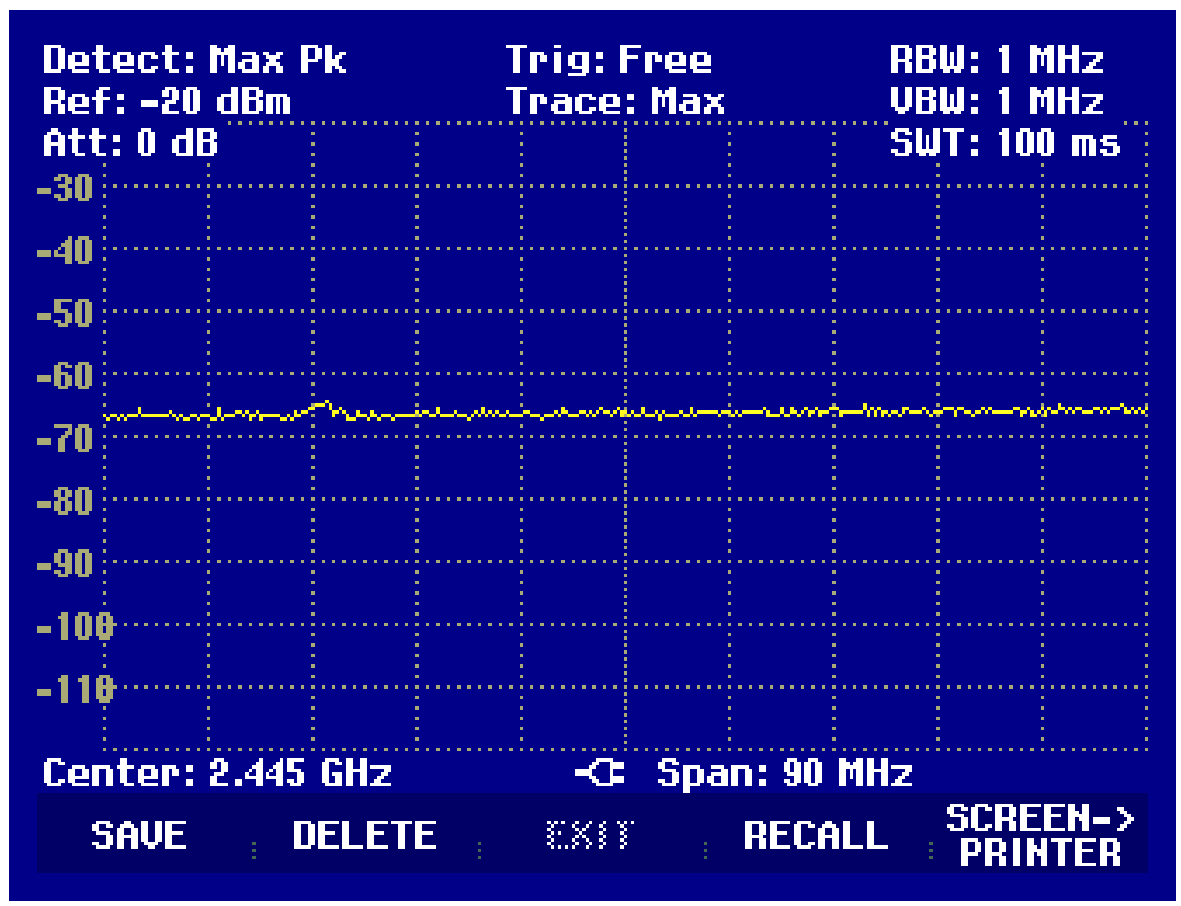

Figure 23: Spectrum centered at $2445 \mathrm{MHz}$ and Span $90 \mathrm{MHz}$

Location 7: Cooling Bay

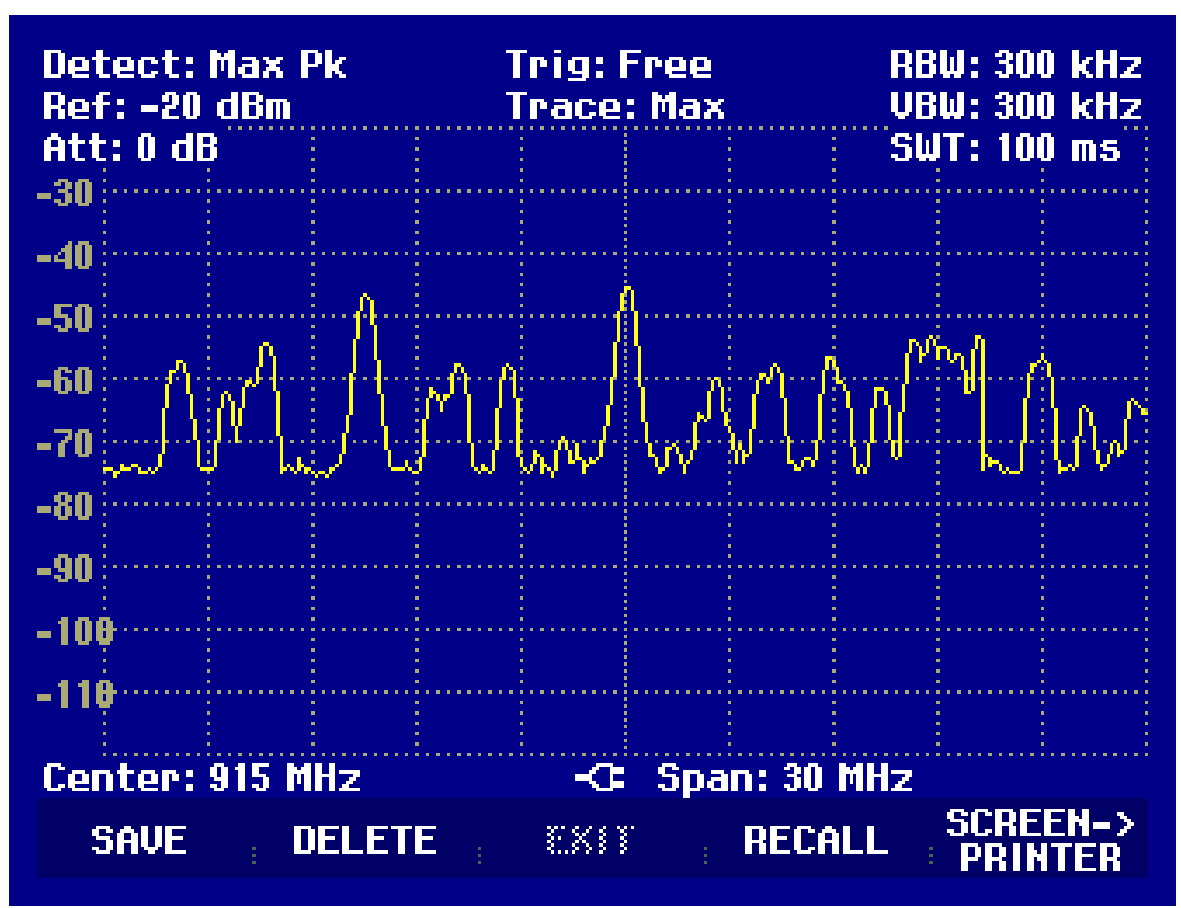

Figure 24: Spectrum centered at $915 \mathrm{MHz}$ and Span $30 \mathrm{MHz}$ 


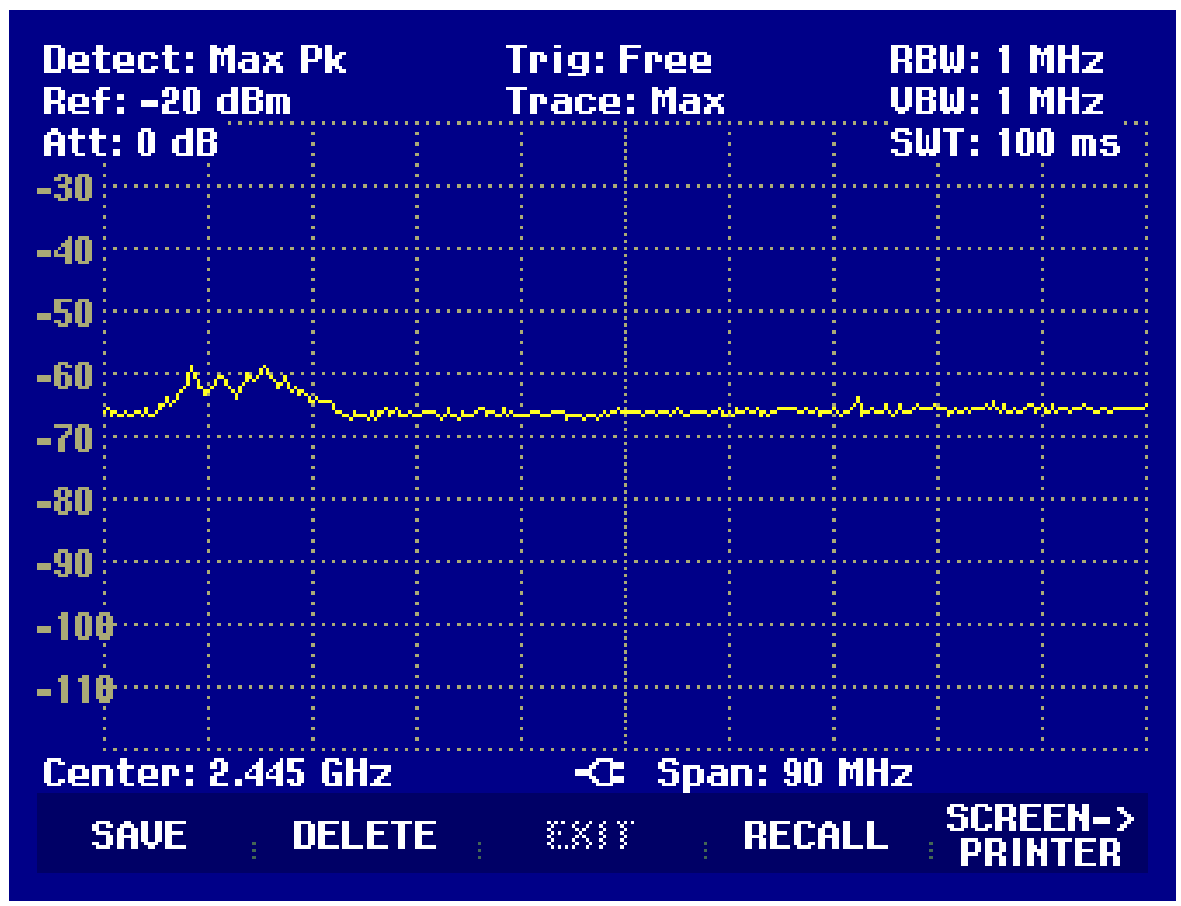

Figure 25: Spectrum centered at $2445 \mathrm{MHz}$ and Span $90 \mathrm{MHz}$

\section{Location 8: Rolling Mill}

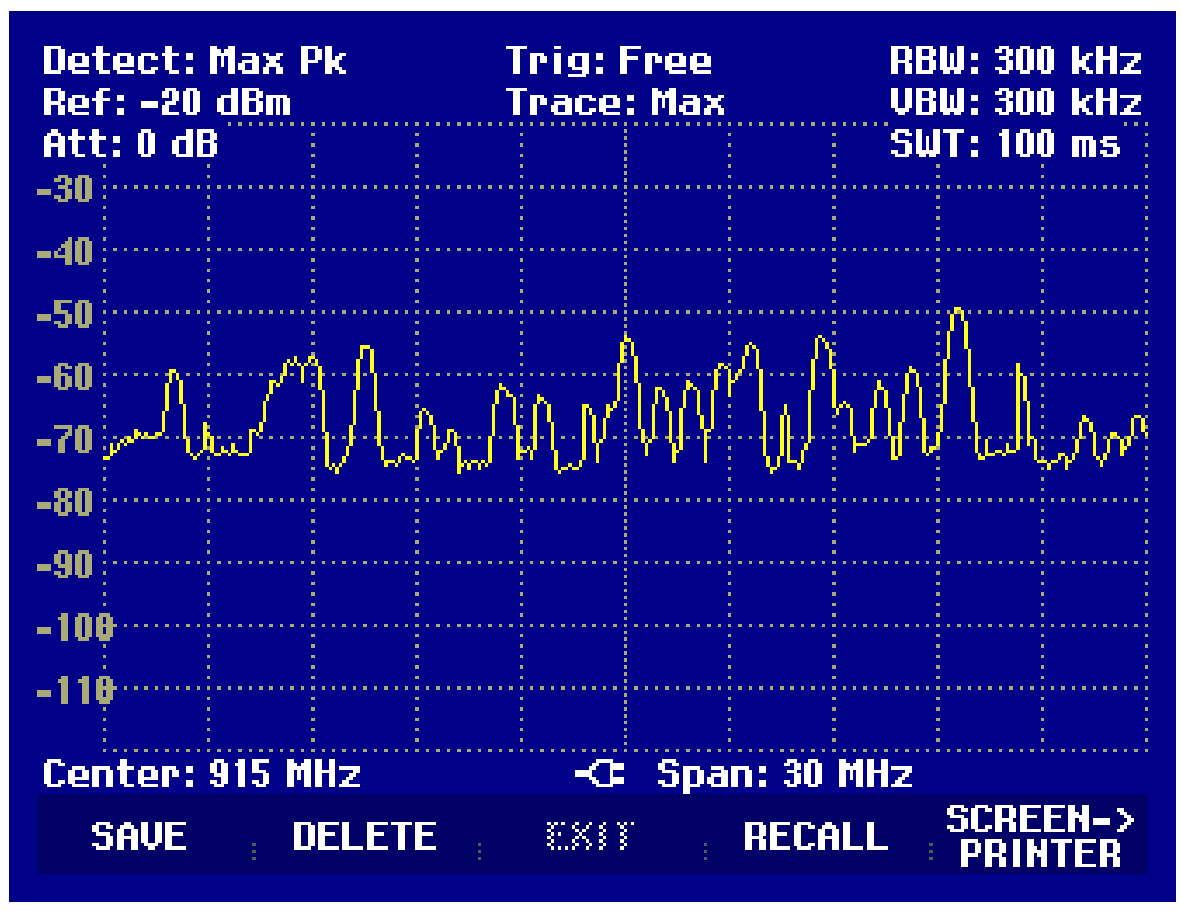

Figure 26: Spectrum centered at $915 \mathrm{MHz}$ and Span $30 \mathrm{MHz}$ 


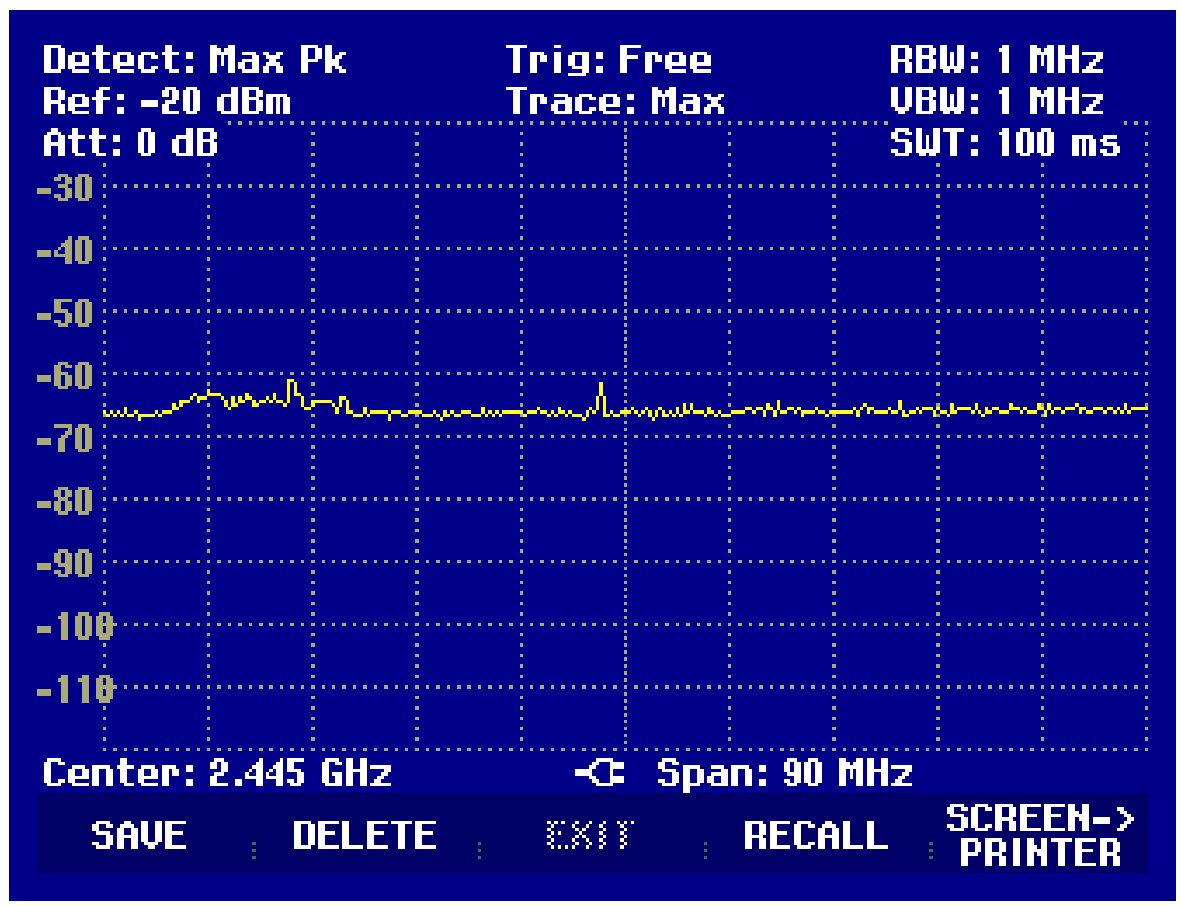

Figure 27: Spectrum centered at $2445 \mathrm{MHz}$ and Span $90 \mathrm{MHz}$

Location 9: Rolling Mill Pulpit

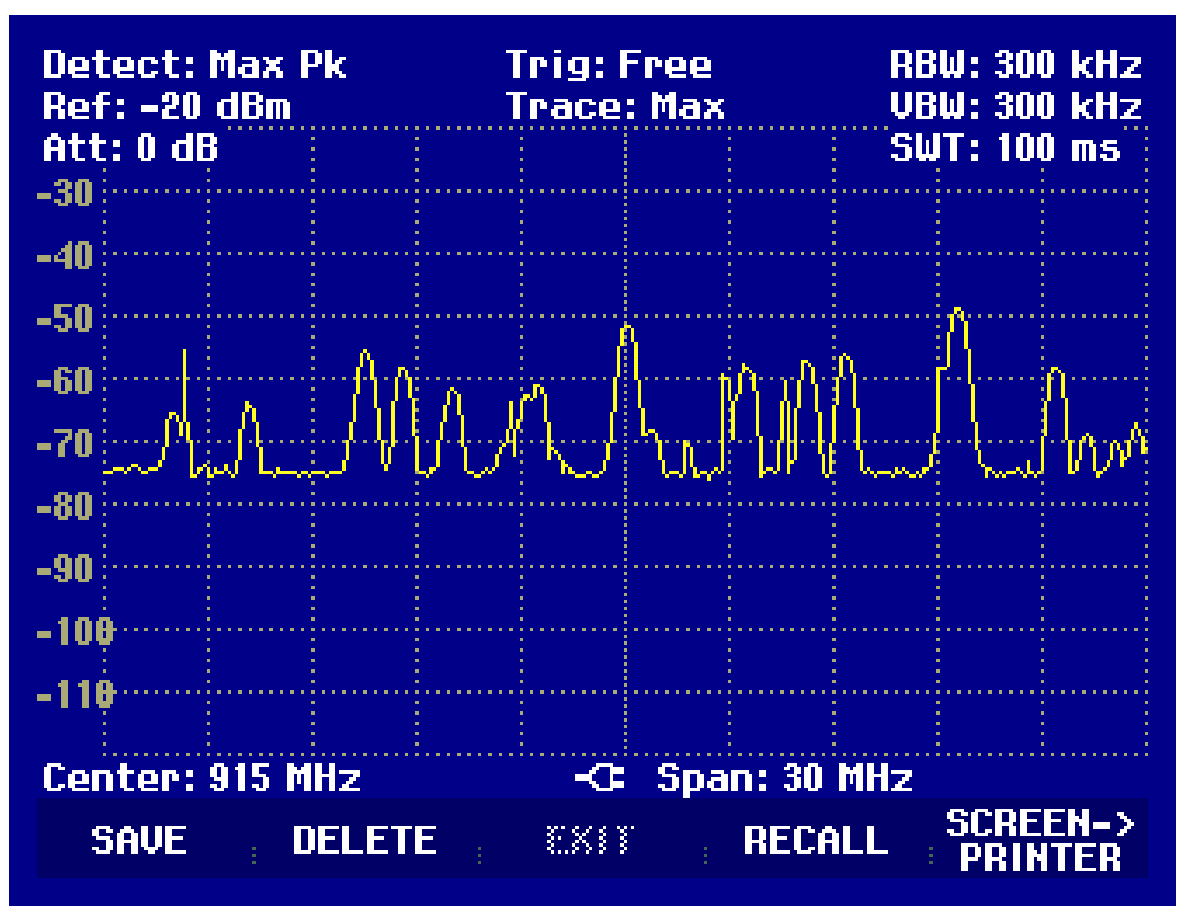

Figure 28: Spectrum centered at $915 \mathrm{MHz}$ and Span $30 \mathrm{MHz}$ 


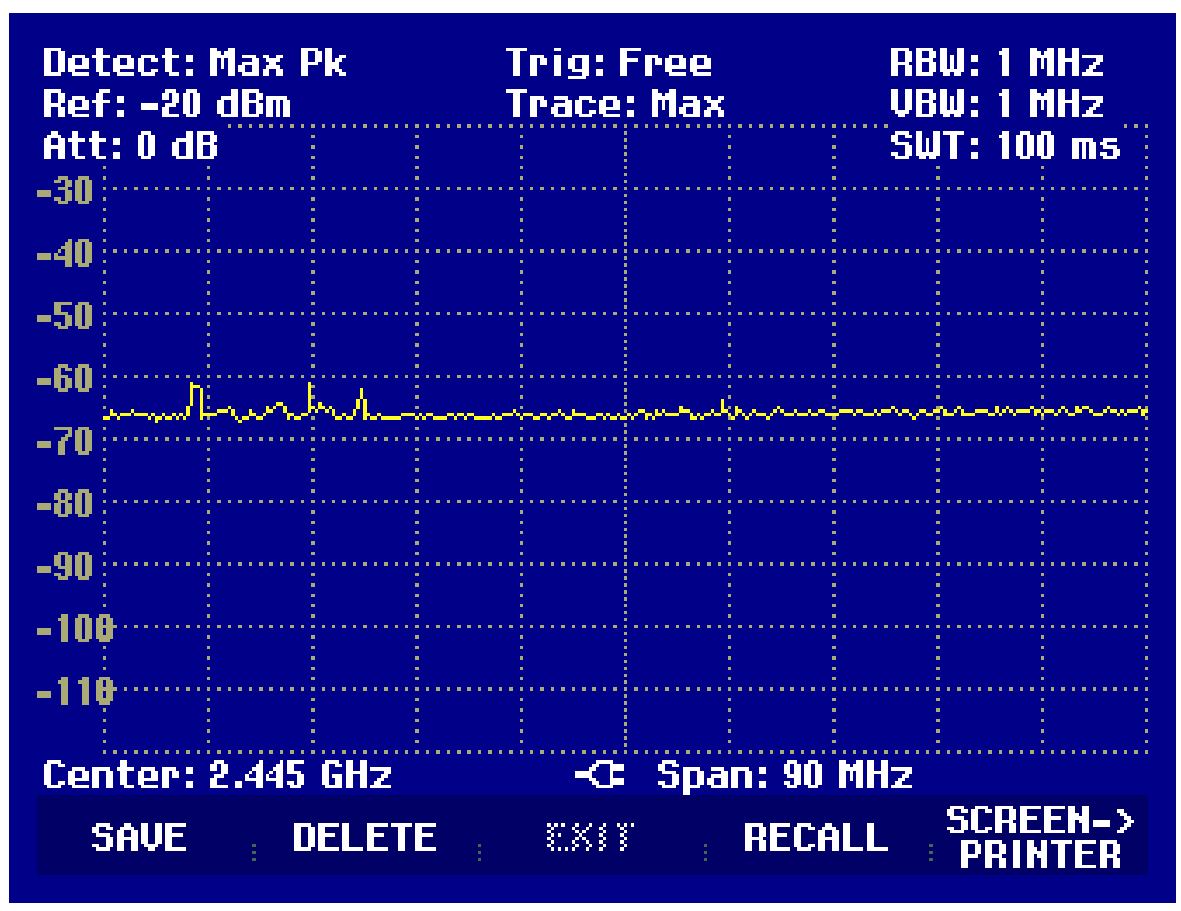

Figure 29: Spectrum centered at $2445 \mathrm{MHz}$ and Span $90 \mathrm{MHz}$ 


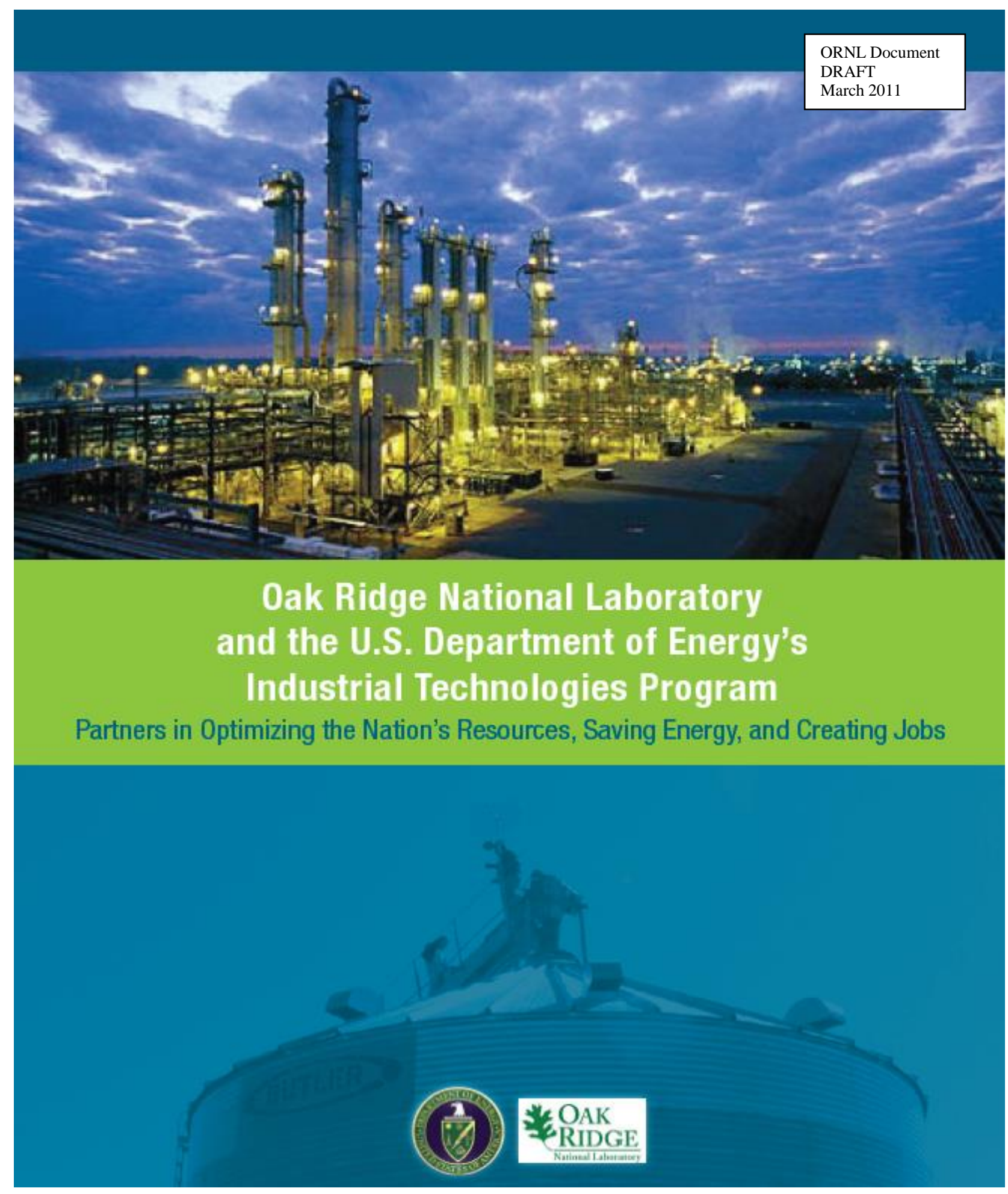


TEAM Work: Saving Energy

\section{DOE EERE GOal:}

Drive a $25 \%$ reduction

in industrial energy

intensity by 2017.

\title{
An Innovation-Rich Partnership
}

\author{
Oak Ridge National Laboratory and the \\ Industrial Technologies Program
}

The U.S. Department of Energy's (DOE)

Industrial Technologies Program (ITP) is widely recognized for its contribution to bringing the wireless revolution to the industrial marketplace. As part of the DOE/Energy Efficiency and Renewable Energy (EERE) office, ITP facilitated the creation of a broad vision and a jointly funded program for the development and deployment of the first market-ready products. The ITP wireless initiative has resulted in the creation of a number of start-up companies supplying hi-tech components and products for the new market, the inception of the Wireless Industrial Networking Alliance (WINA) that promotes industrial wireless applications, and ongoing efforts with the ISA100 standard (put forth by the International Society of Automation or ISA) for wireless industrial automation. In 2007, Executive Order 13423 mandated that Federal laboratory sites would set the standard for energy efficiency by improving their energy use by $30 \%$. This has led to several initiatives including showcasing industrial

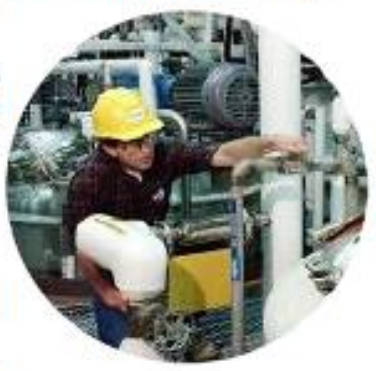
wireless technology applications.
Further, Oak Ridge National Laboratory (ORNL), as part of DOE's Transformational Energy Action Management (TEAM) initiative, is deploying wireless technology to improve efficiency of energy use at their site. This demonstrates the energy efficiency potential of their applications in the hope that such achievements will foster awareness and encourage other organizations-both public and private-to adopt these industrial energy conserving practices. This report highlights recent applications of industrial wireless technologies and ORNL. initiatives underway.

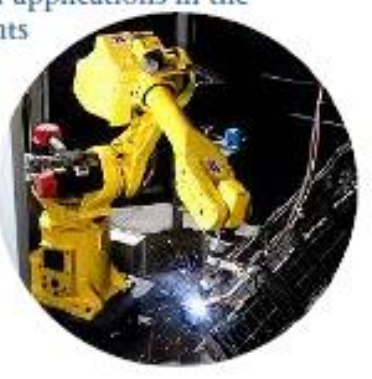

Since its inception, the dynamic, long-term relationship between ORNL and ITP has resulted in numerous technologies being enhanced and applied to various national needs aimed at improving national energy security, climate, environment, and economic competitiveness by transforming the way U.S. industry uses energy. ORNL and ITP continue the address such needs of the nation - and indeed the world.

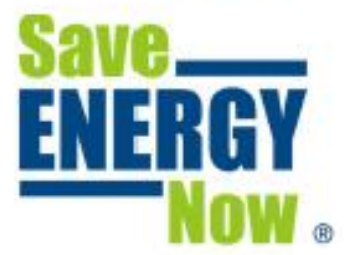


New Phase for ORNL's Sensors and Controls

\section{Going Wireless}

In the 1990s, ORNL began a focused activity in developing wireless technologies for the industrial sector. Numerous studies yielded reports that described the benefits that an "untethered, uncabled" data communication system could bring to the nation's industries' need for improvements in process and plant operations.

ORNL and ITP held a workshop on Industrial Wireless Technology during the summer of 2002 . Representatives from nearly 100 leading manufacturers and industrial organizations followed the ORNL-led discussions, attempting to ascertain the impediments to adopting wireless systems. Through this process, they realized the impact of improvements in plant operation and the associated economic benefits of increasing energy efficiency.

A visionary document was released post-workshop; a document whose core content has driven ITP and ORNL activities in creating a standards-based, secure wireless technology that allows the adopters to experience a direct savings of $15-40 \%$ (as compared to a wired equivalent) as well as improving plant operations.

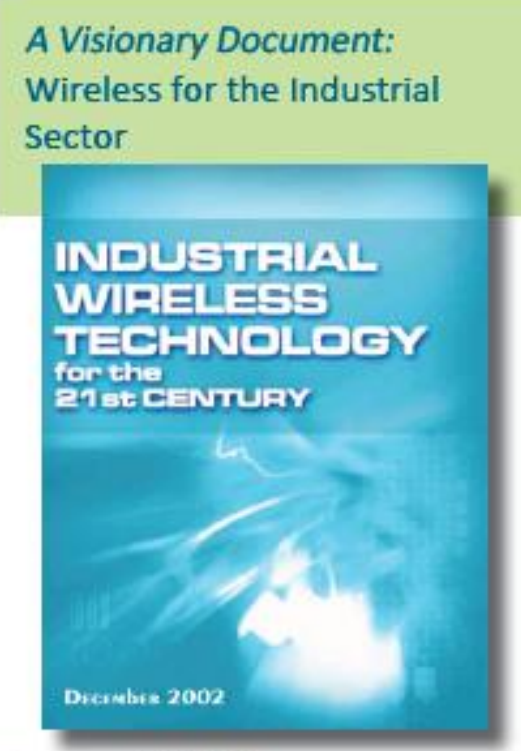

Early adopters of this wireless technology include industrial sites, residential and commercial buildings, transportation, and other components of the nation's critical infrastructure. The activities at ORNL, fostered by ITP, continue to this day in enhancing the crosscutting application for the wireless technologies developed in this partnership. The savings lie in energy efficiency, optimization of plant operations, creating and saving jobs, and more.

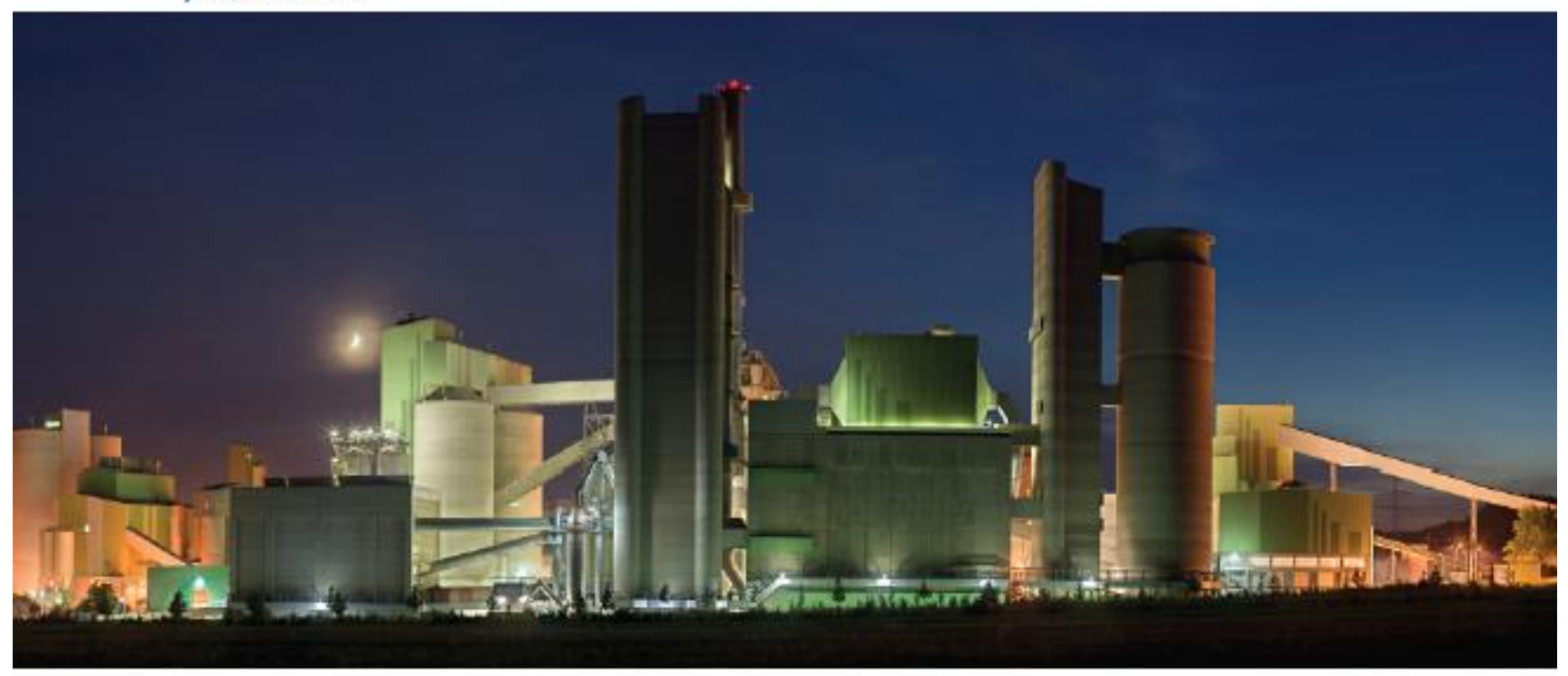

Partners in Optimizing the Nation's Resources, Saving Energy, and Creating Jobs 


\section{Expansion into Harsh Industrial Environments}

"The vision of wireless ... is the communications frontier of the next few decades" (Goldsmith, A.J., 2005).

ACEEE:

The American Council for an EnergyEfficient Economy is an independent, nomprofit organization dedicated to advancing energy efficiency as a means of promoting economic prosperity, energy security, and environmental protection.

\section{WINA $=$}

The Wireless Industrial Networking Alliance - WINA - is a nonprofit coalition of leading industry yendors and research institutions that serves as a trusted source of information by providing balanced coverage of industry issues across a wide range of manufacturing industries. Through its extensive network and educational outreach programs, WINA provides end users with current. timely and relevant information about the enhanced productivity, efficiency, and safety of industrial wireless applications.

\section{The Promise of Wireless}

Significant portions of this vision, the promise of wireless, already exist. Wireless networks already offer mobile communication (telephone and data) through cellular phone systems.

These networks are also used to provide Internet access in retail establishments for customers; have become the choice for home networking, including the new smart grid products for energy monitoring and efficiency; are being used as a replacement for wired networks in offices; and are even being deployed to make entire municipalities hot spots.

Wireless networking is even being deployed in challenging environments. The military is using wireless communication and sensors to identify a friend or foe, which minimizes the possibility of friendly fire incidents.

Other challenging environments include the use of wireless sensors for the detection and tracking of biological, chemical, and nuclear materials to ensure public safety and identify the proliferation of materials to potential non-friendly people or groups. These wireless networks permit a distributed control system with remote sensors and actuators and devices that are linked together via these wireless communications (Goldsmith, A.J., 2005).
Given the wide use and applications, where will the use of wireless expand to complete the vision?

The obvious answer for the expansion of the wireless vision is in the harsh environments of the industrial setting. Many of these facilities, as stated, face challenging communication environments, have facilities that make it difficult to install new wired sensor and control systems, require low power consumption, and have a need for the integration of both new and legacy equipment.

Wireless sensors and systems are being developed and deployed (although some are proprietary or require a single technology solution) to support applications in this environment.

The key to fulfilling the vision is to provide cost-effective products and applications that satisfy the industrial monitoring and control environment, and provide the owners and operators of these facilities with a competitive advantage through lower cost of production or increased product quality and improved employee safety. 

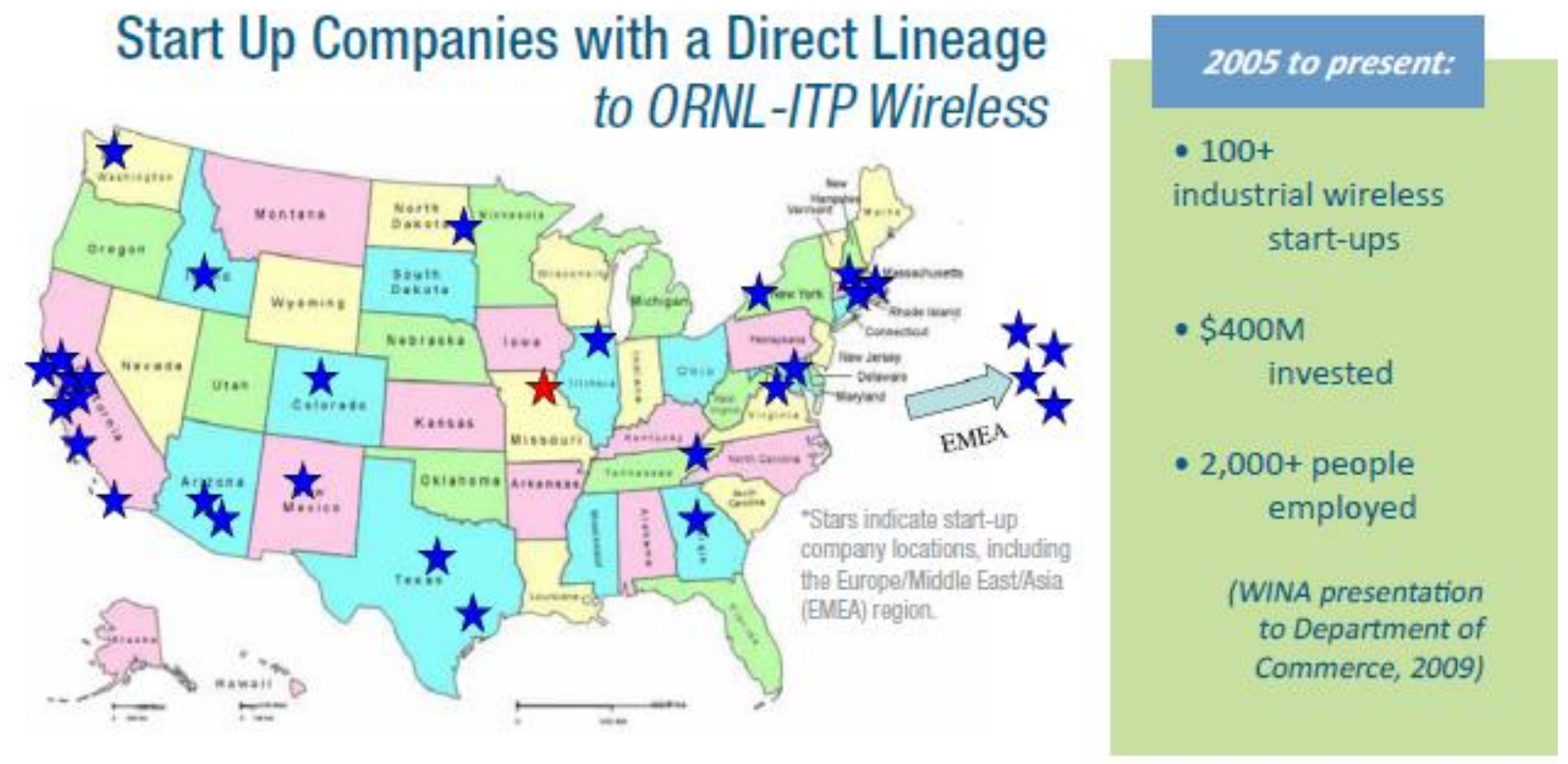

Public and Private Sectors:

Pushing the Industrial Wireless Revolution

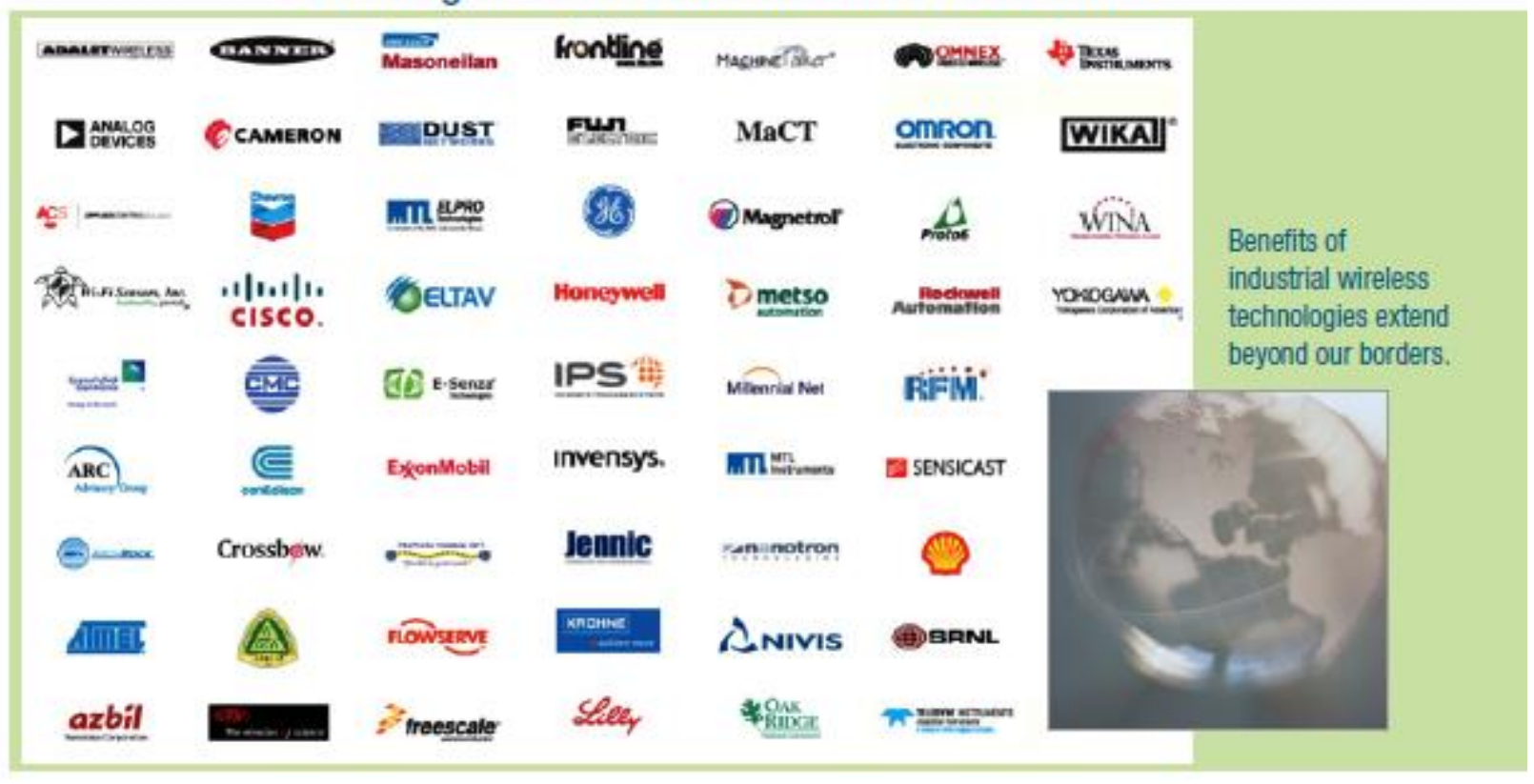




\section{“DOE, ORNL ... Please help us."}

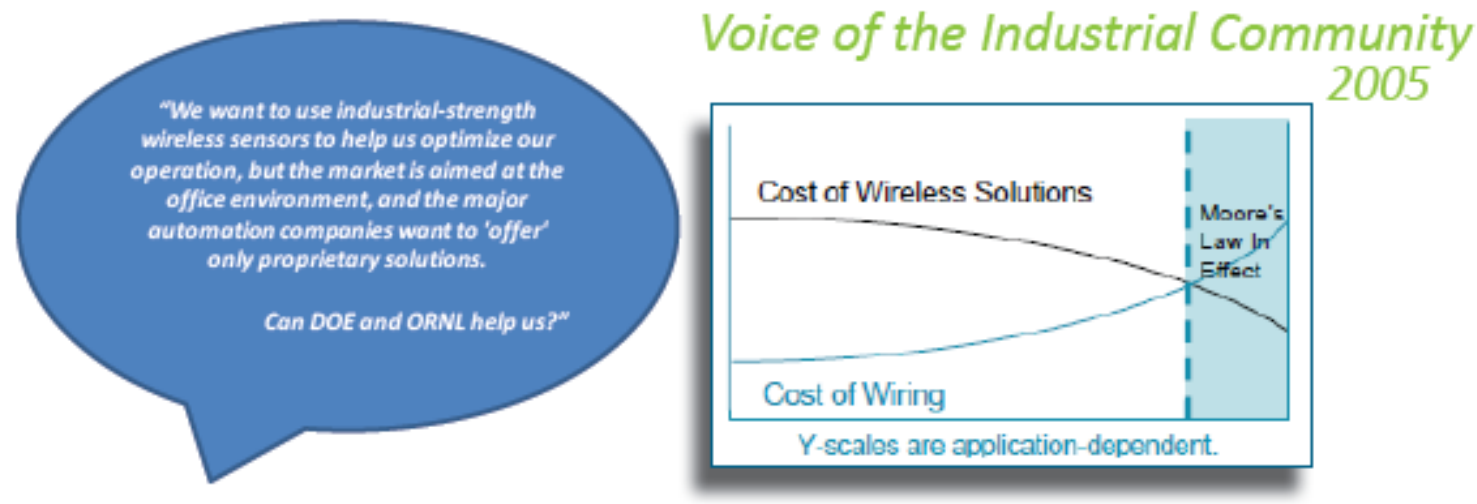

In today's industrial environment, systems and equipment must perform at levels thought impossible a decade ago. Global competition is forcing U.S. industry to continuously improve process operations, product quality, and productivity with fewer people than ever before. Production equipment must deliver unprecedented levels of reliability, availability, and maintainability as plant managers seek ways to reduce operational and support costs and to eliminate or minimize capital investments. In short, industry must invoke new measures to improve production performance and safety while minimizing costs and extending the operational life of new and aging equipment.

Wireless sensor systems can revolutionize industrial processing and help industry meet the demands of increased competition. Intelligent wireless sensors built for ubiquitous use in industrial environments will enable real-time data sharing throughout a facility to increase process control to improve product quality, increase yield, and reduce costs. In 1997, the President's advisers on science and technology asserted that the development of wireless sensors could improve production efficiency by $10 \%$ and reduce emissions by more than $25 \%$.

To realize these possibilities, the industrial community requested the development of a standard-or suite of interlocking standards - tailored to the industrial environment. In stepped ORNL and ITP to meet this need.

\section{Tailored to Industrial Environments}

Robust wireless systems will reliably perform missioncritical tasks in harsh industrial environments:

- Extremely high and low operating temperatures

- Strong vibrations

- Airborne contaminants

- Excessive

electromagnetic noise caused by large motors or conductors
- Exposure to harsh, corrosive chemicals - High humidity levels

- Potentially explosive situations

- Mobile and stationary metal equipment affecting transmission pathways

\section{Can a standard be developed?}

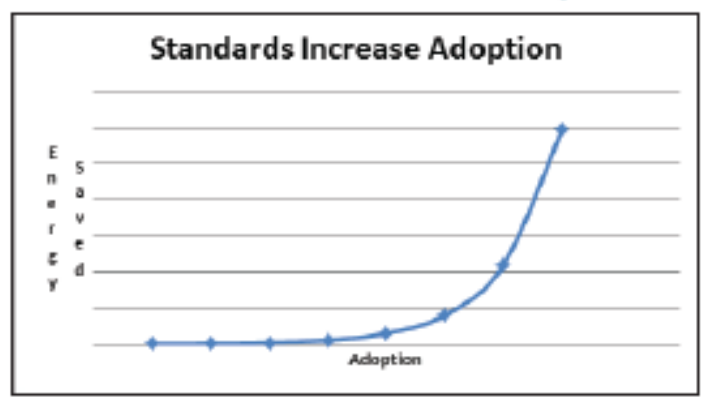


Why Standards are a Must

\section{Standards: Driving Wireless Sensor Technologies Toward Mainstream Adoption}

ITP's Impact on standards permits introduction of an entire suite of wireless products from many vendors supporting the "ubiquitous sensing" model in our vision.

\section{How a Standard Saves Money}

ISA's batch control standard illustrates how using a standard cuts costs. Food, pharmaceutical, and specialty chemical companies build factories with increasingly sophisticated computer-driven automation. The batch standard that ISA developed-ANSI/ ISA-S88.01-shaves as much as $30 \%$ off the cost of designing the system and software used in these plants. ANSI/ISA-S88.01 sets out a blueprint that engineers can use to make portions of the code interchangeable, which is less expensive than designing each piece from the ground up.

The savings extend beyond the facility's design, though. By using the batch standard, companies save as much as $10-15 \%$ off the typical cost of meeting Food and Drug Administration criteria for the reliability of automation equipment.

\section{How a Standard Saves Lives}

Other ISA standards focus on safety. ISA has developed standards for the performance requirements of toxic gas detectors, standards to keep electrical equipment from

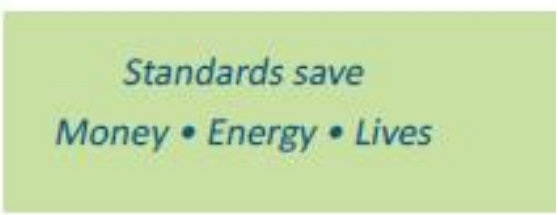

igniting flammable material, and standards to ensure safety at nuclear power plants.

Some ISA standards can help an entire industry combine cost savings and safety. The most popular ISA standard is ANSI/ISAS5.1, Instrumentation Symbols and Identification.

Developed in 1949 and most recently reaffirmed in 1992, these symbols are used in blueprints for everything from power plants to factories. If every contractor on a project knows the standard symbols, there are fewer communication problems that could lead to costly delays or safety problems.
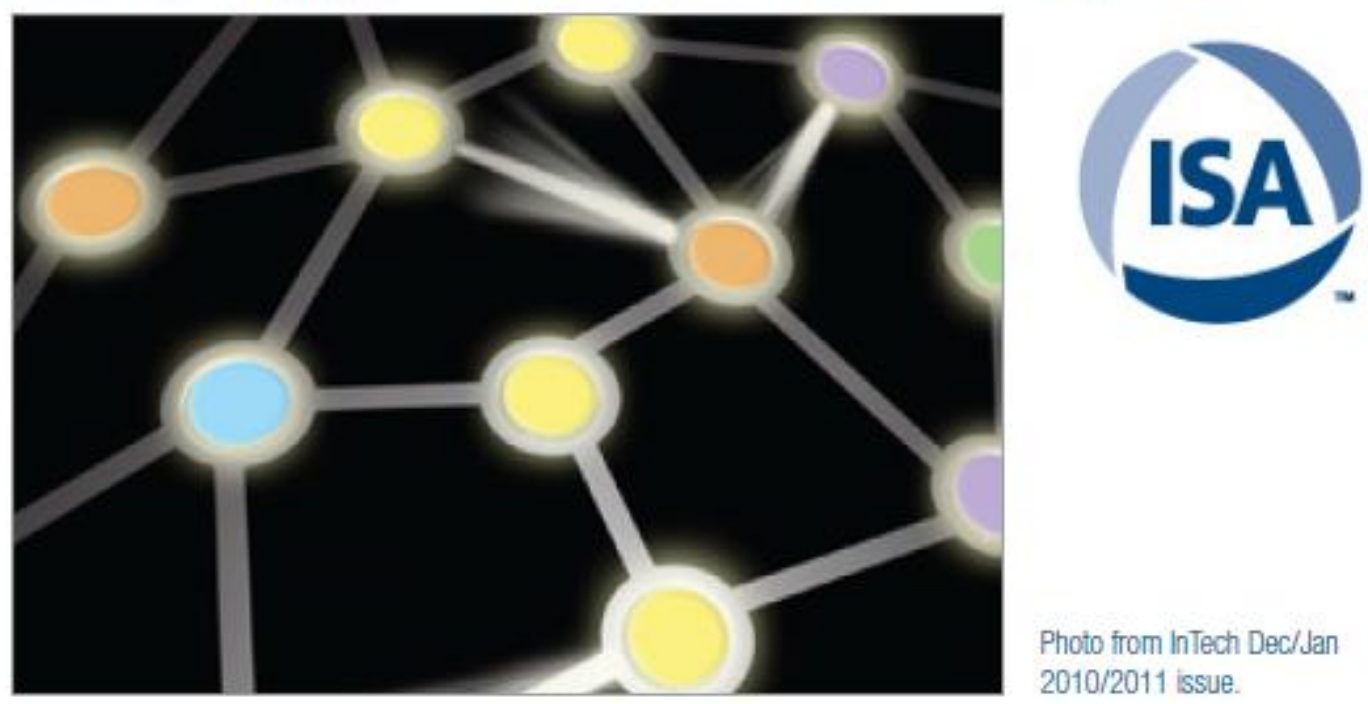

Photo from InTech Dec/Jan 2010/2011 issue. 


\section{Wireless Sensor Technologies Will Change Everything}

"We have garnered significant savings from utilizing wireless technology for measurement and point-to-point applications between systems. And, although we are just in the infancy of enabling the mobile operator and technician in our facility, the potential benefits in efficiency, safety, and environment are huge."

- Rob Brooks, process control supervisor, PPG Industries

\section{Aerial viaw of PPG in Lake Charles, Louisiana}

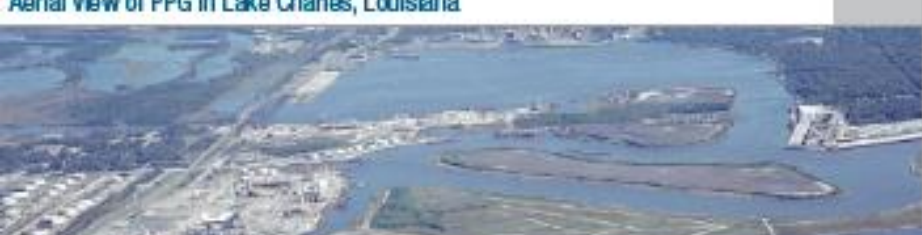

"The ISA100.11a mesh network was working in record time and was able to cover areas that were extremely expensive and challenging using other technologies. I was impressed."

- Didier Auber, Arkema Plant Manager

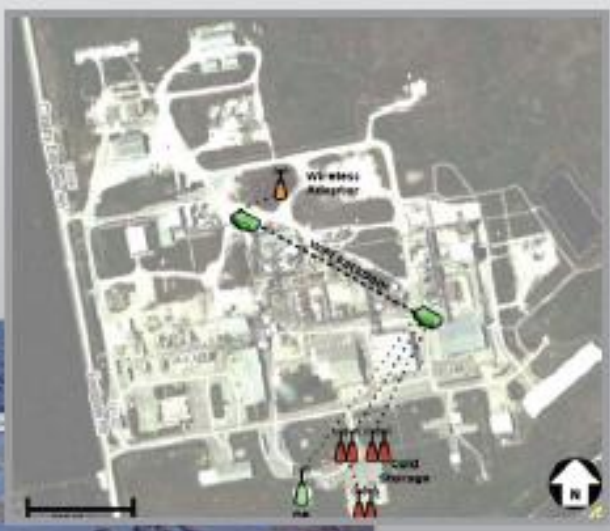

Industrial wreless deployment architacture at an Arkema chemical plant in Crosby, Texas 


\title{
Weathering the Storms: DOE and ORNL Aid in Hurricane Recovery
}

\author{
ExxonMobil, Baytown: Recovery After Hurricane Ike \\ A major oil company recounts their story of recovery \\ in a 2009 story published in InTech magazine.
}

\section{Wireless wins in dire straits}

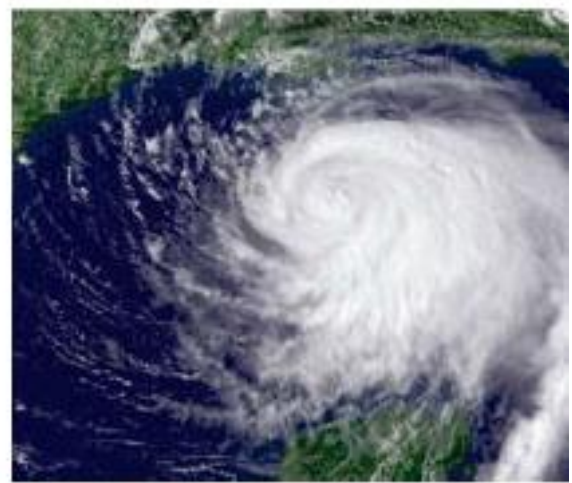

Bryan McVicker transferred to ExxonMobil's Beaumont, Tex., chemical plant in July 2008, but he got more than he had bargained for when Hurricane Ike tore through in September, leaving in its wake a broken levee, a plant flooded by 10 feet of water, and all electrical infrastructure destroyed. But after giving wireless a try (any port in a storm), McVicker and his team were sold on wireless benefits.

On Wednesday, at the Honeywell Users Group in Phoenix, McVicker, a Pyrolysis engineer at ExxonMobil, and Ken Routh, from the core engineering group at ExxonMobil Chemical in Baytown, Tex., gave their version of how they depended on wireless in this dire situation. "We were not allowed to go back to our offices or retrieve anything," McVicker said. "It was all trashed. While employees worked out of a hotel ballroom for several weeks, the entire organization had to restructure. When we returned to work, we found flares remained in service, but DCS and controls were lost. We were going to be in turnaround state for long time. We needed to make sure basic systems were in place to address potential hazards. I needed to make sure all core business units on site were adequately handling business preservation." Having no previous experience with wireless, McVicker was hoping to supplement operator founds, not replace them, as key process parameters during recovery.

Baytown Hefinery Under Water After Hurricane lke

Some of the challenges the company encountered included a weak infrastructure and no wiring, cabling, fiber optics, or permanent power. Also, they were limited in people because the instrument and electrician technicians and engineers were all focused on rebuilding the plant. So they contacted Honeywell to investigate wireless options. Within two days the vendor had mobilized technicians, and wireless stations came to the site. Within 12 days there was an initial startup with riskbased security and controls review and instruments limited to critical services.

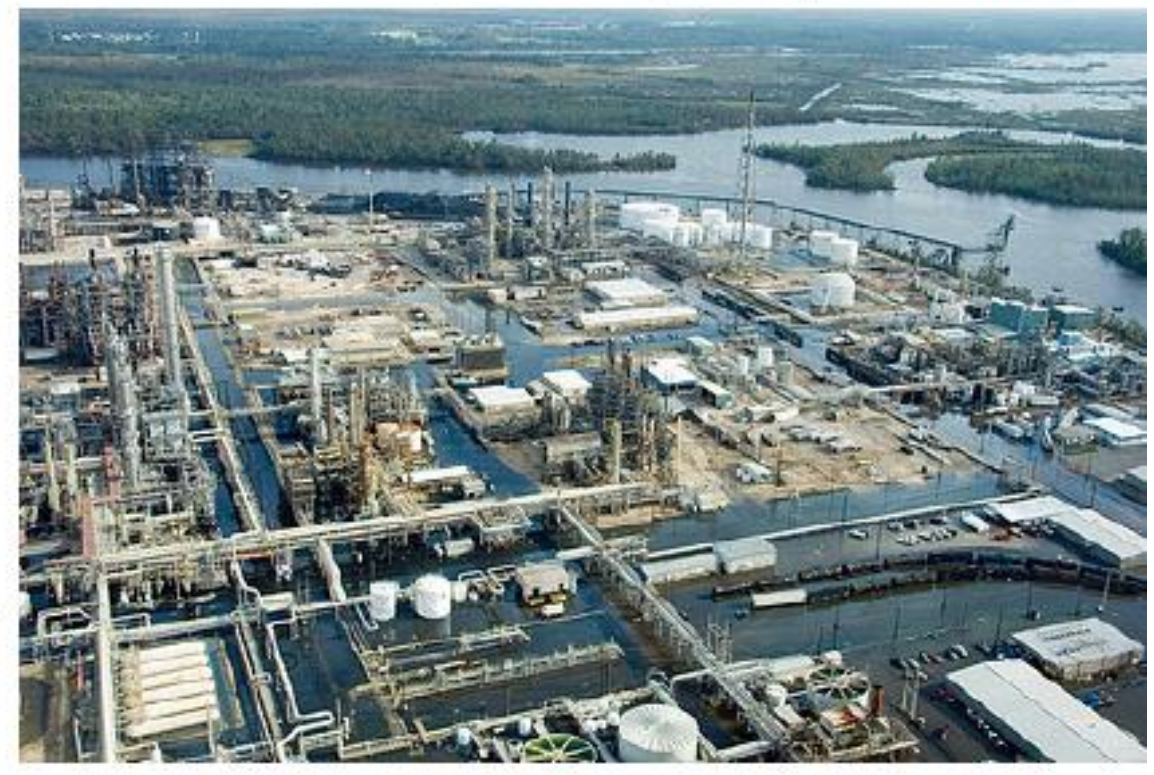


How Wireless Saved the Day

\section{Don't wait for a disaster to take wireless sensors for a test drive.}

As an expert called in to help, Routh's role was to provide global support as a technical generalist. "Some of the biggest specs we had were quick response, and we wanted a fix that could provide everything, " Routh said. "We needed one vendor who provides everything from transmitters to operator interface. We needed 802.11 Ethernet backbone wireless because we had no fiber optic or cable. At least at that time, the vendor we could identify quickly was Honeywell."

\section{Technical answers}

The Beaumont team implemented XYR 600 frequency hopping spread spectrum transmitters with five-second update rate. They initially installed nine transmitters, five-second update rate, with 17 transmitters ultimately installed. The fix also included IEEE 802.11a wireless backbone mesh, four multinodes initially installed, with a final total of five, all powered with a solar panel (temporarily powered initially with generators).

With an operator shelter 1100 feet away from the transmitters, the team used just a couple of PCs, with one seeing use as a OneWireless server that did all configuration and wireless networking setup. "One of our security controls stipulation was this network had to be completely standalone," Routh said. The only place to view the data was in front of a table in this operator shelter; there was no Wi-Fi capability. The interface was Honeywell HS Experion on a desktop PC.

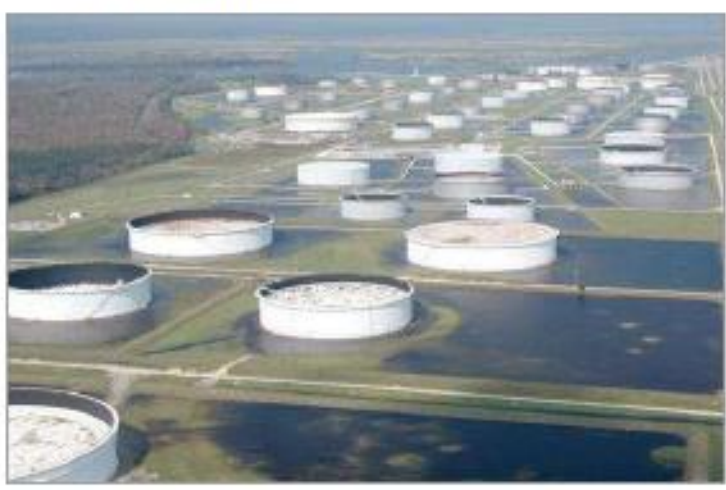

"The initial configuration had two multinodes close together because of the tall structures in the plant and concern about interference," McVicker said.

All in all, the wireless system made crucial device monitoring easier to use. It was staffed by console operators $24 / 7$, with instrument monitoring and historization, flare pilot thermocouples, cold flare vaporizer TIs and L.Is, and key utilities, such as firewater, potable water, natural gas, LP steam, and PIs.

Once the system was in service, operators immediately began using the system. They were able to troubleshoot systems with a proactive response to pre-alarms and alarms. At the end of the outage, data was collected. "The only thing we cared about was data appearing on the screen," Routh said. "We decided we needed technical data toward the end, so the Honeywell folks in the Houston area spent a lot of time helping us configure and troubleshoot; we monitored seven key performance parameters for three weeks at five-second intervals.

In the end, there was no problem in the system with errors or retries. During this time, one of the multinodes failed, where there were two close together. "We were worried about transmitters being able to get to multinodes," Routh said. "But we lost no data during that time."

-Ellen Fussell Policastro, InTech, 17 June 2009

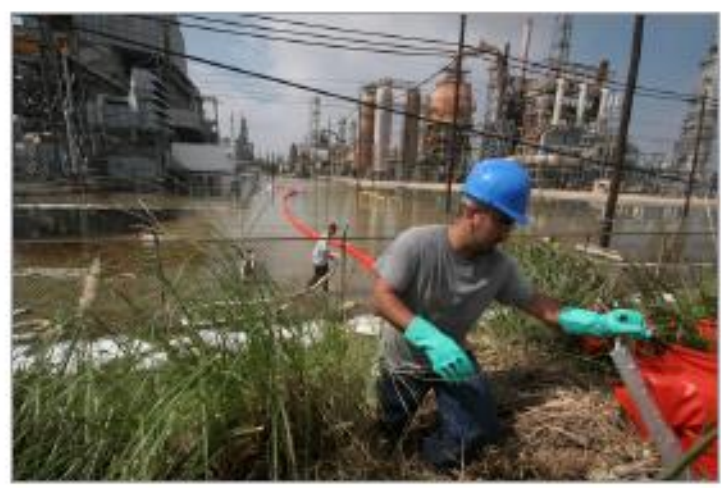




\section{Global Total Wireless Field Device Shipments By Scenario}

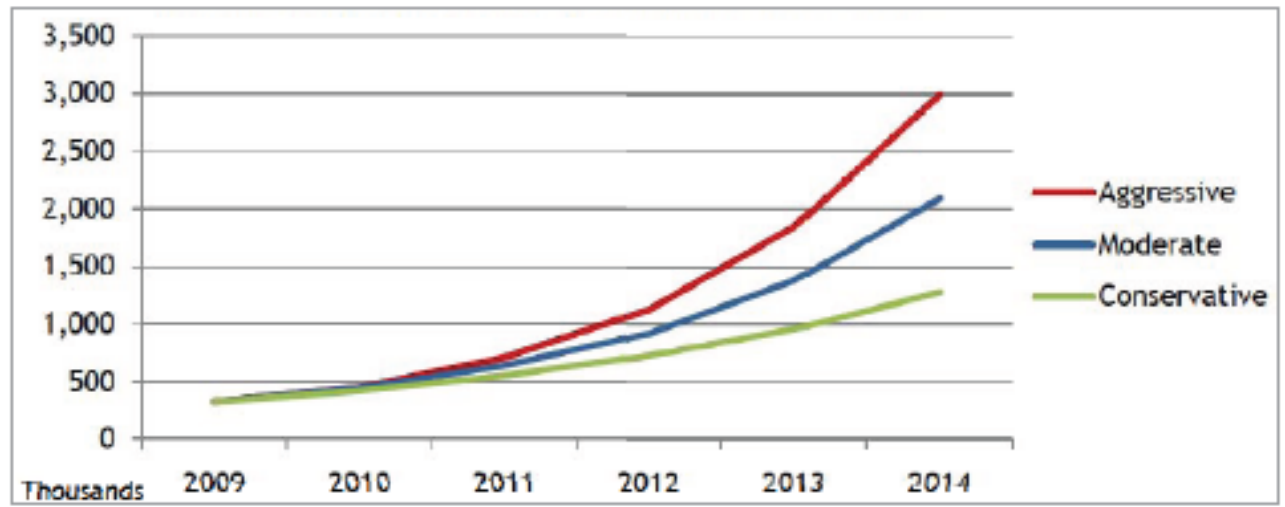

Forecasted market adoption of industrial wireless sensors and systems.

Industrial Wireless Sensor Network Units by Scenario

\begin{tabular}{|l|c|c|c|c|c|c|}
\hline Thousands & 2009 & 2010 & 2011 & 2012 & 2013 & 2014 \\
\hline Aggressive & 348 & 452 & 706 & 1,128 & 1,780 & 2,694 \\
\hline Moderate & 333 & 415 & 588 & 879 & 1,336 & 2,007 \\
\hline Conservative & 326 & 399 & 552 & 729 & 958 & 1,283 \\
\hline
\end{tabular}

\section{Saving Energy = Saving Jobs and Creating Jobs}

Industrial wireless is a technology sector that has blossomed over the past few years, employing thousands of individuals. As the ORNL/ITP-driven arena expands in the marketplace, the employment-and energy savings in the users' companies-is slated to rapidly increase. 


\section{Energy and Jobs}

Proven time after time, as the energy cost at a facility decreases, the funds may be redirected into increasing the number of jobs.

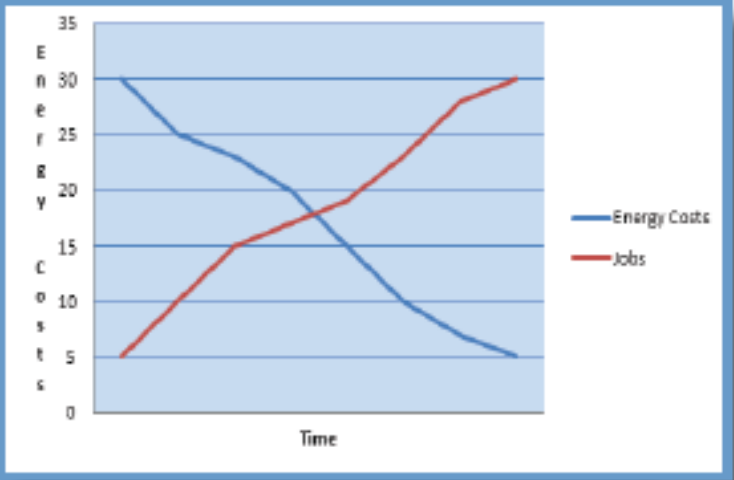

\section{Jobs versus Time}

As technologies develop and mature, the number of jobs within that technology increase and then plateau as the next technology is developed and deployed.

The wide variety of needs in an industrial facility-from voice to security to sensors and control-are mated to different wireless technologies.

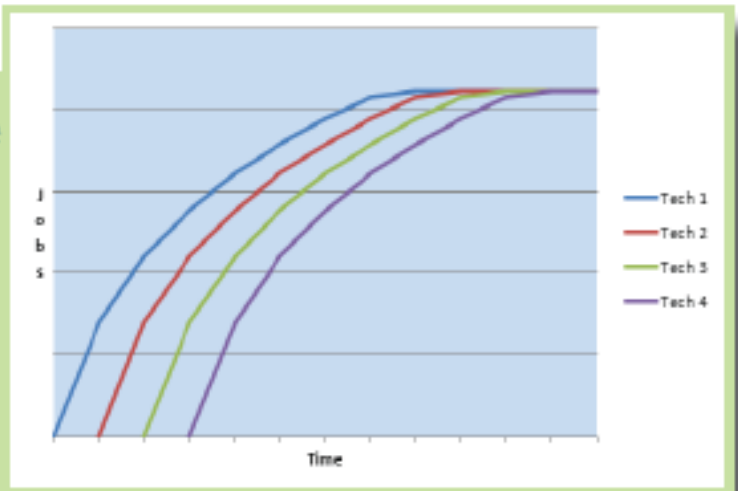

There are dozens of companies within each wireless sector that are delivering such technologies to the industrial arena.

\section{ENERTY}




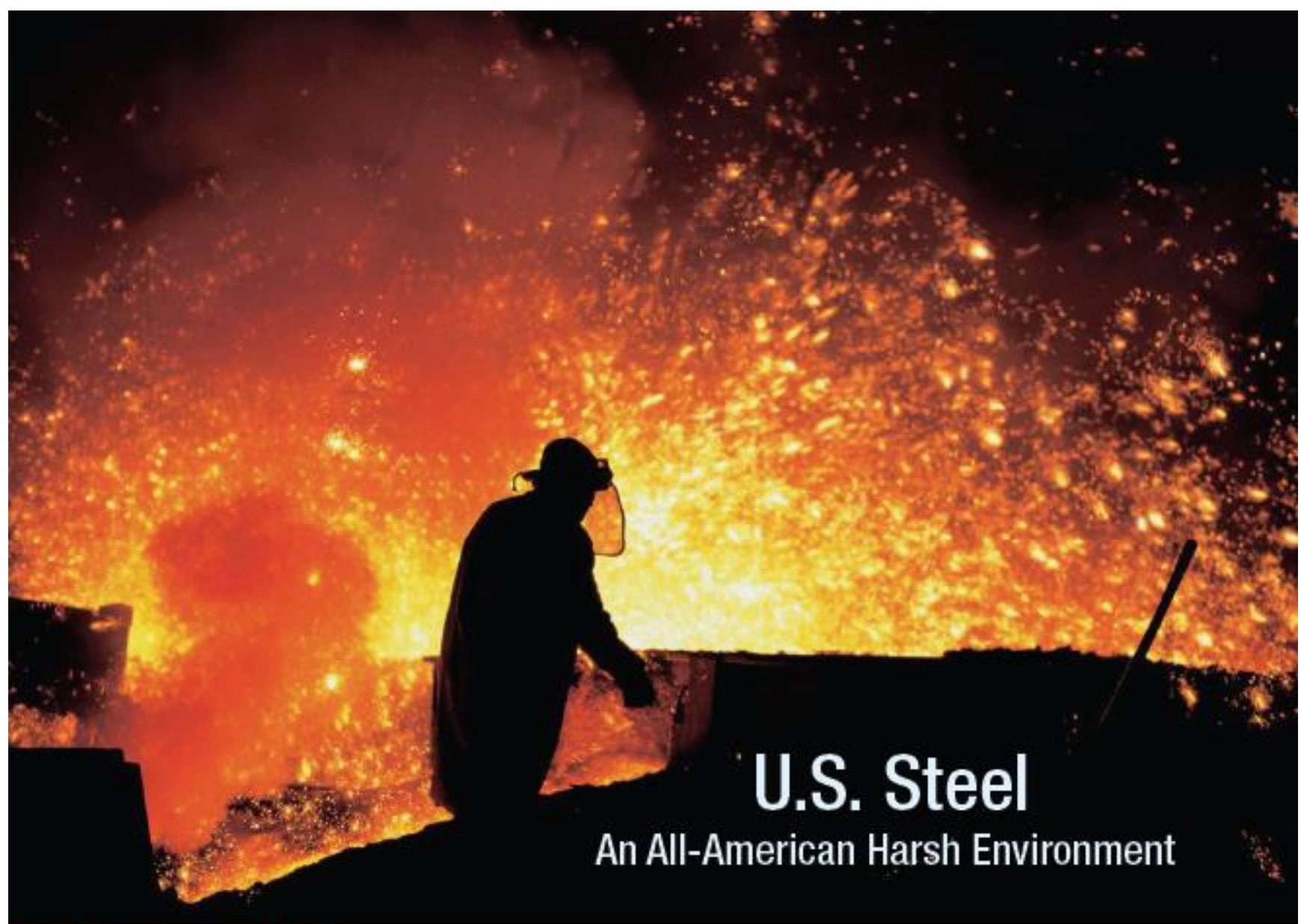

Obviously, an energy-intensive industry.

Steel is such an integral part of American life that its consumption reflects the strength of the domestic economy. Steel production is generally viewed as one of the most energy intensive sectors with images of blast furnaces and molten metal embedded in the general public's mind.

It's no secret that steel has taken a hard hit and has been struggling to recover ever since. U.S. Steel is no exception. Still, even in times of strife across the industry as a whole, it's companies like U.S. Steel who are taking the initiative to discover ways to save energy in efforts to better compete on a global level, while retaining jobs and even creating new positions.

Through the use of recycled materials, improvements in operational efficiency and adoption of new steel-making processes, the energy consumption industry-wide has declinded from around 45 (circa 1950) to 18 million Btu/ton (today) of shipped steel products. While impressive, the monotonically increasing cost of energy means that continued advances in efficient processes are required for employment retention and job creation in this industrial sector: 


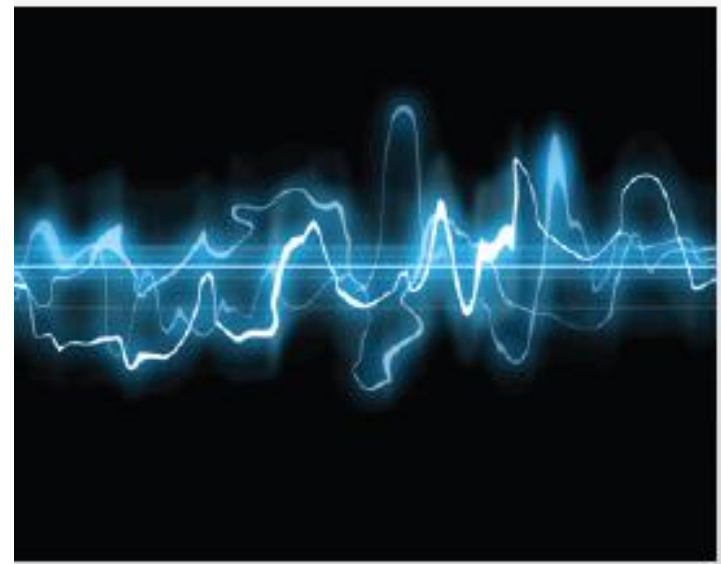

ORNL. studies conducted at U.S. Steel facilities reveal levels of repeating, impulse-based electromagnetic interference (EMI) that are unlike EMI signatures found in other industries.

\section{Canyons of Metal: Steel Facilities and Products}
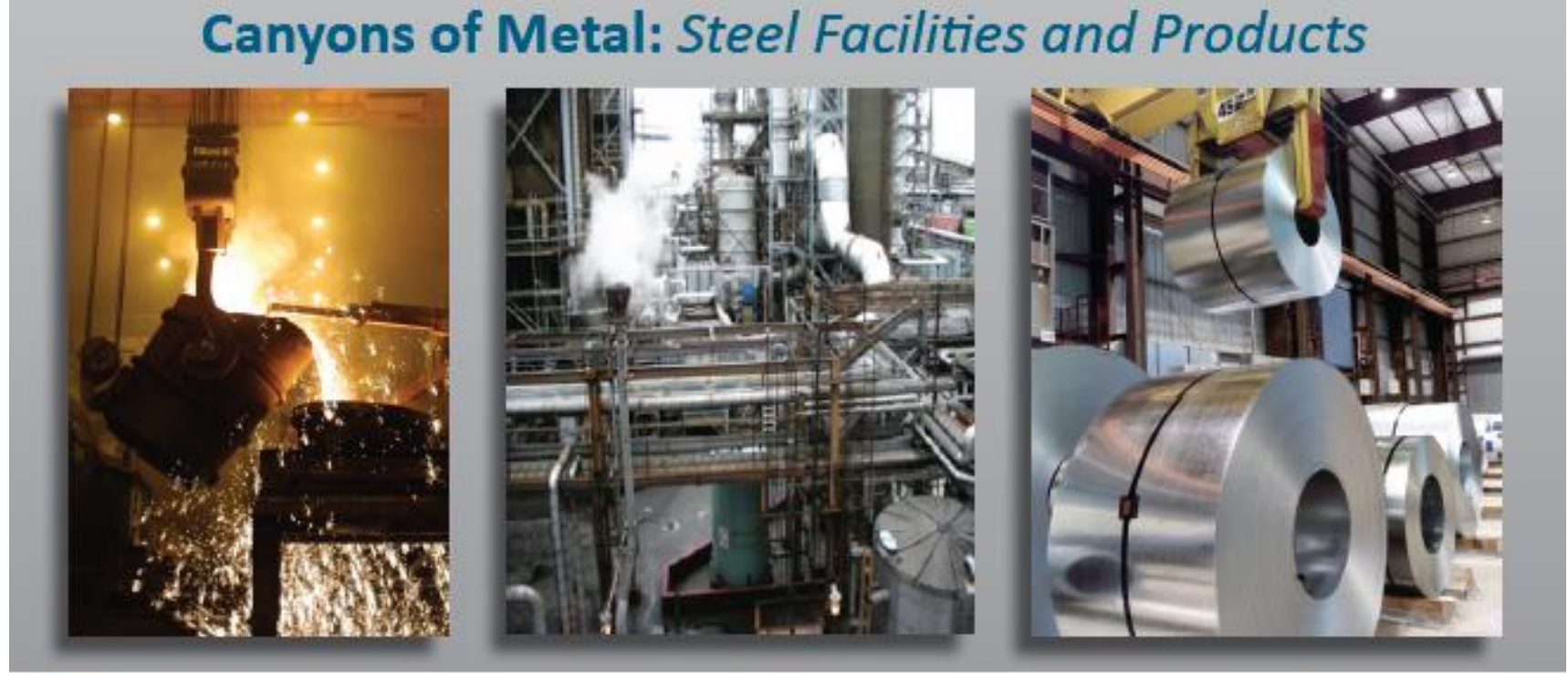

A DOE study reviewed various new technologies with the potential to impact steel industry energy consumption in the near future. Key among these new technologies: "Increased use of sensors in all operations to improve efficiency." There's no better place to put a wireless sensor network to the test than in a U.S. Steel facility. Implementation of wireless sensor technologies that operate well in a one of the harshest industrial environments is helping plant managers identify areas where changes can yield significant energy savings.

\section{Enter ORNL, ITP, and Wireless Sensor Networks}

The fabrication of steel involves sophisticated machines used in the processing of the constituent materials taking them from raw or recycled states into finished goods. ORNL studies conducted at U.S. Steel revealed levels of electromagnetic interference (EMI) that are unlike EMI signatures found in other industries. Through these investigations, ORNL has been able to share these findings with private and public sector concerns-including academia-leading to the development of robust wireless communications systems that are able to operate in such environments.

Even with the deployments of wireless sensor networks underway in a variety of industrial settings and plants, the high levels of EMI present in the factory-floor setting of a steel mill radiotransmission and communication performance are more challenged by the of the wireless communication channel, create packet-losses within the data exchange, and require more fobust protocols. To address these real-world concerns, ORNL and ITP embarked on a network deployment project in two steel mills. presence of metallic machinery. This can reduce the signal strength 


\section{Computational: Data Centers Applications Extend Outside Brick \& Mortar Industry}

Even with the positive impact of ITP's Technology Delivery, further advances through research and development are needed to meet national energy goals.

As our economy shifts from paper-based to digital information management, data centers - facilities that primarily contain electronic equipment used for data processing, data storage, and communications networking - have become common and essential to the functioning of business, communications, academic, and governmental systems. Data centers are found in nearly every sector of the economy: financial services, media, high-tech, universities, government institutions, and many others use and operate data centers to aid business processes, information management, and communications functions.

During the past five years, increasing demand for computer resources has led to significant growth in the number of data center servers, along with an estimated doubling in the energy used by these servers and the power and cooling infrastructure that supports them.

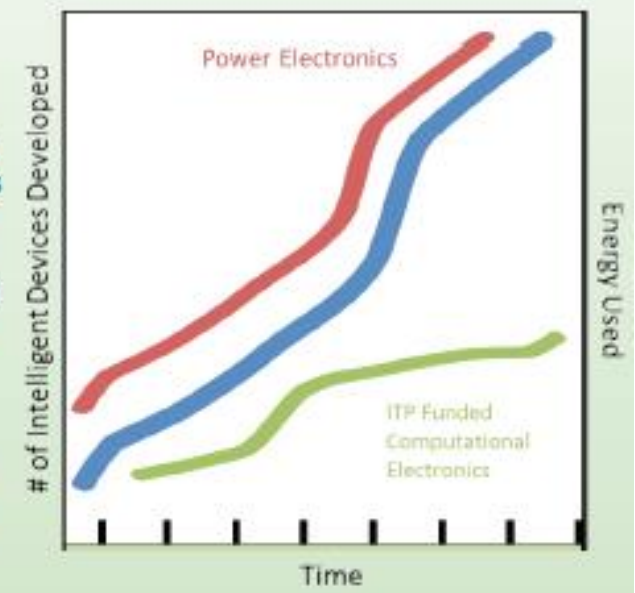

- Server-based data centers and telecommunications already use $3 \%$ of the nation's electricity; volume servers alone use 1\%

- Energy costs exceed the cost of data center IT equipment over its 3-5 year useful life

- Data center energy use is increasing by $12 \%$ annually

- Broadband is increasing telecom sector energy use 
"The problem is, with so many servers, how do we know what is going on with each one?"- Feng

Zhao, a principal researcher and manager with Microsoft Research's Networked Embedded Computing group
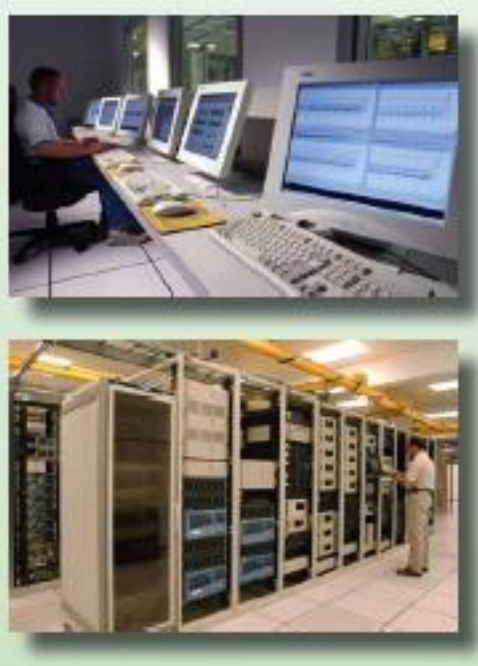

Important Implications of increases in energy use for data centers:

- Increased energy costs for business and government

- Increased emissions, Including greenhouse gases, from electricity generation

- increased strain on the existing power grid to meet the increased electricity demand

- Increased capltal costs for expansion of data center capacity and construction of new data centers
Demand for data center capacity is expected to grow at $10 \%$ CAGR over the next decade as businesses automate more processes, perform complex analytics, store more granular customer data, and employ rich media leading to an even larger need for energy and operational efficiency. For these reasons, there has been mounting interest in opportunities for energy efficiency in this sector.

But, how are these needs addressed?

\section{Enter ORNL, ITP, and Wireless Sensor Networks}

Consider the situation that Microsoft faced in monitoring one of its large data centers. "The problem is, with so many servers, how do we know what is going on with each one?" asked Feng Zhao, a principal researcher and manager with Microsoft Research's Networked Embedded Computing group.

Generally, it is difficult to determine such things as whether the airconditioning system is functioning correctly and whether any specific server is operating at a temperature beyond the safe threshold. Most data centers are large-averaging approximately 470,000 square feet in Microsoft's case-with multiple racks of servers. Air conditioning in each data center is set to ensure that the temperature never rises above a specified level around the servers at any rack in the large room. For every megawatt (MW) directed toward powering a data center, Zhao says, another $0.5-1 \mathrm{MW}$ is consumed in maintaining the proper temperature. Because it's impossible to know the temperature at any one location in the room, most companies simply turn the air conditioning up high.

Using wireless sensor networks whose design follows the recommended practices outline by ORNL and ITP, Microsoft has deployed a network of more than 700 sensors that provides for the tracking of temperatures on individual racks and shelves within its data centers wolldwide, thus allowing Microsoft to see the temperature or humidity around each rack of servers.

"If the temperature exceeds certain thresholds, the servers will suffer," Zhao says. "It would impact the performance of Microsoft's Internet services."

Similar stories of easily-deployable wireless sensors used in data centers around the nation highlight how the ORNL-ITP technology can improve energy efficiency, and even be used for software code optimization, while helping save energy, save money, and save and create jobs. 


\section{ORNL and ITP Sensors and Controls: Innovation is Contagious}

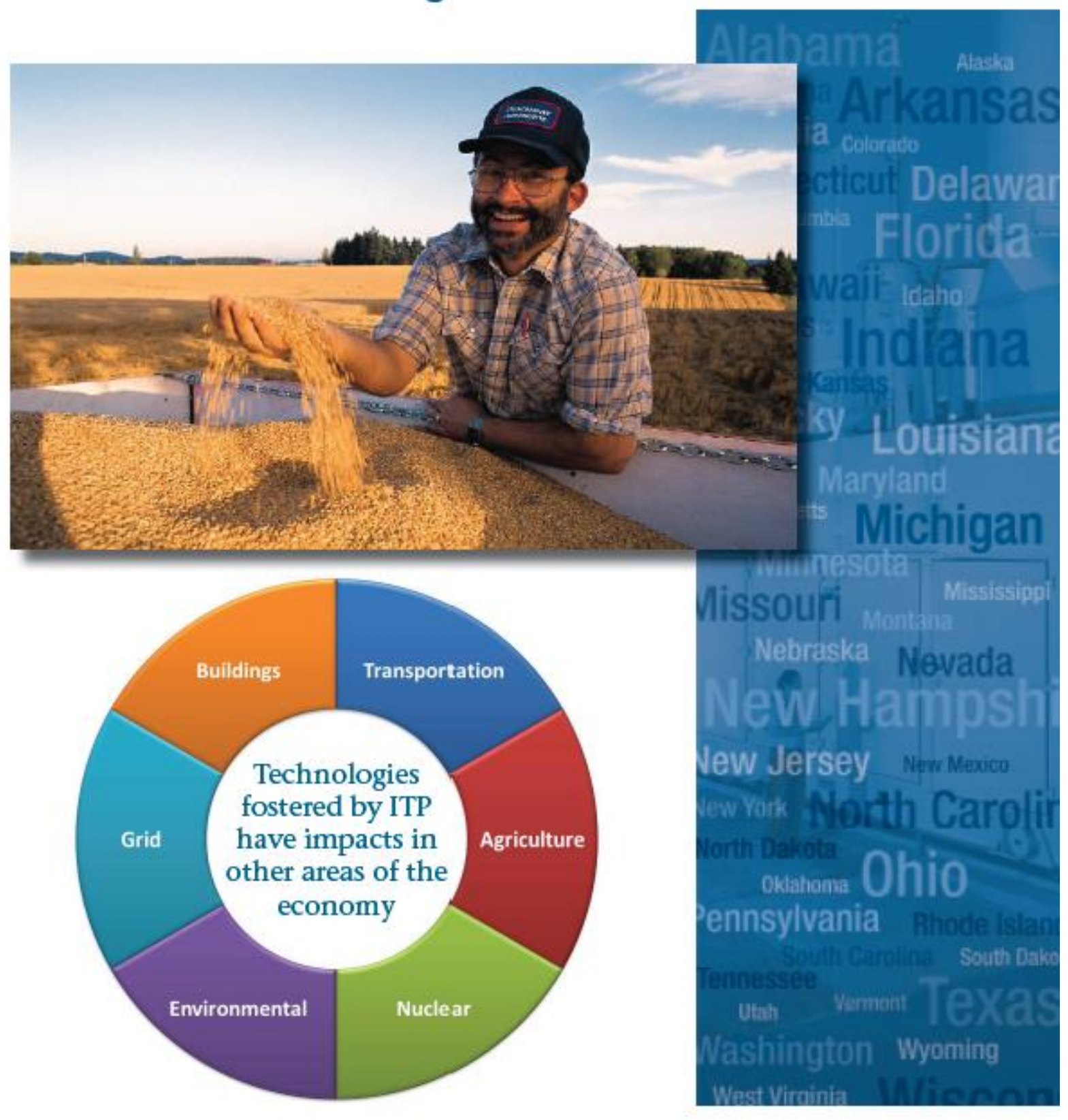



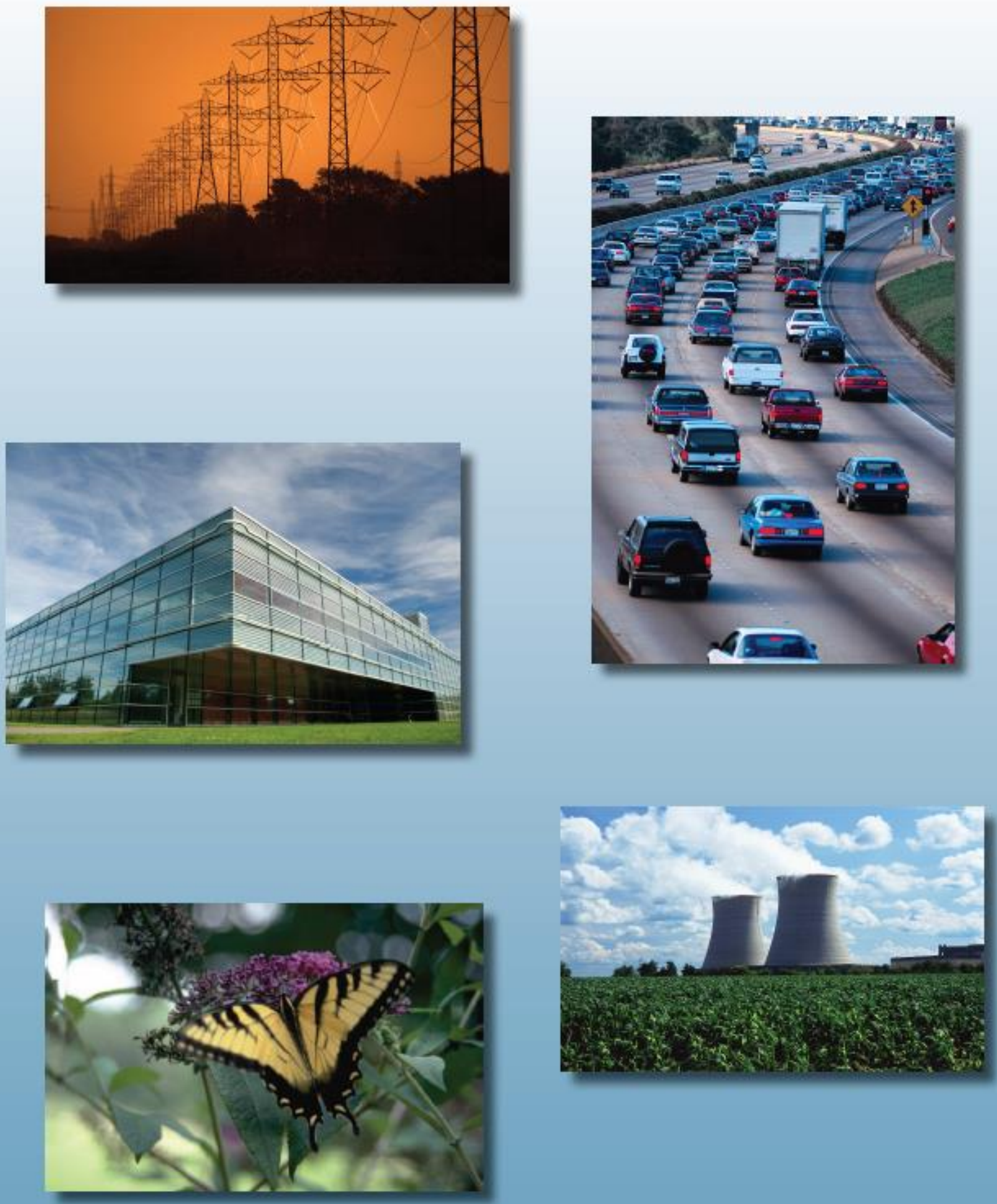


\section{For More Information}

\section{Contacts:}

Wayne Manges

Oak Ridge National Laboratory

Phone: (865) 574-5206

Email: mangesww@ornl.gov
Peter Fuhr

Oak Ridge National Laboratory

Phone: (865) 574-5206

Email: fuhrpl@ornl.gov

Web sites:

http://trustworthywireless.ornl.gov

http://www1.eere.energy.gov/industry

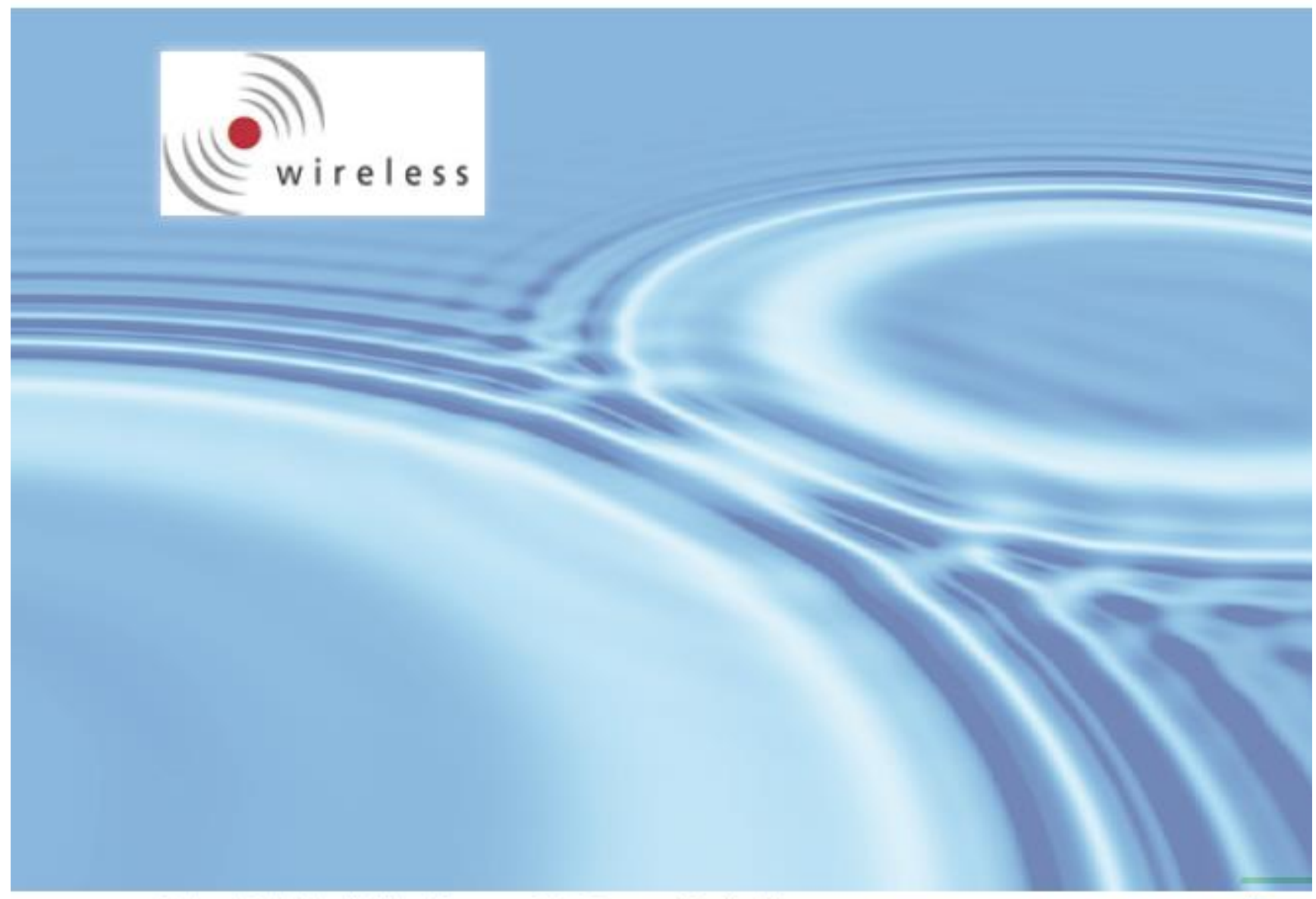

Partners in Optimizing the Nation's Resources, Saving Energy, and Creating Jobs 


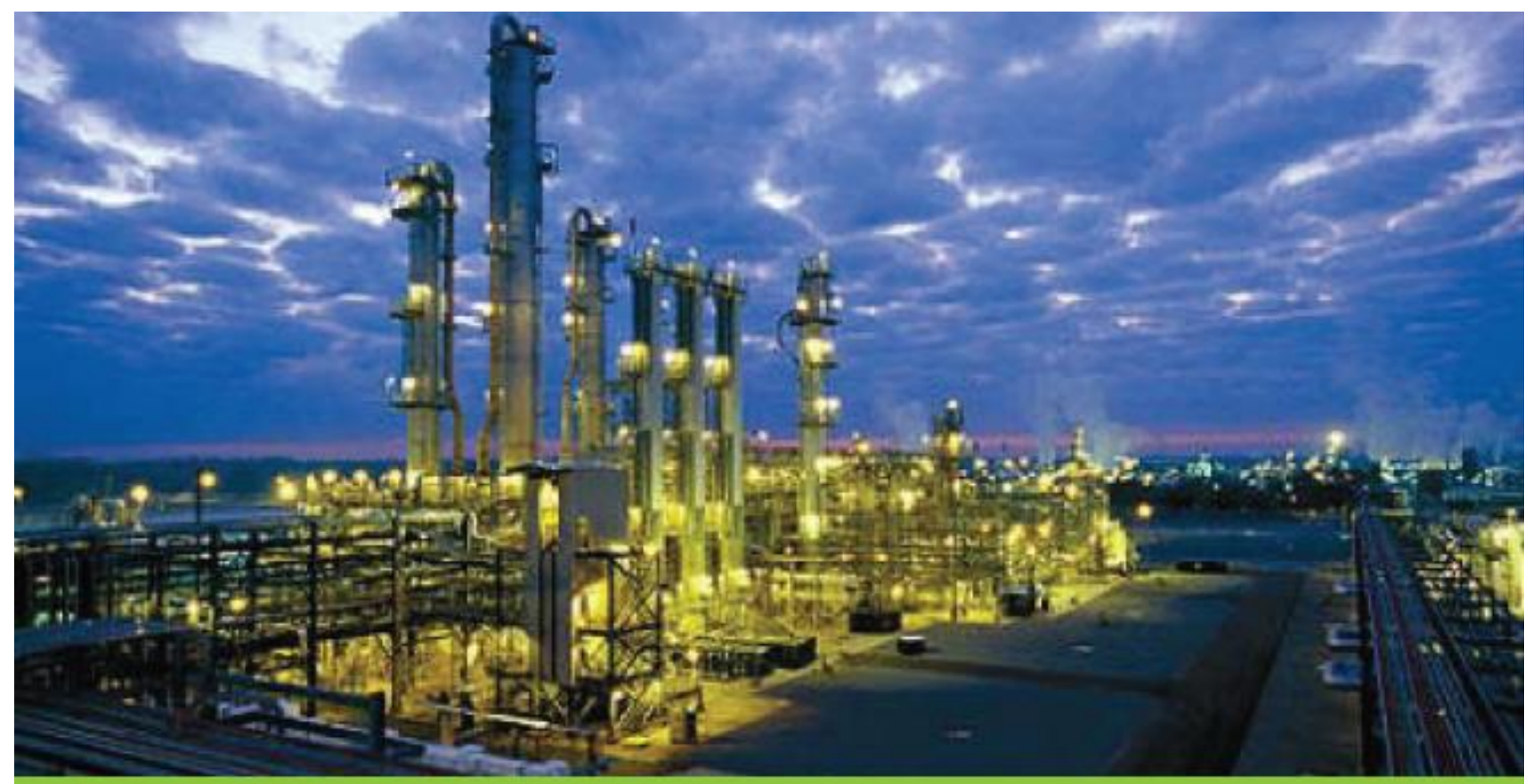

